\title{
PATRÍCIA MORATTI
}

\section{As relações de cuidados com bebês em creches: um olhar possível}

(Versão Corrigida)

Dissertação apresentada ao Instituto de

Psicologia da Universidade de São Paulo para a obtenção do título de Mestre em Psicologia.

Área de concentração: Psicologia Escolar e do Desenvolvimento Humano.

Orientadora: Prof. ${ }^{a}$ Dr. ${ }^{a}$ Eda Marconi Custódio 


\section{Moratti, Patrícia.}

As relações de cuidados com bebês em creches: um olhar possível / Patrícia Moratti; orientadora Eda Marconi Custódio. -- São Paulo, 2016. $255 \mathrm{f}$.

Dissertação (Mestrado - Programa de Pós-Graduação em Psicologia. Área de Concentração: Psicologia da Aprendizagem, do Desenvolvimento e da Personalidade) - Instituto de Psicologia da Universidade de São Paulo.

1. Bebês 2. Creches 3. Cuidados 4. Desenvolvimento infantil 5. Psicanálise I. Título. 
Nome: MORATTI, Patrícia

Título: As relações de cuidados com bebês em creches: um olhar possível

Dissertação apresentada ao Instituto de Psicologia da Universidade de São Paulo para a obtenção do título de Mestre em Psicologia.

Aprovado em:

Banca Examinadora

Prof. Dr. Instituição:

Julgamento: Assinatura:

Prof. Dr. Instituição:

Julgamento: Assinatura:

Prof. Dr. Instituição: Julgamento: Assinatura: 
Aos meus avós,

por todo amor e o

lugar nessa vida. 


\section{AGRADECIMENTOS}

confiança.

À professora Dr. ${ }^{a}$ Eda Marconi Custódio, minha orientadora, pela oportunidade e pela

À Prof. $^{\text {a }}$ Dr. $^{\text {a }}$ Maria Cristina Kupfer, pelas valiosas contribuições no exame de qualificação, pela interlocução firme, precisa e cuidadosa e, sobretudo, pelo convite para participação no grupo da pesquisa IRDI e o acolhimento às minhas inquietações.

À Prof. ${ }^{a}$ Dr. ${ }^{\text {a }}$ Kátia Pavani da Silva Gomes, pelas contribuições no exame de qualificação, pela leitura atenta e enriquecedora, por toda ajuda e sugestões apresentadas para o trabalho.

Aos professores das disciplinas da pós-graduação, por contribuírem com a expansão dos meus conhecimentos.

À Prof. ${ }^{a}$ Dr. ${ }^{a}$ Marie Claire Sekkel, por enriquecer a minha experiência com o brincar.

À Prof. ${ }^{a}$ Dr. ${ }^{a}$ Marlene Guirado, pelo desafio intelectual de pensar de modo diferente, pela interlocução marcada pelo tensionamento dos meus modos pensar a psicologia, pelas conversas sobre AID e psicanálise, pela atenção que demonstrou a minha formação e ao meu trabalho e, especialmente, pelas contribuições na etapa final.

Ao Dr. Ricardo Abrantes do Amaral (O chefe), por todo apoio e incentivo ao meu aperfeiçoamento profissional, pela compreensão nos momentos difíceis e, fundamentalmente, pelas concessões que fez para que este trabalho se concretizasse.

Às minhas mais que companheiras de trabalho, Aline, Bárbara e Elaine, por não apenas cobrirem, mas, também, suportarem minhas ausências nas atividades diárias e na equipe. Por suas presenças solidárias e cuidadosas, pelo incentivo e, especialmente, por todo carinho e apoio nos momentos difíceis.

As colegas do grupo de pesquisa IRDI nas creches, pelas conversas e trocas, pelas parcerias, o interesse e incentivo a esse trabalho.

Ao grupo das segundas, Ana, Geovana, Mariza, Marlene e Sueli pela disponibilidade e interesse com que compartilharam a leitura e discussão de um fragmento do meu trabalho, agradeço as contribuições.

Ao querido amigo, Claudinei Affonso, primeiramente, pela importância em minha vida! Agradeço as conversas e contribuições, quando o texto não passava de um projeto, pelo 
acolhimento as minhas dúvidas, pela leitura e as contribuições com o texto. Especialmente, pelo olhar cuidadoso, a compreensão e apoio no momento de adversidade.

À amiga Viviane, querida companheira nessa vida, por sua amizade e carinho.

À Odete, pelos passos ritmados, pelo acompanhamento cuidadoso, firme e seguro.

À Dr. ${ }^{\mathrm{a}}$ Luciana Gomes Tarelho, por todos os cuidados... sonhar!

Ao meu pai, pelos meus primeiros livros de histórias e poesias, com quem aprendi a

À minha mãe, por todos os cuidados, pela amorosidade e admiração, por me ensinar a superar.

Ao meu irmão mais querido, primeiro amigo nessa vida, companheiro de todas as horas, pela presença que faz do mundo um lugar melhor e a minha vida mais feliz, por todo interesse e reconhecimento que demonstra por mim e por aquilo que faço.

Ao Renato, por seu amor e companheirismo nessa vida!

Às secretárias, Sandra e Olívia, por toda ajuda e as orientações.

E aos funcionários da Biblioteca Dante Moreira Leite, por todo auxílio durante os três anos, pela disponibilidade, atenção e pelos carinhos: balinhas, empréstimo de extensões, as cadeiras confortáveis, a vigilância com meus pertences e as conversas amistosas. 
"Feliz é a criança que, de um modo geral, tem liberdade para enfrentar no dia-a-dia as experiências das novas coisas que vão ficando ao alcance de sua crescente capacidade".

Donald Woods Winnicott 


\section{RESUMO}

MORATTI, Patrícia. As relações de cuidados com bebês em creches: Um olhar possível. 255 f. Dissertação (Mestrado em Psicologia) - Instituto de Psicologia, Universidade de São Paulo, São Paulo, 2016.

Este trabalho tem como objetivo analisar as relações de cuidados que se estabelecem entre as profissionais e os bebês em creches para discutir como esse ambiente contribui para o desenvolvimento psíquico dessas crianças. As observações das relações de cuidados com os bebês foram realizadas durante acompanhamento das profissionais em serviço nas creches. Esse acompanhamento oportunizou o conhecimento das rotinas de cuidados com as crianças e, a partir disso, algumas intervenções foram realizadas tanto com os bebês quanto com as profissionais para compreensão das relações de cuidados que se estabeleciam entre eles. Buscou-se a partir de um referencial psicanalítico, alguns conceitos para a leitura das relações de cuidados com os bebês, destacando como operadores de leitura, particularmente, aqueles que tratam da relação de cuidados e seus aspectos constituintes como facilitadores do desenvolvimento psíquico de bebês. Tendo como foco as relações de cuidados analisou-se cenas que mostram fragmentos dessas relações de cuidados entre as profissionais e os bebês. Por fim, discutiu-se essas relações de cuidados, descrevendo como aconteciam e, como as ações interventivas realizadas se desdobraram no ambiente das creches, mostrando os efeitos que se produziram nas relações de cuidados com os bebês. Refletiu-se como ações simples podem criar cuidados possíveis, promovendo o desenvolvimento psíquico dos bebês, ao mesmo passo, apoiar as profissionais na direção da realização dos cuidados com os bebês em creches.

Palavras-Chave: Bebês. Creches. Cuidados na primeira infância. Desenvolvimento infantil. Psicanálise. 


\begin{abstract}
MORATTI, Patrícia. The relationships of care with babies in day cares: A possible approach. 255 f. Dissertação (Mestrado em Psicologia) - Instituto de Psicologia, Universidade de São Paulo, São Paulo, 2016.

This study has the objective to analyse the relations of cares established between professionals and babies in day cares, in order to discuss how this environment contributes to the psychic development of these children. The observations of these relations were made while following the routine of professionals working in day cares. This monitoring enabled the knowledge of the routines of cares with the children, and through that, some interventions were made with the babies and the professions in order to understand the relations of cares between them. Concepts of psychoanalytical reference were used for interpretations, operationalized particularly by those that deal with the relations of care and their constitutive aspect of facilitating the psychic development of babies. With focus on relations of cares, we have analysed scenes with fragments of these relations between professionals and babies. At last, we discussed these relations by describing how they occurred and how the interventions unfold in the day care environment, showing the effects produced in the relations of cares with the babies. We have thus reflected upon how simple actions can create possible cares, promoting the psychic development of the babies, and the support of professionals to promote cares with babies in day cares.
\end{abstract}

Key words: Babies. Day cares. Early childhood care. Child development. Psychoanalyses. 


\section{SUMÁRIO}

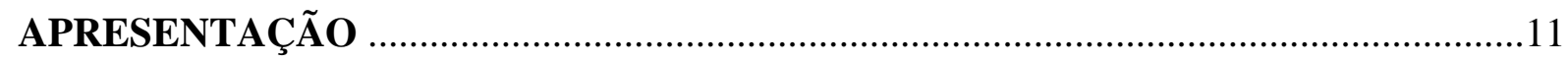

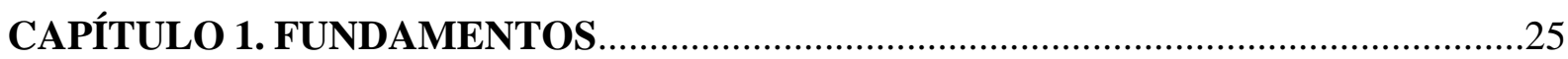

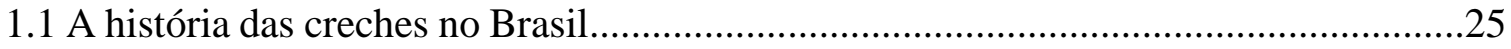

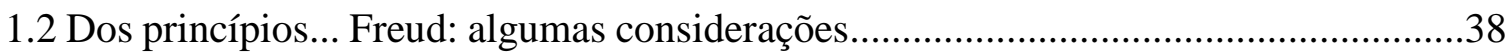

$1.3 \mathrm{O}$ desenvolvimento do bebê no primeiro ano de vida na perspectiva de Spitz...............44

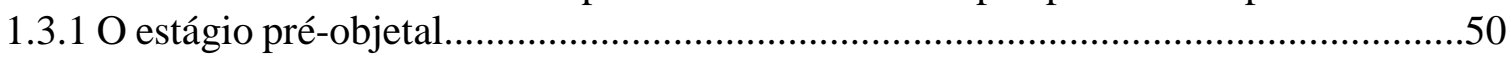

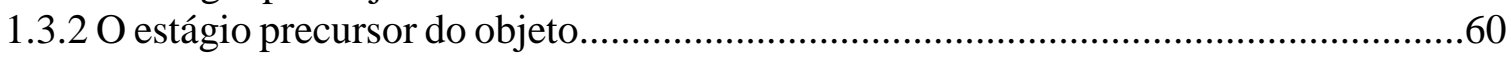

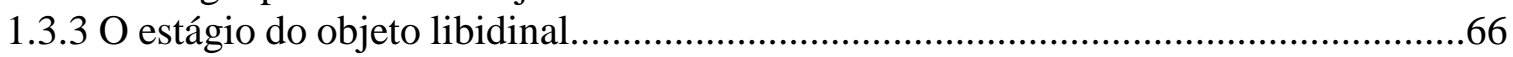

$1.4 \mathrm{O}$ desenvolvimento do bebê no primeiro ano de vida na perspectiva de Winnicott.......78

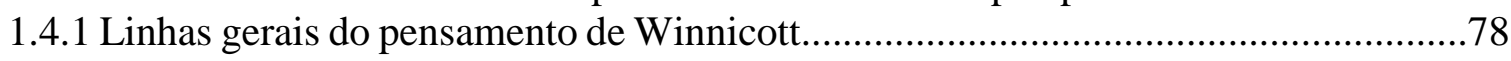

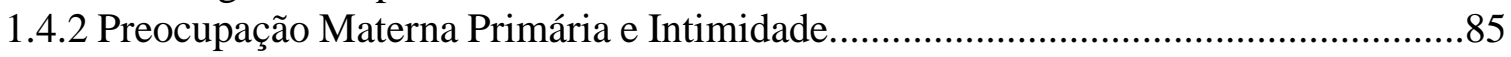

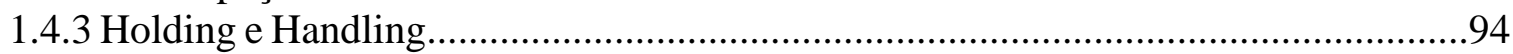

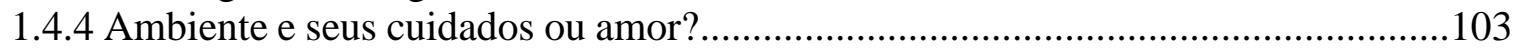

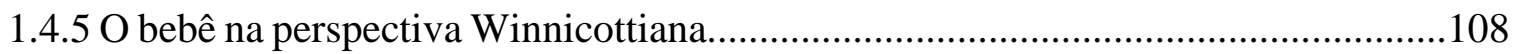

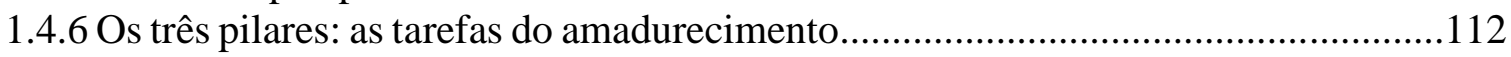

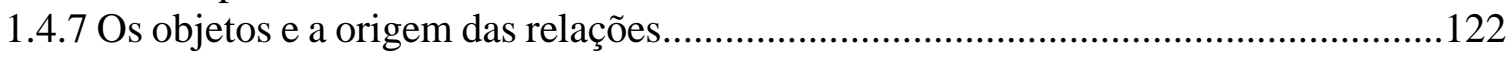

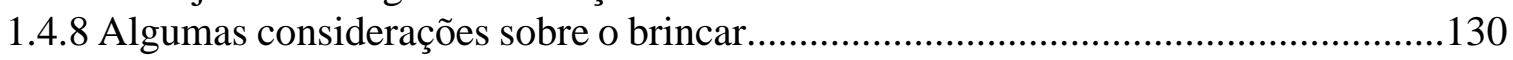

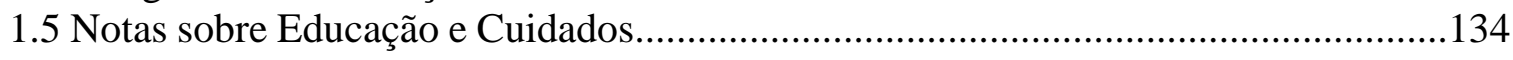

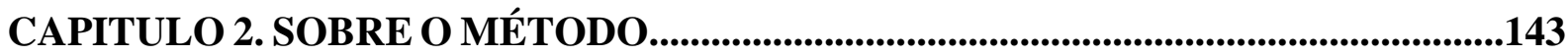

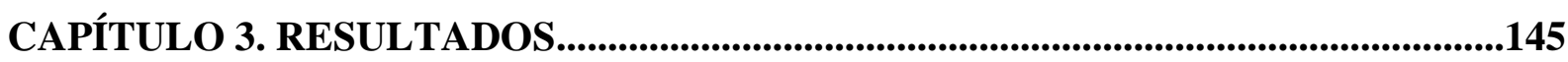

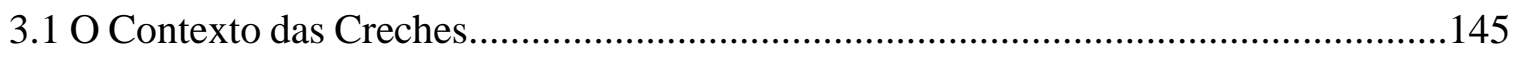

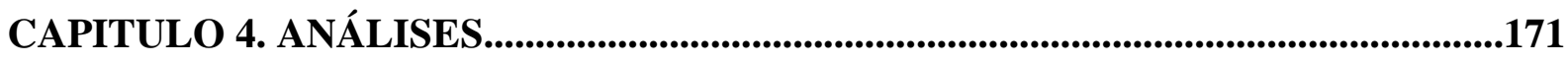

4.1 Os cenários de cuidados com os bebês nas creches...................................................171

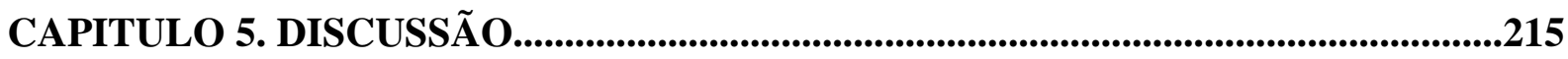

5.1 Entre Ações e "Conversações": delineando as relações de cuidados com os bebês nas

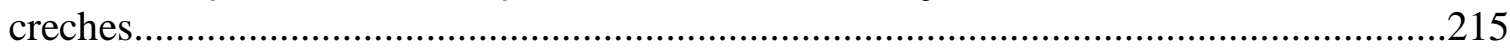

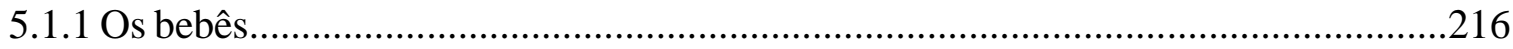

5.1.2 As Educadoras e Professoras: as relações de cuidados com os bebês.......................221

5.1.3 Entre Observação, imprevistos e conversas: a pesquisadora..................................226

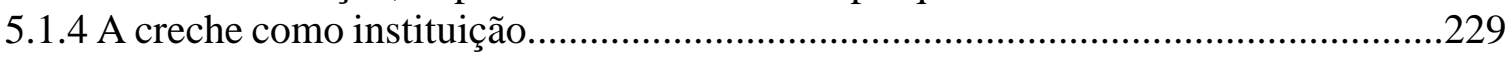

5.1.5 Das aberturas possíveis: os efeitos do acompanhamento nas creches......................230

CAPITULO 6. CONSIDERAÇÕES FINAIS.................................................................240

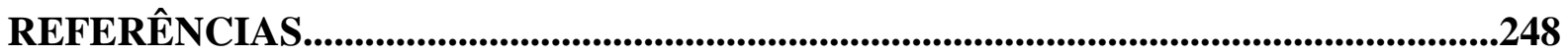




\section{Apresentação}

Profissionalmente, oportunidades de trabalhar com crianças, tanto em instituições concretas como no exercício clínico de consultório foram ampliando meu interesse em estudar o desenvolvimento das crianças, assim como foram surgindo dúvidas e questionamentos sobre o tema.

Observo que, em meu percurso como psicóloga, não tive (e, acredito, ainda não tenho) preferências por clientela de trabalho. No entanto, noto que, apesar disso, os pequenos parecem escolher a parceria e o trabalho acontece. É divertido quando, em uma entrevista, as crianças "saltam" na frente dos pais para participar e mostrarem-se por si próprios e, mesmo quando eles não usam palavras, algo parece acontecer... É o caso dos bebês!

Em um dado momento, comecei a me encontrar com crianças cada vez mais novas e, em suas histórias, observei que elas iniciavam, muito cedo, uma vida educacional, pois as creches ou as escolas de recreação infantil acolhiam essas crianças diariamente e por longos períodos de tempo, como uma alternativa aos cuidados da família. Assim, comecei a pensar sobre os bebês em creches...

Segundo Santos e Moura (2002), ao menos 8\% das crianças brasileiras de zero a três anos estavam matriculadas na pré-escola em 1999. Os autores mostram, ainda, que, em 1998, o país tinha 10.519 creches regulares e cadastradas que atendiam cerca de 448 mil crianças menores de quatro anos.

As importantes mudanças nos cenários contemporâneos social, cultural e econômico têm levado a uma transformação das relações familiares. Nesse contexto, observa-se que as famílias passaram a contar muito mais com o apoio extrafamiliar, principalmente das instituições educacionais como espaço para a permanência dos filhos, tendo em vista que a rede familiar de apoio tem se tornado cada vez mais rara.

Rapoport e Piccinini (2004) apontam que a migração das pessoas para as grandes cidades tem ocasionado o distanciamento entre as famílias e vizinhos, diminuindo o apoio destas redes, bem como a própria diminuição do tamanho das famílias. Soma-se a isto as mudanças de comportamento social que tem revelado um distanciamento das relações sociais e um aprofundamento em um processo de maior individualidade dentro da própria família. 
As autoras ainda comentam que empregadas, babás e creches têm se revelado como alternativas para os cuidados das crianças. Sugerem que, mesmo em famílias nas quais as mães não trabalham, as instituições de educação infantil mostram-se um espaço para o contato e socialização das crianças.

Além disso, indicam que o perfil das famílias que procuram a creche como uma alternativa tem se modificado ao longo dos anos. O que inicialmente se mostrava como um recurso somente para as famílias operárias e de classe média, cujas mães também precisavam trabalhar, hoje, também se aplica as famílias de alto poder aquisitivo.

A decisão de buscar a creche como um lugar de cuidados para bebês e crianças parece existir, cada vez mais, como uma escolha das famílias. Esse tipo de cuidado inspira interesse à medida que parte do desenvolvimento físico e psíquico da criança fica, atualmente, dividido entre o ambiente familiar e o ambiente educacional.

Em São Paulo, outra questão que sinaliza mudança na maneira como se entende a função das creches está na transferência da secretaria responsável por sua organização e gestão, deixando de ser a Secretaria Municipal de Assistência Social e indo para a Secretaria Municipal de Educação. Tais mudanças trazem o cumprimento da legislação que prega a importância da qualificação e formação do educador de creche, exigindo a formação em nível superior.

A esse respeito, Bogus et al.(2007) observam que, a partir de 1996, a Lei de Diretrizes e Bases da Educação Nacional determina que as creches e pré-escolas têm como objetivo atender o desenvolvimento intelectual, social e emocional da criança. Nesse contexto, conforme aponta Mariotto (2003), a creche passa a ter cada vez mais um estatuto educacional e não apenas assistencial, como se caracterizava em seu surgimento.

Para Mariotto (2003), todas essas reformulações para a adequação ao novo modelo transcendem a questão metodológica e curricular, requerendo uma tentativa de integrar as funções de cuidar e educar o que, por sua vez, exige dos profissionais da educação e daqueles que atuam na área, uma reflexão sobre sua função e o lugar que ocupam na instituição educacional.

Aqui, abre-se um campo importante de trabalho para a psicologia, pois diante desse processo de mudança, as creches estão operando em um novo modelo e, talvez, essas transformações possam influenciar o desenvolvimento dos bebês. Tal reflexão é relevante à medida que a creche parece tomar distância de ser o lugar do cuidar para assumir o lugar do educar o bebê. 
Com essas questões, tive a oportunidade de ingressar, no primeiro semestre de 2012 no grupo de pesquisa coordenado pela Prof. ${ }^{a}$ Dr. ${ }^{a}$ Maria Cristina Kupfer no projeto intitulado: "Metodologia IRDI - uma intervenção com educadoras de creche a partir da psicanálise”, com financiamento da FAPESP. Nesse grupo, colaborei com a aplicação da metodologia IRDI nas creches, acompanhando um grupo de 24 bebês de zero a dezoito meses, bem como o grupo de educadoras responsáveis por estes bebês em duas creches da cidade de São Paulo.

Para melhor compreensão da pesquisa citada é interessante destacar que os Indicadores Clínicos de Risco para o Desenvolvimento Infantil (IRDI) nasceram de uma Pesquisa Multicêntrica solicitada pelo Ministério da Saúde.

Era pretendida pelo Ministério da Saúde a elaboração de um manual de crescimento e desenvolvimento a ser utilizado por pediatras da rede de saúde pública. Para este manual havia a sugestão de inclusão de indicadores psíquicos de desenvolvimento infantil.

Com o objetivo de construir os indicadores clínicos de desenvolvimento foi desenvolvida a Pesquisa Multicêntrica. Para tanto, foi organizado um grupo com 10 especialistas em psicanálise com conhecimento sobre desenvolvimento infantil de zero a 18 meses em termos pediátricos.

Este grupo elaborou um protocolo com 31 indicadores que foram estudados e validados num estudo longitudinal entre os anos de 2001 e 2008. Sendo que, a partir de 2004 esse protocolo passou a integrar um projeto temático FAPESP que se concentrava nos indicadores clínicos de risco, na tentativa de identificar sinais precoces de transtornos graves de desenvolvimento.

Destaca-se que "o pressuposto que norteia os indicadores é o de que as bases da saúde mental se estabelecem nos primeiros anos de vida e são dependentes das relações corporais, afetivas e simbólicas que se estabelecem entre o bebê e sua mãe (ou substituto)" (KUPFER et al., 2012, p. 135).

Isso nos leva a dizer que o protocolo IRDI foi introduzido para uso entre os pediatras durante as consultas de rotina dos bebês. Nessas ocasiões, acompanhavam as relações entre as mães e seus bebês e utilizavam os indicadores como leitura para o desenvolvimento psíquicos dos bebês.

Assim, a Metodologia IRDI teve origem no instrumento IRDI (31 indicadores) e sua utilização passou a ocorrer como um instrumento de intervenção, mais do que avaliação. Isto porque, durante a pesquisa, "para alguns pediatras, os indicadores serviam para nomear 
aspectos do desenvolvimento psíquico que eles podiam pressentir, mas sobre os quais não podiam intervir" (KUPFER et al., 2012, p.135).

Dessa forma, os IRDIs foram se alinhando como "orientadores do olhar dos médicos" (idem) e em decorrência, modificações ou inflexões na relação das mães com os bebês foram propostas a partir dos indicadores. Este foi o caminho que indicou que os IRDIs poderiam ser aliados no sentido de promover saúde mental, não se restringindo a proposta inicial de avaliação e acompanhamento do desenvolvimento psíquico.

Assim, outro argumento a favor do IRDI seria compreendê-lo como um modo de olhar, um auxiliar na leitura de alguns fenômenos indicativos de desenvolvimento psíquico observáveis na relação entre um bebê e um adulto, seja a mãe ou um substituto que se encarregue dos cuidados com a criança.

Nesse sentido, como propõem Kupfer, Rocha, Cavalcanti, Escobar e Fingermann (2008), entender a prevenção como cuidado significaria dizer que, prevenir é identificar sinais ou indicadores de sofrimento e, não sinais de uma doença. Isso significa dizer que os IRDIs são indicadores de desenvolvimento, portanto, podemos olhar na direção da saúde, buscando facilitar que os bebês se desenvolvam ou encontrem condições para tal.

É com vista a promoção do desenvolvimento dos bebês e não apenas detecção de sinais precoces de entraves para desenvolvimento psíquico que surge a pesquisa de acompanhamento em serviço nas creches, conforme citado acima.

A participação na pesquisa favoreceu o contato com o contexto das creches. Assim, dois anos de trabalhos semanais com os bebês e as profissionais permitiram o conhecimento de muitas situações das práticas de cuidados das creches com os bebês. Muitos encontros e desencontros entre profissionais e bebês foram acompanhados enquanto a primeira pesquisa era levada a cabo.

Esse trabalho tornou mais forte nosso interesse pelo desenvolvimento daqueles bebês. Assim, é no interior dessa pesquisa, ou seja, a partir da colaboração no acompanhamento em serviço que nasce o presente estudo. A questão era como estudar, uma vez que não queríamos estudar apenas o desenvolvimento dos bebês, mas os bebês e suas professoras. Então, pensouse em estudar as relações entre as profissionais e os bebês, mas ainda assim, estudar o desenvolvimento era muito amplo. 
A experiência nos mostrou o caminho. Era importante olhar para os cuidados que se apresentavam na relação dos profissionais com os bebês. Partindo dos cuidados, talvez, pudéssemos pensar sobre o desenvolvimento dos bebês nesse contexto.

Acompanhando os estudos mais atuais realizados na área de educação infantil, especialmente com bebês, vimos que estes estudos privilegiaram a relação professor-bebê como uma posição da qual observar sinais precoces de risco para o desenvolvimento ou risco psíquico (Metodologia IRDI). Esses estudos, realizaram pelo acompanhamento em serviço, a leitura das relações e propuseram intervenções que auxiliassem as mesmas (MARIOTTO, 2009; KUPFER; BERNARDINO; MARIOTTO, 2012, KUPFER; BERNARDINO; MARIOTTO, 2014).

Dessa forma, realizou-se um breve levantamento dos estudos que tratavam da questão dos cuidados dos bebês em creche. Vamos à eles e, depois, retomaremos o que pensamos com eles e a partir deles.

Veríssimo e Fonseca (2003) investigaram as representações de educadoras de creche sobre o cuidado com a criança. Nesse estudo, mostram como a creche compreende e executa esses cuidados. Destacam que, entre as coordenadoras, verificaram que o papel da creche é educar e cuidar. Definindo a instituição creche como um lugar de educação, entendendo-a como "um processo que engloba a transmissão de conhecimentos, cultura, valores e regras sociais" (VERÍSSIMO; FONSECA, 2003, p. 26).

Nesse sentido, o processo educativo não contemplaria apenas atividades pedagógicas, como também o cuidado, definido como ação promotora do bem-estar e das interações na creche.

A visão das educadoras das creches estudadas a respeito dos cuidados não apenas segue a mesma direção apontada pelas coordenadoras, como também reforça que a função pedagógica não pode ser exercida sem a oferta de cuidados, pois são eles que contribuem e sustentam o papel educacional da creche.

Outro aspecto destacado pelas profissionais entrevistadas foi de que a creche facilita a socialização e as situações de interações sociais, contando com a diversidade de adultos e crianças em convivência diária, somando-se a diversidade de atividades oferecidas pela creche.

O ponto central destacado pelos dois grupos de profissionais (coordenadoras e educadoras) ressalta a creche como um espaço que "supre necessidades da criança, 
proporcionando-lhe bem estar" (VERÍSSIMO; FONSECA, 2003, p. 28). O que, segundo as autoras, se alinha às ideias mais atuais sobre a creche como um direito da criança, assim sendo, visaria atender às necessidades específicas de desenvolvimento. Entretanto, as autoras não esclarecem quais são essas necessidades específicas às quais se referem no estudo, que tipo de cuidados são eles, como eles podem ser desenvolvidos e como contribuiriam no atendimento a essas necessidades.

O texto segue apontando quais são as principais ações que a creche pratica e identifica como cuidado às crianças. A primeira ação destacada se refere ao processo de adaptação das crianças à creche. Nesse processo,

[...] há preocupação com sua tranquilidade emocional; as educadoras referem-se continuamente às necessidades das crianças, seus desejos e angústias, investindo seus conhecimentos e habilidades para detectar e atender as necessidades afetivas, as angústias da separação durante a adaptação e a chegada, tentando lidar com a confusão que muitas vezes se estabelece nesses momentos (VERÍSSIMO; FONSECA, 2003, p. 32-33).

Aqui, há uma referência aos cuidados em termos psicológicos, voltados as situações desencadeadas, principalmente, por momentos de afastamento da criança da família.

Outra ação relatada diz respeito ao acompanhamento da progressiva autonomia das crianças com a idade, cujas ações se voltariam como auxílio "a criança no aprendizado sobre compartilhar, manter ou melhorar sua auto-estima, e desenvolver autonomia e responsabilidade" (VERÍSSIMO; FONSECA, 2003, p. 29).

Uma terceira ação seria procurar garantir atenção individualizada em um espaço caracterizado pelo aspecto coletivo e a quarta, e última, seria o estabelecimento de um relacionamento educador-criança livre de autoritarismo e imposições.

O texto também apresenta o levantamento de algumas situações controversas nas creches estudadas. O primeiro apontamento feito revela que, ao mesmo tempo em que as creches afirmam que educar é uma função que está nas bases de sua missão, o cuidar é não apenas parte do papel da creche, como promoveria o bem-estar necessário para o desenvolvimento da aprendizagem das crianças, compreendem também que cuidar é sinônimo de assistencialismo, distanciando o cuidado de um atributo profissional. Como se o cuidar 
trouxesse o demérito ao trabalho educativo, portanto, "cujo valor é inferior em termos de papel profissional” (VERÍSSIMO; FONSECA, 2003, p. 32).

Cruz (1996) discute a formação do educador infantil e ressalta que entre as concepções preconizadas pelo Ministério da Educação e dos Desportos está “a integração entre as diversas necessidades da criança que devem ser contempladas, sendo o cuidado e a educação vistos como funções complementares e indissociáveis, além de complementares aos cuidados e educação efetuados pela família" (CRUZ, 1996, p.80-81).

Cerisara (1999) esclarece que essas concepções decorrem da própria história das creches no Brasil, que em suas origens funcionaram, inicialmente, como instituição assistencialista e, posteriormente, criaram-se modelos que foram denominados educativos. A autora ressalta que embora se refira aos dados históricos, essas concepções resistem em nosso tempo, portanto, são atuais em muitas práticas.

Ao continuar sua discussão, Cruz (1996) aponta que a ideia de educação da criança pequena não se desvia da necessidade de incluir os fazeres no campo da proteção e apoio do dia-a-dia das crianças, desta forma, mostra que as ações como alimentar, lavar, trocar, curar, proteger e consolar são compreendidas como cuidar e integram o campo do educar.

\footnotetext{
Nesse sentido, tem profundas repercussões a afirmação de que os cuidados com a saúde, a proteção contra os perigos físicos, as relações afetivas estáveis, a compreensão e o apoio na aquisição de diversos tipos de habilidades estão entre as muitas necessidades de todas as crianças [...] (CAMPOS,1994b apud CRUZ, 1996, p.81).
}

Essa compreensão de que cuidar circunscreve mais os cuidados de natureza física, vistos como cuidados com a saúde e higiene, favorece que não sejam vistos como cuidados educativos e, consequentemente, são vistos como atividades que oferecem menor prestígio profissional. Nessa linha, aparecem dois critérios para esse desencanto: a idade da criança e a proximidade com os cuidados corporais. Visto da ótica da hierarquia profissional, isso quer dizer "quanto menor a criança, menor o prestígio e quanto maiores os cuidados, também menor é o prestígio da profissional" (CRUZ, 1996, p. 81).

Outro ponto levantado sobre esse aspecto se refere ao fato de que as crianças pequenas, por requererem maiores cuidados, não aproveitariam e nem precisariam muito de atividades em 
relação ao desenvolvimento cognitivo, afetivo e social. O que implicaria em menor exigência da formação de profissionais da educação, enfatizando mais a pessoa do profissional e seu jeito do que sua formação e qualificação.

Desse modo, a autora destaca um tipo de separação que se opera no campo da educação infantil entre educar e cuidar. Enfatizando que é preciso mudar a "concepção tanto da criança e de seu desenvolvimento quanto da própria ideia de educação infantil” (CRUZ, 1996, p. 81).

Em suas considerações, a autora menciona a crença existente de que as pessoas que trabalham com crianças precisariam ter amor ao trabalho e que nele pudessem se sentir à vontade, expressando esse amor de forma a criarem um ambiente estimulante como maneira de constituir um serviço de qualidade. Apesar de partilhar dessa crença, Cruz (1996) insiste na questão da formação dos profissionais e questiona as condições para a realização desse trabalho de qualidade.

\footnotetext{
Como o educador pode ter amor ao seu trabalho e nele se sentir à vontade, se recebe um salário tão baixo, não tem perspectivas profissionais, não conta com uma clara proposta pedagógica e um bom currículo, e não recebe acompanhamento competente e regular do seu trabalho? Como pode demonstrar carinho e dar a devida atenção às crianças tendo um tão grande número delas sob sua responsabilidade e jornadas de tão trabalho extenuantes? Como pode criar um ambiente estimulante sem o mínimo de recursos materiais para isso? (CRUZ, 1996, p.88).
}

Cerisara (1999) menciona que a Lei de Diretrizes e Bases (LDB) de 1996 inseriu a educação infantil como a primeira etapa da educação básica e, ao fazê-lo, a educação infantil se constituiu como um nível de ensino. Isso, com o argumento de que essa inserção traria avanços na construção de um trabalho com características educativo-pedagógicas que atendessem as especificidades das crianças de 0 a 6 anos. Além disso, favoreceria a formação dos profissionais para o trabalho, tanto técnica quanto em serviço e traria a valorização em termos de técnico-administrativos e econômicos.

No entanto, a autora aponta os riscos dessa inserção de creches e pré-escolas como um nível de ensino, uma vez que se sabe que essas instituições não podem "ser depósitos de crianças, substitutas maternos ou hospitais, mas também, elas "não devem reproduzir as práticas sociais que têm sido desenvolvidas nas escolas de ensino fundamental" (CERISARA, 1999, p.15). 
Assim, enfatiza que o desafio é buscar a especificidade do trabalho pedagógico a ser desenvolvidos nas instituições de educação infantil. Para tanto, é necessário ter clareza que esse trabalho não pode se pautar em ensinar conteúdo ou disciplinas, ou mesmo se guiar pela fragmentação desses conteúdos escolares. Uma das saídas apontadas seria envolver "todos os processos constitucionais da criança (intelectuais, sociais, emocionais, expressivos, culturais e interacionais).

Outro desafio destacado se refere ao caráter de complementariedade que as instituições de educação infantil apresentam em relação à família, que se volta ao "desenvolvimento de atividades ligadas ao cuidado e à educação dessas crianças” (CERISARA, 1999, p.16).

Entretanto, a autora acrescenta que a defesa do caráter pedagógico dessas instituições, ocorreu no sentido de valorizar as atividades ligadas ao ensino, à transmissão de algo, o que reproduz ou antecipa as práticas do ensino fundamental. Esse reducionismo pedagógico contribui para a desvalorização das atividades relacionadas aos cuidados com as crianças pequenas. E não favorece a compreensão de que as crianças dependem de cuidados dos adultos para sua sobrevivência, além do fato de permanecerem diariamente, por longo períodos de tempo, nessas instituições de educação infantil.

O artigo "Considerações sobre qualidade na educação infantil", ao discorrer sobre educação e cuidado também na visão dos direitos da criança, argumenta que não basta discutir apenas a necessidade de ampliação da oferta de vagas, pensando-se em uma proporção adulto e criança mais adequada. Essa ação se prestaria, talvez, a garantir minimamente alguns direitos da criança, como: o acesso à educação, "o direito a uma atenção mais individualizada, a um ambiente mais seguro e quiçá mais aconchegante e estimulante, à higiene e saúde, por exemplo" (CORRÊA, 2003, p.102-103).

A discussão que traz sobre a questão do cuidar vai na mesma direção dos argumentos apresentados. No entanto, acrescenta que além do cuidado ser algo muito presente no cotidiano da educação infantil, ele também passa a ser negado.

[...] porque tido como antiprofissional, ora visto como algo característico ou mesmo inerente à condição feminina, materna; assim, em ambos os casos, o cuidado é compreendido não como uma caraterística ou atributo profissional típico daqueles que trabalham com crianças, mas, antes, como característica doméstica, situada no âmbito da vida privada e, sobretudo, associada à condição feminina" (CORRÊA, 2003, p. 106). 
A dimensão da desvalorização do cuidado e a condição de indignidade do cuidado, voltam à pauta, agora na perspectiva de ser um trabalho restrito às mulheres, à condição feminina.

A autora também sinaliza que há poucas iniciativas, "além da denúncia sobre a 'falta de qualificação' ou de 'competência técnica' para que as professoras reflitam acerca de suas práticas, problematizando-as e buscando meios coletivos para que seu trabalho possa sofrer as transformações necessárias e desejadas" (CORRÊA, 2003, p.110).

Conclui que, para além dessas iniciativas, a propositura de inclusão nos currículos de formação inicial ou em formação em serviço, de conteúdo sobre a dimensão do cuidado da criança pequena em seus direitos é fundamental.

Vitta e Emmel (2004), em sua pesquisa, verificaram mediante entrevistas as concepções relativas ao cuidar e educar junto às profissionais de berçários. E observaram que os documentos oficiais que tratam da educação infantil apresentam pouca discussão sobre a faixa etária dos 0 aos 18 meses. Sendo ainda, pouco esclarecedores sobre a relação entre as atividades de cuidado e educacionais.

Verificaram que as profissionais "classificam as crianças como pertencentes às famílias com problemas (financeiro, matrimonial etc.) que impossibilitam cuidar e educar (educar entendido como disciplinar) a criança de modo satisfatório" (VITTA; EMMEL, 2004, p.181). As autoras apontam que as atribuições do trabalho em berçário se mostraram atreladas à função das profissionais, como entendiam ser capacitadas para oferecer os cuidados essenciais, compreendiam que o berçário tinha a função de prover esses mesmos cuidados.

\footnotetext{
No entanto, em muitos discursos, as atividades de cuidados são realizadas dentro de uma rotina que envolve espaço e tempo limitados e os atos são automáticos, obedecendo a uma ordem que auxilie na organização dessa rotina. Para muitas, nesse automatismo perde-se a oportunidade de interação com a criança e, consequentemente essa proximidade entre cuidado e educação não se efetiva na prática (VITTA; EMMEL, 2004, p.183).
}

Ainda, constataram que o conceito de educar se relacionava com a formação moral da criança, quer dizer, tratava-se de ensinar o certo e o errado, a conviver com outras pessoas, a ter bom comportamento e a aprender o autocuidado. Mas, na prática, os pesquisadores 
perceberam que as profissionais exerciam a educação como disciplinarização das crianças no que concernia aos hábitos de higiene, alimentação e convivência social.

Os pesquisadores tenderam a ver essas manifestações espontâneas e baseadas na experiência pessoal como fatores que não contribuíam para os cuidados das crianças e concluíram que, "embora as profissionais consigam relatar aspectos que supõem a existência de relações entre o cuidado e a educação, enquanto desenvolvimento global da criança, estes se apresentam de forma descontextualizada e não como uma atividade planejada e rotineira das profissionais" (VITTA; EMMEL, 2004, p.187).

Finalizam entendendo que isso se justificava pela falta de formação das profissionais e que programas que valorizassem a prática cotidiana das creches e reconhecem, a partir delas, as especificidades da educação em berçários se faziam necessários.

O estudo de Becker, Bernardi e Martins (2013) investigou, pela análise de entrevistas, as práticas de cuidado de educadoras de berçário e suas crenças a respeito das necessidades dos bebês. Verificaram que as práticas e crenças de cuidados mais valorizadas entre as educadoras quando questionadas sobre as necessidades dos bebês se referiam aos aspectos da relação, destacando, nas falas, expressões como amor, afeto, carinho, atenção e cuidado.

Quando questionadas sobre as ações que consideravam importantes com os bebês, as respostas mais valorizadas foram colo e contato físico. Essas análises indicaram que a maior valorização se referia aos aspectos de sustentação dos bebês (holding). Um número menor de educadoras identificou o manuseio dos bebês como uma necessidade dos bebês, comentaram, por outro lado, essas práticas de manuseio dos bebês como algo importante no cotidiano, se referiam especialmente a importância do toque e do contato físico, como massagens, pequenas brincadeiras durante as trocas. Quanto as práticas realizadas por elas, a estimulação motora foi a que mais apareceu. Comentários sobre uso de materiais para estimular o desenvolvimento do tônus muscular, como estimular engatinhar, sentar, deslocar-se, ficar de pé etc., receberam destaque.

Como forma de apresentar os objetos aos bebês, a maioria das educadoras apresentou, entre as práticas realizadas, o uso da linguagem com forma de apresentar o mundo aos bebês, ressaltando a importância de conversar com eles, explicar (mostrar) o que está acontecendo no ambiente, explicar o que está acontecendo em dado momento com o próprio bebê ou outros. 
A utilização da linguagem como forma de apresentação do mundo ao bebê também foi mencionada quando as educadoras descreviam práticas que costumavam realizar: músicas, histórias, acho que também é importante...Música, história...é que tem tanta coisa que a gente faz com eles. Quando tu alimenta, notar se está bom. Quando eu alimento eu não misturo o alimento, pra pegar o feijão, o arroz e a carne. Eu vou falando: 'vamos perguntar qual o gosto do feijão, vamos perguntar qual o gosto do arroz, da batata' (BECKER, BERNARDI; MARTINS, 2013, p.557).

Também verificaram que as educadoras utilizavam o ambiente como forma de estimular os bebês, falando da disposição dos móveis na sala, as cores, os tipos de objetos, os brinquedos e alternância entre eles etc. Entre as falas das educadoras, poucas enfatizaram o uso da estimulação geral como atividade pedagógica, parecia que não eram orientadas por práticas pedagógicas específicas.

Aspecto importante destacado pelas autoras, também já enfatizado nos estudos anteriores, diz respeito a necessidade de diferenciar educar e cuidar. Observaram que as educadoras apresentaram necessidade de se afirmarem como profissionais da área de educação, para se discriminarem de outros cuidadores. "Neste sentido, parece que a aprendizagem valorizada no contexto da Educação Infantil está ainda descolada de práticas focadas nas necessidades básicas do bebê” (BECKER et al., 2013, p.558).

Encerram seu estudo enfatizando a importância da existência de formação específica para os profissionais que trabalham com bebês.

Pudemos observar que esses estudos enfatizam a dualidade entre educar e cuidar presente no contexto da educação infantil, especialmente em creches e pré-escolas. Os estudos ainda indicam a necessidade de buscar maior integração entre esses aspectos do trabalho com crianças pequenas.

Os estudos foram unânimes em indicar que as alternativas ou as "soluções" para a resolução dessa dicotomia entre educar e cuidar e, mesmo, as melhoras em relação à dimensão do cuidado estaria na inserção desse aspecto no currículo de formação tanto formal quanto em serviço. Enfatizando que a falta de formação técnica, a instrução ou ampliação dos conhecimentos sobre os cuidados de bebê e crianças pequenas seria o "problema" a ser tratado.

Em todos, destaca-se a importância de pensar a dimensão dos cuidados na creche. Alguns procuraram investigar como aconteciam esses cuidados, no entanto, não observou-se 
nesses estudos nenhuma experiência que procurasse operar sobre os cuidados como objeto de estudo, mais precisamente, nenhum deles se propôs a agir sobre esses cuidados na creche.

Refletindo sobre esses pontos e considerando nossa experiência de acompanhamento em serviço das profissionais em cuidado com os bebês, bem como, o caráter interventivo desse acompanhamento, nos propusemos a configurar as relações de cuidados como nosso objeto de estudo.

Assim, nosso objetivo é analisar as relações de cuidados que se estabelecem entre as profissionais e os bebês em creches para discutir como esse ambiente contribui para o desenvolvimento psíquico dessas crianças.

Para isso, nosso primeiro capítulo traz como fundamentos um breve histórico do surgimento das creches no Brasil e as mudanças dessa instituição até nossos dias. Na sequência, apresentamos três referenciais psicanalíticos para pensar o desenvolvimento dos bebês.

Começamos por Freud e algumas considerações sobre o narcisismo, seguimos com Spitz que apoiado nos pressupostos freudianos desenvolve uma teoria do desenvolvimento dos bebês em seu primeiro ano de vida, enfatizando, principalmente, o desenvolvimento de bebês em instituições. Finalizamos os fundamentos psicanalíticos com o pensamento de Winnicott sobre o desenvolvimento de bebês e a importância do ambiente como facilitador para existência do bebê, denominada de teoria do amadurecimento.

Nosso último capítulo desse bloco, busca fazer uma transição dos cuidados maternos para os cuidados em educação infantil. Destacando, como alguns aspectos desses cuidados podem auxiliar no estabelecimento de algumas relações entre educação e cuidados, buscando mostrar como esses conceitos estão interligados, apresentando-se de igual importância na educação infantil e na contribuição ao desenvolvimento dos bebês em creches.

O segundo capítulo apresenta o método realizado em nosso estudo, mostrando a partir do acompanhamento de profissionais em serviço, como levantamos nossos dados partindo de observações e algumas intervenções no contexto das relações de cuidados das profissionais com os bebês nas creches.

No terceiro capítulo, descrevemos essa experiência de campo, apresentando as observações e ações da pesquisadora em cada uma das creches, traçando os perfis de cada instituição e suas singularidades, bem como apresentando as relações entre profissionais e bebês, entre as profissionais, equipe das creches e pesquisadora, trata das mudanças observadas 
nos cenários, tanto aquelas que se relacionavam com as instituições quanto as que se deram como efeito do acompanhamento.

As análises, nosso quarto capítulo, traz fragmentos e histórias em formato de cenas, descrevendo as relações de cuidados dos bebês nas creches e, apresenta a cada cena comentários analíticos das relações das profissionais com os bebês, a instalação dos cuidados nestas relações, as alterações nas creches e no desenvolvimento psíquico dos bebês.

Nosso quinto capítulo, discutimos a partir das análises realizadas, como apareceram os bebês nas creches, como eram as relações de cuidados com os bebês, como apareciam as profissionais e a própria creche. Também discutimos, como a partir da inserção da pesquisadora e a propositura de algumas intervenções, os cenários de relações nas creches foram se alterando e criando relações de cuidados com as crianças, bem como com as profissionais.

Por fim, nosso sexto e último capítulo, traçamos nossas considerações, estabelecendo algumas relações com nossos objetivos e pressupostos, destacando como se estabeleciam as relações de cuidados nas creches, bem como os aspectos que favoreciam ou não o desenvolvimento das relações e dos cuidados com os bebês. Apontamos também para outros resultados que, apesar de não comporem nosso objetivo inicial, despontaram em nosso estudo e surpreenderam. 


\section{FUNDAMENTOS}

\subsection{A história das creches no Brasil}

O surgimento das creches no Brasil constitui-se de aspectos políticos, sociais e econômicos que, ao longo do tempo, configuraram diferentes instituições destinadas aos cuidados da infância até que chegasse ao que hoje conhecemos por creches.

Observa-se que o surgimento das creches também está entrelaçado com o próprio surgimento do conceito de infância e vincula-se inclusive à questão da infância em abandono no Brasil.

As instituições de cuidado com a infância nascem influenciadas por movimentos históricos de caráter distintos: o filantrópico, o higienista, o assistencial social e o educacional (GEIS, 1994).

As primeiras instituições destinadas aos cuidados de crianças no Brasil foram denominadas instituições asilares. Estes asilos infantis nascem no Brasil ainda no século XVIII, na sociedade colonial brasileira, uma sociedade ainda regulada pelo regime escravocrata, em que as primeiras crianças a serem acolhidas por estes asilos seriam os filhos de escravas.

Durante o período colonial brasileiro, o tripé econômico-social poderia ser descrito como assentado no trabalho com agricultura, com mão de obra escrava e regido pelo sistema patriarcal, modelo familiar desse período social. De acordo com esse modelo, as relações familiares estavam alicerçadas no homem, no pai, no chefe, posto no lugar de autoridade. Subentendida, aqui, está a condição de submissão da mulher ao homem e o lugar da criança divido em dois: "a criança da casa-grande e a criança escrava" (FARIAS, 2013, p.48).

Mabel Farias (2013) destaca, ainda, que mesmo a criança da casa-grande estava longe de ser o reizinho, faltando a ela o "amparo, a sensibilidade e a intimidade nos relacionamentos" (p.50). Com relação à criança escrava, estas eram presenteadas aos filhos dos senhores de escravos para servir-lhes de companhia, um escravo em miniatura ou brinquedo. 
Nessa época, os filhos dos proprietários de escravos eram amamentados e cuidados por escravas, dispensando as senhoras (mães) das ocupações com a maternagem de seus filhos.

Verifica-se que "o aspecto materno da condição feminina durante esse período não possuía uma valorização social especial, já que seu objeto, a criança pequena, também não a tinha" (PARDAL, 2013, p. 67).

Diante desse quadro, aos filhos das escravas eram dados os mais diferentes destinos, incluindo o abandono, para que estas pudessem servir como ama de leite para os filhos dos senhores e que os cuidados com os próprios filhos não viessem a atrapalhar tal tarefa (MERISSE, 1997; FARIAS, 2013)

A promiscuidade masculina e a prostituição no sistema escravocrata acentuavam ainda mais a situação de abandono de crianças. As mulheres dos senhores eram mantidas isoladas e com saídas consentidas apenas para irem à igreja. Aos homens era concedida toda a liberdade, além de muitas facilidades em submeter mulheres pobres como prostitutas, além de alugar ou explorar sexualmente mulheres escravas. De acordo com Farias (2013) "a situação da classe branca desfavorecida não diferia muito da miséria do negro, a não ser pela liberdade" (p.52).

A autora destaca que as mulheres brancas pobres tinham como marca de suas maternidades a subnutrição e lutavam para garantir a vida de seus filhos de acordo com suas condições, mas muitas se curvavam às dificuldades, doavam ou abandonavam os filhos.

Merisse (1997) acrescenta que diante desses fatos, o abandono de crianças se torna comum, vendo-se o abandono de crianças pelas ruas em condições totalmente indignas e muitas vezes destinadas à morte. A este respeito, MARCÍLIO (2006) acrescenta que nos registros das atas de Mesa da Santa Casa de Salvador encontram-se relatos de que os bebês eram abandonados em vários lugares da cidade, durante a noite e, muitas vezes, amanheciam mortos, sendo alguns deles atacados por animais.

Como se pode ver, a escravidão e a prostituição não parecem figurar como as únicas causas do abandono de crianças. O sistema colonial vigente na época, com seu regime escravocrata e de acumulação de riqueza foi responsável pela determinação de uma grande situação de pobreza entre a população. E com o fim da escravidão, o que permaneceu foi a concentração de riqueza nas mãos de poucos com o predomínio de uma situação social de exclusão e marginalização de boa parte da população.

Entre as causas primeiras do abandono de crianças nas instituições asilares, principalmente as deixadas nas rodas dos expostos, identifica-se a pobreza. Algumas mães 
deixavam seus bebês nas rodas com pequenos bilhetes explicando os motivos para o abandono e, entre estes, os mais comuns eram a pobreza e a falta de leite materno para amamentação dos bebês, em uma época onde alimentação artificial não era usual. Outros fatores comuns ao abandono eram "a morte ou doença do pai ou da mãe, o nascimento de gêmeos, a saída do pai de casa, deixando a mulher ao desamparo, e falta de leite de mãe, dentre outros" (MARCÍLIO, 2006, p. 259).

Outras causas apontadas que vieram a contribuir com o abandono das crianças são: a crescente urbanização, as migrações das zonas rurais para a urbana, e entrada de mulheres pobres como força de trabalho (MARCÍLIO, 2006; FARIAS, 2013).

Tais questões apresentam-se como os principais disparadores para a criação de instituições para o recolhimento da infância em abandono no Brasil. Assim, as primeiras instituições que tiveram origem com esta finalidade no Brasil foram chamadas: Casa da Roda, Casa dos Expostos ou Casa dos Enjeitados (MERISSE, 1997; MARCÍLIO, 1998; 2006).

Entretanto, antes da criação da Casa de Expostos, havia outro sistema de acolhimento de crianças em abandono. Segundo Farias (2013), as crianças abandonadas eram apresentadas à Câmara, nesse sistema as crianças eram entregues a criadores ou amas de leite que recebiam uma mensalidade para cuidar delas. E, em certa periodicidade, essas pessoas deveriam apresentar as crianças à Câmara, mas o que acontecia é que muitas não retornavam e em outros casos as crianças morriam.

Diante do fracasso desse modelo em atender as crianças em abandono, a Câmara, com autorização do Rei, firma convênio e transfere a responsabilidade no atendimento as crianças abandonadas para as Santas Casas de Misericórdia, dessa forma, se mantém apenas subsidiando os custos com tal serviço (MARCÍLIO, 2006).

A Roda de Expostos surge no período colonial e seguirá seu funcionamento até o período republicano, quando tal modalidade de atendimento será extinta. A Casa da Roda destinava-se, particularmente, ao acolhimento de bebês que eram abandonados e era regida exclusivamente pelas Santas Casas de Misericórdia.

A roda funcionava como uma janela que ligava o lado interno ao externo da Santa Casa de Misericórdia. Esse sistema funcionava por uma roda que possuía abertura para que o bebê fosse colocado pelo lado da rua, sem que aquele que deixava o bebê pudesse ser visto ao lado de dentro, garantindo, dessa forma, o anonimato daquele que abandonava a criança. Depois de 
colocado o bebê, girava-se o sistema da roda e o bebê era transferido para o lado interno dos muros, para ser recolhido pela Misericórdia (MARCÍLIO, 2006).

Segundo a autora, as crianças eram acolhidas pela Roda dos Expostos e cuidadas por amas de leite mercenárias, mulheres que recebiam uma ajuda financeira mensal para amamentar os bebês e cuidar deles até que completassem 3 anos, período em que as crianças retornavam à Casa dos Expostos onde permaneciam até os 7 anos de idade. Quando as crianças retornavam ao acolhimento por essas instituições, buscava-se colocá-las em casas de famílias ou encontrar formas de criá-las.

Rizzini e Rizzini (2004) destacam que os cuidados com os bebês eram realizados de forma coletiva, em uma época onde alimentação artificial não era uma prática muito comum e resultava em altas taxas de mortalidade por agravamentos na saúde dessas crianças. Como ainda não dispunham de descobertas e práticas na área da saúde, as Santas Casas de Misericórdia mantinham os cuidados às crianças pelas amas de leite.

Nesse sentido, Farias (2013) esclarece que as crianças entregues a Casa dos Expostos das Santas Casas de Misericórdia eram atendidas no próprio hospital e, observa que:

[...] não havia unidade específica para atender os enjeitados; a criança permanecia em contato com os doentes e não recebia uma alimentação adequada. Inicialmente, a não utilização das amas de leite, por falta de recursos, obrigava o aleitamento artificial, o que agravou profundamente os índices de mortalidade na instituição. Sem condições necessárias de higiene, os instrumentos utilizados eram desde pano linho puído, que, umedecido com leite, era levado à boca de diferentes crianças até a '[...] colher de pau, de prata ou marfim (p.54).

Desta forma, verifica-se que a utilização das amas de leite para os cuidados das crianças abandonadas foi introduzida como estratégia para a redução da mortalidade infantil. Porém, esta forma de cuidado será criticada pelo movimento higienista, que, a rebote, introduzirá “o ideal da mulher-mãe" (p.55), como se verá mais adiante.

Acrescenta-se que estas instituições foram implantadas em diversos estados do Brasil, mas as referências históricas situam as de Salvador, Rio de Janeiro, Recife e São Paulo como as principais. Esses serviços tinham caráter filantrópico, caritativo-religioso e assistencial e o principal objetivo das casas era, pelo acolhimento, reduzir a mortalidade infantil. Como se pode observar, as instituições asilares não se originam como iniciativas do Estado, o papel deste nas políticas públicas de atendimento à infância surge apenas mais tarde como se mostrará. 
Merisse (1997) relata que o referencial de surgimento das primeiras creches no Brasil tem como base este contexto institucional asilar, identificando como clientela inicial atendida pelas creches, a exemplo de São Paulo, crianças órfãs e abandonadas acolhidas em regime de internato.

Nessa época, segundo Kramer (1984), a única regulação jurídica voltada para infância era o Código de Leis e Regulamentos Orphanológicos que cuidava de assuntos referentes a bens e patrimônios, criação de órfãos, sistema de doações, sucessão e tutoria, herança de patrimônio etc., mas nenhuma outra ação voltada para a prevenção ou proteção à infância.

Retornemos a criação das instituições asilares com o objetivo de acolher crianças em abandono e reduzir a mortalidade infantil, acrescido de um crescente interesse médicohigienista que começa a desenvolver-se no Brasil. Os discursos correntes na época diziam que as causas da mortalidade infantil se deviam: 1) "nascimentos ilegítimos, fruto da união entre escravos ou destes com os senhores, 2) a falta de educação física, moral e intelectual das mães", por permitirem o aleitamento através de amas de leite escravas (KRAMER, 1984, p. 52).

Assim, constata-se que as causas descritas culpabilizam a família pela mortalidade infantil. Além disso, acionam a população de origem escrava como fonte de doenças.

Começam a existir ações médicas-higienistas para reduzir a mortalidade infantil dos expostos e também para educar as famílias sobre os cuidados com higiene e alimentação. Tais ações acabam por influenciar o papel social da família, visando principalmente à mulher, para que ela assumisse a amamentação e os cuidados com os filhos, prescindindo das amas de leite (MERISSE, 1997).

Segundo o autor, o movimento higienista vai ganhando cada vez mais força com os avanços da ciência. Aos poucos, pela ação de médicos começa a se integrar às ações do Estado. A partir daí, começa a influenciar não apenas à esfera da saúde, mas também outras áreas do âmbito social. Começa-se a pensar na educação como um veículo para que as práticas higienistas pudessem ser ensinadas e transmitidas à população por meio das crianças, contribuindo para a mudança e a correção dos antigos hábitos higiênicos coloniais.

Nesse caminho, assinala-se que "as instituições pré-escolares foram difundidas internacionalmente a partir da segunda metade do século XIX, como parte de um conjunto de medidas que conformam uma nova concepção assistencial, a assistência científica, abarcando aspectos como alimentação e habitação dos trabalhadores e dos pobres" (KUHLMANN JUNIOR, 1998, p. 81-82). 
O autor destaca que as pré-escolas foram introduzidas com a ideia de novidade, exibidas como propostas modernas e científicas. Assim, a creche destinada a crianças de 0 a 3 anos foi apresentada como alternativa ou, mesmo, oposição às Casas dos Expostos, com vistas ao não abandono das crianças por suas mães.

Reis (2013) discorre que, nessa onda do movimento científico, começam a chegar ao Brasil as ideias de Wilhelm August Fröebel, que defendia mudanças na educação de crianças pequenas, estas mudanças não apenas os conceitos sobre educação e tipos de instituição, mas intervinham na estrutura familiar e nos cuidados com as crianças, abarcando ainda o âmbito público e privado.

Os ideais froebelianos representavam, no período em que surgiram, o rompimento com padrões tradicionais assistencialistas que objetivavam apenas privar a sociedade dos índices de mortalidade infantil, ou, ainda, resguardá-la de uma infância amoral, resultado de famílias despreparadas para assumirem a educação de seus filhos (REIS, 2013, p. 88).

Apesar disso, Reis (2013) observa que esse modelo se comprometia também com o pensamento ideológico dominante, uma vez que, o modelo europeu mantinha a divisão de jardins de infância para crianças pobres e ricas. E, no Brasil, verificaremos que esse modelo educacional de Fröebel serviu apenas para crianças da elite. Pois, tanto o jardim de infância do Rio de Janeiro (1875) quanto o fundado em São Paulo (1877) eram destinados às crianças ricas, enquanto que, nesse mesmo modelo, as creches serviriam as crianças pobres.

Assim, os historiadores defendem que as primeiras creches no Brasil foram fundadas na aliança de médicos e mulheres burguesas, com vistas ao atendimento do movimento higienista e ao atendimento as trabalhadoras domésticas, acentuando a divisão social entre população de origem escrava e população burguesa.

A discussão sobre a utilização das amas de leite por mulheres burguesas também vai se intensificando e vai introduzindo ideias sobre o uso de mamadeiras para alimentar os bebês. A respeito do uso de mamadeiras, verifica-se que o periódico A Mãi de Família veicula algumas ideias, sendo que, em março de 1882, publica um artigo intitulado "As Mamadeiras Envenenadas" preconizando os perigos delas para saúde das crianças e, em março do ano seguinte, publica o artigo "A Mamadeira", defendendo de forma intensa seu uso auxiliar no desmame dos bebês e em substituição as amas de leite. Mas, novamente em março de 1884, o 
jornal volta a criticar o uso das mamadeiras, publicando o artigo "Mortalidade das Crianças" (PARDAL, 2013).

Com isso, a referida autora mostra que os médicos apontaram uma única direção segura que seria a amamentação pela mãe. E não apenas indicavam os cuidados da mãe com o bebê durante o aleitamento, mas durante os primeiros anos de vida.

Nesse sentido, esclarecimentos são apontados por Kuhlmann Junior (1998) ao discorrer que uma das primeiras notícias sobre creches no Brasil foi veiculada pelo jornal $A$ Mãi de Família, dirigido às mães das famílias burguesas. No artigo, a creche era apresentada como alternativa de atendimento aos filhos das escravas que trabalhavam como empregadas domésticas. De teor preconceituoso e racista, o texto alertava sobre os perigos do convívio entre crianças filhas da burguesia e os filhos de ex-escravas. Residem aqui, as raízes da chamada creche popular.

Como podemos ver, as ações médico-higienistas marcam intensamente as relações sociais e os rumos da implantação das creches e pré-escolas no Brasil, influência que pode ser notada em diversos aspectos. "Os higienistas discutiram os projetos para construção de escolas, a implantação dos serviços de inspeção médico-escolar e apresentaram sugestões para todos os ramos do ensino, em especial com relação à educação primária e infantil” (KUHLMANN JUNIOR, 1998, p. 91).

Em 1899, foi fundado o Instituto de Proteção e Assistência à Infância do Rio de Janeiro, instituição que vai dar grande impulso ao desenvolvimento do higienismo no Brasil e entre seus objetivos constavam:

elaborar leis que regulassem a vida e a saúde dos recém-nascidos, regulamentar o serviço das amas de leite, velar pelos menores trabalhadores e criminosos, atender as crianças pobres, doentes, defeituosas, maltratadas e moralmente abandonadas; criar maternidades, creches e jardins de infância (KRAMER, 1984, p.54).

Em período histórico aproximado, com a criação do Instituto de Proteção e Assistência à Infância observou-se a abertura de creches, jardins de infância, maternidades e a realização de eventos nacionais, influenciados por exposições internacionais que tratavam de temas relacionados ao progresso técnico-científico em diversas áreas, incluindo as institucionais (KRAMER, 1984; KUHLMANN JUNIOR, 1998). 
No mesmo ano da fundação do Instituto, foi criada a creche da Companhia de Fiação e Tecidos Corcovado (RJ), a primeira creche brasileira para filhos de operários. Outras vieram posteriormente como: a da Companhia de Tecidos Alliança (RJ), a da Vila Operária Maria Zélia (1918/SP) e a da indústria Votorantin (1925/SP) (KUHLMANN JUNIOR, 1998).

A Associação Feminina Beneficente e Instrutiva foi fundada, em São Paulo, em 1901 por um grupo de senhoras, a maioria professoras, sob a direção de Anália Franco, como uma entidade destinada ao amparo e educação da mulher e da infância. Esta instituição, ao que consta, criou um Liceu Feminino para preparar professoras para as escolas maternais e para uma escola noturna para alfabetização de mulheres. As creches sob a direção de Anália Franco, ao menos inicialmente, pareciam atender em regime de internato.

O Patronato de Menores, outra instituição fundada, em 1906, no Distrito Federal por juristas brasileiros, também teve uma creche: a Creche Central. A creche foi assim batizada, pois seria exemplar para que outros institutos pudessem abrir-se em bairros mais periféricos da cidade. Também no Distrito Federal, em 1916, fundou-se a Assistência Santa Thereza, entre os diversos serviços que prestava havia uma creche diurna e o recolhimento de crianças desamparadas (KUHLMANN JUNIOR, 1998).

Como se pode notar, inicia-se a configuração dos elementos que caracterizam os serviços de creche: instituições de caráter assistencial e funcionamento prolongado, porém de atendimento à criança não mais em regime de internação.

Em 1919, os fundadores do Instituto de Proteção e Assistência à Infância implantaram o Departamento da Criança no Brasil, com intenção que este fosse assumido pelo Estado. O Departamento tinha por objetivo "o amparo a crianças e gestantes pobres, a divulgação de conhecimentos e a promoção de congressos, além do levantamento do histórico da proteção à infância no Brasil” (GEIS, 1994, p.57).

Por iniciativa do Departamento da Criança em 1922 em comemoração ao primeiro centenário da Independência, foi realizado o I Congresso Brasileiro de Proteção à Infância com vistas ao envolvimento de setores públicos e privados às questões relativas à infância. Kramer (1984) menciona que o congresso tinha como objetivo abordar temas relacionados à infância com diferentes abordagens, recebendo contribuições sociais, médicas, pedagógicas e higiênicas, tratadas de forma geral, assim como, direcionadas em relação à família, à sociedade e ao Estado. 
No entanto, é somente na década de 30 que o Estado passa a figurar como responsável por ações na área da infância, motivado por mudanças econômicas e sociais do país, com o desenvolvimento industrial da era Getulio Vargas. É criado o Ministério de Educação e Saúde o que favorece a expansão do atendimento educacional aos filhos dos trabalhadores.

Rizzini (2008) destaca que, nas três primeiras décadas do século XX, organizam-se uma série de ações de caráter médico, jurídico e filantrópico que irão embasar a Justiça e a Assistência à infância. Com o entendimento de que "educar a criança era salvar a nação; moralizá-la, civilizá-la” (p. 27), pois as crianças eram vistas como sujeitas às influências tanto do bem como do mal, ou seja, pessoas que poderiam ser moldadas ao sabor dos ventos.

Dessa forma, a autora aponta que a criança poderia ser vista como em perigo ou como perigosa, portanto, essas ações médico-jurídico-assistenciais serviriam para organizar as medidas de "prevenção, educação, recuperação e repressão" (p. 26) que se fizessem necessárias.

Com esses discursos sobre a infância, essas ações visavam a vigiar as crianças de modo que se comportassem de forma socialmente adequada e não viessem a trazer infortúnios sociais, oferecer educação de maneira a "formar" as crianças para a observância das leis e regras de convívio social ou reeducá-las, caso se desviassem do caminho educacional por algum delito e, finalmente, reprimindo aqueles que causassem danos através de comportamentos delinquentes, buscando reabilitá-los pelo trabalho.

Também durante a era Vargas, surgem outras ações na área da infância. Inicia-se a partir deste período fase Assistencial no desenvolvimento das creches no Brasil. É criado o Departamento Nacional da Criança (DNCr), ligado ao Ministério de Educação e Saúde (visava o atendimento à infância, a maternidade e a adolescência). A proposta básica era a oferta de atendimento médico, principalmente em forma de medicina preventiva entendendo que esta seria a maneira de administrar os problemas tanto das crianças quanto das famílias.

Ainda nesse período, surge o Serviço de Assistência a Menores (SAM) vinculado ao Ministério da Justiça e Negócios Interiores, que estava direcionado ao atendimento de menores de 18 anos em situação de abandono e delinquência.

Rizzini e Rizzini (2004) relatam que o SAM foi fundado em 1941 com a finalidade de assistir as crianças abandonadas, mas teve seu funcionamento comprometido por questões políticas (oportunidades para cabides de emprego) e financeiras, uma vez que, eram destinados valores mensais por cada criança atendida pela instituição. Isso fez com que o número de instituições com essa finalidade crescesse imensamente. As autoras apontam que, em 1944, 
eram 33 educandários, destes apenas quatro possuíam contratos oficiais com o SAM. E apenas uma década depois existiam 300 instituições para acolhimento das crianças desvalidas, porém em situações irregulares.

Essas práticas desvinculadas do objetivo inicial do SAM trouxeram como consequências atendimentos pouco adequados que foram motivo de muitas críticas da opinião pública, sendo vistos como "uma instituição para prisão de menores transviados e em uma escola do crime" (RIZZINI; RIZZINI, 2004, p. 34).

Procurando alterar esse cenário em que se encontrava o SAM, em 1964 é criada a FUNABEM, cujos objetivos principais era funcionar como um "Anti-SAM", operando com propostas que se opunham as da antiga instituição. Essas propostas "centravam-se na autonomia financeira e administrativa da instituição e na rejeição aos 'depósitos de menores' nos quais se transformaram os internatos para crianças e adolescentes das camadas populares” (p.35).

Nesse desdobramento e regida pelas normas da FUNABEM, cria-se, em 1973 a Fundação do Bem-Estar do Menor (FEBEM), com “objetivo de planejar e executar, no Estado de São Paulo, programas de atendimento integral ao menor carenciado, abandonado ou infrator" (GUIRADO, 1980, p. 31).

A título de exemplo do que estamos tratando, a FEBEM, além de se configurar como instituição disciplinar para menores infratores, também era uma instituição que acolhia crianças carentes ou em abandono e, passou a ser o lugar que os pais colocavam as crianças para cuidados do Estado. Segundo Guirado (1980), a maior parte da procura pelos serviços de internação para crianças na instituição era feita pelas mães (78\% dos casos).

Assim, a FEBEM atendeu crianças carentes e abandonadas até o início do ano de 1990, após essa data, manteve apenas o acolhimento de adolescentes infratores. E, ao final do ano de 2006, a FEBEM passou a ser Fundação CASA $^{1}$ (Centro de Atendimento Socioeducativo ao Adolescente).

A criação dessas instituições de assistência à infância no Brasil vai se desdobrando em diferentes frentes de atendimento, nomeados como educacionais, mas que possuem o caráter de cuidados com a infância em regime de internação (para crianças em abandono ou em infração).

Nesse sentido, Vasconcellos (2013), ao tratar das discussões sobre a infância e o papel das instituições na constituição das formas de ser criança no Brasil, afirma que "o estudo das

\footnotetext{
${ }^{1}$ Informações extraídas do website da Fundação CASA: http://www.fundacaocasa.sp.gov.br em 21/11/2014.
} 
políticas implantadas demonstra que não houve uma dicotomia entre educação e assistência, mas sim a coexistência de espaços com objetivos distintos, de acordo com a origem social da criança" (p.21).

Ainda como raízes da era Vargas, a Legião Brasileira de Assistência (LBA) foi criada em 1942 com objetivo de apoiar os pracinhas e suas famílias durante a Guerra. Entre seus objetivos estavam a organização de serviços sociais e a subvenção de instituições sociais como creches, escolas paroquiais, institutos de puericultura, além do Serviço de Assistência à Saúde e o de Assistência a Maternidade (GEIS, 1994).

Em 1943, é instituída a Consolidação das Leis do Trabalho (CLT) onde passa a haver a obrigatoriedade da implantação de creches nas empresas para que as mulheres pudessem manter seus filhos no período de amamentação. Ainda, três anos mais tarde, surgem Serviço Social da Indústria (SESI) e o Serviço Social do Comércio (SESC) que também passam a fomentar diferentes serviços, incluindo a criação de creches e pré-escolas. Esses serviços eram oferecidos como benefício ou concessão trabalhista para a mulher trabalhadora, mas não era considerado como um direito da criança.

Além disso, Merisse (1996) acrescenta que a LBA exercia influência nas diretrizes dos serviços oferecidos, tendo como proposta que o serviço social representasse promoção social, procurando se diferenciar da tradição do movimento filantrópico e religioso. Rosemberg (2006) observa que a LBA havia desenvolvido diversos programas destinados à maternidade e infância, mas sempre de caráter localizado, restrito e baseado em ações voluntárias. Entretanto, com a implantação do programa de educação pré-escolar de massa, denominado Projeto Casulo em 1976, esse cenário se altera.

Ainda em relação a LBA, é importante destacar que, a partir de 1966, o regime militar realiza intervenções na estrutura de administração e funcionamento dela, incluindo o atendimento de adolescentes em sua esfera de atuação (MERISSE, 1997).

Proferindo um discurso preventivo, com características eugênicas e de segurança nacional, o Projeto Casulo almejava proteger a nação contra as ameaças que os pobres, principalmente, os menores, considerados como infratores e delinquentes pudessem representar. Dessa forma, o projeto tinha como principal objetivo inserir as crianças pobres em creches, enquanto as mães trabalhavam como forma de evitar que ficassem sozinhas em casa ou nas ruas. 
Embora o Projeto Casulo não tivesse ambições de preparação para escolarização, contemplava atividades recreativas e, havia o propósito na direção de que estas instituições superassem o modelo de atendimento asilar e pudessem oferecer atividades de acordo com as necessidades e características de crianças de zero e seis anos. Assim, foram agregados em sua prática conhecimentos sobre:

teorias psicológicas de desenvolvimento infantil, ao valorizar a alimentação e a higiene como fatores necessários ao desenvolvimento intelectual, e, ao ver a creche como substituta materna, previa o suprimento da base afetiva para o desenvolvimento emocional da criança (GEIS, 1994, p.74).

Verifica-se que mesmo com a incorporação de outros conhecimentos a pratica do projeto, há ainda, um predomínio das preocupações com as questões de ordem higiênicas e nutricionais.

Merisse (1997) comenta que o período pós-guerra, principalmente no que tange a reconstrução dos países devastados pelas guerras, trouxe muitas mudanças no panorama político, social e econômico mundial. Para a reconstrução dos países foram criadas muitas frentes de trabalho, inclusive para mulheres. Segundo o autor, um dos movimentos sociais que vai ganhando espaço nessa conjuntura é o Movimento Feminista. Nascido nos Estados Unidos, esse movimento ganha impulso principalmente na década de 60 , abordando a discriminação contra a mulher e reivindicando direitos.

Essas discussões sociais em torno das mulheres irão contribuir para alterações importantes sobre o lugar da mulher na sociedade, transformando as relações sociais e familiares, dessa forma, alterando as concepções e as relações no âmbito do trabalho e da infância.

Assim, na década de 70, em São Paulo, aparece o Movimento de Luta por Creches. Este foi constituído pela reunião de forças de duas vertentes presentes no contexto social da época. De um lado, a presença da necessidade das mulheres das classes populares de espaço para deixarem seus filhos, uma vez que as exigências para o trabalho da mulher fora do lar eram crescentes. Por outro lado, havia a mobilização do movimento feminista, composto por mulheres provenientes da classe média, que colocava em relevo os cuidados com a infância, lutavam por alterações nos papéis sociais atribuídos a homens e mulheres e também nas próprias relações familiares. 
Merisse (1996) destaca que esse movimento será responsável pela mudança no significado da creche, dando início ao surgimento de uma instituição especializada no atendimento a criança pequena. A partir daí, a creche passa a figurar como um serviço que é um direito da criança e da mulher, atuando como um atendimento à criança complementar ao disponibilizado pela família.

Podemos notar que esse entrelaçamento das práticas institucionais para acolhimento de crianças em situação de abandono, infração ou necessidade de trabalho das mulheres vai contribuindo para o desenvolvimento de projetos educacionais de caráter disciplinar e compensatório, uma vez que, compreendem a criança como carente (econômica, social, intelectual e afetivamente), o que incide na criação dos chamados planos educacionais compensatórios.

Apesar desse modelo de educação compensatório, os movimentos feminista e de luta por creches tiveram um papel fundamental para a ampliação e melhora desses serviços, além disso, foram disparadores de transformações nas concepções e nas práticas das camadas sociais médias da população, que também passaram a exigir a criação de novos serviços de creche e outros semelhantes (MERISSE, 1997).

O autor refere que essas iniciativas levaram o Governo do Estado de São Paulo criar o Programa de Centros de Convivência Infantil para oferecer o atendimento em creches para os órgãos e repartições públicas.

Merisse (1997) acrescenta que a iniciativa privada também passa a investir na criação de creches, porém, recebem outras denominações: "hotelzinho, berçário, escolinha infantil" (p. 50). Essas iniciativas privadas se expandem, principalmente, nas décadas de 70 e 80 , batizadas de formas diferentes, procuram romper com suas condições históricas de instituições asilares para os pobres ou depósitos de crianças. Aponta que, uma nova identidade da creche "parece estar emergindo desse processo histórico mais recente, com transformações significativas na esfera da família e dos papéis sociais conforme o sexo, se caracterizaria pelo princípio de que as creches são um direito da família e da criança” (MERISSE, 1997, p.50).

Com essa argumentação entende que a creche se constituiria como uma alternativa para a família, uma vez que ofereceria cuidados e condições adequadas ao desenvolvimento infantil, contando com profissionais qualificados e ambiente físico que atenderiam ao convívio das crianças e as trocas que constituem as bases da socialização. Assim, a creche seria um espaço complementar a família, não substituindo a casa e as relações familiares. 


\section{Dos princípios... Freud: algumas considerações}

"o narcisismo coloca o eu na perspectiva do outro" 2

Como partiremos do referencial da psicanálise para pensar o desenvolvimento dos bebês, entendemos que retomar as ideias postuladas por Freud nos parece fundamental. Embora, ele não tenha se dedicado ao estudo do desenvolvimento de bebês, ao tentar descrever como ocorreria o desenvolvimento inicial do aparelho psíquico, particularmente, o desenvolvimento do ego, Freud “deixa a brecha” para pensar com ele e a partir dele.

Veremos que outros autores irão nesse sentido pensar com ele, como faz Spitz, ou a partir dele, como faz Winnicott. Esses autores guardam semelhanças e diferenças no modo de conceber o desenvolvimento dos bebês, portanto, traçar algumas considerações sobre como seria esse desenvolvimento inicial para estabelecimento das relações com o mundo pelo olhar de Freud, além de mostrar a importância de seu pensamento para o desenvolvimento da psicanálise, também contextualiza as contribuições dos outros autores que fundamentam este estudo.

Nosso entendimento, como pretendemos mostrar, é de que o conceito de narcisismo em Freud abre um modo de pensar o início da formação das relações humanas. O processo chamado narcisismo daria "start", melhor dizendo, seria ocasião de inauguração da formação de um eu para o indivíduo, assim, tornando-se condição de relação consigo mesmo e com o mundo.

Ao escrever "Sobre o Narcisismo: uma Introdução", Freud (1914) busca dar um lugar ao narcisismo no "curso regular do desenvolvimento sexual humano" (p.81). Ao buscar esse lugar, ele nos mostra como essa posição - o narcisismo - se torna condição de desenvolvimento humano. A base das argumentações iniciais de Freud nesse texto se refere a localização que a libido teria no aparelho psíquico e que estabeleceria o que ele descreveu como narcisismo.

Estudando diferentes estados patológicos, como demência precoce, parafrenias, histerias e a megalomania, Freud (1914) começa a considerar que haveria no narcisismo uma condição inicial, uma condição anterior a aquela que ele poderia verificar nas condições clínicas de seus pacientes. Isto o levou a postular a existência de um narcisismo primário, que estaria na base do estabelecimento do narcisismo secundário.

\footnotetext{
${ }^{2}$ Guirado, 2010, p.117.
} 
Segundo ele, "isso nos leva a considerar o narcisismo que surge através da indução de catexias objetais como sendo secundário, superposto a um narcisismo primário que é obscurecido por diversas influências diferentes" (FREUD, 1914, p.82).

Observa-se que Freud procura mostrar a existência de uma libido do ego que posteriormente poderia ser investida em objetos. Ele continua dizendo:

\footnotetext{
Assim, formamos a ideia de que há uma catexia libidinal original do ego, parte da qual é posteriormente transmitida a objetos, mas que fundamentalmente persiste e está relacionada com as catexias objetais, assim, como o corpo de uma ameba está relacionado com os pseudópodes que produz (FREUD, 1914, p. 83).
}

O que esse trecho parece nos mostrar é que haveria na condição primária do narcisismo um investimento original do ego em objetos, como se o ego investisse essa libido originária na busca de objetos, ele se estenderia para se ligar a algo além dele mesmo. Um movimento de extensão, de busca...

No entanto, Freud também diz que "uma unidade comparável ao ego não pode existir no indivíduo desde o começo; o ego tem de ser desenvolvido" (FREUD, 1914, p.84).

Ora, o que Freud quer dizer com isso? Primeiro assinala que há uma energia original do ego e depois diz que inicialmente não há ego e que este precisa ser desenvolvido? Pensamos que isso aponta que não há desde o início um ego em funcionamento, mas há um momento inicial onde energias disponíveis se encontram em condições de ligar-se a algo, parecem buscar algo, o que chamou de objetos.

Dessa forma, o momento do narcisismo primário indica os princípios do desenvolvimento do ego, um momento onde não há diferenciação entre um ego e as energias instintivas e nem mesmo entre essas energias psíquicas.

A esse respeito, o autor coloca que "no tocante à diferenciação das energias psíquicas, somos levados à conclusão de que, para começar, durante o estado de narcisismo, elas existem em conjunto" (FREUD, 1914, p.84).

Acompanhando o texto, isso parece fazer sentido, à medida que Freud discute as qualidades das energias psíquicas envolvidas no momento do narcisismo, há uma tentativa de discriminar quais seriam as energias envolvidas no processo de desenvolvimento do ego. 
Para que uma energia se torne libido ela precisa ser investida em um objeto, esta é a definição que Freud nos apresenta nesse texto (FREUD, 1914).

Além disso, somente quando há um investimento de energia no objeto é que será possível "discriminar uma energia sexual - a libido - de uma energia dos instintos do ego" (FREUD, 1914, p.84). Verifica-se desse modo que, Freud procura discriminar as energias psíquicas em duas.

[...] se concedemos ao ego uma catexia primária da libido, por que há necessidade de distinguir ainda uma libido sexual de uma energia não-sexual dos instintos do ego? A postulação de uma única espécie de energia não nos pouparia de todas as dificuldades que residem em diferenciar uma energia dos instintos do ego da libido do ego, e a libido do ego da libido objetal? (FREUD, 1914, p.84).

Pode-se ver que essa teoria da libido mostra-se preocupada em diferenciar os tipos de energia que estariam envolvidas nesse processo, de pronto, Freud destaca que haveria uma libido sexual e uma energia não-sexual dos instintos do ego. E, na sequência ele introduz uma libido do ego e uma libido do objeto.

Assim, ele diz que "a diferenciação da libido numa espécie que é adequada ao ego e numa outra que está ligada a objetos é o corolário inevitável de uma hipótese original que estabelecia distinção entre os instintos sexuais e os instintos do ego" (FREUD, 1914, p.85).

Basicamente, observamos que a principal função da libido é estabelecer ligação. Pensando assim, a libido pode ligar-se a objetos ou permanecer no ego. No entanto, como vimos, para que o desenvolvimento do psíquico avance é importante que a libido se ligue a objetos.

Nesse sentido, é "absolutamente necessário para nossa vida mental ultrapassar os limites do narcisismo e ligar a libido a objetos” (FREUD, 1914, p.92).

Entretanto, observando o desenvolvimento do texto, Freud abandona essa discussão sobre a diferenciação das energias psíquicas e passa a discorrer mais sobre o ponto de vista da localização da libido, seja no ego ou nos objetos.

Isso nos remete ao texto de Guirado (2010) em que discute como aspecto paradoxal o fato de que o narcisismo começa a ser descrito por Freud na perspectiva do autoerotismo, certa atenção da pessoa a si mesma (Paul Nacke), para depois tratar da libido em sua localização, orientação, ou como diz a autora, "vetoração". 
Isso vai acontecendo no momento em que procura "defender" sua teoria da libido das discordâncias com outros autores, a saber, Jung e Adler.

Guirado (2010) discute que no texto sobre o narcisismo, Freud estaria respondendo a críticas ou comentários advindos das rachaduras da comunidade psicanalítica, que talvez produziu um texto mais denso, de difícil compreensão, mas também mais aberto e indeterminado.

\begin{abstract}
Em, princípio, o desafio de responder a Jung sobre o caráter erótico da libido levou Freud não só a não subsumi-la a um interesse geral pelo mundo, como também a erotizar o ego, desde o início da vida, pela formulação de um narcisismo primário, ocasião da extensão do sujeito, como que um pseudópodo, nos objetos e coisas da realidade externa (GUIRADO, 2010, p.117).
\end{abstract}

Mais adiante, em seu texto, Guirado (2010) também dá destaque à mudança no modo como Freud fala da teoria das pulsões, comentando que ele parece anunciar uma nova teoria das pulsões, embora não parece dar-se conta disso.

\begin{abstract}
Não importam os tipos de pulsão ou energia em jogo: uma relação se construirá por efeito de uma localização inicial, originária, da libido no ego (narcisismo primário) que será ocasião de desenvolvimento da interface com o mundo e seus objetos, por meio do investimento, cada vez mais discriminado da energia sexual, neles; as ligações e/ou os afastamentos que assim se fizerem serão tomados como ações da libido do objeto (novamente, não um tipo de libido, mas uma localização dela), podendo daí decorrer um retorno da libido ao ego (narcisismo secundário) (GUIRADO, 2010, p.117).
\end{abstract}

Silva (2014) corrobora esses argumentos ao fazer uma análise do discurso do mesmo texto de Freud. Ele aponta que na interlocução com Jung, Freud não apenas mostrou a tensão que marcava a dissidência na comunidade psicanalítica, mas que essa tensão deixou marcas no desenvolvimento do conceito de narcisismo, deixando marcas dentro da própria teoria. "Nesse entrelaçamento entre o "ato de escrever" e o "escrito", as relações de poder na construção do conhecimento psicanalítico se tencionam, um conceito de narcisismo se configura, e o discurso freudiano, enquanto restringe, se prolifera" (SILVA, 2014, p.59).

$\mathrm{O}$ autor continua argumentando que Freud procurava restringir sua teoria das pulsões, ou seja, não concordava com os argumentos de Jung sobre o caráter não-sexual da libido. $\mathrm{O}$ objetivo de Freud, por assim dizer, era não alterar sua teoria, mas, Silva (2014) vai mostrando, 
em sua análise, que é isso mesmo que vai acontecendo, pois Freud vai apresentando uma teoria diferente, ao discorrer sobre o narcisismo.

[...] o conceito de narcisismo parece introduzir um modo de tratar a pulsão que dá foco a seus movimentos de localização e direção (ou seja, à sua "vetoração"), desenhando uma maneira de tratar o psiquismo (desde sua constituição) pelas relações entre o Eu e o objeto. Pensar a pulsão pela localização da libido (no Eu ou no objeto), pela sua direção, pela sua "vetoração", não abriria a possibilidade de vislumbrar uma "outra" teoria das pulsões? [...] Seria aquela cujo âmago explicativo pode repousar antes na qualidade descritiva dos conceitos. Usamos a expressão "pode repousar" precisamente para dar destaque ao fato de que esta proposição não está explicita no texto de Freud - mas sim nas aberturas do discurso [...] (SILVA, 2014, p. 119).

Nessa mesma linha de raciocínio, Freud segue o texto discorrendo sobre a localização da libido, mas agora, trará o foco de seus argumentos para a hipocondria e a localização ou direção da energia psíquica para o corpo.

Após essa exposição, Freud dará atenção como o narcisismo pode lançar luz à vida amorosa dos seres humanos em que passa a discorrer sobre como se daria esse processo nas crianças pequenas.

Freud observa que as primeiras relações de objeto nas crianças se darão em relação as experiências de satisfação, ou melhor, das relações com as pessoas que estabelecem os primeiros cuidados é que derivam os objetos sexuais das crianças.

\begin{abstract}
As primeiras satisfações sexuais auto-eróticas são experimentadas em relação com funções vitais que servem à finalidade de autopreservação. Os instintos sexuais estão, de início, ligados à satisfação dos instintos do ego; somente depois é que eles se tornam independentes destes, e mesmo então encontramos uma indicação dessa vinculação original no fato de que os primeiros objetos sexuais de uma criança são as pessoas que se preocupam com sua alimentação, cuidados e proteção; isto é, no primeiro caso, sua mãe ou quem quer que a substitua (FREUD, 1914, p.94).
\end{abstract}

A isso, Freud (1914) acrescenta que se pode falar que esse tipo de escolha de objeto pode ser chamado de anaclítico ou de ligação. A partir dele, sugere que pode ocorrer de encontrarmos, de acordo com o tipo de escolha de objeto, relações do tipo anaclítica ou do tipo narcisista.

Outro argumento a favor do narcisismo primário nas crianças seria considerar a própria atitude dos pais em relação a seus filhos. A esse respeito, Freud (1914) diz que diante da "atitude 
de pais afetuosos para com os filhos, temos que reconhecer que ela é uma revivescência e reprodução de seu próprio narcisismo" (p.97).

Nesse sentido, Freud (1914) coloca que os pais procuram atender às necessidades das crianças que eles julgam essenciais, buscam divertimento e evitam as privações e infortúnios que eles próprios possam ter vivido. Enfim, a criança receberá os cuidados de "Sua Majestade o Bebê", o que está na base daquilo que os pais imaginam de melhor e ideal para seus filhos. A isso, se daria o ponto de contato com o próprio narcisismo dos pais, renascido no contato amoroso com os filhos.

Outro ponto considerado no texto sobre o Narcisismo diz respeito à formação de um ideal de ego. Este seria de acordo com Freud responsável pela censura, pela repressão aos aspectos instintivos a partir do contato com a cultura.

O autor diz que "o narcisismo do indivíduo surge deslocado em direção a esse novo ego ideal, o qual, como o ego infantil, se acha possuído de toda perfeição de valor" (FREUD, 1914, p.100).

Isso remete a pensar novamente com a ideia de direção, de "vetoração", mas agora o narcisismo seria direcionado para uma imagem de si, que é buscada como o ideal. Ainda mais adiante, aponta para a formação de um "agente psíquico especial" (superego) que seria responsável pela regulação entre a satisfação narcisista e certa vigilância do ego, aferida pela régua do ideal.

\footnotetext{
Assim, dos primeiros investimentos na relação com o mundo até a criação de uma censura a reprimir o ego real, em princípio onipotente, temos a ação da libido, ora localizada no ego, ora localizada no objeto, ou seja, temos a ação do narcisismo, esse modo de funcionar que da erotização do ego parte para erotização das relações e para o manejo de uma censura voltada para si, apoiada em imagens, representação da relação, identificações (GUIRADO, 2010, p.119).
}

Com esse excerto, intenta-se mostrar que na base da ideia de narcisismo encontra-se as raízes do estabelecimento das relações humanas, visto que é a partir de um modo de ser ou estar narcísico é que o desenvolvimento do ego vai se constituindo em contato com a realidade, ao mesmo tempo se torna condição de relação com pessoas e com o mundo. Como iniciamos... “coloca o eu na perspectiva do outro"... 


\section{O desenvolvimento do bebê no primeiro ano de vida na perspectiva de Spitz}

Optamos em incluir neste estudo algumas ideias de René Spitz por compreender que ele foi um estudioso do desenvolvimento que trouxe contribuições importantes, pensando as relações das mães e bebês como fundantes das relações com o mundo, mas também por seus estudos do desenvolvimento psicológico de crianças em instituições, principalmente, hospitais e creches. Portanto, entendemos que seu pensamento poderá auxiliar nossa compreensão e o desenvolvimento deste nosso estudo.

A fim de situar o autor no âmbito de nosso estudo, entendemos ser necessário contextualizar o trabalho de Spitz e descrever como e onde foram feitos os estudos em questão. Para que, na sequência possamos apresentar suas principais ideias sobre o desenvolvimento de bebês.

Trataremos de mostrar as ideias desenvolvidas principalmente, no texto $O$ primeiro ano de vida. Neste texto, o autor esclarece que utilizou o método longitudinal de observação complementando com estudos transversais, acompanhando crianças por um período de dois anos a dois anos e meio. Realizaram mensalmente testes de personalidade, fizeram numerosos experimentos e observaram crianças, de forma individual, por um tempo de 4 horas diárias, em média. As informações colhidas foram protocoladas e formaram o histórico de caso de cada sujeito.

Spitz (1983) introduziu o que chamava de "análise através de filmes" para obter um registro objetivo e permanente das observações e impressões visuais, para que pudessem repetir, comparar e analisar determinados fenômenos do comportamento dos bebês. Menciona que procurou filmar as crianças logo após o nascimento, em alguns casos chegou a filmar o próprio parto da criança. Além disso, se preocupou em filmar também os comportamentos que se desviavam do comportamento médio esperado das outras crianças no mesmo momento de desenvolvimento.

Com intuito de pensar as discussões em torno de influências das diferenças culturais e raciais, foram incluídas crianças com diferenças étnicas e culturais. Além disso, para estudar um número grande de crianças e assegurar o aspecto de constância ambiental, os estudos foram realizados em duas instituições que chamou de Creche e Casa da Criança Abandonada (SPITZ, 1983). 
As instituições escolhidas possuíam estruturas físicas semelhantes e apresentavam condições de cuidados de higiene e profissionais considerados adequados. O cuidado com os bebês recém-nascidos era o mesmo em ambas as instituições, pois eles eram mantidos em berçário especial e ficavam isolados dos bebês mais velhos. Somente após completarem dois ou três meses os bebês eram transferidos para o espaço dos bebês mais velhos e mantidos em "cubículos individuais" 3(SPITZ, 1983, p.43).

Havia algumas diferenças entre as instituições, na Creche, passados seis meses os bebês eram transferidos para quartos contendo de quatro a cinco berços cada um e, na Casa da Criança Abandonada os bebês permaneciam nos cubículos até quinze ou dezoito meses.

Também são descritas diferenças na ambientação das instituições no que se refere à iluminação e utilização de cores na pintura dos prédios. Mas, em relação aos cuidados com alimentação e atendimento médico os cuidados eram equivalentes e adequados. Ainda, quanto à alimentação, descreve que grande parte dos bebês mais novos era amamentada ao peito em ambas as instituições, porém na Creche essa forma de alimentação parecia diminuir e a mamadeira era introduzida, o que levava a criança a deixar de mamar no peito. Na Casa da Criança Abandonada, os bebês eram amamentados ao peito até os três meses de idade.

A finalidade das instituições onde os bebês eram acolhidos também diferia. A Creche era uma instituição penal para adolescentes delinquentes grávidas e os bebês eram acolhidos desde o nascimento até um ano de idade. Já, a Casa da Criança Abandonada recebia crianças, cujas mães não possuíam condições de sustento para si mesmas e seus filhos.

As particularidades de cada instituição não se limitavam à finalidade, também se estendia aos cuidados com as crianças. Assim, a Creche possuía capacidade de atender de 40 a 60 crianças de cada vez e funcionava com uma enfermeira-chefe e cinco assistentes. Essas profissionais tinham por objetivo transmitir às jovens mães a noção de cuidados, tanto de higiene como com os bebês, supervisionando e aconselhando nesses cuidados.

Dessa forma, as crianças da Creche eram cuidadas por suas próprias mães e, se por algum motivo isso não fosse possível, a mãe era substituída por outra mãe ou por uma jovem grávida, que assim, poderia adquirir experiência de cuidados para seu futuro bebê.

A Casa da Criança Abandonada recebia crianças de duas maneiras: crianças filhas de mulheres casadas e sem condições de sustento, e crianças filhas de mulheres solteiras (mães

\footnotetext{
${ }^{3}$ Spitz descreve esses cubículos como completamente fechados por vidro na Creche e fechado por vidro, em três lados e um dos lados abertos na Casa da Criança Abandonada.
} 
solteiras), estas, deveriam permanecer na instituição cuidando de seu próprio filho e de mais uma criança do abrigo, além de auxiliar no preparo e distribuição da alimentação dos bebês maiores, durante um período de três meses. Embora não haja referência à capacidade de atendimento dessa instituição, essa casa também era regida pelas mesmas condições profissionais, uma enfermeira-chefe e suas assistentes.

Após o período de três meses, esses bebês eram cuidados pelas cinco enfermeiras assistentes, em uma proporção de uma enfermeira para sete bebês. O que na prática ficava reduzido, pois as enfermeiras tinham que se dividir entre outras tarefas que não apenas os cuidados com os bebês. Isso afetava diretamente o tipo de cuidado, exemplar disso, eram as mamadeiras deixadas fixas aos berços e os lençóis ou cobertores pendurados nos berços de modo a ocultar a visão da criança para o ambiente ao redor, "colocando-a em confinamento solitário, deixando visível apenas o teto. Como consequência disso, os bebês permaneciam deitados de costas por muitos meses, formando uma espécie de concavidade em seus colchões, fora da qual eram incapazes de se virar" (SPITZ, 1983, p.46).

Outra característica que divergia entre as instituições era a existência de brinquedos à disposição das crianças. Na Creche, havia ao menos um brinquedo ao alcance da criança e a possibilidade de estabelecer contato visual com o ambiente, pois os cubículos de vidro favoreciam que elas fizessem contato com as outras crianças e com os adultos que estavam em atividades no ambiente, ou seja, as mães ou demais mães conversando entre elas ou cuidando e brincando com seus bebês. Em oposição a isso, a Casa da Criança não possuía brinquedos e nem a possibilidade de contato visual.

Feita a apresentação do contexto de estudo no qual o autor utilizou como fonte para o desenvolvimento de seu pensamento sobre o desenvolvimento de bebês durante o ano inicial de vida, passaremos a tratar mais especificamente do âmbito das ideias, ou seja, como Spitz descreveu e concebeu o desenvolvimento dos bebês.

Anna Freud, no prefácio de $O$ primeiro ano de vida, começa esclarecendo que Spitz se posiciona de forma diferente em relação aos métodos de estudos utilizados, bem como, se diferencia também em relação a compreensão de outros psicanalistas de que o bebê ao nascer já seria capaz de estabelecer uma relação objetal com mãe. Ela nos diz que Spitz: 
estruturas sucessivas, isto é, processos psicológicos que emergem progressivamente dos protótipos fisiológicos que lhe são subjacentes (FREUD, 1887, p. VIII)

Nessa perspectiva, o bebê ao nascer ainda não é capaz de estabelecer relações com a mãe ou com o mundo, mas a partir de um relacionamento inicial com a mãe e um gradual e progressivo avanço fisiológico possibilitam o surgimento dos primeiros processos psicológicos no bebê. Vejamos, então, o que Spitz nos contará a respeito.

René Spitz (1983) começa nos dizendo que seus estudos psicanalíticos têm as raízes nos estudos de Freud e, com os conceitos por ele postulados é que fará suas observações das crianças e desenvolverá suas ideias sobre as relações de objeto. E, como essas relações são fundamentais para a sobrevivência e para o desenvolvimento dos aspectos psíquicos e somáticos da personalidade.

\begin{abstract}
A maior parte do primeiro ano de vida é dedicado ao esforço de sobrevivência e à formação e elaboração dos instrumentos de adaptação necessários a esse objetivo. A cada momento, Freud lembra-nos que a criança, durante este período de sua vida, é indefesa e incapaz de sobreviver por meios de seus próprios recursos. O que falta a uma criança é compensado e fornecido pela mãe. Esta propicia a satisfação de todas as suas necessidades. O resultado é uma relação complementar, uma díade (SPITZ, 1983, p.23).
\end{abstract}

O que Spitz nos comunica é que o bebê, ao nascer, não pode sobreviver por seus próprios recursos, ele depende de cuidados de outra pessoa para que suas necessidades mais básicas, como as de sobrevivência sejam asseguradas, mas, ele precisa de algo mais, precisa de uma relação complementar ${ }^{4}$, precisa formar uma relação a dois.

Com essa relação complementar se estabelecendo, o bebê poderá desenvolver o seu potencial e ir se tornando independente desta díade ou do ambiente. Mostrando que tanto o desenvolvimento somático quanto psicológico "são essencialmente dependentes do estabelecimento e progressivo desdobramento das relações objetais, cada vez mais significativas, isto é, das relações sociais" (SPITZ, 1983, p.24).

O autor ainda nos esclarece que seu pensamento se baseia no conceito de indiferenciação postulado por Freud, compreendendo o bebê recém-nascido como um organismo indiferenciado, com um equipamento congênito e certas tendências (anlagen). Portanto, Spitz

\footnotetext{
${ }^{4}$ Grifo meu.
} 
(1983) compreende o bebê como uma totalidade indiferenciada e que as diversas funções, estruturas e impulsos instintivos irão se diferenciar a partir desta totalidade.

E para que essa diferenciação aconteça o bebê contará com dois processos: maturação e desenvolvimento. Nesse contexto, maturação diz respeito ao processo de desdobramento das funções inatas da espécie humana, que tem seu curso no desenvolvimento embrionário ou após o nascimento, caracterizam-se pelo desenvolvimento das tendências e se manifestam nos estágios posteriores da vida. Enquanto o desenvolvimento é descrito como "a emergência de formas, de função e de comportamento, que constituem o resultado de interações entre o organismo, de um lado, e o ambiente interno e externo, de outro" (SPITZ, 1983, p.25).

O apontamento desses elementos se faz importante para mostrar que nessa perspectiva do estado de não-diferenciação inicial do bebê não existe ego, assim, falar em complexo de édipo ou superego nos momentos iniciais de vida do bebê não faz sentido. Assim como, ainda não há notícias de simbolismo, pensamento simbólico e interpretações simbólicas.

Além disso, parece importante destacar que "os processos psíquicos e orgânicos se entrelaçam; mas eles não são dois aspectos diferentes de um mesmo fenômeno, eles são complementares" (SPITZ, 1979, p. 41).

Nesse sentido, o interesse do autor recai sobre a origem das primeiras relações objetais, melhor dizendo, das primeiras relações que se estabelecem entre a mãe e seu bebê. Intenta em nos mostrar como um bebê passa do estado de não-relacionamento, para um outro, no qual o bebê está em relacionamento com a mãe.

E para que seja possível compreender o que nos diz, Spitz (1983) começa fazendo uma diferenciação entre a mãe e o bebê, chamando atenção para a diferença entre a condição psíquica da mãe (considerada desenvolvida) e a do bebê (em desenvolvimento), dessa forma, uma relação considerada assimétrica a medida que a contribuição de cada um para um relacionamento mútuo também será desigual

Destaca, também, a diferença em relação ao ambiente na perspectiva do adulto e do bebê. Enquanto para um adulto ou a mãe o ambiente é constituído de objetos e inúmeras pessoas, além das possibilidades de variações no tipo e dinâmica de relações que podem se estabelecer entre o adulto, as pessoas e os objetos no mundo.

O mesmo não acontece com o bebê, para ele o ambiente "consiste, por assim dizer, em um único indivíduo, a mãe ou um substituto dela. Mesmo este único indivíduo não é percebido, 
pelo recém-nascido, como uma entidade distinta de si mesmo. É simplesmente parte da totalidade de suas necessidades e de suas satisfações" (SPITZ, 1983, p.31).

Esse ambiente que é a mãe está inserido na realidade, no mundo, tal como o conhecemos concretamente e as notícias desse mundo serão transmitidas ao bebê pela mãe ou por aquele que cuida e satisfaz suas necessidades.

Sendo assim, durante os primeiros meses de vida, o bebê em desenvolvimento e sua mãe ou seu meio ambiente se constituem no que o autor chamou de "sistema fechado", formado pela mãe e seu filho. Ocorre que essa situação vai se alterando ao longo do primeiro ano de vida do bebê, à medida que se estabelecem as relações objetais, que "são as relações entre um sujeito e um objeto. Em nosso caso particular, o recém-nascido é o sujeito" (SPITZ, 1983, p.32).

Lembrando que o bebê encontra-se em estado de não-diferenciação, portanto, não há presença de psique ou funcionamento psíquico estabelecidos, bem como, não há objetos nem relações com objetos. O desenvolvimento destes dar-se-ão de forma progressiva, ao longo do primeiro ano de vida, inclusive onde haverá o estabelecimento do objeto libidinal.

Para Spitz (1983) para que seja possível o estabelecimento do objeto libidinal, três estágios estão envolvidos neste desenvolvimento:

1) O estágio pré-objetal ou "sem objeto"

2) O estágio precursor do objeto

3) O estágio do próprio objeto libidinal

Discorreremos sobre cada um desses estágios para mostrar como o desenvolvimento do bebê passa por alterações importantes ao longo do tempo até constituir uma relação diferenciada com a mãe.

Antes, porém, faz-se necessário ressaltar outro elemento importante no pensamento e desenvolvimento das ideais do autor. Verifica-se que, Spitz (1983) considera que o desenvolvimento do bebê, durante o primeiro ano de vida, não ocorre de forma linear, a cada etapa do processo ocorrem mudanças que respondem pelo surgimento de novos aspectos e capacidades no bebê. 
A essas etapas ou estágios correspondem alterações de "um determinado nível de desenvolvimento para o nível superior seguinte", este nível é marcado por diferenciações cada vez mais elaboradas do ponto de vista do desenvolvimento psíquico (SPITZ, 1983, p.114).

Em outro texto, Spitz (1979) assinala que a cada novo estágio de desenvolvimento surge um determinado componente afetivo, o qual considera como um indicador ${ }^{5}$ de novos processos em curso. Sendo possível observar que a influência do desenvolvimento psicológico sobre o comportamento do bebê é crescente nos três diferentes estágios ou indicadores.

O autor aponta, dessa maneira, que os critérios que utiliza na escolha nos indicadores são de natureza psicológica, portanto, discorre que os três organizadores da psique são manifestações de afetos (SPITZ, 1979).

A esse período crítico em que as alterações no desenvolvimento se integram umas com as outras, assim como, surgem novas funções e capacidades resultantes do processo de maturação. A resultante dessa integração é uma reestruturação psíquica em nível mais elevado de complexidade (SPITZ, 1960, 1979, 1983). A essa integração é que chamará de "organizador" da psique. Consideram-se três "organizadores" da psique:

a) Primeiro organizador: Reação de sorriso

b) Segundo organizador: Ansiedade dos oito meses

c) Terceiro organizador: O domínio do "Não" (gesto e palavra)

\section{O estágio pré-objetal}

A fim de facilitar o entendimento sobre o que vem a ser objeto libidinal iremos recorrer ao caminho que próprio Spitz utiliza ao empregar a definição descrita por Freud em O instinto e suas Vicissitudes (1915):

O objeto de um instinto é a coisa em relação à qual ou através da qual o instinto é capaz de atingir sua finalidade. É o que há de mais variável num instinto e, originalmente, não está ligado a ele, só lhe sendo destinado por ser peculiarmente adequado a tornar possível a satisfação. O objeto não é necessariamente algo estranho:

\footnotetext{
${ }^{5}$ Grifo nosso.
} 
poderá igualmente ser uma parte do próprio corpo do indivíduo. Pode ser modificado quantas vezes for necessário no decorrer das vicissitudes que o instinto sofre durante sua existência; sendo que esse deslocamento do instinto desempenha papéis altamente importantes. Pode acontecer que o mesmo objeto sirva para a satisfação de vários instintos simultaneamente [...] (FREUD, 1915, p 128).

A partir dessa definição podemos dizer que objeto libidinal não é tanto um objeto em si, mas ele se caracteriza mais por ser o alvo, melhor dizendo, por ser o objeto encontrado por um instinto que busca satisfação. $\mathrm{O}$ instinto se liga ao objeto por encontrar nele características ou condições de atendimento de uma satisfação. Ao atender à necessidade expressa instintivamente o objeto torna-se libidinal, dessa forma, a característica fundamental de um objeto libidinal é seu caráter variável, mutável, possibilitado pela possibilidade de deslocamento instintual. É, em função disso, que um mesmo objeto pode atender a diferentes instintos.

Aproveitamos a ocasião para adicionar mais um esclarecimento para nos mantermos em coerência com o pensamento de René Spitz. Em relação ao uso do termo instinto, ele prefere o termo impulso (drive), o que foi colocado entre parênteses na edição pela Stantard, a qual se utiliza do termo instinto.

Sobre isso, Spitz (1983) argumenta que o termo original usado por Freud em alemão é Trieb mais do que Instinkt, além da ampla utilização deste último em biologia com definição diferente da empregada por Freud em seus estudos. Acrescenta-se a isso, o fato da palavra não possuir correspondência na língua inglesa, por isso, traduzida como Instinto, no entanto, essa tradução pode caminhar as margens do sentido empregado pelo termo Trieb.

Então, com intuito de reduzir os impactos da discordância de tradução e compreensão da ideia, Spitz (1983) sugere o uso da expressão impulso instintivo, ao invés de instinto.

Dito isso e, já de posse do conceito de objeto libidinal, então o que vem a ser o estágio pré-objetal?

O estágio pré-objetal ou de ausência de objeto é um momento de não-diferenciação, pois nesse estágio o bebê não é capaz de distinguir os objetos uns dos outros, não consegue distinguir os objetos de seu próprio corpo e não percebe o mundo ao seu redor como separado dele. Este corresponderia de forma aproximada com o período do narcisismo primário (SPITZ, 1960, 1983). 
Segundo o autor, "no estágio de não diferenciação, não há distinção clara entre psique e soma, entre interno e externo, entre impulso e objeto, entre "eu" e "não-eu", e nem mesmo entre diferentes regiões do corpo" (SPITZ, 1983, p.49).

Assim, mediante o contato com o corpo materno ou objetos o bebê não os percebe como algo separado ou diferente de si e, sim como parte de si mesmo. Além disso, o bebê ainda não está diferenciado, nem mesmo organizado em relação aos aspectos orgânicos, tais como, aspectos neurológicos e musculares.

Spitz (1983) discorre que durante as primeiras semanas de vida o bebê ainda não possui um sistema perceptivo ativo, mas protegido dos estímulos ambientais, o que se altera, gradativamente, com o tempo. Nesse período em que haveria uma barreira de proteção aos estímulos ambientais, toda a percepção do bebê passaria por aquilo que chamou de sistema interoceptivo. De acordo com esse sistema,

[...] as respostas, manifestadas pelas crianças são originadas em função da percepção de necessidades que lhe são comunicadas por este sistema. Os estímulos provenientes do exterior são somente percebidos quando ultrapassam o limiar de percepção, irrompendo na quietude em que está mergulhado o recém-nascido que, então, reage com desprazer (SPITZ, 1960, p. 30).

Desta forma, podemos verificar que as reações da criança a partir das percepções do próprio corpo, podendo ser fome, frio, desconforto corporal, dor entre outros, são proporcionadas pelo sistema interoceptivo. A partir dessas percepções a criança sairia de um estado de quietude para um estado de excitação.

É um estado de excitação, que parece ter o desprazer como matiz. Irei mais longe: durante as primeiras horas e os primeiros dias de vida, o matiz de desprazer é o único afeto que pode se observar; sua contrapartida é, não o prazer, mas a quietude. Este é um modo de funcionamento apoiado em linhas estritamente fisiológicas. O funcionamento psicológico deverá se desenvolver [...] (SPITZ, 1960, p.31).

Essa alternância entre momentos de quietude e excitação corresponderia, segundo o autor, ao princípio do nirvana postulado por Freud, que consiste na tendência a reduzir as tensões. Estaria na base do funcionamento psicológico que irá se desenvolver ao longo do tempo (SPITZ, 1960 e 1983). 
O que vai se desenhando com a discussão do sistema perceptivo do bebê é que inicialmente, parece haver uma ênfase na sensorialidade do bebê. A ideia é que o bebê vai percebendo o mundo aos poucos, a medida do desenvolvimento psíquico mais rudimentar é a medida do desenvolvimento perceptivo-sensorial do bebê. Dessa forma, “todo estímulo deverá ser primeiro transformado em uma experiência significativa; somente então ele pode tornar-se um signo ao qual outros signos são acrescentados, gradativamente, para construir a imagem coerente do mundo da criança" (SPITZ, 1983, p.54).

Assim, vamos mostrar os aspectos perceptivos envolvidos e necessários para o desenvolvimento psíquico inicial do bebê. Spitz (1983) destaca 5 fatores envolvidos no sistema perceptivo-sensorial do bebê.

A barreira do estímulo é o primeiro fator, responsável pela proteção da maioria dos estímulos ao qual a criança está exposta, então, em primeiro lugar as estações receptoras nos recém-nascidos ainda não estão em atividade e, segundo, ela passa a maior parte do dia dormindo, o que também a protege dos estímulos do ambiente. Com o passar dos meses, a capacidade do bebê para receber os estímulos vai aumentando, ao mesmo tempo em que a capacidade da criança para ação voluntária também.

O segundo fator se relaciona ao primeiro, com a crescente capacidade perceptiva e, também, de forma gradual, começa um processo de atribuir significado aos estímulos. O ambiente entraria como o terceiro fator, pois a mãe ao cuidar do bebê o protege contra uma quantidade muito intensa de estímulos externos, pois ela evita muito barulho, aquece o bebê, o protege do excesso de luz etc.

No quarto fator, a mãe também cuida dos aspectos que se relacionam aos estímulos internos, alimentando, trocando, observando o desconforto corporal, o que proporciona ao bebê descarregar a tensão.

E, no quinto e último fator, apontado como o mais importante para a construção da imagem de mundo pela criança é proporcionado pela "reciprocidade entre mãe e filho", o que também foi chamada de diálogo. Entendida como uma forma de interação entre a mãe e a criança, com um clima emocional específico e que se caracterizaria por um "ciclo de açãoreação-ação que torna o bebê capaz de transformar gradualmente os estímulos sem significado em signos significativos" (SPITZ, 1983, p. 55).

O que parece despontar a partir desses enunciados é que o bebê, pela sensorialidade, aqui colocada em termos perceptivos, vai em relação com a mãe construindo uma imagem de 
mundo, pela vivência de experiências de contato com o próprio corpo e suas sensações e, ao mesmo tempo, com o ambiente, com corpo e as experiências advindas do fazer ou dos cuidados maternos.

Nas palavras do autor "não estamos inclinados a falar de percepção no bebê enquanto os estímulos que incidem sobre o mecanismo sensorial e são processados centralmente não se tenham tornado significativos por meio da experiência do bebê" (SPITZ, 1983, p. 55).

O que o autor parece querer comunicar que a princípio o bebê não tem percepção, mas aos poucos e no decorrer do tempo, apoiado no processo de maturação e desenvolvimento, poderá elaborar estas experiências sensoriais em contato com a mãe ou cuidador, o bebê passa a atribuir sentido as vivências de seu próprio corpo, somente então, poderemos falar em percepção, como resultado desse processo de repetidas experiências sensoriais que se constroem como memórias e ganham significado por meio das experiências e da relação com o ambiente.

Assim, pode-se dizer que "o sistema perceptivo, o sensório do bebê" está em transição, está em desenvolvimento, por isso, assume formas diferentes de funcionamento (SPITZ, 1983, p.128).

Para Spitz (1983), antes que a percepção esteja funcionando como tal, o bebê operaria através do que ele denominou de organização cenestésica. Esse sistema de sensações extensas, principalmente de natureza visceral, que estariam relacionadas ao sistema nervoso autônomo e, manifestam-se basicamente em forma de emoções.

Esse sistema de organização cenestésica, também chamado de recepção cenestésica não é localizado, muito menos discriminado, sendo caracterizado por seu aspecto extensivo. Relaciona-se menos com os aspectos sensório motores e mais com os aspectos de sensibilidade profunda e em termos de totalidade, de modo absoluto, um tipo de resposta tudo-ou-nada. São exemplares desse sistema de organização cenestésica as categorias: "equilíbrio, tensão (muscular ou outra), postura, temperatura, vibração, contato da pele e corporal, ritmo, intervalos, duração, tom, timbre, ressonância, rumor” entre outras (SPITZ, 1983, p.129).

Dizendo de outro modo, essa sensibilidade profunda é captada pelo sistema sensório do bebê, seriam, portanto as sensações experimentadas pelo bebê em contato com o seu próprio corpo e com o ambiente, para as quais ainda não existe um sistema de signos ou representações.

Ressalta-se ainda que, em contraste com a organização cenestésica encontra-se o que chamou de organização diacrítica. Esse sistema mais desenvolvido de percepção processa-se 
por órgãos periféricos dos sentidos, sendo de tipo localizada, circunscrita e intensiva, tendo o seu centro no córtex, portanto, manifestando-se por processos cognitivos, entre os quais os processos de pensamento. A característica principal da organização diacrítica é a "percepção através do sensório" (SPITZ, 1983, p. 129).

Pode-se notar, então, que, no começo da vida do bebê o sistema perceptivo não está organizado tal como nos adultos, ao contrário, essa organização vai se estabelecendo ao longo do tempo, de acordo com o amadurecimento do bebê e com as experiências com o próprio corpo e com o ambiente. Dessa forma, o desenvolvimento da capacidade de percepção no bebê se inicia com a organização cenestésica e evolui para a organização diacrítica, que seria a forma de percepção mais elaborada, como poderemos notar. Entretanto, é importante ressaltar que a organização cenestésica não desaparece, mas se mantém como um sistema perceptivo de base, não consciente como a percepção diacrítica.

Outro ponto fundamental diz respeito ao caráter transicional pertencente ao desenvolvimento desses processos perceptivos no bebê, ou melhor, há algumas zonas do corpo e órgãos sensoriais que funcionariam como elementos facilitadores da transição da percepção interno e externo.

\footnotetext{
Parece existir na criança, ao nascer, certas zonas e órgãos sensoriais que considero transicionais, servindo de mediadores entre os órgãos sensoriais periféricos e os viscerais, entre o interior e o exterior. Descrevi um deles, a região oral, que se estende, de um lado pela laringe, faringe, palato, língua e interior das bochechas e, por outro lado, inclui os lábios, o queixo, o nariz e a parte externa da superfície da bochecha em uma palavra, o "focinho" (SPITZ, 1983, p.56).
}

Essa citação possibilita compreender que, por um lado, essas duas formas de organização perceptiva, embora diferentes se apresentam complementares no desenvolvimento do sistema de percepção do bebê. Por outro lado, ao destacar o caráter transicional das zonas ou órgãos sensoriais, o autor parece sinalizar a importância da transição da organização cenestésica para a organização diacrítica, mas com isso, sinalizar que há uma transição do modo de percepção, que vai estabelecer as bases para o início do processo de discriminação. Aqui, parece apontar para as raízes do processo de diferenciação no bebê.

Vamos prosseguir com os argumentos do autor sobre o desenvolvimento desses processos no bebê para que se torne inteligível os caminhos pelos quais o bebê alcança ou 
constitui o objeto libidinal. Veremos que esse é um percurso delicado e muito complexo, que vai se construindo aos poucos e em pequenos passos...

Spitz (1983) defende a posição de que para que esse sistema perceptivo comece a se organizar dois fatores precisam estar presentes ao mesmo tempo e combinar-se: o bebê com sua necessidade e alguém que atenda essa necessidade. Dessa maneira, o bebê sente fome, sua necessidade é ser alimentado, portanto, uma necessidade que nasce no interior do organismo, um estímulo de origem proprioceptiva e a mãe que amamenta o bebê, oferecendo o seio, um estímulo externo, que o bebê poderá associar com a satisfação de sua necessidade.

Acrescenta-se a isso, que todas as vezes que a mãe se apresenta para cuidar do bebê, seja amamentando ou realizando qualquer outro tipo de cuidado, o rosto humano é o que o bebê vê. Esse contato repetido incontáveis vezes e por tempo prolongado favorecem que o bebê além de associar a mãe à satisfação de suas necessidades, também visualize seu rosto e estabeleça troca de olhares com ela, pois o bebê fixa seu olhar na face materna de modo contínuo. Assim, ele pode ver e ser visto por ela! Como o próprio autor comenta,

[...] sempre oferecemos nossa face diretamente à inspeção da criança, fitando-a nos olhos, movendo nossa cabeça e, na maioria das vezes, dizendo alguma coisa. Isto significa que a face, tal como se apresenta, é o estímulo visual mais frequentemente oferecido ao bebê, durante os primeiros meses de vida. No decorrer das primeiras seis semanas de vida, um traço mnemônico da face humana é estabelecido na memória infantil, como primeiro signo da presença de uma satisfação das necessidades. O bebê acompanhará com os olhos todos os movimentos deste signo (SPITZ, 1983, p.62).

Nesse ponto, o autor nos faz notar que nesse período inicial de vida em que predomina a não-diferenciação, o atendimento das necessidades do bebê tem um lugar fundamental no desenvolvimento da percepção. Entendidas como experiências de prazer e desprazer, as necessidades passam a configurar o campo dos afetos. Sendo assim, dois elementos já se encontram em desenvolvimento no bebê, por assim dizer, o estabelecimento dos processos de percepção e os afetos, que nesse momento de não-diferenciação permanecem como um só.

Esclarece-se que por afetos ou aspectos emocionais, Spitz (1983) entende os momentos de excitação e quietude vividos pelo bebê, nos intervalos entre o surgimento da necessidade (excitação) e a satisfação da necessidade (quietude), como os precursores do desenvolvimento psíquico. E, também denominou de afeto de desprazer e afeto de prazer. 
A essa altura, alguém pode perguntar, como essa discussão sobre o processo rudimentar da percepção e dos afetos no início de vida do bebê se relaciona com o estágio sem objeto? E como isso se associa ao desenvolvimento relacional do bebê?

Podemos dizer que Spitz realizou pesquisas e estudos de comportamentos que poderiam ser observáveis e comparáveis em bebês recém-nascidos para demonstrar como ocorre o desenvolvimento primevo dos bebês. E, para poder discutir "como" e "o que" o bebê percebe, procurou se colocar na "situação subjetiva do bebê" para relacionar com os dados observados (SPITZ, 1983, p.64).

Dessa forma, procurou demonstrar como o início da vida de um bebê é um período de preparação com rudimentos de integração de experiências sensoriais que visam a colocar o bebê em contato. Em contato com essas experiências sensoriais e em contato com a mãe ou substituto, os primórdios de relação com o mundo.

Para que o bebê possa constituir o objeto é preciso que dele se dê conta, para tanto, precisa tornar o objeto como algo diferente de si, o que irá envolver a capacidade sensorial do bebê. Assim, partimos das sensações proprioceptivas (de dentro do próprio corpo) para o início da percepção por contato (corporal) e percepção à distância (visual e auditiva).

Entretanto, essas primeiras sensações visuais no bebê são de caráter generalizado, extensivo e não localizado como as sensações cenestésicas, não se diferenciando destas. Mas, há uma região perceptiva que funciona com maior especificidade desde o nascimento, esta região é a boca e a cavidade oral (SPITZ, 1983).

O autor menciona que há no bebê um reflexo de enraizamento "que consiste na rotação da cabeça em direção ao estímulo, seguido por um movimento de estalar a boca" em situações onde a região externa da boca é estimulada (SPITZ, 1983, p.70).

A hipótese sustentada por ele é de que este comportamento é inato e com valor de sobrevivência e, seria o menos inconstante quando comparado com outros, além disso, quando combinado com o reflexo de sucção constituiria o único comportamento dirigido do bebê recém-nascido.

A cavidade oral, na perspectiva da percepção, incluindo a língua, lábios, face, faringe e nasofaringe, é dotada tanto de sensações interoceptivas quanto exteroceptivas, assim, pode representar tanto o interior quanto o exterior do corpo. E, ainda, segundo o autor, os reflexos internos da cavidade oral são os mais específicos e coerentes de todos, que desencadeiam o comportamento dirigido, assim, propôs que toda a percepção se inicia na cavidade oral, que 
funcionaria como ponte entre a recepção interna para a percepção externa. Ela seria o precursor da percepção (SPITZ, 1983).

A cavidade oral é responsável pelas experiências dos sentidos do tato, gosto, da temperatura, do odor e da sensibilidade profunda, pois está envolvida na deglutição. Além disso, essas percepções que ocorrem na cavidade oral seriam também percepções por contato.

Nota-se que, embora a percepção por contato e a percepção à distância sejam diferentes, elas muitas vezes incidem conjuntamente nas experiências do bebê, pois ao ser amamentado, por exemplo, o bebê visualiza o rosto da mãe e ao mesmo tempo sente o bico do seio em sua boca.

Spitz (1983) também ressalta que na experiência de amamentação o bebê vivencia variações nesse contato, pode deixar escapar e recuperar o mamilo algumas vezes enquanto suga o seio, nesse jogo, perde e recupera o contato com o percepto de satisfação de sua necessidade. Por outro lado, enquanto isso acontece, o bebê poderá manter o contato visual com a mãe, mantendo a percepção à distância contínua enquanto recupera a percepção por contato com o seio. Com isso, o autor demonstra que a troca de olhares por se manter em continuidade se torna a mais recompensadora entre as duas, apontando para as origens da constância objetal e da formação de objeto.

\footnotetext{
Assim, a experiência de amamentação, a situação de amamentação, não é simplesmente uma experiência de satisfação. Ela inicia a transição da percepção por contato exclusiva para a percepção à distância. Essa experiência ativa o sistema perceptual diacrítico, que gradualmente substitui a organização cenestésica original e primitiva (SPITZ 1983, p.80).
}

Desse modo, o autor mostra como as experiências do bebê irão contribuir para o processo de diferenciação e aquisição do princípio de realidade, tendo suas raízes no desenvolvimento e transição da organização perceptiva no bebê.

Segundo Freud "uma pré-condição essencial para o estabelecimento da função do teste de realidade é de que objetos perdidos tenham proporcionado anteriormente uma satisfação real" (FREUD, 1925 apud SPITZ, 1979, p.15).

Conforme coloca Spitz (1979) esse argumento de Freud pode ser pensado em relação à experiência de amamentação onde o bebê encontra o objeto de satisfação de necessidade e o perde inúmeras vezes. Nesse sentido, quando o bebê for capaz de reconhecer visualmente o 
rosto humano e reagir a ele com um sorriso, pode se pensar no início do estabelecimento do sentido de realidade. Voltaremos a esse ponto mais adiante...

Complementar nesse desenvolvimento do sistema perceptual do bebê, Spitz (1983) também discutiu a participação de outras regiões sensoriais, argumentando o caráter indissociável, embora não os trate com a centralidade que entende o papel da cavidade oral, mas, ainda assim, revela a importância de considerar e compreender o imbricamento sensorial no bebê.

A esse respeito discorre que há outros três órgãos auxiliares envolvidos na percepção rudimentar do bebê: a mão, o labirinto (sistema vestibular) e a pele. Em relação a mão, propõe que o contato da mão do bebê com o corpo da mãe, principalmente com o seio durante amamentação se torna cada vez mais organizado ao longo dos seis primeiros meses de vida.

Spitz (1983) sustenta que nessa atividade em que o bebê toca com a mão o corpo da mãe ou mesmo leva a mão à própria boca estariam envolvidas as bases da autopercepção, pois ele supõe que essa ação do bebê será percebida proprioceptivamente.

O mesmo ocorre em relação ao labirinto, pois observou que bebês recém-nascidos quando sofrem mudança de posição apresentam resposta de enraizamento e sucção. Com isso, a mudança de posição do bebê para amamentação produz sensações vestibulares que podem ser captadas pelo sistema proprioceptivo. O que também é válido para o contato com a superfície da pele do bebê.

Com isso, argumenta que os três órgãos auxiliares estariam subordinados ao "sistema central perceptual da cavidade oral" e, no recém-nascido, funcionariam em conjunto porque ainda se manteriam não-diferenciadas entre as várias modalidades sensoriais existentes. O que implica dizer que as "sensações por elas mediadas incorporam-se e combinam-se, de maneira a serem 'sentidas' pelo recém-nascido como uma experiência situacional unificada com o caráter de 'tomar', de incorporar” (SPITZ, 1983, p. 78).

Essa experiência unificada parece importante à medida que se relaciona com a satisfação da necessidade do bebê, proporcionando redução de tensão após o período de excitação e promovendo um período de quietude e prazer. Verifica-se ainda, segundo o autor, que essa é uma experiência iterativa, ou seja, uma experiência marcada por este conjunto de sensações que se repetem na mesma sequência em diferentes períodos do dia, diariamente ao longo dos primeiros meses de vida e para além do primeiro ano de vida. Dessa forma, essa experiência 
unificada e iterativa contribuiria para algum tipo de registro nesse começo, para "alguma forma de registro psíquico" no bebê (SPITZ, 1983, p.79).

O que vai se configurando é que as primeiras percepções do bebê têm suas origens como uma função da necessidade e da satisfação da necessidade, soma-se a isso o fato de que existem variações no atendimento dessas necessidades por parte da mãe ou de quem cuida. O autor sinaliza que a demora pode ser um fator desses e ocasionar frustração ao bebê o que estaria na origem do desenvolvimento adaptativo e seu elemento mais importante, a memória.

\section{O estágio precursor do objeto}

Verificou-se que, durante o estágio pré-objetal, o bebê vai organizando seu sistema sensorial de modo a perceber a si mesmo e o mundo. Embora, falamos em percepção no bebê, já dissemos que não é a percepção tal como se apresenta no adulto, mas esta funcionaria mais como um sistema receptor, um início onde o bebê faz pequenas apreensões de sensações advindas do interior do próprio corpo ou captadas por contato com o corpo materno ou ambiente.

Observamos que nesse começo os órgãos sensoriais envolvidos nesse processo de recepção/percepção são olhos, mãos, labirinto e a cavidade oral, funcionando de forma nãodiferenciada, unificada e iterativa.

Vimos, ainda, que o bebê pode fazer experiências de percepção por contato e por percepção à distância, variações que são importantes para o processo de desenvolvimento psíquico do bebê.

Ao retomar esses pontos, podemos dizer que por volta dos dois meses de vida o bebê terá no rosto humano um objeto privilegiado de percepção visual, pelo qual demonstrará seu interesse e sua preferência.

Nesse momento, o bebê será capaz de isolar e discriminar o rosto humano do ambiente, poderá investir sua atenção e dirigir-se à ele de modo inteiramente novo. Agora, o bebê é capaz de oferecer uma resposta quando percebe o rosto de outra pessoa: ele pode sorrir. 
A resposta de sorriso, segundo Spitz (1983), é a expressão de uma experiência psicológica do bebê, por ocasião do progresso maturacional físico e do desenvolvimento psicológico que, agora, pode ser coordenada e apresentada como resposta ao contato com a face humana. O sorriso, nesse sentido é a primeira manifestação comportamental, ativa, dirigida e intencional do bebê.

Em seus estudos, o autor verificou que embora a resposta de sorriso possa estar presente no bebê aos três meses de idade e, essa se dê em reconhecimento à face humana, esse comportamento ainda não indica o estabelecimento de uma relação objetal. Ela aponta para uma melhor organização da ação e passa mostrar uma intenção no bebê.

Spitz (1983) explica que a reação de sorriso dos três aos seis meses ainda não é oferecida a face humana completa, mas em resposta a alguns elementos do rosto humano, a certa gestalt que se apresenta no rosto humano e consiste na testa, olhos e nariz, acrescido do todo em movimento.

\begin{abstract}
O que o bebê reconhece neste sinal gestáltico não são as qualidades essenciais do objeto libidinal; nem os atributos que motivam o objeto a atender às suas necessidades, protegê-lo e satisfazê-lo. O que ele reconhece durante o estágio pré-objetal são atributos secundários, externos e não essenciais. Ele reconhece um sinal gestáltico, que é uma configuração na face humana - não em uma face individual específica, mas em qualquer face que lhe seja apresentada de frente e em movimento (SPITZ, 1983, p.93).
\end{abstract}

Compreende-se, então, que esse estágio é chamado de pré-objetal porque o bebê ainda não discrimina um rosto humano individual de outros, ainda não é capaz de distinguir e conceder ao rosto humano atributos objetais. Haverá um tempo até que o bebê possa transformar esse sinal em seu objeto de amor individual, ou seja, reconhecer a mãe ou cuidador como tal. Aqui, o "que a criança percebe não é um companheiro, não é uma pessoa, nem tão pouco um objeto, mas, apenas um sinal” (SPITZ, 1960, p.37).

O reconhecimento deste sinal gestáltico pelo bebê aos três meses de idade é indicativo da transição da percepção de "coisas"' para a constituição do objeto libidinal. E, o objeto libidinal se diferencia das "coisas" e do pré-objeto pela concessão de qualidades fundamentais

\footnotetext{
${ }^{6}$ Spitz (1983) parece chamar de coisas, objetos que não o objeto da libido, objetos concretos. Isso parece se confirmar quando comenta que a partir da percepção diacrítica e do estabelecimento do precursor do objeto o bebê atinge a discriminação, por exemplo, a mamadeira como uma "coisa" familiar (p.133).
} 
ao longo das trocas entre a mãe e o bebê, ocasião em que o objeto ou o que se tornará objeto é progressivamente investido com catexia libidinal (SPITZ, 1983).

Apresenta outros dados ao falar do sinal gestáltico, destacando que, talvez, os olhos sejam o elemento central dessa configuração, somando-se a esta a importância do movimento para auxiliar na percepção do bebê. Entretanto, nos previne de que a existência do sinal e da resposta não é suficiente, assim sendo, ressalta a importância do relacionamento com outro ser humano para que essas tendências inatas se desenvolvam no bebê.

Só uma relação recíproca é capaz disso. Só uma relação humana recíproca pode fornecer o fator experiencial do desenvolvimento do bebê, consistindo como acontece, de uma troca circular contínua, na qual os afetos desempenham o papel principal. Quando o bebê sente uma necessidade, esta provocará nele um afeto que conduzirá a mudanças comportamentais que, por sua vez, provocam uma resposta afetiva e atitude concomitante da mãe; ela se comporta "como se compreendesse" que necessidade particular do bebê causa sua manifestação afetiva (SPITZ, 1983, p.97).

Isso nos leva ao entendimento de que o bebê se constitui a partir de uma relação humana, é fundamental que haja desde o início um parceiro humano que possa mediar toda percepção, ação, discriminação e conhecimento para o bebê. Essa relação e a possibilidade de o bebê estabelecer contato visual e manter esse contato, apoiado em uma relação de troca afetiva permite ao bebê diferenciar essa parceria e conferir significado cada vez maior à ela.

O bebê passa a destacar a mãe ou cuidador dos demais aspectos ambientais sem significado para ele. $\mathrm{O}$ bebê transita de um estado onde percebe apenas emocionalmente para um estado diferenciado, pois passa a perceber de maneira discriminante, melhor dizendo, de forma diacrítica.

Essa relação recíproca indica que a parceria da mãe é fundamental para que essa diferenciação possa ser construída pelo bebê, uma vez que, diante da necessidade apresentada à mãe oferece uma resposta, ela oferece sua compreensão à necessidade do bebê. Com isso, além de satisfazer a necessidade que surge a mãe também oferece um sentido a necessidade, o que ajuda o bebê em seu desenvolvimento psíquico. A mãe "quem serve de interprete para toda a percepção, para toda ação e para todo o conhecimento" (SPITZ, 1960, p. 40).

Como inicialmente há no bebê um predomínio das percepções afetivas, pois a capacidade de percepção discriminativa ainda não está operante, a relação emocional com a 
mãe, sua disposição afetiva e seus afetos auxiliam a orientação dos afetos do bebê e atribuem "qualidade de vida à experiência do bebê" (SPITZ, 1983, p.99).

Acrescenta-se que a mãe não é a única pessoa no ambiente da criança, nem menos a única influência emocional. Este ambiente é composto por outras pessoas da família; pai, irmãos, tios, avós e outros que se encontrarem em relação com a criança. Inclui-se ainda o ambiente cultural do qual a família faz parte, estendendo das relações familiares para as relações sociais. A consideração desse ambiente é de fundamental importância, uma vez que, a transmissão do mesmo à criança será feito pela mãe ou substituto.

Assim, "a mãe representa os dados ambientais - ou poderia ser dito que a mãe é a representante do ambiente" (SPITZ, 1983, p.101).

A partir disso, teremos a mãe com sua individualidade e maturidade e o bebê em desenvolvimento, ambos em contínua relação. Esta relação, por sua vez, inaugura uma série experiências que servirão de base para a construção da relação objetal que proporcionará ao bebê amostras das futuras relações com o mundo.

O que temos, então, a partir desta díade é um bebê em desenvolvimento de diversas capacidades, pois partindo das experiências sensoriais, vai aos poucos, pela capacidade adaptativa e integrativa transformando as experiências em memórias. Estas últimas constituemse dos registros dessas primeiras discriminações diacríticas que o bebê realiza na relação com a mãe, enquanto ruma para construção de uma relação amorosa com ela. É o funcionamento inicial do ego, um ego rudimentar.

O que se vê a princípio são ações com direção e intenção, embora desajeitadas e nem sempre bem sucedidas, mas com o funcionamento do ego rudimentar, nota-se uma crescente coordenação e direção da atividade muscular do bebê (SPITZ, 1983).

Observa-se que neste funcionamento rudimentar de ego há uma "tendência integrativa" que parece operar de forma progressivamente crescente no desenvolvimento.

Nesse sentido, os protótipos de núcleos psíquicos do ego parecem ser encontrados em funções fisiológicas e no comportamento somático, o que indicaria que essa formação de ego rudimentar derivaria de uma transição contínua dos aspectos somáticos para os psicológicos.

Com a possibilidade de ações dirigidas e mais estruturadas no bebê podem ser observadas outras formas de interação entre o bebê e a mãe (ou pré-objeto) o que permite ao bebê experimentar e estabelecer os limites de suas capacidades atuais. E, com isso, o bebê vai 
alcançando maiores condições de transferir para ações dirigidas a pressão de seus impulsos agressivos e libidinais.

Ressalta-se que as ações dirigidas do bebê além de servirem como meio de descarga de energia libidinal e agressiva, também atuam como um recurso na construção do domínio e controle através da psique, promovendo o desenvolvimento. Acrescenta-se que, o impulso agressivo não está limitado a hostilidade, ele tem a importante função de ativar "todo movimento, toda atividade, grande e pequena e, afinal, a própria vida" (SPITZ, 1953 apud SPITZ, 1983, p.105).

Verificamos que essas experiências e ações, cada vez mais intencionais, também influenciam o desenvolvimento psíquico do bebê. A partir do momento que o bebê direciona seus impulsos instintuais em suas ações ele passa a obter prazer com essas mesmas ações, o que facilita a manutenção e repetição dessas ações na relação com o ambiente.

Nesse momento, quando a mãe ou substituto compartilha desse prazer experimentado pelo bebê, seu prazer aumenta, bem como a procura de comunicação também se intensifica. Assim, a cada sucesso alcançado nessa relação, mais o bebê se apropria do comportamento que teve êxito. Aliado a isso, está o fato da mãe facilitar as ações do bebê que são agradáveis a ela, indicando que as preferências da mãe também influenciarão o desenvolvimento do filho.

Com isso, podemos notar que nas "relações da mãe 'boa, normal' com o filho, não se deve esquecer que há um gradiente não apenas da mãe para o filho, mas há também um gradiente indo do filho para a mãe" (SPITZ, 1983, p.121).

Notamos que essa relação se constitui de mútua influência, a presença e as ações de um ou de outro no campo comum dessa relação provoca reações em ambos os parceiros, temos então uma circularidade. Dessa maneira, percebe-se que este relacionamento que se estabelece de forma circular, em certos aspectos, está isolado do ambiente geral, ou seja, mantém-se em uma relação afetiva forte formada pela díade.

É no interior dessa circularidade que nasce uma comunicação entre esses parceiros. O que vem a ser comunicação para Spitz?

De pronto, em uma nota de rodapé, ele nos responde que comunicação é 
percepção, os sentimentos ou as ações de uma ou de várias pessoas, seja a influência voluntária ou não (SPITZ, 1954 apud SPITZ, 1983, p.123).

Comunicação, nesse sentido, seria algo que ao ser percebido pelos parceiros em relação ocasiona influência nos mesmos. A primeira vista, tal tentativa parece mesmo muito imprecisa e vaga, mas seguindo os passos do autor tentaremos apontar o sentido...

Nosso autor recorre a Freud para dizer que a fim de descarregar os estímulos originados no interior do próprio corpo, o bebê revela um aumento de atividade motora. Isso consiste em descarregar a tensão que surge a partir de uma necessidade, no entanto, a atividade motora em si (chorar, gritar etc.) não promove a liberação da tensão, o que só pode ser conquistado pelo atendimento da necessidade.

Transpondo para relação do bebê com a mãe, verifica-se que a mãe identifica através das manifestações do bebê o aparecimento de uma necessidade e ao atendê-la ela sofreu a influência que proporcionou a satisfação da necessidade do bebê. Dito de outra forma, a mãe compreende a necessidade do bebê através de uma comunicação que difere da comunicação oral. Trata-se de "uma comunicação não-verbal, não dirigida, expressiva" (SPITZ, 1960, p.59).

Spitz (1983) explica que nesse processo de comunicação não-verbal a díade lança mão de elementos do sistema de percepção cenestésico criados pelo clima afetivo do relacionamento da mãe com o bebê. Diante desses signos cenestésicos o bebê responde de forma total e a mãe compreende essas respostas de totalidade do bebê.

Para o autor, durante a gestação e mesmo um período após o parto haveria uma mudança na capacidade da mulher reagir aos sinais cenestésicos, uma espécie de aumento para percepção desses sinais. Porém, ele não oferece mais elementos com os quais pensar e continua enfatizando a importância das trocas afetivas entre o bebê e a mãe.

Nesse sentido, menciona que os signos afetivos que surgem a partir da disposição afetiva da mãe parecem tornar-se um modo de comunicação com a criança, bem como, essas trocas entre a dupla apresentam uma continuidade, mesmo que a mãe deles não esteja consciente.

Ao se referir ao clima afetivo está apontando as forças que influenciam o desenvolvimento do bebê, se refere ao efeito que os afetos da mãe podem produzir no psiquismo do bebê. Isso é corroborado quando diz que as funções psíquicas "baseiam-se em mudanças de catexia libidinal, que são percebidas pelo indivíduo e pelo ambiente como afetos e processos afetivos" (SPITZ, 1983, p.132). 
Assim, mesmo que disso não se deem conta, tanto a mãe como o bebê percebem o afeto presente e respondem em uma troca constante e recíproca, como já dissemos, em forma circular.

Mantendo a linha dos afetos, como já mencionado anteriormente, para Spitz (1983) os afetos iniciais no bebê são prazer e desprazer. Também já foi dito, que os afetos têm importante papel na relação da díade e, experiências investidas afetivamente respondem pelo registro das primeiras marcas de memória.

Sobre isso, é possível destacar a reação de sorriso como uma amostra da satisfação de necessidade esperada que se encontra vinculada com alívio da tensão. Outro indicador pode ser visto na reação de choro quando o bebê vê a mãe se afastar dele, indicando um aumento na tensão, gerando frustração no bebê. A alternância nessas condições de prazer e desprazer ou satisfação e frustração constituem o primórdio do desenvolvimento psíquico do bebê.

O autor destaca a importância da frustação para o desenvolvimento psíquico do bebê apontando que a mesma atuaria como um elemento de evolução, uma vez que, a partir da situação de desconforto, de desprazer, o movimento de busca de algo que altere essas condições se coloca em pauta, ou seja, favorece a mudança. "Em contato com estas frustações que se repetem, a criança atinge, no decorrer dos primeiros seis meses, um crescente grau de independência e torna-se cada vez mais ativa em suas relações com o mundo exterior, animado ou inanimado" (SPITZ, 1983, p.139).

Como se vê, a frustração desempenha um papel importante no interior da relação circular com a mãe, pois parece ser ela a responsável pela diminuição da dependência da criança em relação à mãe, ao mesmo tempo em que a criança passa a buscar o que precisa, cada vez mais, ativamente, ampliando também suas relações com o mundo.

\section{O estágio do objeto libidinal}

Pode-se observar que durante os meses iniciais de vida as capacidades de um bebê são crescentes, no período que compreende o sexto e o oitavo meses, muitas mudanças podem ser vistas como parte das conquistas efetuadas pelo desenvolvimento físico e psíquico do bebê. 
Uma destas conquistas é que o bebê já adquiriu a capacidade de diferenciar pessoas conhecidas e não conhecidas, pois sua percepção diacrítica está desenvolvida. Isto permite ao bebê realizar a distinção entre uma pessoa conhecida e uma pessoa estranha. Além disso, a criança começa a apresentar em intensidades variáveis tensão ou ansiedade, rejeitando a pessoa estranha.

Podemos, facilmente, notar esse comportamento quando crianças em período de idade aproximado entre os seis e oito meses parecem mostrar-se tímidas diante de estranhos, baixando os olhos ou cobrindo-os com as mãos, escondendo o rosto e até mesmo chorando ou gritando.

Spitz (1983) chamou essa expressão de estranhamento de ansiedade dos oito meses. Segundo ele, a ansiedade nos bebês se desenvolve em três passos ou poderia ser identificada em três momentos nos meses iniciais de vida.

O primeiro desses momentos seria logo após o parto, período em que é possível notar manifestações de desprazer em situações que em idade superior poderiam gerar ansiedade. Nesse período inicial, não podem ser chamadas de ansiedade, mas tem características de estados de tensão fisiológica com descarga física difusa e que ainda não possuem caráter psicológico.

Transcorrido um pequeno período de tempo a tensão vai perdendo seu aspecto difuso e passa a operar em momentos de desprazer, ganhando maior especificidade. Com isso, a excitação que se manifestava de maneira generalizada vai cedendo espaço para expressões de desprazer em sinais mais inteligíveis. Esse momento pode ser compreendido como o início da relação de comunicação entre o bebê e a mãe.

Vê-se, então, à medida que a expressão de desconforto ou desprazer na criança torna-se mais específica, a adaptação do ambiente as necessidades da criança, também progride. Essa comunicação facilita o estabelecimento de uma conexão para a criança entre o que ela faz e o que fazem por ela em resposta as expressões de necessidades.

Conjuntamente com essa adaptação às necessidades expressa de forma ativa pelo bebê, começa a se formar a temporalidade, pois a necessidade que se apresenta e o atendimento da necessidade acontecem em uma sequência temporal. Essa mesma sequência temporal se repete com regularidade diversas vezes na vida do bebê, graças a essa regularidade, há o estabelecimento dessa conexão entre a experiência de necessidade e satisfação dessa necessidade. As associações dessas duas impressões irão se constituir em memórias no bebê.

Os traços de memória, portanto, estão associados aos afetos de prazer e desprazer. Assim, a regularidade das experiências compõe os traços de memórias do bebê, 
particularmente, os traços de experiências desagradáveis quando reativados provocam na criança o afeto de desprazer. E este afeto apresenta-se como comportamento de afastamento ou medo, presente entre o quarto e o sexto mês de vida. Esse é o segundo passo em direção ao estabelecimento da ansiedade.

Sendo assim, o medo caracteriza-se pela percepção por parte do bebê de um objeto ou experiência que se associa a uma experiência de desprazer, como vacinação, por exemplo.

A ansiedade dos oito meses é diferente da reação de medo no bebê. A ansiedade dos oito meses aparece mediante "alguma coisa ou alguma pessoa com quem a criança nunca teve antes uma experiência de desprazer" (SPITZ, 1983, p.145).

Essa ansiedade específica aparece em situações de afastamento do bebê de sua mãe. Spitz (1983) notou que bebês entre três e seis meses reagiam com desprazer em situações onde o adulto cuidador se afastava. Considerando que um bebê aos oito meses já discrimina uma pessoa conhecida de estranhos, pode-se verificar que a ansiedade dos oito meses aparece em situações onde há a separação do bebê de sua mãe e o confronto com uma pessoa estranha.

Assim, "quando confrontada a um estranho, sua reação é a de que não se trata de sua mãe; sua mãe 'deixou-a" (SPITZ, 1983, p.145). Não se trata de uma lembrança de experiência desagradável com uma pessoa desconhecida, mas sim, uma resposta a alguém estranho, alguém que não se trata da mãe. Assim, a pessoa reconhecida como estranha será rejeitada.

Achamos que esta capacidade de deslocamento de catexia em traços de memória certamente guardados na criança de oito meses de idade reflete o fato de que ela estabeleceu, neste momento, uma verdadeira relação objetal, e de que a mãe se tornou seu objeto libidinal, seu objeto de amor (SPITZ, 1983, p.146).

Observa-se a capacidade que a criança conquista de distinguir sua mãe de outras pessoas, inclusive de pessoas estranhas, indica que a criança estabeleceu uma relação diferenciada com a mãe, ou seja, a mãe passa a ser a pessoa a quem a criança conferiu um lugar único, a quem está ligada, a pessoa que ela quer por perto e a quem ela dirige todos os investimentos afetivos para satisfazer suas necessidades, portanto, seu objeto de amor.

A ansiedade dos oitos meses, como segundo organizador da psique, indica o estabelecimento do objeto libidinal, tendo em vista que, somente a partir desse ponto, a pessoa dotada com atributos objetais "não pode ser intercambiada com nenhum outro indivíduo" (SPITZ, 1983, p.150). 
Esse é o ponto do desenvolvimento em que o bebê já de posse da capacidade de discriminar o objeto libidinal de outros, apresenta um melhor domínio do próprio corpo e uma capacidade crescente de memorizar. Nota-se que o bebê pode realizar cada vez mais ações dirigidas, além disso, pode através delas descarregar tensão psíquica, bem como, buscar satisfazer suas necessidades de forma cada vez mais eficiente.

Avanços importantes como esses no desenvolvimento do bebê são vistos como indicadores de integração do ego. Percebe-se maior desenvolvimento do ego do bebê para a conquista da relação objetal, assim como, a partir dela um enriquecimento do ego também se fará notar.

A integração do ego pode ser verificada no estabelecimento de contornos entre o ego e os impulsos instintivos, por um lado, e entre o ego e o sentido de realidade, por outro. Um enriquecimento do ego é alcançado à medida que novos mecanismos do ego se transformam em unidades em funcionamento. Isso é possível devido às trocas afetivas entre o bebê e o objeto libidinal recém-conquistado.

Nota-se que os mecanismos de defesa inicialmente servem mais como recursos para adaptação do bebê, do que propriamente como defesas. E entre os mecanismos que passam a operar no ego do bebê, um deles é especialmente importante no primeiro ano de vida: a identificação. Mais adiante, mostraremos o papel da identificação no desenvolvimento do bebê.

Agora, fundamental é ressaltar que o estabelecimento do objeto, indicado pelo surgimento da ansiedade dos oito meses é o ponto central do processo de diferenciação e integração do ego.

Importante dizer que uma diferenciação progressiva entre agressão e libido e o reconhecimento das vicissitudes de cada um desses impulsos instintivos participam desse processo de integração e organização do ego. Eles estão diretamente envolvidos no estabelecimento do objeto libidinal. Vejamos como isso acontece.

Logo ao nascer e no período narcisista que se segue ao nascimento do bebê os impulsos instintivos não se encontram diferenciados uns dos outros. Essa diferenciação entre os impulsos libidinais e os impulsos agressivos ocorrem como resultado da relação entre a mãe e o bebê, no período aproximado dos três primeiros meses de vida.

Significa pensar que durante o narcisismo as trocas entre o bebê e a mãe configuram experiências distintas, pois cada impulso é vivenciado de forma específica, separadamente. 
Nesse momento, os instintos libidinal e agressivo não se fundem e não se ligam, enquanto percorrem o período para o estabelecimento do pré-objeto.

Spitz (1983) destaca que durante o período do narcisismo, bem como no período de transição para o estabelecimento da relação de objeto, os impulsos instintivos buscariam a satisfação das necessidades orais do bebê. Apoiado na teoria freudiana, o autor ressalta que a mãe é a pessoa que satisfaz essas necessidades, sendo ela o alvo tanto dos impulsos agressivos quanto libidinais do bebê. No entanto, nesse momento, ela não é percebida como uma pessoa unificada, com consistência e permanência, ou seja, como o objeto libidinal.

Um acréscimo se faz necessário neste ponto, Spitz (1960) considera que as ações do bebê direcionam impulsos libidinais e agressivos e são parte inerente ao desenvolvimento. E complementa dizendo que "falamos frequentemente de agressão, entretanto é mister compreender que a parte da agressão que se manifesta sob a forma de ação, cria em si mesma, constelações de ação que estabelecem sistemas diversificados no Eu” (SPITZ, 1960, p.45).

O que parece querer comunicar é a importância dos impulsos agressivos que canalizados na atividade do bebê agem na constituição do Eu, na integração do ego em desenvolvimento. Feita essa pontuação, seguimos...

Como nesse ponto do desenvolvimento já existe um ego rudimentar em curso, o bebê experimenta a relação com a mãe em termos de satisfação ou não satisfação das necessidades. Assim, nos momentos da relação onde ele experimenta satisfação de suas necessidades o bebê direciona os impulsos instintivos libidinais e os impulsos agressivos seriam direcionados para os momentos de relação em que não há satisfação das necessidades.

Spitz (1983) refere que por volta dos seis meses o bebê seria capaz de realizar uma síntese dessas experiências, pois seu funcionamento egóico já é capaz de integrar as memórias dessas experiências regulares na relação com a mãe ao longo do tempo. Isso leva a compreensão de que para o bebê a mãe se torna uma pessoa única, que reúne em si as duas possibilidades de relação (satisfatórias e não satisfatórias), transformando-a em objeto de amor.

Nas palavras do autor, "chega-se a um ponto no qual a mãe, como unidade, como um "todo", deixa de ser percebida apenas como um elemento da situação específica na qual ela é vivenciada" (SPITZ, 1983, p.156).

A mãe tornada única nesse processo de síntese do bebê passa a receber o direcionamento dos impulsos agressivos e libidinais do bebê. O que se vê nesse mesmo processo é a fusão dos 
impulsos instintuais e a fusão das experiências de satisfação e não satisfação com a mãe concentradas agora em um só objeto: o objeto libidinal.

Nesse sentido, os aspectos da relação satisfatória com a mãe prevalecem sobre os aspectos de não satisfação, assim como, os impulsos libidinais do bebê prevalecem sobre o impulso agressivo, uma vez que o impulso libidinal é proporcional à necessidade do bebê. Dessa forma, os aspectos satisfatórios da relação ou os aspectos bons da mãe prevalecem nesta fusão, por esta razão o objeto libidinal também pode ser chamado de objeto de amor.

Ainda podemos pensar que a partir da fusão dos impulsos instintivos e da prevalência das experiências boas ou satisfatórias sobre as experiências insatisfatórias promove no bebê um processo de compensação, esse mesmo processo confere a ele a capacidade de suportar frustrações. Essa capacidade está na origem do sentido de realidade.

Suportar frustração refere-se a capacidade crescente que o bebê adquire de adiar a satisfação de suas necessidades de maneira imediata, ele adquire capacidade de adiar, de esperar. Isto é possibilitado pela compensação pelo objeto que é sentido como bom ou satisfatório dos aspectos insatisfatórios, isto proporciona o aparecimento do sentido de realidade, não apenas tornando-o suportável, mas, também, recompensador.

Isto posto, teremos os dois impulsos direcionados para um objeto unificado e mais fortemente investido do ponto de vista emocional, o que confere a possibilidade de falar do estabelecimento do objeto libidinal e o início das relações objetais, base para o estabelecimento das relações com o mundo.

Com o estabelecimento das relações objetais (segundo organizador) o desenvolvimento do bebê adquire novos e enriquecidos avanços. Observa-se que se iniciam novas formas de relações sociais e o bebê começa mostrar sinais de compreensão de gestos sociais e de seu uso como forma de comunicação.

É possível notar que o bebê passa a compreender e responder em situações onde há proibições e ordens. Além disso, modificações importantes acontecem na esfera das relações da criança com os objetos e o espaço. Observa-se que a criança adquire a capacidade de discriminar objetos inanimados e, esta conquista está relacionada as trocas que são realizadas com o objeto de amor, a mãe.

Essa relação se apresenta como facilitadora desse desenvolvimento, pois a criança primeiramente discrimina a mãe de pessoas estranhas e, pouco depois, ela passa a discriminar 
um objeto de outro, nesse momento, já é possível notar a preferência da criança por alguns objetos ou brinquedos.

Anteriormente, falamos da importância da identificação no desenvolvimento psíquico do bebê, muito bem, é nesse momento do desenvolvimento que ela pode mais facilmente ser notada.

Ressalta-se que a identificação está relacionada com o desenvolvimento do comportamento de imitação no bebê. E, entre o oitavo e décimo mês de vida é possível observar crianças imitando gestos de adultos, embora, este comportamento também possa estar presente muito mais cedo em alguns bebês. Desta forma, "a identificação através do gesto é somente um precursor do mecanismo da própria identificação" (SPITZ, 1983, p.165).

Essas identificações surgem ao longo das relações de objeto, especialmente em situações de jogos e brincadeiras entre o adulto e a criança, como uma ação que espelha o gesto realizado pelo adulto. Mais adiante, a criança toma a iniciativa e a imitação dos gestos do objeto de amor aparece em brincadeiras espontâneas entre ela e os pais ou mesmo sozinha (SPITZ, 1978).

A relação com a mãe e o ambiente emocional que ela proporciona ao bebê são importantes para o surgimento da imitação. A relação da díade promove as tentativas do bebê de agir e ser como a mãe. Nesse sentido, ser e fazer como a mãe torna a criança capaz de propiciar a si mesma aquilo que a mãe lhe proporcionou. Assim, ser capaz de agir, dominar a imitação e identificar-se com a mãe são aquisições que permitem a criança maior autonomia em relação à mãe.

As mudanças na relação do bebê com o espaço se alteram bastante, especialmente quando ele adquire capacidade de se locomover, pois a partir daí pode se distanciar da mãe, mostrando maior independência na relação com ela. Isso também indica outras mudanças, antes a relação do bebê com a mãe era pautada na proximidade física, principalmente no contato corporal, com a locomoção outras formas de relacionamento também serão desenvolvidas.

A aquisição da capacidade de locomoção pela criança revela os avanços e sinaliza alguns perigos, pois agora ela pode explorar o espaço e arriscar-se em situações que podem feri-la, por exemplo. Isso passa a gerar intervenções cada vez mais frequentes da mãe para evitar acidentes com a criança, entretanto, com a distância que a criança pode tomar da mãe, o uso dos gestos e das palavras adquirem maior força e frequência. 
Não implica dizer que anteriormente não houvesse comunicação verbal e uso de palavras na relação da dupla, isso acontece, muitas vezes criando uma comunicação entre a mãe e o bebê, que responde a fala da mãe balbuciando ou com excitação, por exemplo (SPITZ, 1983).

Significa pensar que impedimentos e proibições entram em cena na relação da mãe com o bebê, tendo em vista que a condição ativa do bebê produz essa mudança na mãe.

Desde que a locomoção é adquirida tudo isto muda. O cantarolar é substituído pela proibição, pelas ordens, pela reprovação, pela invectiva. A palavra que ela usa com mais frequência é "Não! Não!", e dizendo essas palavras ela balança a cabeça, enquanto impede a criança de fazer o que estava pretendendo (SPITZ, 1983, p.169).

Então, a palavra e o gesto usados para a proibição são enfatizados pela mãe na realização de uma ação junto à criança, essa relação contínua possibilita ao bebê entender as interdições verbais. $\mathrm{O}$ bebê vai assimilando as proibições por meio do processo de identificação.

Aqui, não se trata mais da identificação primária do período de indiferenciação e, sim, de um momento onde os limites entre o "Eu" e o "Não-eu” já se estabeleceram e a identificação que acontece é de maior complexidade (SPITZ, 1978).

Com o tempo o que vemos é a imitação pelo bebê do meneio negativo de cabeça da mãe e a repetição da palavra "Não", ou seja, o bebê imita o gesto da mãe, ele faz como a mãe. O que aos poucos, será transformado em símbolo e marca permanente de uma ação frustradora da mãe. Estes serão representações de um conceito: negar, recusar.

Entretanto, Spitz (1978) nos aponta que não apenas o bebê imita o gesto do adulto, mas os pais, também imitam as palavras ou gestos realizados pelo bebê, o que implica em um processo de identificação muito primitivo, uma vez que, os pais regridem temporariamente as necessidades da criança.

De fato, esses processos identificatórios dos pais fazem parte e são parcela das relações de objeto. Sem eles, o desenvolvimento da criança em um ser humano estaria prejudicado. Penso que podemos dizer, sem exagero, que estas identificações dos pais, em um nível arcaico, foram uma ponte com a ajuda da qual a criança, revertendo o processo, se torna capaz de identificar-se com os pais (SPITZ, 1978, p. 60). 
Observamos, porém, que a imitação da criança adquire um sentido que vai além da repetição de um gesto, ela emprega este gesto e, posteriormente, a palavra em algumas situações de recusa, seja por solicitação ou oferecimento de algo para ela.

Para estabelecer uma compreensão da assimilação do conceito "Não" pelo bebê, Spitz $(1978,1983)$ discorre sobre duas proposições, uma extraída dos experimentos da Gestalt e outra da teoria psicanalítica.

A primeira: Para a criança, a cada proibição, seja verbal ou gestual, ou a combinação de ambas, a ação pretendida fica impedida. A implicação seria a de que quanto mais proibições a criança experimenta, mais tarefas incompletas ou inacabadas ela deixa para trás. Diante disso, a criança acumula lembranças do fator comum - o Não - mas, não lembranças das atividades ou ações que ela foi impedida de realizar ou fazer.

A segunda: Considera que a cada proibição experimentada pela criança uma frustração está em curso. Implica dizer que, diante das proibições das ações, interdições nas satisfações das necessidades ou discordâncias nas formas de relações objetais, há frustração da instintualidade do bebê. O que marcaria os traços de memória com investimentos específicos, como: sentimento de recusa, de derrota, fracasso, ou melhor, frustração.

$\mathrm{O}$ autor indica ainda que as atividades do bebê interditadas pela proibição colocariam o bebê na posição de passividade, o que se conformaria mais com a posição narcísica. No entanto, no momento em que as proibições começam a existir o bebê já está saindo do narcisismo e passando para as relações de objeto, portanto, a criança oferecerá resistência a retornar ao estado de passividade. O bebê tentará transpor os entraves para continuar em posição ativa (SPITZ, 1978).

Soma-se a isso que a carga afetiva ocasionada na experiência de frustração gera um investimento do impulso instintivo agressivo no traço de memória do bebê. Esse movimento psíquico é importante para o estabelecimento da identificação como um mecanismo de defesa na tentativa de domínio da situação pelo bebê.

De acordo com Spitz (1978), “o 'Não' (gesto e palavra) é o elo de identificação com o objeto libidinal" (p.66). Como ele foi investido pelo impulso instintivo agressivo em diversas situações desagradáveis ele se transforma em um meio de expressar agressividade. É utilizado como modo de expressar agressão pela identificação como mecanismo de defesa com o frustrador. O bebê na relação com a mãe que proíbe pode tomá-la como objeto frustrador e direcionar o "Não" para a mesma. 
Isso seria possível, na medida em que, existe por parte do bebê uma necessidade de identificação com o objeto de amor.

A necessidade de identificação é tão forte, tem um papel tão grande nas relações de objeto, que a criança se identifica indiscriminadamente com qualquer comportamento do objeto amado que for capaz de apreender. É como se a identificação passasse por uma fase de não diferenciação. A criança o concebe em favor da identificação, e o usa para as relações de objeto e de domínio, para a defesa e ataque (SPITZ, 1978, p.67).

Sendo assim, o bebê de modo indiscriminado assimila coisas, gestos, ações etc., enfim, o que estiver disponível na relação com o objeto de amor, inclusive se identificará com o desprazer, o que talvez ajude a explicar a identificação com o frustrador (agressor).

As proibições que a mãe direciona para as ações do bebê poderiam ser vistas sobre três ângulos: o gesto ou palavra, o pensamento e o afeto que acompanham as ações da mãe. Desses três aspectos, o bebê é capaz de incorporar integralmente apenas o gesto (SPITZ, 1978 e 1983).

Outro fator a ser considerado é que um bebê por volta dos quinze meses é capaz de compreender a proibição, mas ainda não é capaz de compreender os motivos e os sentidos particulares que levam os pais a proibirem algumas ações. Assim como, a criança ainda não está suficientemente desenvolvida para distinguir os tipos de afetos envolvidos na relação com o objeto de amor.

Isso levou Spitz (1978) a dizer que crianças, nessa idade, seriam capazes de discriminar apenas dois tipos de afeto, que denominou de "a favor" e "contra". O que parece indicar que a criança sente que o objeto de amor a ama ou a odeia.

Percebe-se que a aquisição do gesto de negação acontece por meio da identificação com o adulto que cuida, porém a abstração do significado da negação é um processo de síntese do ego. Por meio dele, os elementos essenciais e não-essenciais dados nas bases afetivas da relação são separados da experiência com ajuda do impulso agressivo.

A frustração afetiva de parte do objeto de amor é sempre mais essencial do que o objetivo subordinado [...]. A qualidade essencial da frustração afetiva de parte do objeto de amor isola, entre todas as outras possibilidades de abstração, o "Não" e faz dele o primeiro conceito abstrato do processo mental (SPITZ, 1978, p.76). 
Quer dizer que a criança, por seus processos inconscientes, atribui significado semântico ao "Não" e, a partir do objeto de amor o assume para si, então, agora pode usar o gesto "Não" contra o próprio objeto.

De posse disso, vemos, então, que é partir da incorporação do gesto de negação que há uma substituição, pela criança, do emprego anterior de uma ação para uma mensagem, o que inaugura a comunicação à distância. Com isso, a troca de mensagens entre o bebê e a mãe se torna possível, ganha intenção e direção. E logo, com os símbolos semânticos teremos a origem da comunicação verbal. Portanto, a conquista do sinal de negação e da palavra "Não" é o indicador da formação do terceiro organizador da psique (SPITZ, 1983).

Resumindo nosso percurso, podemos dizer que o desenvolvimento do bebê no primeiro ano de vida, nessa perspectiva, compreende mudanças importantes de um período de maior passividade para atividade no bebê. Essas alterações no curso do desenvolvimento podem ser vistas no avanço de uma condição de desemparo e dependência absoluta para uma crescente independência do bebê em relação ao ambiente.

Vimos que a expressão de sorriso no bebê se configura como primeiro organizador da psique, o primeiro indicador de maior atividade e comportamento relacional do bebê ativo na presença de outras pessoas, especialmente, em reação ao rosto humano.

Com o estabelecimento do primeiro organizador, os avanços na atividade e desenvolvimento do bebê se torna visivelmente mais rápido, o que pudemos ver no desenvolvimento somático ou corporal do bebê e nas mudanças no modo de percepção e relação com o objeto.

Agora, com o surgimento da ansiedade dos oito meses, o segundo organizador da psique, observa-se o início da organização e integração do ego, com a presença de um aumento significativo da atividade corporal. Com o aumento dessas atividades nos setores físico e mental, a ansiedade dos oito meses pode ser considerada como precursora da aquisição da negação, tendo em vista, que é a expressão de uma recusa a aproximação de uma pessoa estranha, uma primeira forma de negação.

Embora, a ansiedade de oito meses não possa ser elevada ao status do gesto de negação e dele se diferencie, pois a primeira expressa seu desprazer diante de um estranho, indicando a separação ou afastamento do objeto de amor. Já, o segundo, ao expressar o meneio de cabeça "Não" a criança já mostra sua identificação com o objeto de amor e, consequentemente, com a proibição que lhe é imposta por ele. 
Não faz parte de nossos objetivos discorrer sobre os problemas ou distúrbios no desenvolvimento, entretanto, como Spitz (1979) nos aponta o estabelecimento frágil ou não estabelecimentos dos organizadores psíquicos no curso do desenvolvimento do bebê pode apontar para entraves ou estabelecimentos patológicos na primeira infância. 


\section{$1.4 \mathrm{O}$ desenvolvimento do bebê no primeiro ano de vida na perspectiva de Winnicott}

Nesse capítulo, apresentaremos o desenvolvimento do bebê, abordando-o a partir da relação materna como fonte dos cuidados necessários que possibilitam a existência do bebê como pessoa. Para tanto, tentaremos mostrar a mãe e suas disposições psíquicas para a identificação com o bebê, os cuidados como holding e handling e os cuidados da mãe como ambiente, através do qual, esses aspectos do relacionamento materno se integram e constituem a relação da mãe com o bebê.

Em seguida, mostraremos quem é o bebê na visão do autor, quais são suas necessidades, as tarefas que constituem o desenvolvimento e constituição do Eu e da subjetividade do bebê, mostrando as dimensões que compõem essa subjetividade.

Trilhamos este caminho, como forma apresentar quem é o bebê nessa perspectiva e como se dá seu desenvolvimento, no entanto, como este último é sempre em relação com o ambiente, veremos que em nosso texto, a relação está sempre presente.

Ao final, faremos algumas considerações sobre o brincar como constitutivo do amadurecimento do bebê e da saúde.

\subsubsection{Linhas gerais do pensamento de Winnicott}

Em seus estudos sobre desenvolvimento, Winnicott se interessou em mostrar e caracterizar os processos de constituição psíquica, enfocando as descrições dos aspectos que apontavam para fatos cotidianos comuns, buscando principalmente a compreensão desses em termos de saúde. 
positivo, fazendo com que a ausência de doenças não seja mais que o ponto de partida para uma vida saudável (WINNICOTT, 1990, p.21).

Para o autor, a questão da saúde está relacionada com a questão do viver, com o sentido de estar vivo, o que em seu entendimento não se limita apenas a um funcionamento físico e fisiológico saudável, mas engloba as questões psicológicas que precisam ser igualmente consideradas, compreendidas e cuidadas.

Com a experiência clínica acumulada como pediatra e psiquiatra de orientação psicanalítica, observou, principalmente, os relacionamentos entre as mães e seus bebês, enfatizando a importância dos cuidados maternos para o desenvolvimento físico e emocional do bebê.

O autor se dedicou a descrever os aspectos que compõe o desenvolvimento psíquico saudável, se preocupando em demonstrar mais o caráter flexível na organização das defesas do que o caráter fixo e rígido das patologias (WINNICOTT, 1994, 2006).

Winnicott se interessava pelas mães comuns, como ele gostava de dizer: "as mães dedicadas comuns". Isto porque, seu olhar e escuta se voltavam para as atividades e tarefas diárias às quais as mães realizavam, enquanto estavam envolvidas com seus bebês. O que chamava a atenção dele, fundamentalmente, era o que as mães faziam bem, o modo como elas cuidavam de seus bebês, a maneira de ser e estar com seus filhos durante os cuidados necessários.

Ele procurava fazer com que as mães "descrevessem o modo de vida de seus bebês nos estágios iniciais, antes que a mãe perdesse contato com essas intimidades" (WINNICOTT, 1983, p.212). Além disso, seu trabalho de análise pessoal e o trabalho com pacientes bordeline o levaram a pensar sobre a condição humana mais precoce, ou seja, a vida inicial das pessoas.

Assim, o autor vai construindo uma teoria de desenvolvimento psíquico, que nomeou de teoria do amadurecimento, enfatizando principalmente os aspectos relativos à situação de dependência que o bebê está sujeito no início da vida.

Nas palavras do autor "é importante reconhecer o fato da dependência. A dependência é real. É tão óbvio que os bebês e as crianças não conseguem se virar por si próprios, que as simples ocorrências de dependências passam facilmente despercebidas" (WINNICOTT, 2006, p.73). 
Winnicott seguirá dizendo que no início de suas vidas, o fato dos bebês serem dependentes de forma quase absoluta os colocam em uma posição onde são necessariamente afetados por tudo o que acontece.

É fato que um bebê precisa de alguém que dispense cuidados em um momento tão delicado e frágil de sua vida, que possa reunir o bebê e protegê-lo em seu desamparo, "decorre então que a maneira pela qual o meio ambiente se apresenta tem importância, por ser uma parte do bebê" (WINNICOTT, 1994, p.196).

Posta a situação de dependência do bebê, passa-se a compreender a importância de outro de quem o bebê possa depender. Assim, fundamentalmente, a pessoa que cuida precisa apresentar condições de identificar-se com as necessidades do bebê neste estágio de dependência, proporcionando os cuidados necessários ao momento de vida em que o bebê se encontra.

Winnicott entende que esse lugar, preferencialmente, deve ser ocupado pela mãe ou por um substituto da mãe e que, independente de quem assuma a posição de cuidados, as necessidades do bebê precisam ser acolhidas e atendidas de forma a garantir o desenvolvimento do bebê e sua saúde.

O ambiente da criança, na perspectiva de Winnicott, é composto pela mãe, o pai e as relações de cuidados que o bebê recebe nesse contato. Entretanto, como os cuidados do bebê inicialmente são realizados pela mãe, ela é o ambiente, que preferencialmente, deveria estar apoiada pelo pai ou familiares nesta tarefa.

Já é possível notar que o âmbito de relações de um bebê no início de sua vida fica circunscrito à mãe ou ao substituto materno. Também se percebe que essa relação possui algumas especificidades, ou seja, esta relação acontece de um determinado modo. Falar em um determinado modo parece impreciso e pouco definido, mas é assim que parece possível apresentar no momento, pois a relação da mãe com o bebê acontece ou não, considerando algumas disposições na mulher que se tornará mãe. Mas, então, o que acontece?

O apoio, do qual falamos, deveria estar presente desde a gestação, pois a mulher nesse período experimenta algumas alterações em seu psiquismo.

Estas alterações ocorrem com um retraimento ou um tipo de concentração e parece ser observado em mulheres que vão se aproximando do final da gestação e se estenderia por semanas ou meses após o nascimento do bebê, mas, gradativamente cessa e dá lugar ao modo 
normal de relacionamento. Isto é o que o autor chamou de preocupação materna primária (WINNICOTT, 2006).

A preocupação materna primária seria, então, um facilitador do estabelecimento da relação da mãe com seu bebê, um modo de se relacionar que permite a mulher se identificar com o bebê em situação de dependência.

É provável que, nestas circunstâncias, as mães se tornem capazes, de uma forma especializada, de se colocar na situação do bebê - quero dizer, de quase se perderem em uma identificação com ele, de tal forma que saibam (genérica ou especificamente) aquilo que o bebê precisa naquele exato momento (WINNICOTT, 2006, p 83).

Essa fase de preocupação materna primária é marcada por uma mudança de centro, ou seria melhor dizer, por um descentramento? Sim, porque a mulher candidata a mãe que abre espaço para uma identificação com o bebê, deixa momentaneamente de pensar em si mesma, de cuidar de si mesma para cuidar de seu bebê. Ora, duvide disso, quem nunca viu uma mãe com seu filho recém-nascido... É fácil encontrá-la ao final do dia vestida em camisola e com cabelos despenteados, não é?

Parece visível a dedicação e a preocupação que algumas mães desenvolvem pelo bebê, identificando o que ele precisa em cada momento e, ao longo do tempo - e que nem é tão longo assim - a mãe já sabe o que o bebê necessita, já reconhece e diferencia cada tipo de choro e gesto. A mãe sabe de cada necessidade básica de seu bebê e de um modo que só ela sabe, sem saber como sabe!

É importante compreender o estado de preparação que a futura mamãe passa durante a gestação, para que possa envolver-se e identificar-se com seu bebê. Essa identificação é importante como facilitadora de uma relação de adaptação ao bebê, uma vez que, "só um ser humano pode conhecer um bebê de forma a possibilitar uma complexidade de adaptação cada vez maior, e graduada de acordo com as transformações das necessidades dos bebês" (WINNICOTT, 2006, p. 32).

Com isso, o autor nos indica que essa capacidade de adaptação às necessidades do bebê pode ser desenvolvida, apontando para a possibilidade de que outras pessoas, além da mãe possam assumir a posição de cuidados com o bebê.

A adaptação será uma ação fundamental para a formação da relação de cuidados com o bebê e esta relação de cuidados também se altera no curso de amadurecimento do bebê. Quer 
dizer que, à medida que o bebê vai formando a relação com a mãe (e/ou substituto), ou seja, inaugurando a relação objetal, a capacidade do bebê em diferenciar-se da mãe cresce, assim como, é crescente também o estabelecimento da relação com a realidade, o que permite a mãe poder alterar sua forma de relação com o bebê.

Apoiados nisso, é possível dizer que a mãe se adapta as necessidades do bebê. Ela desenvolve uma adaptação ativa as necessidades dele. É pela adaptação da mãe que o bebê se desenvolve, em especial, no começo da vida, em que apenas o que há de mais simples pode ser vivido pelo bebê.

Embora a adaptação da mãe às necessidades do bebê seja fundamental, especialmente nos momentos iniciais, destaca-se que ela jamais se dará por completo. Há uma lacuna entre a adaptação total e a adaptação incompleta. Essa lacuna será elaborada pela crescente capacidade intelectual do bebê, através da qual, as falhas de adaptação do ambiente "tornam-se aceitáveis, compreensíveis, toleráveis, e mesmo previsíveis" (WINNICOTT, 2000, p.312).

O autor esclarece que essa compreensão intelectual no bebê vai transformando a adaptação não-suficientemente boa em uma adaptação suficientemente boa. O que implica dizer que o bebê em um certo ponto de seu desenvolvimento se encontrará em posição e condição de lidar com as falhas maternas, suportará algumas frustrações, mas, sempre considerando suas capacidades em crescimento.

Assim, a capacidade de adaptação contempla a capacidade de desadaptação, pois o crescimento do bebê permite que a relação de cuidados, inicialmente absoluta, possa ir se relativizando, portanto, com as novas capacidades do bebê, outras necessidades se apresentam. E a mãe, até então, completamente envolvida com o bebê, pode ir propondo outras formas de relacionamento, bem como, pode favorecer que o bebê vivencie suas recém-conquistadas capacidades. Ela vai introduzindo o mundo ao bebê e o bebê no mundo.

O saber da mãe é outro ponto discutido pelo autor, entendido como um saber que não é da ordem daquilo que pode ser ensinado ou aprendido, mas algo que já constitui a mulher, algo que foi experienciado quando ela era um bebê e, como tal, foi cuidada. E por acompanhar ou partilhar da experiência de outros adultos cuidando de seus filhos ou mesmo tendo a experiência de auxiliar no cuidado de crianças menores. 
de seus irmãos; acima de tudo, porém, ela aprendeu muitas coisas de importância vital quando, ainda muito novinha, brincava de pai e mãe (WINNICOTT, 2006, p. 52).

Assim, o autor entende que esse saber que a mãe possui na relação de cuidados com o bebê não pode vir do conhecimento intelectual, mas da experiência de algo que se formou na relação de cuidados que viveu com outras pessoas. Um saber que se entrelaça na experiência pessoal e precisa ser vivido para ser construído, um tipo de saber psicossomático, pois é tecido nas relações de cuidado que se inscrevem tanto no corpo como na psique. Daí decorre que "as principais coisas que uma mãe faz com seu bebê não podem ser feitas através de palavras" (WINNICOTT, 2006, p. 53).

É recorrente encontrar nos textos de Winnicott advertências aos profissionais que trabalham com mães e seus bebês, principalmente os profissionais da área da saúde, justamente, no que tange a interferências na relação de cuidados que se estabelece entre a dupla.

\footnotetext{
O que podemos fazer como médicos e enfermeiras é evitar interferências. Trata-se de algo realmente simples. Temos que saber qual é a nossa especialidade, e temos que saber exatamente de que forma as mães realmente necessitam de cuidados de médicos e enfermeiras. De posse desse conhecimento, facilmente deixamos a cargo da mãe exatamente aquilo que ela é capaz de fazer sozinha (WINNICOTT, 2006, p. 56).
}

Há ênfase em deixar que a mãe possa cuidar de seu filho, sem interferências, ou seja, sem que ela precise ser ensinada ou instruída nesse cuidado. A relação de cuidado recai para aquelas parcelas de coisas que podem ser feitas de forma comum. Direciona-se o olhar para algo que precisa acontecer de modo simples, comum, ou seja, o envolver-se com o bebê.

O envolvimento é da ordem das relações espontâneas, um modo de relacionar-se que prescinde dos conhecimentos (intelectuais, técnicos etc.) que, algumas vezes, podem gerar um engessamento, impossibilitando que os cuidados tenham suas origens nas necessidades identificadas no contato da mãe com o bebê.

Observamos muito exemplos desse tipo na quantidade de livros existentes que ensinam a cuidar dos bebês, que trazem em forma de manual, regras, procedimentos e instruções para algumas situações. Ainda, cotidianamente, sabe-se de pediatras que ditam, sob a forma de orientação, procedimentos que em nada favorecem o desenvolvimento psíquico saudável dos bebês e, ainda, contribuem para um aumento da angústia e insegurança dos pais. 
Recentemente, em contato com amigos que tem um filho pequeno, soube que o pediatra orientou o casal a não pegar o bebê ao colo em todos os momentos que ele chorasse, que deixassem o bebê chorar no berço ou no carrinho para que ele não ficasse mal acostumado, ou se preferir, mimado.

De fato, o bebê foi deixando de chorar, mas ocorre também, que foi ficando muito apático, não chorava, mas também não solicitava o colo, não estendia mais seus bracinhos na direção dos pais, não olhava para eles, estava ficando desinteressado pelo contato com seus pais.

Felizmente, os pais mudaram o rumo dessa história e passaram a pegar o filho quando ele chorava. Hoje, é possível ver o bebê esticando seus braços para ir ao colo dos pais, ele sorri, procura com olhinhos vivos as pessoas ao seu redor e mostra gostar muito de estar entre elas...

Adicionamos mais uma ilustração que pensamos não carecer de maiores explicações do que estamos tentando indicar. No livro DOSSIÊ AUTISMO, há o depoimento de uma mãe de uma criança que aos 3 anos e seis meses foi diagnosticada com autismo. Ela relata que o filho nasceu saudável após uma gestação "biologicamente perfeita”. Em suas palavras a mãe diz:

Foi gerado após um aborto espontâneo e sua gestação foi cercada de todos os cuidados pelo obstetra e por mim. Nos primeiros três meses de vida não percebi qualquer diferença no bebê comparado com outros que conhecia. Devo salientar que li em certo livro orientações sobre como minimizar os efeitos das terríveis cólicas nos recémnascidos. Este livro preconizava que as mães não deveriam, de forma alguma, olhar nos olhos dos seus bebês até que o período das cólicas passasse. Sendo assim, as cólicas foram bem suaves, mas eu não sabia se meu filho interagia comigo ou não ${ }^{7}$. João Paulo era muito tranquilo, dormia muito e chorava pouquíssimo. Eu o mantinha a maior parte do tempo agarrado a mim, como "mãe canguru". Após esta fase, aos seis meses, mais ou menos, percebia que ele se manifestava pouco. Não procurava contato visual, sorria só quando muito estimulado e apresentava certa fragilidade muscular (SILVA, 2015, p. 359).

Pensamos que ações como observar e descrever são úteis e necessárias para indicar os caminhos que desenvolvimento está percorrendo, mesmo que intervenções sejam necessárias, é imprescindível que sejam pensadas e pautadas por essas ações, para que o ato de intervir seja contextualizado e para o bem.

\footnotetext{
${ }^{7}$ Grifo meu.
} 


\subsubsection{Preocupação Materna Primária e Intimidade}

"há algo, aqui, que as pessoas chamam de identificação primária. Isto é o começo de tudo, e confere significado a palavras muito simples, como ser"

A Preocupação Materna Primária é vista como esse estado momentâneo em que a mãe se encontra totalmente dedicada ao seu bebê recém-nascido, onde ele passa a ser o centro da vida dessa mulher. Como mencionamos anteriormente, esse descentramento é caracterizado por uma espécie de retraimento ou dissociação, uma sensibilidade exacerbada. Às vezes, pode-se ver instabilidade, a mulher apresenta-se antissocial ou irritável, quase um estado de adoecimento, no qual outros interesses, que não o bebê, ficam excluídos, mas, do qual a mulher se recupera transcorrido algum tempo.

É descrito como quase uma doença "porque a mulher deve ter saúde suficiente tanto para desenvolver esse estado quanto para recuperar-se dele à medida que o bebê a libera" (WINNICOTT, 2000, p.401).

Nota-se que, visto fora do contexto de maternidade, esse estado de retraimento da mulher, poderia facilmente ser compreendido como uma forma de adoecimento que merecesse atenção e cuidado, mas nesse cenário é parte integrante do relacionamento da mãe com seu bebê.

Winnicott tem um modo muito particular de se dirigir às mães nesse estado, utilizando as expressões dedicada, devotada ou mãe devotada comum, para identificar as mulheres em que é possível encontrar essas alterações. Segundo ele, a essas mulheres uma adaptação sensível e delicada as necessidades do bebê, seria possível a partir dos primeiros momentos.

E, essas mudanças se desdobrariam a partir da descoberta da gravidez, período em que a mulher poderá mudar sua orientação em relação a si e ao mundo e, se preocupar com as mudanças em seu próprio corpo e no interior dele. Vê-se que "de várias formas ela é encorajada por seu próprio corpo a ficar interessada em si própria. A mãe transfere algo de seu interesse em si própria para o bebê que está crescendo dentro dela" (WINNICOTT, 1983, p. 52).

\footnotetext{
${ }^{8}$ Winnicott, 2006, p. 09
} 
Dethiville (2011) destaca que Winnicott parecia intuir o que a medicina de hoje vem tentando verificar, ou seja, papel do hormônio ocitocina que se apresenta no momento do parto e sua contínua produção, dilatada para pós-nascimento, coincidindo com os períodos iniciais de cuidados maternos ao bebê. Esse é apenas mais um elemento que aponta para esse tipo de “disposição psíquica” que parece existir na mãe ao estar com seu bebê.

Observa-se que essa adaptação sensível é a capacidade que a mãe tem de identificar-se com o bebê e saber o que ele precisa, quais são as necessidades, podendo se colocar no lugar do bebê. Enfim, a mãe sente o que é a necessidade do bebê. Esse saber diz respeito a coisas muito simples como o momento em que o bebê precisa ser segurado ao colo, mudado de posição ou ser colocado no berço, ser acariciado, além de ser alimentado (WINNICOTT, 1983).

Estando a mãe em dedicação a seu bebê, o que se coloca como importante é a continuidade dos cuidados que facilitam o processo de integração da personalidade do bebê, a confiança que se estabelece e favorece um sentido de previsibilidade ao que acontece na relação mãe e bebê, a própria adaptação, permite que o bebê possa se estender em direção ao mundo e à independência, à medida que suas necessidade em constante transformação são satisfeitas e, por fim, essa provisão fortalecendo o impulso criativo do bebê.

Nesse momento inicial, o que se vê a partir dessa forma de contato da mãe com o bebê é o atendimento de necessidades que não se reduzem aos impulsos instintivos. O que se coloca em jogo, não é tanto a satisfação ou a frustação erótica, mas a possibilidade de ser do bebê, o estabelecimento da subjetividade. Destaca-se que "a descrição das necessidades emocionais do lactente alude a inúmeras "coisas vitais", que poderiam ser sintetizadas, em termos gerais, como necessidades de comunicação com outro humano, de ser visto e cuidado, de contato íntimo, corporal e afetivo" (LEJARRAGA, 2012, p.23).

Winnicott ressalta que o atendimento da necessidade em condição de dependência é fundamental e a "necessidade ou é resolvida ou não, e a consequência não é a mesma que a satisfação ou frustração de um impulso do id” (WINNICOTT, 2000, p. 400).

A importância, nesse período, é que se reconheça a condição de dependência em que o bebê se encontra, por um lado e, a identificação da mãe com o bebê, por outro; o que revela uma enorme diferença em termos psicológicos entre a mãe e o bebê. Isso ajuda a entender que, a condição de dependência inicial não implica em identificação por parte do bebê, fenômeno este muito sofisticado para quem ainda não é! 
Ao mencionar a situação de dependência inicial e o processo de identificação primária, Winnicott (2005) alerta que está falando de bebês que estão para nascer, os recém-nascidos e aqueles de poucas semanas ou meses e, que bebês por volta de seis meses de idade já estariam deixando essa condição.

\begin{abstract}
A identificação é aqui aquilo com que a criança começa. Não significa que a criança se identifica com a mãe, mas que não há conhecimento da mãe ou de qualquer objeto externo ao self; e mesmo essa afirmação não pode ser considerada correta, pois não existe ainda um self. Poder-se-ia dizer que, neste estágio, o self da criança é apenas potencial (WINNICOTT, 2005, p.25)
\end{abstract}

Ressalta-se que se trata de pensar que o bebê pequenino precisa diferenciar-se como "Não-Eu", o que implica considerar que é necessário que um Eu se forme para que seja possível começar a estabelecer relações com ele mesmo e com o mundo.

O argumento é que somente será possível falar em satisfação ou frustação instintual quando houver um ser humano para vivê-las, ou melhor, quando as bases da constituição psíquica, estiverem alicerçadas e houver um ego rudimentar ou um Eu que possa se relacionar com questões instintuais.

Portanto, estamos falando do início da formação egóica no bebê. Uma formação que se dá de forma silenciosa e deriva de experiências de ameaça de aniquilação sentidas pelo bebê, mas que não chegam a se efetivar, pois o bebê se recupera dessas experiências. "A partir dessas experiências, a confiança na recuperação começa a transformar-se em algo que leva ao ego e à capacidade do ego de suportar frustrações” (WINNICOTT, 2000, p.404).

A adaptação da mãe as necessidades do bebê permitem que o desenvolvimento transcorra em bases contínuas. O bebê recebe cuidados que favorecem a construção de um sentido de continuidade, de estar sendo ao longo do tempo, sem que saiba da existência de um ambiente de cuidados (externo). Quando há quebras desses cuidados ou intrusões o bebê reage a essas irritações, e isso traz um sentido de ameaça de aniquilação de sua existência. Dessa forma, o sentido de continuidade de ser está ligado ao fortalecimento ou enfraquecimento da força do ego no bebê (WINNICOTT, 1983).

Assim, o conceito de ego em Winnicott equivale: 
quietude, e o estabelecimento da capacidade de esperar que haja recuperação depois das aniquilações; aniquilações resultantes das reações contra as intrusões do ambiente (WINNICOTT, 2000, p.405).

Em um texto de 1962, "A integração do ego no desenvolvimento da criança” o autor apresenta outra definição dizendo: "pode-se usar a palavra ego para descrever a parte da personalidade que tende, sob condições favoráveis, a se integrar em uma unidade" (WINNICOTT, 1983, p. 55).

Abriremos um parêntese para fazer uma breve distinção entre os termos ego, eu e simesmo, ambos utilizados pelo autor, aparecem em nosso texto, mas não são sinônimos.

Observa-se que as experiências acumuladas pelo bebê em seu desenvolvimento constroem as bases de formação do ego. O ego, dessa forma, seria o organizador das experiências tanto instintivas quanto objetivas. O ego é, então, a parte da personalidade que tende a se integrar em uma unidade, talvez, se pudesse dizer, é aquele que direciona a tendência à integração no sentido da formação de um si-mesmo. E, está pautado em um sentido corporal, pois quando tudo vai bem, o bebê se relaciona com o próprio corpo e suas funções, sentindo a pele como uma membrana, um contorno entre ele e o mundo.

Sendo ainda, o ego que inicia as relações objetais, se pode dizer que se refere a parte do ambiente que oferece apoio ao ego incipiente do bebê, possibilitando o seu fortalecimento ou enfraquecimento rumo a organização pessoal em um si, portanto, o ego surge no bebê antes que o termo si-mesmo adquira importância.

O termo "eu" é colocado pelo autor como algo que se diferencia do ego. Vejamos.

Para mim o eu, que não é o ego, é a pessoa que eu sou, que somente eu posso ser, que possui uma totalidade baseada no funcionamento do processo de amadurecimento. Ao mesmo tempo, o eu é constituído de partes, é formado por essas partes. Essas partes aglutinam-se na direção de dentro para fora, no decorrer do processo de amadurecimento, ajudadas, como precisam ser (no início, ao máximo), pelo ambiente humano que sustenta e maneja e facilita as coisas de uma maneira viva. O eu encontra a si mesmo situado naturalmente dentro do corpo mas, em certas circunstâncias, pode vir a dissociar-se do corpo no olhar da mãe e em sua expressão facial, e no espelho, que pode vir a representar o rosto da mãe. Em algum momento o eu chega a um relacionamento significativo entre a criança e a soma das identificações que (depois de uma quantidade suficiente de incorporações e introjeções de representações mentais) tornam-se organizadas na forma de uma realidade psíquica interna viva (WINNICOTT, 2000, p. 42). 
Winnicott parece querer mostrar que o "eu" diz respeito ao sentido de diferenciação que o bebê alcança com a integração, refere-se ao momento onde é possível diferenciar o $e u$ do nãoeu. Aparece um assentamento no corpo experimentado como sede do "eu", já podendo estabelecer relações entre dentro e fora, entre o eu e o mundo. $\mathrm{O}$ "eu", nesse sentido, indicaria um momento mais avançado na linha de amadurecimento, talvez, poderíamos dizer, ele resulta do sentido de continuidade que permite o estabelecimento suficiente do ego.

Quanto ao termo si-mesmo, em linhas gerais podemos dizer que ele é utilizado como termômetro para localizar diferentes graus ou formas de integração que o bebê vai experimentando ao longo do processo de amadurecimento, mesmo que de forma muito inicial ou momentânea (DIAS, 2003).

Também é empregado por Winnicott para dizer do alcance do status de unidade, em um momento onde o bebê, se pudesse, diria: Eu sou, onde já se teria a possibilidade de encontrar um eu, nesse sentido, pode ser entendido como um eu que já se separou da mãe.

Vimos até aqui, o quanto Winnicott enfatiza o papel da mãe no desenvolvimento do bebê, particularmente quando fala desse estado especial da mãe, a Preocupação Materna Primária.

A essa altura, pensar sobre essa dedicação necessária ao bebê pode afugentar algumas mulheres que não são mães e despertar algo do tipo: que trabalheira!!! Ao mesmo passo, provocar em mães certa inquietação...quanta exigência!

Isso tudo parece terrível?

Nem tanto! É fundamental mencionar que para Winnicott, essa adaptação tem vida curta! Não esquecendo que o bebê está em desenvolvimento, o que significa que a atividade mental do bebê também está crescendo e, com ela a capacidade de suportar as falhas do ambiente.

Contudo, ele também é contundente ao argumentar que essa condição especial não está presente, melhor dizendo, não se apresenta em todas as mulheres. E, ainda assim, muitas mulheres continuam sendo boas mães em diversos outros aspectos, porém, "não têm a capacidade de contrair essa 'doença normal' que lhes possibilitaria a adaptação sensível e delicada às necessidades do bebê já nos primeiros momentos. Ou conseguem fazê-lo com um filho e não com outro" (WINNICOTT, 2000, p.401). 
Considera que as mulheres que não podem se preocupar com seus bebês de modo a abandonarem temporariamente outros interesses, sugerem a possibilidade de imaginar que elas tenderiam a se abrigar na sanidade para não adoecer nessa condição materna. Outras, apesar de realmente terem motivos concretos a se preocuparem não os excluem prontamente ou, talvez, não até serem mães pela primeira vez.

Sugere ainda que, em mulheres com uma forte identificação masculina pode ocorrer que a posição materna e as funções que a correspondem possam ser sentidas como mais difíceis de serem realizadas e "uma inveja do pênis reprimida deixa muito pouco espaço para a preocupação materna primária" (WINNICOTT, 2000, p. 402).

Ainda que considere a mãe como a pessoa mais esperada para essa posição, ele também considera que outras pessoas possam se ocupar desse lugar de cuidados de maneira adequada.

Em seu próprio dizer lê-se "já a mãe adotiva, ou qualquer outra mulher capaz de ficar doente no sentido da 'preocupação materna primária', estará possivelmente em condições de adaptar-se suficientemente bem, na medida da sua capacidade de identificar-se com o bebê" (WINNICOTT, 2000, p.404).

Isso nos leva a pensar que algum grau de identificação pode surgir em pessoas que estão em contato com bebês, mesmo que estas não sejam mães ou mesmo mulheres. Outras pessoas podem identificar-se com as necessidades de um bebê, desde que sintam o que é necessário ao bebê em dado momento. Sobre isso, argumenta o autor, "devemos nos organizar de modo que em cada caso haverá alguém com tempo e inclinação para saber o que a criança precisa" (WINNICOTT, 1983, p.68).

Com base nisso, podemos destacar três pontos: o primeiro, é preciso que haja alguém presente e com tempo para estar com a criança; o segundo, a existência de interesse da pessoa envolvida no cuidado pela criança em questão e, por último, a disponibilidade em conhecer a criança com quem se dá o contato.

Pensando em termos de presença e tempo, interesse e disponibilidade em conhecer o bebê, podemos imaginar que algum saber sobre a criança se constituirá e com ele também, a origem de algum tipo de identificação.

Assim, "a identificação com a criança não precisa ser tão profunda como a da mãe com o recém-nascido, exceto naturalmente, quando a criança considerada está doente - imatura ou deformada emocionalmente, ou incapacitada por alguma doença física" (WINNICOTT, 1983, p. 68). 
Aponta-se para a questão de não ser demasiadamente necessário um conhecimento teórico sobre o desenvolvimento infantil, mas é de absoluta importância conhecer a pessoa do bebê e suas necessidades de forma a garantir os cuidados e o tratamento da criança tal qual ela é... Como bebê!

A esse respeito, Dethiville (2011) acrescenta que "além da mãe, outra pessoa pode garantir essa função, a partir do momento em que é possível manter uma continuidade" (p. 60). A autora destaca ainda que Winnicott chamava essa possibilidade de ambiente suficientemente bom, onde o que realmente importa é a redução dos prejuízos na linha de continuidade da vida da criança que, em algum ponto precisará estar em contato com os contratempos do ambiente e reagir a eles.

Outro aspecto a considerar no desenvolvimento se refere à mutualidade ou intimidade entre a mãe e o bebê. A mutualidade "é o começo de uma comunicação entre duas pessoas" (WINNICOTT, 1994, p.198).

A mutualidade é a resultante das identificações cruzadas entre o bebê e a mãe. E, essa intimidade é alcançada de formas diferentes para o bebê e para a mãe. A identificação materna vem do fato dela mesma ter sido um bebê que recebeu cuidados, ela brincou de bonecas, brincou de bebê e de mãe, talvez tenha tido irmãos, cuidou de bebês, ou aprendeu observando alguém cuidar, enfim, viveu experiências de cuidar e ser cuidada, que possibilitam assumir posição de cuidados em relação aos bebês.

Contudo, o bebê está sendo cuidado pela primeira vez, portanto, não tem como saber nada sobre cuidados, sendo possível a ele identificação primária apenas na experiência de mutualidade. Essa experiência de intimidade não envolve diretamente os impulsos ou questões instintuais. Assim, "a coisa principal é uma comunicação entre o bebê e a mãe em termos de anatomia e fisiologia de corpos vivos" (WINNICOTT, 1994, p.200).

A intimidade é uma comunicação que nasce no contato corporal entre a mãe e o bebê, diz respeito a toda centelha de vida, tais como a respiração, o toque, o calor do corpo etc. $\mathrm{O}$ contato íntimo estabelecido pelos cuidados do bebê é uma forma importante de comunicação, uma comunicação silenciosa. "A comunicação é uma questão de reciprocidade na experiência física" (WINNICOTT, 2006, p. 89).

A mutualidade ou intimidade é toda a forma de comunicação que prescinde do uso das palavras. Embora os sons verbais possam estar presentes no contato da mãe com o bebê, importa 
mesmo o tom e a atitude com que são enunciados. Visto por este ângulo, "a verbalização perde todo e qualquer significado" (WINNICOTT, 2006, p.81).

Destaca-se, então que, em relação a mutualidade e essa maneira de comunicação, a mãe pode recuar às experiências infantis, uma vez que tal possibilidade diz respeito a sofisticação do desenvolvimento adulto. No entanto, ao bebê esta condição não está disponível, pois ele está fazendo experiências pela primeira vez, ele está sendo um bebê...

Para ele, tudo é uma primeira experiência, inexistindo qualquer medida para julgamento ou comparação. O tempo não se mede tanto por relógios, pelo nascer ou pelo pôr-do-sol, quanto pelo ritmo do coração e da respiração maternos, pela elevação e quedas das tensões instintivas, bem como por outros dispositivos essencialmente não-mecânicos (WINNICOTT, 2006, p. 84).

Não se pode deixar de mencionar o brincar como fato importante na comunicação entre a dupla. Nos momentos de intimidade entre o bebê e a mãe desenvolvem-se brincadeiras, principalmente nos momentos de amamentação, tempo e espaço propício para a comunicação, “onde nascem a afeição e o prazer pela experiência" (WINNICOTT, 2006, p.89).

Winnicott (1994) chama atenção que a ocorrência dessa comunicação pode ser vista inicialmente no contexto de alimentação. Destaca que, embora não se possa afirmar com certeza, nota-se que mesmo um bebê de poucas semanas, observa o rosto materno de forma significante. Por volta de 12 semanas, os bebês podem nos mostrar que a comunicação é um fato.

Explica que os bebês apresentam variações consideráveis em seu ritmo de desenvolvimento, especialmente quando se trata dos fenômenos que são observáveis. Ainda assim, diz que bebês, por volta de doze semanas podem brincar. E descreve o brincar contando que "instalado para mamar, o bebê olha para o rosto da mãe e a sua mão se levanta, de maneira que, de brinquedo, ele está amamentando a mãe por meio de um dedo que coloca na sua boca" (WINNICOTT, 1994, p.198).

Continua seu argumento, considerando que a mãe bem pode contribuir para essa brincadeira, facilitando sua ocorrência, o que não invalida o fato de que um brincar pode estar em curso. Além disso, enfatiza que, embora todos os bebês possam ingerir o alimento, não se estabelece uma comunicação entre a dupla, a não ser que se desenvolva uma experiência de alimentação mútua. 
Agora vale a pergunta: o que é comunicado nessa relação de intimidade?

A mãe ao cuidar do bebê faz muitas coisas, mas uma em especial é comunicada à medida que o desenvolvimento avança e o bebê conquista os sentidos de interior e exterior: a confiança. O que o bebê registra dessa comunicação é o efeito de confiabilidade do ambiente. "A sustentação confiável de um bebê é algo que precisa ser comunicado, e isto é questão das experiências do bebê" (WINNICOTT, 1994, p.202).

Os cuidados maternos não são absolutos, há momentos em que a mãe falha e na sequência corrige seus erros. Essa alternância entre falhas e cuidados é a ocasião para o bebê desenvolver uma sensação de segurança e confiança. Assim, esse vaivém possibilita ao bebê o registro da confiabilidade, porque sem erros não há acertos, e não há como conhecer os cuidados e o amor. Essas falhas não geram raiva no bebê, pois ele possui uma constituição insuficiente para tal vivência, o que elas produzem são angústias, as agonias impensáveis (LEJARRAGA, 2012).

Dessa forma, o fato fundamental na comunicação silenciosa da mãe para o bebê é a confiabilidade. E, esta é importante porque protege o bebê de reagir às intrusões do ambiente, ou da realidade externa. As intrusões ambientais se constituem como rupturas da experiência de continuidade de vida do bebê, fonte geradora de traumas, por vivências das agonias impensáveis.

E a comunicação do bebê? $\mathrm{O}$ fato mais evidente seria dizer que o bebê comunica seu desamparo, mas, apesar disso, o bebê possui intensa potência de vida. Isso leva a considerar que nessa relação de intimidade, a comunicação do bebê estaria circunscrita ao impulso em direção a algo, um gesto espontâneo do bebê e sua capacidade criativa.

O contexto de intimidade que se desenvolve entre a mãe e o bebê é possível pela capacidade adaptativa da mãe, tendo como pano de fundo a preocupação materna primária. Enfatiza-se que um dos aspectos marcantes na relação com o bebê, também alicerce do desenvolvimento do sentido de segurança e confiança é a capacidade de sustentação nos cuidados maternos: o holding. 


\subsubsection{Holding e Handling}

"Um holding satisfatório é uma porção básica de cuidado"9

Verifica-se então que o holding se relaciona, diretamente, com a capacidade de identificação da mãe com seu bebê. Observa-se que a identificação da mãe com seu bebê traduzse pelos cuidados que ela dispensa a ele.

Os cuidados maternos se referem ao campo das ações da mãe, são mesmo cuidados físicos, são tarefas de natureza física, portanto, referem-se a amamentação, banhos, trocas, dar colo, aspectos do cuidado concreto que formam um conjunto de experiências que se desenham como aspectos psíquicos no bebê (WINNICOTT, 1983).

Uma descrição de holding incluiu o atendimento de aspectos de natureza fisiológica, os aspectos de natureza sensorial (tato, temperatura, sensibilidade auditiva, sensibilidade visual, sensibilidade à queda, incluindo ação da gravidade) e abarca a falta de conhecimento da existência de qualquer outra coisa que não seja si mesmo, por parte do bebê.

Leva em conta toda a rotina de cuidado diurno e noturno e as mudanças cotidianas que integram tanto o desenvolvimento físico quanto psíquico do bebê que são notadas pela mãe.

As rotinas de cuidados diurnos e noturnos se pautam pela,

\footnotetext{
...monotonia periodicamente regulada da mesma experiência que permite à criança encontrar referências a partir das quais sua capacidade de esperar (portanto, o começo do pensamento) pode ser elaborada. É preciso levar em conta o tempo, a repetição e a constância, a infinita monotonia da volta ao mesmo. Mais tarde, a lembrança de todas as manhãs não virá mais. Ficará a lembrança do dia em que alguma coisa aconteceu que tornou a experiência diferente (DETHIVILLE, 2011, p. 63).
}

Por isso, o autor insiste em afirmar que esses cuidados são uma forma de amar, dizendo que o holding "é possivelmente a única forma em que uma mãe pode demonstrar ao lactente o seu amor" (WINNICOTT, 1983, p.49).

\footnotetext{
${ }^{9}$ Winnicott, 2005, p. 26-27.
} 
Com isso, aponta que o holding é uma forma de sustentação que descreve esses cuidados básicos que estamos mencionando, ou seja, tudo que uma mãe faz no cuidado de seu bebê, incluindo a necessidade de colocá-lo no berço, espaço que proporciona a experiência impessoal de sustentação.

Afirma que evidências dos cuidados maternos que circunscrevem o holding e se inscrevem como aspectos vitais podem ser vistos no ato de segurar e manusear o bebê, o que ele entende como experiências tão importantes como a experiência concreta de amamentação.

\begin{abstract}
No início, porém, é o ato físico de segurar a estrutura física do bebê que vai resultar em circunstâncias satisfatórias ou desfavoráveis em termos psicológicos. Segurar e manipular bem uma criança facilita dos processos de maturação, e segurá-la mal significa uma incessante interrupção destes processos, devido às reações do bebê às quebras de adaptação (WINNICOTT, 2006, p. 54).
\end{abstract}

Com o ato de segurar ou sustentar bem o bebê, a mãe facilita o desenvolvimento da confiabilidade ambiental, a partir daí a criança adquire confiança no mundo, pode sentir que o mundo é um lugar seguro. E mais, por ter sido sustentado de modo seguro, o bebê torna-se capaz de percorrer seu processo de amadurecimento mais rapidamente, pois as bases que o constituem psiquicamente foram bem assentadas.

Nesse sentido, holding também pode ser compreendido como "tudo aquilo que, nesta ocasião, a mãe é e faz" (WINNICOTT, 2006, p. 4). Aquilo que ela é, significa ser o ambiente, ser facilitadora ao se adaptar ativamente as necessidades básicas do seu bebê; já o fazer se liga as inúmeras tarefas de cuidados concretos e sutis com e para o bebê.

É possível dizer que, na experiência comum de segurar adequadamente o bebê, a mãe foi capaz de atuar como um ego auxiliar, de tal forma que o bebê teve um ego desde o primeiro instante, um ego muito frágil e pessoal, mas impulsionado pela adaptação sensível da mãe, e pela capacidade desta em identificar-se com seu bebê no que diz respeito às suas necessidades básicas (WINNICOTT, 2006, p. 31-32).

Nota-se que holding é um termo usado tanto para falar dos modos como algumas mães seguram seus bebês nos braços, como também, em sentido mais abrangente abarca os aspectos psicológicos que podem se apresentar na relação da mãe com o bebê (LINS, 2006).

A realização do holding e do handling (manejo) pela mãe facilita que as tarefas pertencentes ao desenvolvimento possam ter curso, além do que, ao permitir que o bebê tenha 
experiências de ser bem sustentado, a confiabilidade do bebê no ambiente se desenvolve, pois é como se, ao bebê fosse comunicado: você possui um corpo e esse corpinho é constituído de várias partes que se seguradas em conjunto, se reunidas, oferecem a sensação de unidade; há momentos que você precisa mudar de posição, ser levantado, e nessa hora um tipo de apoio específico é necessário e todos esses gestos começam, tem continuidade e terminam.

Atravessando seu crescimento com essa sustentação o bebê pode experimentar a continuidade de sua existência, sempre pautada no apoio ambiental que constitui e fortalece o ego em desenvolvimento.

\begin{abstract}
Esse segurar, que é simples e se refere ao manuseio do bebê e a todos os cuidados físicos relativos ao seu bem-estar, vai aos poucos se ampliando à medida que o bebê cresce e que seu mundo vai se tornando mais complexo. Estendendo-se para os cuidados em geral, incluindo a atmosfera de calma e regularidade do ambiente que a mãe é capaz de manter, o "segurar" amplia-se para um "sustentar a situação no tempo" (holding a situation), que é uma disponibilidade tranquila que permanece, que se estende demoradamente no tempo e não exige que nada aconteça; apenas aguarda os movimentos do bebê e o acompanha em suas inúmeras idas e vindas (DIAS, 2003, p. 207).
\end{abstract}

De acordo com essa compreensão, nota-se que holding significa os cuidados em geral com o bebê e, também toda a manutenção do ambiente, uma vez que, os cuidados da mãe visam a garantir a regularidade e, ao mesmo tempo, a presença de vida ao lugar. A mãe respeita dos momentos de descontinuidade e apresenta-se nos momentos que o bebê se coloca em contato, enfim, ela segura temporalmente essa situação.

Esse tipo de sustentação, que implica segurar, mas também se prolonga para além desse ato, permite ao bebê, que experimenta um sentido de confiança no ambiente, ou se preferir, nos braços de quem o segura, um tipo de relaxamento onde o bebê poderá experimentar algo muito valioso, retomar um estado de não-integração.

Daí decorre que o ato de segurar mal uma criança "força-a a ter uma consciência prematura para qual não está bem equipada" (WINNICOTT, 2006, p.37). Aqui, aponta-se que um bebê que não é bem sustentado começa a ter consciência prematura da existência da externalidade, ele pode entrar em um estado de alerta para evitar as perturbações do ambiente, não favorecendo que ele possa estar em estado de repouso e alheamento dos aspectos da realidade para qual ainda não está pronto para viver. 
A razão pela qual esta característica especial dos cuidados aos bebês deve ser mencionada, mesmo resumidamente, é que angústias muito fortes são experimentadas nos estágios iniciais do desenvolvimento emocional, antes que os sentidos estejam organizados, e antes que ali exista algo que possa ser chamado de um ego autônomo (WINNICOTT, 2006, p. 31).

No começo da vida, o bebê experimenta diversas sensações corporais as quais ele não conhece, não sabe o que são e que fazem parte dele, também experimenta muitas experiências no contato com o corpo da mãe e seus cuidados, além dos aspectos do ambiente. São muitas coordenações de aspectos sensório-motores e de contato com o ambiente que o bebê ainda não organizou, o que faz pensar que o bebê pode estar exposto a angústias muito intensas que ele não pode suportar. Essas angústias muito iniciais são nomeadas agonias impensáveis e, é delas que o bebê necessita ser poupado e protegido para que seu desenvolvimento não sofra com rupturas.

Sobre essas agonias, o autor diz que "a palavra angústia é inútil, pois o tipo de aflição que o bebê sente neste estágio é muito parecido ao que se encontra por trás do pânico, e o pânico já é uma defesa contra a agonia [...]” (WINNICOTT, 2006, p. 31).

O autor mostra a importância dos cuidados com o bebê para que essas vivências de agonia não se instalem e atravanque o amadurecimento e desenvolvimento das relações com objetos e o mundo. Assim, delimita-se que a ansiedade mais longínqua pode se relacionar ao fato do bebê ter sido seguro de modo inseguro, sendo assim, "o protótipo de todos os cuidados com o bebê é o ato de segurar" (WINNICOTT, 2006, p. 30).

$\mathrm{O}$ ato de segurar bem um bebê permite que não se instale os modos de ansiedade caraterísticos das falhas de cuidados, quais seriam: a desintegração, despersonalização e o sentimento de vazio, como nada no centro. A desintegração compreenderia os aspectos de não sentir-se real e existente. Por despersonalização se compreende a ausência de relacionamento entre psique e o corpo (soma) e, finalmente, o termo nada no centro seria a sensação de deslocamento do centro para as fronteiras do corpo, para a superfície ou casca, desencadeando uma preocupação intensa com os cuidados de si.

Essas três modalidades, nas quais as agonias se apresentam, trariam um mal-estar que poderiam ser traduzidas em sensações de queda no vácuo, sensação de perda de equilíbrio (vertigens), irrealidade, inutilidade, perda da capacidade de se relacionar com objetos, entre outras (WINNICOTT, 1994). 
É possível perceber que o holding e o handling estão circunscritos ao âmbito dos cuidados com o bebê, especialmente dos cuidados com o corpo e a urdidura humana desse bebê, qual seja? A pessoa do bebê alcançando o estatuto de ser!

Assim, tais cuidados nos remetem ao imbricamento que possuem com as tarefas do amadurecimento, sobre isso, destaca-se que:

\begin{abstract}
O cuidado materno correspondente a essa tarefa de alojamento da psique no corpo é o manejo (handling). O manejar faz parte do segurar total (holding), mas refere-se especificamente ao segurar físico. No segurar-manejar devem estar incluídas todas as experiências sensórias necessárias: ser envolvido, por todos os lados, num abraço vivo, que tem temperatura e ritmo e que faz o bebê sentir tanto o corpo da mãe como o seu próprio corpo; ser aconchegado no berço de modo a permanecer tocado pelas mantas e almofadas e não solto no espaço; as inúmeras sensações táteis ao ser manejado de todas as formas, banhado, acariciado, afagado, cheirado etc.; diferenças sutis e graduadas de luminosidade, textura e temperatura; a oposição necessária para o bebê exercitar a motilidade; a resposta ativa e concreta para os estados excitados, tanto no que se refere à busca de algo quanto à satisfação instintual e motora (DIAS, 2003, p.209-210).
\end{abstract}

Mostra-se com isso, que o bebê precisa ser sustentado e manuseado para manter-se em contato com o próprio corpo, que estamos vendo, traduz-se em contato consigo mesmo. Essa forma de cuidado conserva o sentido de realização, ou seja, comunica a presença materna, a presença do mundo e, ainda, o sentido de habitar um corpo e estar vivo.

Portanto, também uma forma de comunicação e, "esta forma básica de comunicação física pode ser ilustrada através do movimento de embalar, no qual a mãe adapta os seus movimentos aos do bebê. Embalar é uma garantia contra a despersonalização, ou rompimento da combinação psicossomática" (WINNICOTT, 2006, p.88-89).

Grosso modo, a partir do exposto, podemos dizer que o ambiente facilitador do amadurecimento do bebê, pode ser desenhado por três linhas mestras: a sustentação, o manejo e a apresentação de objetos. Com uma facilitação ambiental nessas bases, o processo pode ser compreendido como integrador, somando-se a isso, a personalização e, posteriormente, o relacionamento objetal (WINNICOTT, 1994).

Até aqui, tratamos apenas da ideia que concerne ao holding. A partir de agora, faremos destaque ao handling, considerando que ambos os aspectos do cuidado se apresentam estreitamente ligados. 
O handling traduzido entre nós como manejo, se refere mais especificamente aos modos como a mãe manuseia o corpo do bebê durante os cuidados. O manejo engloba os gestos e ações de amamentação ou alimentação, os aspectos higiênicos como: troca de fraldas, banhos, vestir, bem como, os contatos corporais afetivos, como acariciar, beijar e abraçar.

Nota-se que o manejo diz das ações ou atos de cuidados da mãe que portam um jeito de apresentar ao bebê o corpo e a psique tanto do próprio bebê como da mãe. Portanto, não diz respeito a nenhuma técnica, digamos que, se assemelha mais ao modo de cuidar que inaugura um contato entre a dupla.

Dethiville (2011) assinala que ao manejar o bebê em seus cuidados, a mãe olha para o seu bebê e o vê como uma pessoa como ela, vê uma pessoa à sua imagem! Assim, "o que o bebê vê no olhar da mãe, pela maneira de ser manuseado, é o dom de viver essa totalidade que ela lhe dá" (p. 64).

O bebê ao ser manejado pela mãe experimenta o sentimento de ser reunido tanto nos braços como no olhar da mãe e, este sentimento de ser uno, inteiro, não estar mais espalhado e solto no espaço vai favorecendo o sentido de unidade.

O manejo descreve a provisão ambiental pelo meio que corresponde mais ou menos ao estabelecimento de uma associação psicossomática. Sem manejo ativo e adaptativo suficientemente bons, a tarefa interna pode vir a ser difícil, pode na verdade vir a ser impossível para o desenvolvimento de uma inter-relação psicossomática se tornar estabelecido adequadamente (WINNICOTT, 1983, p.60).

Como estamos vendo, adquirir o sentido espacial do corpo, o sentimento de habitar o corpo e ter um lugar vai se estabelecendo através das experiências de ser manejado pelos cuidados maternos. Ao mesmo passo que o bebê experimenta sensações corporais próprias e o contato com os cuidados e o corpo materno, ele elabora as experiências imaginativamente e estabelece uma associação entre o corpo e a psique, ambos em desenvolvimento.

De acordo com Dias (2003), o manejo seria esse cuidado realizado pela mãe que promove o estabelecimento dessa associação entre o corpo e a psique. Nessa perspectiva, "o manejar faz parte do segurar total (holding), mas refere-se especificamente ao segurar físico" (p.209).

O manejo favorece o sentido de ser do bebê, pois os cuidados além de promoverem associação psicossomática também facilitam a continuidade. O manejar da mãe permite reunir 
continuamente o bebê na experiência de habitar o corpo, mesmo que de início, momentaneamente. Assim, pode-se dizer que o manejo contribui para aquisição do sentido de continuidade da vida para o bebê, oferecendo a ele a oportunidade de ser e se integrar como pessoa.

\begin{abstract}
A continuidade da existência significativa passa por um gesto, por uma ação, por um manejo [...] que, partindo do objeto subjetivo, pela ilusão da criação do objeto, passa pelo objeto transicional e chega à percepção objetiva do mundo, percepção apoiada na capacidade de criar e brincar, surgida nesse mesmo espaço potencial (HAMMOUD, 2012, p.11).
\end{abstract}

Significa apontar que o manuseio do bebê favorece a parceira psicossomática e carreia com ela outros aspectos em amadurecimento, ou seja, a transição nos modos de relação com o objeto. Inaugurado na relação indiscriminada com a mãe, constituindo o objeto subjetivo, avançando para área intermediária, marcada pelas relações de objeto transicionais até a conquista do objeto compartilhado, que é diferenciado do bebê.

Portanto, o manejo “contribui para a formação do sentimento do 'real', por oposição a “irreal" (WINNICOTT, 2005, p.27). Como dissemos o contato com o sentido de morada no corpo conduz ao sentido de realidade, de ser real e da realidade do mundo.

A conquista do sentimento de morada no corpo traz a construção de dois novos aspectos no desenvolvimento do bebê, um se refere a ideia de casca limitadora que oferece contorno entre aquilo que é o bebê em seu corpo e o seu "mundo" e, aquilo que é externo ao corpo. Nesse sentido, surge a ideia de um centro e com ela, um sentido de "dentro" se constrói no bebê.

O argumento é que "o ser humano que agora passa a desenvolver uma entidade a partir do centro pode localizar-se no corpo do bebê, começando assim a criar um mundo externo ao mesmo tempo que adquire uma membrana limitadora e um interior" (WINNICOTT, 2000, p.166).

Finalmente, uma última compreensão que nos parece importante é olhar o manejo como uma forma de comunicação entre a mãe e o bebê, uma vez que os cuidados corporais cunham o conhecimento sobre o bebê e suas necessidades e, por ocasião dos cuidados o bebê também pode realizar comunicações pessoais com a mãe (LESCOVAR, 2004).

Mencionando o estabelecimento de uma comunicação como um aspecto do manejo do bebê, resgata-se a intimidade na relação entre a dupla, apontando para a multiplicidade de 
elementos presentes na relação de cuidados que aparecem imbricados no desenvolvimento do bebê, vislumbrando um processo que é sempre integrado e visa a integração.

Retomando o manejo como parte do holding, considera-se compreendê-lo para além do ato físico de segurar o bebê nos braços, a essa sustentação se relaciona um tipo de "provisão ambiental total anterior ao conceito de viver com" (WINNICOTT, 1983, p.44).

Como estamos vendo, ao atrelar o holding a facilitação de viver em relação com outros, verifica-se que esse tipo de cuidado está na base do processo de amadurecimento psicológico, diz respeito a possibilidade do bebê se destacar do estado de fusão com a mãe e perceber a existência de objetos como externos a ele.

Assim, o holding não se detém apenas ao caráter fisiológico do desenvolvimento, abarca também o caráter formativo, a saber, o universo psíquico e relacional humano. Desse modo, “esse holding garantido pela mãe-ambiente é físico, mas também - e principalmente - psíquico" (DETHIVILLE, 2011, p. 63).

Quando o bebê começa a separação da mãe, discriminando a sua existência como "nãoeu" e, a mãe sustentando essa situação vê as mudanças e as novas habilidades em seu bebê, opera uma mudança de qualidade na relação da dupla. A mãe altera sua adaptação, antes absoluta, uma vez que atendia as necessidades que ela conhece bem, e passa a aguardar os sinais do bebê que indiquem a necessidade, assim a comunicação entre eles se aprimora.

A relação apoiada na ampliação da capacidade de comunicação do bebê com a mãe, fortalece a separação do bebê da mãe e o auxilia no processo de discriminação.

\footnotetext{
Vemos portanto que na infância e no manejo dos lactentes há uma distinção muito sutil entre a compreensão da mãe das necessidades do lactente baseada na empatia, e sua mudança para uma compreensão baseada em algo no lactente ou criança pequena que indica a necessidade (WINNICOTT, 1983, p. 50-51).
}

Isso mostra que a capacidade de identificação da mãe com o bebê permite o conhecimento das necessidades dele, de maneira a capacitá-la oferecer o que o bebê precisa em termos de holding e adaptação ambiental, que em algum ponto significa facilitar a desadaptação gradativa, promovendo pequenas falhas para ajudar o bebê a conquistar a capacidade de lidar com frustrações. 
Claro, sempre considerando que as falhas precisam ser proporcionais a capacidade de o bebê suportá-las, ocorrendo na medida em que consegue assimilar e se beneficiar das falhas como um indicador do sentido de realidade crescente nele.

Nesse sentido, em "Os bebês e suas mães”, o autor descreve como as mães sentem-se responsáveis ao segurarem seus filhos pequeninos ao colo e nessa ação permanecem envolvidas de modo especial. Menciona que diante da solicitação de outras pessoas para segurarem seus bebês, essas mães não o permitem, ao menos que sintam confortáveis e confiantes em fazê-lo. Isto porque, as mães sabem como "os bebês são realmente muito sensíveis à maneira como são segurados, o que os leva a chorar com algumas pessoas e a ficar calmos e satisfeitos quando no colo de outras, mesmo quando são ainda muito novinhos" (WINNICOTT, 2006, p. 15).

O modo de segurar e manipular o bebê não necessita de perfeição ou orientação para ser realizado de modo satisfatório. Ele está baseado no conhecimento que a mãe adquire diariamente no contato com o bebê. Um cuidado que resulta dos erros e acertos que ela realiza junto ao filho.

Por isso, eles são suficientes e não perfeitos ou mecânicos, pois “à medida que prossegue o desenvolvimento e o bebê adquire um interior e um exterior, a confiabilidade do meio ambiente passa então a ser uma crença, uma introjeção baseada na experiência de confiabilidade (humana, e não mecanicamente perfeita)”(WINNICOTT, 2006, p. 87).

A confiabilidade é uma questão central no desenvolvimento, uma importante característica do ambiente que facilita o amadurecimento do bebê rumo à independência. Portanto, está estritamente ligada ao estado de dependência do bebê.

Vê-se então que "é só através da experiência repetida de confiabilidade ambiental que começam a ser constituídos os fundamentos do sentido de ser, de ser real e de poder habitar um mundo real" (DIAS, 2011, p.15).

Ao cuidar do bebê, a mãe se mostra previsível, ao manter-se ela mesma, consistente, regular e monótona, garantindo a regularidade e previsibilidade desse mundo inicial do bebê. Assim, o ambiente previsível,

[...] cuida para que não haja alterações na atmosfera do ambiente, e para que o manejo não seja brusco nem apressado; é ela, também, que preserva imperturbado o isolamento do bebê quando ele se retira para descansar. Ela permanece lá, sustentando a situação no tempo, aguardando que ele retome uma busca qualquer. Quando o bebê desperta e faz um gesto de comunicação, lá está ela apresentando um fragmento de mundo ou um manejo que confirmam, para ele, que o mundo continua presente e vivo. 
É a repetição monótona e regular dessa experiência que vai criando no bebê a capacidade de confiar (DIAS, 2011, p.23).

Com isso, pensamos ter mostrado como os cuidados que apresentamos como holding e manejo fazem parte do conjunto de cuidados maternos que constituem o ambiente como um todo, um ambiente total. Portanto, a partir desses cuidados, principalmente, do modo como esses cuidados são realizados "um mundo" para o bebê começa a ser desenhado.

A característica central do primeiro mundo onde o bebê habita é ser confiável. A confiabilidade materna não reside em nenhum fazer específico, mas no "como", no modo como ela faz e providencia as coisas que são necessárias ao bebê. Mais do que qualquer fazer, são os modos de ser da mãe que estão em questão (DIAS, 2011, p.21).

Vimos que holding e handling são formas de cuidados realizados pela mãe, parte da provisão ambiental oferecida por ela ao bebê enquanto se relaciona com ele como um ambiente. O ambiente é outro aspecto dos cuidados maternos.

\subsubsection{Ambiente e seus cuidados ou amor?}

A mãe, os cuidados e o ambiente, descritos separadamente são simultâneos, integrados e não lineares, talvez, não seja possível descrever como tal. Quem sabe, por nossa inabilidade em construí-lo de outra forma... Que o leitor não perca a esperança e acompanhe nosso percurso, em certa similaridade com movimentos de avanços e recuos que possibilitam a aquisição e o fortalecimento das conquistas no desenvolvimento.

A partir de agora, enfatizaremos como a relação de cuidados da mãe como um ambiente baliza a construção da subjetividade do bebê.

O fornecimento de um ambiente suficientemente bom na fase mais primitiva capacita o bebê a começar a existir, a ter experiências, a construir um ego pessoal, a dominar os instintos e a defrontar-se com todas as dificuldades inerentes à vida. Tudo isso é sentido como real pelo bebê que se torna capaz de ter um eu [...] (WINNICOTT, 2000, p. 404). 
Assim, o bebê precisa de um ambiente que ofereça condições para que um começo seja possível. Essas experiências de ser contínuas favorecem a construção de um ego e, a partir daí, as experiências instintuais são possíveis como tais, bem como, a formação do sentido de realidade também vai se consolidando no bebê.

Pretende-se esclarecer que por ambiente (mães ou pais) suficientemente bom se entende pessoas comuns, "significa você e eu. Para sermos coerentes e, assim, previsíveis para nossos filhos, devemos ser nós mesmos. Se formos nós mesmos, os nossos filhos podem passar a conhecer-nos" (WINNICOTT, 1999, p.141).

Mencionamos que faz diferença no relacionamento com o bebê, a mãe ser ela mesma. Uma continuidade no modo de ser e se relacionar com o bebê, incluindo ainda os cuidados necessários, preservando certa regularidade, previsibilidade, nada que implique muitas variações na relação com o bebê.

Veremos que autor parte de um início teórico onde o bebê não estaria integrado, assinalando a importância de um ambiente favorável que sustente o bebê em sua condição de dependência e facilite o começo das primeiras experiências de ser e as primeiras relações com objetos.

Mas, de quais condições favoráveis falamos? Que ambiente é esse? "O ambiente que a mãe fornece é primordialmente ela mesma, a sua pessoa, a sua natureza, as suas características distintas que a ajudam a saber que é ela mesma" (WINNICOTT, 1999, p.143-144).

Assim, o ambiente inicial é a mãe. A mãe como pessoa e seu modo de ser e se relacionar com o bebê. Isso inclui ainda, o pai do bebê, outros filhos do casal, os avós, tias e tios, ou seja, a família, com suas especificidades e suas relações. O que o bebê irá descobrindo aos poucos, com o tempo...

"Esclarece-se que o conceito de ambiente se refere não apenas às pessoas de relacionamento do bebê, como a mãe, o pai ou outros cuidadores, mas incluem-se no ambiente todos os cuidados dispensados ao bebê no atendimento de suas necessidades", conforme apresentamos nos cuidados de holding e handling (MORATTI; LIMA, 2014, p.227).

Contemplado por modos de ser e de se relacionar da mãe com o bebê, parece estar o fato importante que a mãe sente que o seu bebê é uma pessoa, ela olha para ele como pessoa e sente que ele é digno de ser conhecido como tal, e conhecido o mais cedo possível. O interesse da mãe em conhecer seu bebê é expresso pelo contato entre ela e o bebê, coisas simples como 
o toque, o olhar, o segurar, o abraçar, a presença de voz e de fala, a paciência, o pensar sobre o bebê e suas necessidades estão envolvidas no contato.

Estamos abordando coisas que não podem ser ensinadas à uma mãe e que nascem de uma relação de intimidade entre ela e o bebê. "Elas dependem inteiramente do cuidado e da compreensão humanas e de uma coleção de coisas que podem ser reunidas e descritas através da palavra 'amor" (WINNICOTT, 1994, p. 430).

Por amor, o autor não se refere ao sentimentalismo, por amor entende algo que se assemelha a uma força primitiva, que reuniria o instinto de posse, o apetite e momentos de contrariedade, com alterações de humor, ou seja, raiva, ódio, cansaço, mas também, aponta a generosidade, a energia e humildade. Aspectos que constituem a mãe como pessoa.

Lejarraga (2012) diz que o sentimentalismo na visão de Winnicott seria a negação do ódio e da ambivalência constituintes do universo materno. E que o termo "amor" é usado pelo autor para expressar as condições de cuidados maternos, os cuidados que ele chama de suficientemente bons.

A primeira vista, afirmar que uma mãe pode odiar seu filho pode parecer espantoso, talvez, incompreensível? Nem tanto! Vejamos.

Se pensarmos na variedade de situações e experiências que uma mãe tem com seu filho, logo se começa a considerar essa afirmação. Durante os cuidados, principalmente, a amamentação, o bebê morde a mãe, pode machucar seu seio, altera toda a sua vida, especialmente sua rotina e atividades. $\mathrm{O}$ bebê é impiedoso, pode chorar exaustivamente, pode não dormir, pode querer colo continuamente, solicitar atenção e uma série de outros motivos pelos quais, os efeitos sobre a mãe podem tornar-se perturbadores, cansativos, podendo gerar muita irritação.

Apesar disso, a mãe continua cuidando do bebê e não desconta nele seu ódio, ao invés de vingar-se dele, ela tolera! A dedicação ao filho continua...

Então, amor nesse sentido, também pode ser entendido como cuidados suficientemente bons, como resultado de uma adaptação do ambiente as necessidades do bebê. Assim, desmanchando a idealização do amor materno, o amor trata-se da dedicação materna, que fundamentalmente é identificação.

Winnicott em seu trabalho clínico observou mães com seus filhos e descreveu muitas situações, através das quais, se pode conhecer elementos constituintes dessa relação que 
indicam o desenvolvimento dos bebês. Citaremos uma passagem longa, em que ele escreve às mães, mas que nos parece exemplar do que estamos tentando mostrar.

\begin{abstract}
Você já conhece o seu filhinho porque o observa enquanto ele está deitado em seu colo, ou permite-lhe que brinque em seus braços, ou em seus seios, você poderá ver a excitação nas proporções adequadas e reconhecer nisso uma forma de amor. Você estará também apta a compreender o que sucede quando ele afasta a cabeça e recusa a beber, à semelhança do cavalo do provérbio quando o levaram para água, ou quando fica adormecido em seus braços em lugar de prosseguir chupando, ou quando fica tão agitado que não consegue executar bem seu trabalho. Está apenas assustado com o que sente e você poderá ajudá-lo, nessa ocasião, como nenhuma outra pessoa o faria, graças à sua grande paciência, permitindo-lhe que brinque um pouco, que abocanhe $o$ mamilo ou que o agarre até em suas mãos; enfim, qualquer coisa que permita ao bebê um pouco de prazer, até que por fim ganhe confiança para correr o risco e chupar. Isto não é tarefa fácil para você, pois você tem que pensar também em si própria, com seus seios excessivamente cheios ou, então, esperando que o bebê mame, antes que comecem a encher. Mas se você sabe o que está acontecendo, encontrará maneira de superar os momentos difíceis e fazer o bebê estabelecer boas relações consigo enquanto se alimenta (WINNICOTT, 1971, p.24).
\end{abstract}

Observa-se que a mãe conhece e compreende o bebê, ela permite que algo que está acontecendo com o ele se prolongue no tempo, ela sustenta a situação no tempo e o mantém em seus braços (o espaço). Ela espera e, com paciência, facilita brincadeiras em seu próprio corpo, enquanto o bebê lida com a tensão instintual e, ela o ajuda, ampara o bebê diante do desconhecido, acolhe seu susto. A mãe experimenta sua própria instintualidade junto com o bebê. $\mathrm{O}$ corpo da mãe e o corpo do bebê em contato. Isso dura até que o bebê faça novamente o gesto, retorne à ação. Essa é a tarefa da mãe, é trabalhosa para ela, mas ela se mantém, ela permite que assim aconteça, porque ela sabe que o bebê precisa, ela sabe que ele precisa dela assim, desse modo, por isso ela apoia e sustenta o bebê. Winnicott apontava como essa experiência envolve o corpo e a satisfação da própria mãe com o bebê em diversas situações de cuidados, vejamos:

Prefiro que vocês usem a imaginação, mas é importante chamar a atenção para o fato de que, qualquer que seja o modo de alimentar o bebê, e por mais satisfatório que possa ser, a satisfação da mulher capaz de usar uma parte de seu corpo desta forma é algo totalmente diferente (WINNICOTT, 2006, p. 25).

É preciso dizer, que há prazer envolvido, a mãe também experimenta satisfação nessa relação, isso confere vitalidade e sentido à relação, o bebê também precisa experimentar uma 
mãe viva, intensa, do contrário, a satisfação do bebê não pode ser completa, pois cairá na monotonia e na falta de sentido para ele.

\begin{abstract}
O bebê não quer tanto que lhe dêem a alimentação correta na hora exata como, sobretudo, ser alimentado por alguém que ama alimentar seu próprio bebê. $\mathrm{O}$ bebê aceita como coisas naturais a maciez das roupas ou a temperatura correta da água do banho. O que ele não pode dispensar é o prazer da mãe que acompanha o ato de vestir ou de dar banho ao seu próprio bebê. O prazer da mãe tem de estar presente nesses atos ou então tudo o que fizer é monótono, inútil e mecânico (WINNICOTT, 1971, P.28).
\end{abstract}

Como já dissemos anteriormente, é preciso que se atenda a necessidade, mas indo ao encontro do que é necessário. Nesse caso, pode-se pensar que o bebê precisa ser amamentado, isso é uma necessidade, porém, ser apenas amamentado, não confere satisfação a outra necessidade, ou seja, a necessidade de experimentar a realidade do gesto que o bebê faz, a realidade da relação com a mãe. Experimentar ser amado e amar. "Portanto, ao examinarmos a experiência de amamentação de um bebê, a primeira coisa a fazer é pensar em termos da riqueza da experiência e do envolvimento total da personalidade" (WINNICOTT, 2006, p. 24).

Estamos tentando esclarecer que o autor chama a nossa atenção para o fato de que as necessidades do bebê não se restringem apenas aos instintos, embora considere que eles sejam importantes. Ele dirige o olhar para outros elementos que compõe o desenvolvimento do ego e suas necessidades.

Winnicott quando se refere ao cuidado materno, nos primeiros meses de vida do bebê, faz uma diferenciação entre a mãe como ambiente e a mãe como objeto. A mãe ambiente é aquela que oferece os cuidados necessários, se ocupando em manter o ambiente do bebê o mais contínuo e confiável quanto possível. Enquanto a mãe-objeto é a mãe dos momentos de relacionamento excitados do bebê, é a mãe a quem o bebê dirige seus impulsos amorosos e destrutivos (DIAS, 2003).

Isso também mostra que os modos de relação se alternam no bebê, pois ele se relaciona diferentemente com a mesma mãe, nos momentos de excitação e nos momentos de tranquilidade, o que contribuirá no processo de diferenciação entre o bebê e mãe.

Dessa forma, a importância do relacionamento da mãe como ambiente para o bebê, especialmente sob a forma de cuidados, mostra a capacidade de identificação da mãe com a fragilidade e o desamparo de seu bebê, fazem com que ela reconheça e acolha a condição de 
dependência do bebê. Assim, ela é capaz de dedicar-se, por um período a esses cuidados e proteger o bebê de situações que ele ainda não é capaz de viver, ao mesmo tempo, que atende às necessidades e o capacita a viver.

\subsubsection{O bebê na perspectiva winnicottiana}

Chegamos ao momento de falar sobre o bebê e seu processo de desenvolvimento que viemos abordando em nosso texto da perspectiva materna, sua identificação, os cuidados como holding e handling que constituem o ambiente que é a mãe para o bebê.

O que é um bebê? Nosso autor responderia "isso que chamam de bebê não existe"! ${ }^{10}$

Para Winnicott, na origem o que existe é um conjunto anatômico e fisiológico e somado à este uma disposição para o surgimento de uma personalidade humana. Haveria uma tendência para o crescimento físico e biológico e uma tendência ao desenvolvimento da porção psíquica da integração psicossomática. Sintetizando, "o complexo a que damos o nome de bebê é a sua experiência cumulativa de vida" (WINNICOTT, 2006, p.80).

A ideia é de que a base do desenvolvimento psíquico humano se assenta na continuidade da linha da vida. Por continuidade, quer dizer tudo aquilo que faz parte da experiência de vida de uma pessoa se mantém ou jamais poderia vir a se perder, apesar de acontecimentos complexos e diversos transformarem, como de fato acontece, esses acontecimentos em algo inalcançável à consciência.

Winnicott diria que o bebê "é um fenômeno complexo que inclui o seu potencial e mais o seu meio ambiente" (WINNICOTT, 1994, p.196). O que quer dizer?

No princípio, não há um bebê, ou melhor, não é possível falar em um bebê sem falar na mãe ou nas pessoas que cuidam dele. "Um bebê não pode existir sozinho, sendo essencialmente parte de uma relação" (WINNICOTT, 1971, p.99). O bebê, como uma pessoa, como um, ainda não existe, pois no começo não há diferenciação entre o bebê e a mãe, pode-se dizer que o bebê é com a mãe.

${ }^{10}$ (WINNICOTT, 2000, p.165). 
...é impossível descrever um bebê ou uma criança pequena sem que se inclua uma descrição dos cuidados que ela recebe, e que só gradualmente vão se transformar em algo separado do indivíduo. Em outras palavras, os processos de maturação, facilitados de uma forma extremamente complexa pelos seres humanos que cuidam do bebê, terminam por fazer com que a criança repudie o que é o $n \tilde{a} o-E U$, vindo a construir o $E U$ (WINNICOTT, 2006, p.47).

Winnicott ao falar do bebê, descreve uma dupla mãe-bebê, primeiro, dois em um e, posteriormente, um mais um! Ou, seria melhor dizer, um mais dois?

O bebê que depende da mãe é muito imaturo, ou seja, não se constituiu como alguém que se entende como uma pessoa, ainda não é uma pessoa que se diferenciou como tal, que já pode dizer-se em primeira pessoa do singular: EU! O bebê, em sua imaturidade, é cuidado para que alcance o status de independência, para que ao longo dessa relação de cuidados, possa formar sua subjetividade, sua existência pessoal.

Para que o estabelecimento de um Eu, melhor dizendo, para que um processo de diferenciação Eu e Não-Eu, possa se desenvolver e constituir um indivíduo, o bebê precisa contar com os cuidados de alguém.

Note-se que o autor fala em processos, o que nos faz pensar que algo precisa ocorrer ao longo do tempo, aos poucos, gradativamente. Assim, o bebê vai alcançando a diferenciação, ele adquire o conhecimento de sua existência e a existência de outros, vai sabendo o que é ele e o que é a mãe, o pai e o mundo.

O bebê vai acumulando experiências de ser ao longo do tempo, em uma linha contínua de vida que se tece por cuidados maternos facilitadores do amadurecimento. Nesse começo, o que o bebê consegue conhecer da mãe são os cuidados que ele recebe e pequenos detalhes do corpo materno, como os mamilos, o calor do corpo, o sorriso, os cheiros.

O que se vê, é a mãe compartilhando com o filho fragmentos do mundo, pequenas amostras para alguém muito pequeno, o que vai se ampliando devagar, acompanhando a crescente capacidade do bebê para conhecer o mundo.

Podemos dizer que "ao introduzir o mundo à criança em pequenas doses, isto é, na adaptação às necessidades de ego de seu bebê, a mãe concede tempo para o desenvolvimento das ampliações dos poderes do bebê que chegam com o amadurecimento" (WINNICOTT, 1994, p. 60).

Estamos tratando, então, da adaptação às necessidades dele. Mas, afinal, o que são as necessidades de um bebê? 
As necessidades estão relacionadas ao corpo e aos cuidados realizados em sua função, que podem ir além dos cuidados físicos. Vejamos!

Talvez, ao falar sobre as necessidades do bebê, uma das primeiras ideias que poderão surgir dizem respeito à alimentação. Winnicott chama atenção para o fato de que nem todas as mães conseguem amamentar seus bebês e nem todos os bebês se deixam alimentar ao seio. Pode ser ocasião de uso de mamadeiras para facilitar a alimentação do bebê.

A prioridade recai sobre os aspectos relacionados ao ato de alimentar um bebê, como o contato e a experiência que se tornam enriquecedoras à integração da personalidade do bebê.

Acrescenta-se que "um bebê não começa, necessariamente, querendo uma alimentação regular e a horas certas; de fato, creio que o que um bebê espera é encontrar um seio que aparece quando é procurado e desaparece quando já não é preciso” (WINNICOTT, 1971, p. 23).

A necessidade aqui não está ainda no alimento ou na satisfação, mas sim, está em ao lançar-se em busca (mesmo sem saber o que), encontrar algo a partir do qual criar e depois simplesmente dispensar quando já não é necessário. Inicialmente, essa experiência é uma necessidade, o que pode significar, também, não ser alimentado quando ele não está pronto para tal.

Para que essa experiência ocorra, é preciso que a mãe e o bebê compartilhem da presença um do outro, que a partir do convívio e dos cuidados a mãe possa conhecer seu bebê e se apresentar a ele, oferecendo tempo para que ele se dirija em busca de algo. Isso leva ao apontamento de que

\footnotetext{
a relação do bebê com a mãe, durante a orgia da amamentação, é particularmente intensa. Essa relação também é complexa, pois tem de incluir a excitação da expectativa, a experiência da atividade durante a amamentação, bem como a sensação de gratificação, com o repouso ou acalmia da tensão instintiva resultante da satisfação (WINNICOTT, 1971, p.56-57).
}

Vê-se que a situação de amamentação envolve mãe e bebê em uma relação que tem origem na simplicidade que é alimentar o bebê quando há fome e, que se amplia e se intensifica à medida que observam-se outros elementos em jogo nesse cuidado.

Então, qual o valor positivo da amamentação? 
...o bebê está vivo e desperto, e toda a sua personalidade em formação está envolvida no processo. Grande parte da vida de vigília do bebê está voltada para a alimentação. De certa forma, o bebê está acumulando material para o sonho, embora logo se manifestem todas as outras coisas que também passam a fazer parte do processo, e que podem refletir-se na realidade interior da criança adormecida, que naturalmente está sonhando (WINNICOTT, 2006, p. 24).

Ao alimentar o bebê a mãe está alicerçando as bases para a relação humana. O bebê está se desdobrando em experiências que o tornarão quem ele é! Dessa forma, a amamentação propicia ao bebê o encontro com o corpo da mãe (seio), o seu próprio corpo e com ele todas as excitações e tensões instintivas e o subsequente retorno ao estado de quietude e repouso. Com isso, há um enriquecimento da experiência do bebê que em repouso irá elaborar as experiências vividas e, aos poucos armazenar e transformar em referências de si e da relação com outros humanos.

Os bebês dependem e precisam de contato com outras pessoas e a forma inicial de contato se traduz pela relação corporal entre a mãe e o bebê. A mãe pega o bebê ao colo para amamentá-lo, talvez, seja preciso que ela pegue ao colo para consolar o choro ou para mudá-lo de posição no berço ou no carrinho, afim de que não tenha dores no corpo ao permanecer por tempo prolongado na mesma posição. Quem sabe, o bebê precise de mais ou menos roupas para regular a temperatura do corpo, talvez tenha dores ou cólicas.

Muitas são as situações que estão em jogo nas necessidades corporais, mas há ainda aquelas que se referem "as perturbações mais grosseiras", ou seja, o bebê deve ser preservado de situações que gerem mudanças bruscas, como, por exemplo, ser erguido abruptamente do berço durante o sono, ter seus olhos expostos à luz direta do sol (WINNICOTT, 2006, p. 75).

O autor segue descrevendo outros tipos de necessidades muito sutis que são aquelas ligadas ao contato com o corpo da mãe, como o calor do corpo, o envolvimento do bebê com o ritmo da respiração e batimentos cardíacos da mãe, os cheiros dos pais, o som da voz, cores, enfim, aspectos que compõe a vivacidade do ambiente que circunda o bebê. Essas experiências ocupam o tempo e o espaço do bebê, de modo que ele não seja deixado sozinho, enquanto não há condições para tal.

Dethiville (2011) complementa esse ponto de vista, ao dizer que acolher as necessidades dos bebês não é o bastante para promover a satisfação psíquica necessária para o advir de uma pessoa. Indica que o importante é ir ao encontro daquilo que é a necessidade, sendo, nesse sentido, indispensável atender ao que é necessário. 
Como estamos vendo, o atendimento as necessidades do bebê nos primeiros meses de vida são fundamentais para dar origem as primeiras experiências de ser do bebê, para a partir destas experiências cumulativas, o bebê possa integrar sua personalidade e alcançar existência pessoal.

\subsubsection{Os três pilares: as tarefas do amadurecimento}

Passaremos à descrição das tarefas pelas quais o bebê integrará sua personalidade e alcançará o sentido de realidade, bem como a elaboração da existência psíquica e corporal. A integração em um Eu!

Para que seja possível compreender como ocorre esse processo de diferenciação do bebê em um Eu e um Não-Eu, faz-se necessário conhecer os elementos constituintes do processo de amadurecimento do bebê.

Winnicott ao descrever os bebês diz:

\footnotetext{
Cada bebê é uma organização em marcha. Em cada bebê há uma centelha vital, e seu ímpeto para a vida, para o crescimento e o desenvolvimento é uma parcela do próprio bebê, algo que é inato na criança e que é impelido para a frente de um modo que não temos que compreender (WINNICOTT, 1971, p. 29).
}

Essa passagem refere-se a um dos escritos da fase inicial de construção do pensamento de Winnicott sobre o amadurecimento. No entanto, o que já se evidencia é o modo de pensar o desenvolvimento humano como um processo que caminha em direção a ampliação, a expansão do bebê em direção à vida, ao mundo, entendendo que há, no bebê, um impulso em direção à vida.

O desenvolvimento humano, para Winnicott, constitui-se a partir de três tarefas básicas a serem vivenciadas na relação do bebê com a mãe e o ambiente. Estas tarefas se referem à conquista da integração do eu no tempo e no espaço, o alojamento da psique no corpo (personalização) e as relações objetais (realização) (WINNICOTT, 2006). 
Mostraremos como Winnicott entende o entrelaçamento com o tempo e como é possível para o bebê conquistar o desenvolvimento psíquico pessoal. Nesse ponto, dois fatores são evidenciados no processo de desenvolvimento do bebê: uma tendência inata à integração e a continuidade de um ambiente facilitador no decorrer do tempo (DIAS, 2003).

$\mathrm{Na}$ concepção de Winnicott, todo ser humano é dotado de uma tendência inata a integração e, é um ser temporal. Isto significa dizer, que o homem vai se constituindo a partir da integração de várias experiências humanas ao longo do tempo, o indivíduo vai sendo no tempo.

Destaca-se como importante no pensamento do autor que tempo e espaço apresentamse em contínua inter-relação, além disso, essas aquisições não são impostas ao bebê, elas são facilitadas pelo ambiente que aguarda o ritmo do bebê. Assim, o sentido inicial de tempo se associa a continuidade da vida, a continuidade de ser, sendo o tempo contado mais pela respiração da mãe, as alterações entre movimento e quietude, algo já anunciado para o bebê na vida intrauterina.

Portanto, o primeiro sentido de tempo considerado é o tempo subjetivo, pois diz respeito ao aspecto do mundo subjetivo do bebê e se liga a continuidade da presença e dos cuidados maternos. "O bebê não sabe da existência permanente da mãe, mas sente os efeitos da presença e, vagarosamente, criando uma memória dessa presença, conta com isso" (DIAS, 2003, p.197).

Esse é um ponto importante, o sentido de continuidade que o bebê experimenta se traduz na possibilidade de saúde, considerando a quebra dessa continuidade potencialmente prejudicial ao bebê. E, a ruptura da continuidade está relacionada a continuidade da presença e cuidados da mãe, assim, "se a memória da presença se apaga, a sensação é de aniquilamento, de loucura" (DIAS, 2003, p.198).

Loucura nesse contexto "significa simplesmente uma ruptura do que possa configurar, na ocasião, uma continuidade pessoal de existência” (WINNICOTT, 1975, p.136).

A aquisição do sentido de espaço pelo bebê está ligada ao sentimento de ter um lugar, primeiramente um lugar em que se possa habitar. Habitar o corpo é o primeiro sentido de espacialização para o bebê, o que se ampliará ao sentido de ter um lugar no mundo. Retomaremos esse ponto mais à frente...

Feitas essas primeiras considerações, chega-se a compreensão de que a teoria do amadurecimento pessoal é a explicitação temporal, na forma de estágios ou etapas, das várias 
tarefas que a tendência inata ao amadurecimento impõe ao indivíduo ao longo da vida (DIAS, 2003, p. 94).

Assim, por possuir uma tendência inata a integração, desde que o bebê nasce e, a partir do contato com a mãe, principalmente dos seus cuidados, o bebê faz experiências de ser. Experiências que ao se repetirem durante o tempo e com regularidade, podem se integrar para que o bebê alcance o status unitário. A integração da experiência de ser e continuar a ser levam a criança a se constituir como uma pessoa inteira.

Esclarecemos que, de acordo com o momento do amadurecimento, o termo experiência apresenta uma variação de sentido no pensamento de Winnicott. Quando o termo é usado para tratar dos momentos inicias de vida do bebê, experiência está se referindo "a possibilidade de habitar, durante o tempo necessário, num mundo subjetivo, que é regido pela ilusão de onipotência" (DIAS, 2003, p.123).

Outro sentido de experiência trazido, diz respeito ao período em que o bebê está se integrando temporal e espacialmente e habitando seu corpo, ou seja, quando algum alcance de um sentido de unidade e realidade se apresentam.

Observe-se que o ambiente é o aspecto facilitador, como se ele operasse como ponte entre o bebê e o mundo, o elo e a transição de modos de relacionamento do bebê consigo mesmo e com o mundo. Nessa linha, Winnicott coloca:

De tudo o que constatamos, a questão que mais nos interessa aqui é aquela parte do processo a que chamamos integração. Antes da integração, o indivíduo é um conjunto não-organizado de fenômenos sensório-motores contidos pelo ambiente externo. Depois da integração o indivíduo É, ou seja, a criança humana atingiu o status de unidade, podendo já dizer EU SOU (a não ser pelo fato de não ser ainda capaz de falar). O indivíduo possui agora uma membrana limitante, de forma que o que é nãoeu é repudiado, é externo. Este eu possui agora um dentro, onde podem reunir-se as memórias de experiências e edificar-se a estrutura infinitamente complexa que pertence ao ser humano (WINNICOTT, 2005, p. 216).

Dias nos coloca que o termo tendência inata à integração se refere a integração do ser humano em uma unidade, o que significaria dizer, "unificar-se e responder por um eu" (DIAS, 2003, p.94).

A ideia da integração visa a mostrar como o bebê precisa integrar-se em uma unidade, como uma pessoa diferenciada e também inteira, o que implica estar em contato com a instintualidade e com um sentido de realidade. 
Esclarecendo um pouco mais, vamos pensar o momento anterior a integração, qual seja? A não-integração. Essa diz respeito a como o bebê está espalhado, não reunido, o bebê inicialmente é inarticulado, composto por partes e sensações advindas do corpo.

Nesse sentido, não-integração "significa falta de reunião num si-mesmo, falta de integração no espaço e no tempo, falta de integração psicossomática, enfim, falta de inteireza (wholeness)" (DIAS, 2003, p.128).

Para que se compreenda a interface dessas tarefas que compõe o amadurecimento do bebê facilitadas pela adaptação e cuidados maternos é necessário partir de coisas simples. Ao tratar dessas tarefas estaremos nos remetendo em muitos momentos ao corpo.

A maior parte do tempo, consideramos a nossa existência no corpo e nossa referência à ele como dado, nos acostumamos a falar sobre o corpo como sendo nós mesmos e como imagem de quem somos, como o Eu. Considera-se que "a localização do eu no próprio corpo é muitas vezes tida como óbvia" (WINNICOTT, 2000, p.223).

Mas, como chegamos a isso?

Nem sempre foi assim, percorremos um longo caminho para que o sentido do corpo se realizasse, pois esse modo de relacionar-se com outros e consigo mesmo como alguém uno e que possui e é a partir do corpo é uma conquista!

\footnotetext{
Na vida normal do bebê ocorrem longos períodos de tempo nos quais o bebê não se importa em ser uma porção de pedacinhos ou um único ser, nem se ele vive no rosto da mãe ou em seu próprio corpo, desde que de tempos em tempos ele se torne uno e sinta alguma coisa (WINNICOTT, 2000, p.224).
}

Vê-se que a partir desse contato com a mãe, que segura ao colo, ajeita em seus braços e reúne o corpo do bebê em todas as suas partes e faz isso, sempre olhando para o filho, falando com ele, embalando ou acariciando, há momentos que o bebê pode sentir-se um, pode experimentar a integração e, depois retornar a não-integração.

Observa-se que há uma alternância entre as sensações que pode experimentar o bebê, ora sendo integrado, ora sendo não-integrado. 
pelo nome, e também por agudas experiências instintivas que tendem a aglutinar a personalidade a partir de dentro (WINNICOTT, 2000, p.224).

A instintualidade que está envolvida nas experiências inicias do bebê que, além de serem acolhidas e satisfeitas, são integradas ao mesmo passo que atuam de forma integradora.

Vamos delinear o que Winnicott entende por instinto, para que seja possível traçar os caminhos pelos quais podem ser integrados pelo bebê e os desdobramentos da integração rumo ao amadurecimento.

Winnicott (1990) denomina de instinto, intensas forças biológicas, ou melhor, impulsos que se apresentam e se ausentam na vida humana e que exigem uma ação. Os momentos de excitação do instinto geram, na criança, uma preparação para satisfazer o impulso quando suas exigências atingem níveis elevados.

Se a satisfação é encontrada no momento culminante da exigência, surge a recompensa do prazer e também o alívio temporário do instinto. A satisfação incompleta ou mal sincronizada acarreta alívio incompleto, desconforto, e a ausência de um período de descanso muito necessário entre as duas ondas de exigências (WINNICOTT, 1990, p. 57).

Winnicott não se mostrou preocupado em diferenciar os tipos de exigências instintivas, nem procurar pela classificação dos instintos ou mesmo, dizer se há um único instinto ou mais de um, estas questões não adquiriram muita relevância em seu pensamento. Ele dizia que "com o termo instintivo quer se significar o que Freud chamou sexual, isto é, o conjunto de excitações locais e gerais que são um aspecto da vida animal; na experiência destas há um período de preparação, um ato com um clímax, e um pós-clímax" (WINNICOTT, 1983, p.119).

Contudo, ponderava que faz diferença considerar as funções corporais envolvidas, pois a excitação pode ser geral ou local. Há diferenças entre elas, sendo que a excitação generalizada contribui para que o bebê se sinta um ser total, pois todo seu corpo pode estar envolvido pela excitação instintual, ou ainda, pode indicar alguma nova integração no desenvolvimento. Enquanto, a excitação local pode indicar a elaboração imaginativa de partes do corpo, "uma espécie de clímax pode ser atingido em qualquer lugar, mas em geral ele ocorre em regiões específicas" (WINNICOTT, 1990, p.58).

Acrescenta-se que a instintualidade é o terreno sobre o qual de se desenvolverá a sexualidade, aspecto importante do processo de amadurecimento. A instintualidade inicial da 
vida constitui as raízes da sexualidade e, vê-se ligada a elas, uma destrutividade inicial que constitui uma das raízes da agressividade (DIAS, 2003).

Nesse ponto, foram lançadas as bases para falarmos em estados excitados e tranquilos do bebê. Esses estados se alternam constantemente e a transição de um estado para o outro é algo a ser auxiliado pelos cuidados maternos.

Os estados excitados possuem duas origens: a instintualidade e a motilidade. Eles surgem de "um impulso, apoiado, quase sempre, na crista de uma onda instintual. Desenvolvese uma tensão que, rapidamente, se transforma numa urgência; nela toma carona o impulso motor" (DIAS, 2003, p.174).

Acontece que o bebê é tomado por esse estado, o corpo do bebê é tomado por algo que ele não sabe o que é, pois o bebê ainda não sabe a cerca de suas necessidades, nem mesmo a sabe sobre si ou sobre a existência de objetos, mas o bebê se dirige a algo em algum lugar. Nota-se que a "ação exigida pelo impulso instintual é, no início, apenas um gesto, que não tem meta certa, nem incide sobre um objeto em particular" (DIAS, 2003, p.176).

Com relação à motilidade, observa-se a sua presença já na vida intrauterina, onde o feto em desenvolvimento realiza movimentos que o colocam em contato com as paredes do útero materno, ocasião que o bebê se sente envolvido por todos os lados e também pode experimentar oposição, como exemplo os chamados “chutes" pelas gestantes. Ao nascer, a movimentação do bebê continua e a criança se depara com objetos e com o próprio corpo da mãe. Aos poucos, por repetição e regularidade, o bebê vai ganhando experiências de constância, permanência, consistência etc. Aliado a isso, se houver facilitação ambiental, a motilidade poderá fundir-se à tensão instintual, o que dará sentido de realidade ao impulso e, mais tarde, formará uma das raízes da agressividade.

Antes da integração da personalidade, já lá está a agressividade. O bebê dá pontapés dentro do útero: não se pode dizer que ele esteja abrindo o caminho para fora a pontapés. Um bebê de poucas semanas agita os braços: não se pode dizer que ele esteja querendo golpear. $\mathrm{O}$ bebê mastiga os mamilos com suas gengivas: não se pode dizer que ele esteja pretendendo destruir ou machucar. Em suas origens, a agressividade é quase sinônimo de atividade: trata-se de uma função parcial (WINNICOTT. 2000, p.289). 
Observa-se que antes da integração, a agressividade é entendida como motilidade, se relaciona a toda atividade corpórea do bebê que ainda não adquiriu intenção, por isso é considerada também parcial, ainda precisa avançar para se constituir como agressividade em si.

Nesse período inicial, a agressividade está vinculada a expressão primitiva de amor. Aqui, Winnicott mistura a agressividade e impulso amoroso para mostrar como inicialmente essa agressividade que é ligada à motilidade, poderá se transformar em agressividade propriamente dita com propósito e intenção.

O autor coloca "que os impulsos do amor primitivo (id) têm um aspecto destrutivo, embora não haja na criança a intenção de destruir, visto que o impulso pertence a uma etapa anterior ao concernimento" (WINNICOTT, 2000, p.296).

Com isso, ele quer dizer que em um momento posterior do desenvolvimento, quando a integração já estiver em curso, o bebê poderá perceber que seu impulso amoroso, é ao mesmo tempo destrutivo e pode causar danos à mãe, assim poderá começar a vir a se preocupar, o que na dependência absoluta ainda não ocorre.

Destaca-se, ainda, que a agressividade é importante no processo de integração, fundamentalmente é ela que confere o sentido de realidade ao gesto do bebê. Assim, "a sensação de realidade advém principalmente da raiz motora (e sensorial que lhe corresponde), e as experiências eróticas com uma fraca participação do elemento motilidade não fortalecem a sensação de realidade ou de existir” (WINNICOTT, 2000, p.299).

Como estamos vendo, uma importante parcela da motilidade entendida como impulso destrutivo funde-se ao impulso amoroso, pois a "motricidade é indissociável do impulso amoroso primitivo, já que o bebê só pode ir ao encontro da mãe para obter satisfação através da atividade ou movimentação" (LEJARRAGA, 2012, p. 49).

No entanto, parte do impulso amoroso ou motilidade não fundida ficará disponível para outros destinos. E esta motilidade que permanece livre precisa encontrar a oposição ou algo para empurrar, isto porque, ao encontrar algo a que se opor a vitalidade do bebê (motilidade) origina seu potencial agressivo, que também pode ser experimentando como real.

Com isso, "a motilidade, quando topa com o ambiente que faz oposição, possibilita o reconhecimento paulatino do mundo externo, constituindo a porta de entrada, num longo e precário caminho, para a alteridade” (LEJARRAGA, 2012, p. 50). 
Essas são as bases para os primeiros relacionamentos excitados entre o bebê e a mãe. Esses momentos excitados se desenvolvem contra um fundo de tranquilidade, no qual outro tipo de relacionamento se forma entre a dupla.

Os estados tranquilos são caracterizados no bebê por momentos não-integrados, um estado de relaxamento. O bebê pode ficar entregue ao descanso, a quietude, certo tipo de solidão, entregue a divagação, uma espécie de não contato com a mãe. Esses estados possibilitam ao bebê realizar um tipo de elaboração das experiências tanto corpóreas como de contato com a mãe e com aspectos do ambiente (DIAS, 2003).

Lejarraga acrescenta que nesses estados tranquilos o bebê pode além de ficar nãointegrado, “estar num estado em que não há orientação, de ser capaz de existir por um momento sem ser nem alguém que reage às contingências externas nem uma pessoa ativa com uma direção de interesse ou movimento" (LEJARRAGA, 2012, p.39).

Os estados tranquilos são também aqueles que proporcionam a distinção entre o que se poderá chamar de mundo do bebê e mundo dos objetos. Além disso, os estados tranquilos é que atribuem a realidade ao gesto apoiado na tensão instintual, pois o impulso nasce desse estado de relaxamento, de não-integração. Verifica-se que "é somente a partir do estado de descanso que um impulso qualquer pode ser sentido como real e pode tornar-se, verdadeiramente, uma experiência pessoal” (DIAS, 2003, p.191).

Nota-se, assim, que os momentos de não-integração participam da consolidação das experiências instintuais e atribuem realidade ao gesto iniciado pelo bebê.

Todo esse percurso para mostrar como a tendência a integração se relaciona com vários elementos em curso durante o amadurecimento, sustentada pelos cuidados maternos ou ambiente. Desta forma, tentamos mostrar como os estados excitados e tranquilos são movimentos importantes para a integração do eu e a personalização.

Pretendeu-se, com o termo "personalização", chamar a atenção para o fato de que a morada desta outra parte da personalidade no corpo, e um vínculo firme entre o quer que se ache lá e que chamamos de psique, em termos desenvolvimentais representa uma conquista da saúde (WINNICOTT, 1994, p.203).

Personalização se refere ao alojamento da psique no corpo, ou melhor, a aquisição do sentido de corpo, do corpo como morada. Assim, "a integração psicossomática, que também pode ser entendida como a conquista de uma moradia da psique no soma, deve ser seguida pela 
fruição de uma unidade psicossomática na experiência de estar vivo no mundo" (JUNIOR, 2008, p.946).

O estabelecimento do alojamento da psique no corpo constitui um importante aspecto para a conquista da saúde. Ao alcançar a personalização, o bebê é capaz de viver momentos de não-integração, de relaxar e entregar-se a momentos de não exigência de existir e continuar existindo todo tempo (MORATTI; LIMA, 2014).

Verifica-se então que a espacialização do bebê se insere como aspecto importante e relaciona-se diretamente a integração do corpo como espaço, um lugar onde morar. "Durante todo o tempo em que a coesão psicossomática está em via de realização, os braços da mãe e o corpo do bebê são uma e a mesma coisa, de modo que se pode dizer que a primeira morada do bebê é o próprio corpo do lactente no colo da mãe” (DIAS, 2003, p. 209).

Destacamos, então, que o sentido de tempo é tecido ao mesmo passo que o sentido de espaço, tendo em vista que são construídos na experiência do bebê e seu corpo junto ao corpo da mãe. Vemos o bebê sustentado pelos braços e o olhar materno, o bebê sendo, no tempo e no espaço, tecendo suas primeiras experiências de contato com o ambiente.

As experiências com o espaço se relacionam com a ideia de lugar, mais especificamente sobre um lugar para habitar, diz respeito ao sentir-se em casa. Habitar é um sentido que se constrói e, pode adquirir diversas formas, mas, um dos primeiros sentidos de habitar que o bebê precisa é: morar no próprio corpo, habitar o corpo. Estabelecer a "morada da psique no corpo" (DIAS, 2003, p. 205).

Ao tratarmos do alojamento da psique no corpo, parece interessante observar que psique "significa elaboração imaginária (imaginative) dos elementos, sentimentos e funções somáticas, ou seja, da vitalidade física" (WINNICOTT, 2000, p.333).

Parece que o entendimento do autor sobre esse termo implica a elaboração das experiências do bebê em seu corpo vivo, em suas necessidades e seus movimentos.

O corpo elaborado imaginativamente é o corpo vivo de alguém que respira, se move, busca algo, mama, esperneia, chupa o polegar, descansa, é acalentado, trocado, envolvido pela água do banho etc. Seja o que for que esteja sendo experienciado - e tudo no início, é experienciado no corpo e por meio do corpo - está sendo personalizado pela elaboração imaginativa. (DIAS, 2003, p.106) 
O corpo vivo do bebê, experimentando momentos excitados e tranquilos, vai aos poucos favorecendo que as experiências de sentir fome, ser alimentado, aquecido, segurado ao colo, que vivências somáticas, instintuais e de contato com a mãe sejam elaboradas de forma imaginativa pelo bebê, tornando-se as bases da psique, constituindo assim as primeiras experiências de ser do bebê. A continuidade e regularidade do toque e dos cuidados com o bebê e seu corpo possibilitam que, aos poucos, ele possa ir sabendo de si.

Nessa fase mais inicial, gradualmente, os elementos psíquicos e somáticos formam uma parceria, mostram-se envolvidos em um intercâmbio. Com o avanço do amadurecimento, “o corpo vivo, com seus limites e com um interior e um exterior, é sentido pelo indivíduo como formando o cerne do eu imaginário" (WINNICOTT, 2000, p.334).

Ao passo que a integração e a personalização estão sendo consolidadas nas experiências do bebê com a mãe e seus cuidados, havendo uma continuidade da experiência de cuidados satisfatória o bebê vai vivendo, vai sendo ao longo do tempo. Do mesmo modo, as primeiras experiências com objetos também estão em curso e em crescente desenvolvimento.

No curso normal dos acontecimentos, a mãe tenta não permitir que o bebê seja alcançado por complicações maiores que as que se encontram dentro de sua capacidade de tolerar, e trata especialmente de isolá-lo das coincidências e de outros fenômenos que estarão forçosamente fora das suas possibilidades de compreender. De modo geral, ela tenta manter o mundo tão simples quanto possível (WINNICOTT, 2000, p.335).

Significa dizer que para o surgimento das primeiras experiências de objeto, a mãe em sua relação com o bebê respeita o ritmo dele, as capacidades que ele tem para suportar as experiências, para entrar em contato com objetos, por isso, é corrente ouvir falar que a mãe apresenta o mundo ao bebê em pequenas doses, sempre aos poucos e de modo simples.

A capacidade que o bebê terá de se relacionar com objetos e usar objetos depende da forma como esses puderam ser apresentados e vivenciados pelo bebê como fundantes de um universo criativo, como parte da ilusão de terem sido criados. Considerando sob esse ponto de vista, "o quanto esse mundo criado pelo próprio indivíduo foi ou não capaz de usar objetos percebidos no mundo externo como matéria-prima" (WINNICOTT, 2000, p.228).

Para que um sentido de realidade seja alcançado e uma relação de objeto se realize é necessário, anteriormente que, a experiência de ilusão tenha sido vivida e a realidade desse mundo subjetivo se mantenha confiável. Se a ilusão pode ser bem estabelecida, aos poucos o 
bebê compreenderá que a existência do mundo é anterior à sua própria existência, ainda assim, carregará consigo o sentimento de que o mundo foi criado de forma pessoal.

\subsubsection{Os objetos e a origem das relações}

“Tornar o amor real é expulsá-lo de você para que ele possa ser de alguém..."

Com a apresentação de um ambiente suficientemente bom, ao bebê será possível lançarse ao encontro de algo em algum lugar, ainda sem saber o quê! Nesse começo, esses encontros acontecerão nos momentos de amamentação, se ampliando gradativamente, para outros momentos de cuidados.

Winnicott chamou de primeira mamada teórica a esses começos de contato do bebê com a mãe, pois acreditava que se o primeiro momento de amamentação fosse satisfatório, o contato entre o bebê e a mãe se estabeleceria e serviria de base para as demais mamadas. $\mathrm{O}$ que simplificaria a tarefa da mãe.

Ele dizia: "o bebê está pronto para criar, e a mãe torna possível para o bebê ter a ilusão de que o seio, e aquilo que o seio significa, foram criados pelo impulso originado na necessidade" (WINNICOTT, 1990, p.121).

Observa-se que o autor coloca esse movimento do ponto de vista do bebê, do ponto de vista do observador, vemos a mãe se oferecendo para ser encontrada. Ainda, sabe-se que, o que o bebê cria, não é o que a mãe ofereceu, mas por sua adaptação ativa ao bebê, a mãe oferece condições de facilitar que o bebê tenha a ilusão de criar.

Esse processo ocorre de forma silenciosa, sem que o bebê se dê conta da externalidade dos objetos. Nesse período, ele vive a experiência de criar tudo o que precisa, sem saber da existência de uma mãe que apresenta os objetos a serem criados ou encontrados.

\footnotetext{
11 Trecho da música “Quem vai dizer tchau?” de Nando Reis.
} 
Colocamos desse modo, pois parece importante considerar " [...] o paradoxo de que aquilo que o bebê cria já se encontrava ali, e que, na verdade, a coisa que o bebê cria é parte da mãe que foi encontrada" (WINNICOTT, 2006, p. 56).

Como se vê, a construção de um sentido de realidade não se dá em função da insistência da mãe quanto à natureza externa dos objetos, mas do oposto, partindo da permissão da experiência de ilusão, que no período de dependência relativa começará dar lugar a desilusão.

No entanto, até que o bebê alcance o momento para viver a desilusão e fazer um bom uso dela, a mãe mantém "a arte de dar ao bebê a ilusão de que aquilo que é criado a partir da necessidade e por meio do impulso tem existência real" (WINNICOTT, 1999, p.124).

O autor descreve esse processo como se duas linhas que viessem de direções opostas e podendo se aproximar, se colocariam superpostas, gerando um momento de ilusão.

Ressaltamos que, durante o momento da primeira mamada teórica o bebê acumula material com o qual criar. As diversas experiências de ser amamentado, somadas às impressões sensoriais e ao encontro com o objeto passam a ser memórias no bebê. E, a partir daí, é possível dizer que "aos poucos o bebê se torna capaz de alucinar o mamilo no momento em que a mãe está pronta para oferecê-lo" (WINNICOTT, 1999, p. 126).

Observa-se que a crescente capacidade do bebê facilitada pelos cuidados ambientais, possibilita o desenvolvimento de rudimentos de ego no bebê. É o que ouvimos como o ego materno favorecendo o desenvolvimento e o fortalecimento do ego do bebê. Nesse ponto, começamos a ver o desabrochar das primeiras relações de objetos, as quais facilitarão o princípio de formação do sentido de externalidade dos objetos, dito de outro modo, o início da formação do sentido de realidade.

Surgem os rudimentos de imaginação no bebê, são os alicerces da fantasia no bebê, uma vez que, "a fantasia não é algo criado pelo indivíduo a fím de lidar com as frustrações da realidade externa. [...] A fantasia é mais primária que a realidade, e o enriquecimento da fantasia com as riquezas do mundo depende da experiência da ilusão" (WINNICOTT, 2000, p.228).

Um sentido de realidade do mundo, nessa perspectiva, só é possível a partir da formação de uma realidade subjetiva, por assim dizer, essa fantasia que nasce da ilusão de criar o mundo, que se edifica no bebê e dará, então, lugar a um sentido de realidade. A aquisição do sentido de realidade externa ou compartilhada se desenvolve a partir da formação do objeto subjetivo. 
No pensamento de Winnicott, é possível identificar que as relações de objeto são tridimensionais, isto porque, há três formas de relações possíveis: as relações de objeto subjetivo, as relações de objetos transicionais e as relações de objeto objetivamente percebido ou compartilhado.

O objeto subjetivo nasce desse contato inicial com a mãe suficientemente boa que proporciona ao bebê a ilusão de onipotência, a ilusão de criar o mundo. A ilusão de onipotência é a raiz do objeto subjetivo, uma vez que objeto subjetivo é tudo aquilo que é criação do bebê, que é por ele imaginado e criado como existente a partir da necessidade.

Um bebê que está pronto para ser criativo se lança em busca de algo, em um movimento de encontro da instintualidade e vitalidade da motilidade do bebê, como um movimento impulsivo da mão ou da boca do bebê encontra o corpo materno ou o suposto objeto. "Aqui o ser humano se encontra na posição de estar criando o mundo. O motivo é a necessidade pessoal; testemunhamos então a gradual transformação da necessidade em desejo" (WINNICOTT, 1999, p. 122).

É importante frisar que só é possível falar em desejo após a criação do objeto subjetivo, pois somente a partir da constituição de uma base de subjetividade no bebê, haverá um lugar de onde experimentar o desejo como algo pessoal, como algo que parte do próprio bebê, que agora possui relações de objeto subjetivas.

Ao longo do tempo, vai se afirmando no bebê a confiança de que o objeto desejado poderá ser encontrado, isso traz a ideia de que o bebê gradualmente passa a tolerar a ausência do objeto. É o começo do reconhecimento do sentido de realidade externa. O bebê começa a ser capaz de perceber que há algo existente além dele, para além de sua criação.

Esse reconhecimento pelo bebê da realidade compartilhada como um lugar onde os objetos aparecem e desaparecem é auxiliado pela adaptação ativa da mãe que, ao favorecer o processo de ilusão e, posteriormente, pela gradual desadaptação, proporciona o processo de desilusão que auxilia na descoberta da externalidade dos objetos e da própria mãe.

Portanto, temos aqui, duas dimensões descritas, uma constituída pelo objeto subjetivo, que também pode ser chamada de mundo interno e, uma realidade objetiva, ou mundo externo. Nesse ponto, acrescenta-se a terceira dimensão, a terceira forma de relação objetal: a relação com objetos transicionais.

Esta terceira área, que Winnicott chamou de transicional, constitui-se tanto da realidade subjetiva quanto da vida externa, existirá “como lugar de repouso para o indivíduo empenhado 
na perpétua tarefa humana de manter as realidades interna e externa separadas, ainda que interrelacionadas" (WINNICOTT, 1975, p. 15).

O surgimento desta área da transicionalidade alia-se ao estudo da primeira possessão, pois o interesse recai no intervalo entre o que é vivido como subjetivo na interface com o objetivamente percebido. Ao falar em transicionalidade, o autor aponta dois modos de expressão ou apresentação sinalizadores de que o desenvolvimento desta dimensão está em curso: os fenômenos transicionais e os objetos transicionais.

Os fenômenos transicionais se relacionam a própria experiência autoerótica dos bebês, que fazem supor os primeiros movimentos das atividades de pensar e fantasiar em bebês. Essas atividades podem ser observadas no sugar o polegar e ao mesmo tempo com a outra mão levar um objeto externo à boca (ponta de lençol, cobertor, babador etc.), nos movimentos de segurar ou chupar pedaços de tecido, acariciar objetos macios e separar pequenos fragmentos dele (como lã de cobertor, por exemplo) ou mesmo movimentos produzidos com a boca acompanhados por sons.

Objetos transicionais se traduzem mais pela descoberta de objetos macios ou outros objetos que podem ser utilizados pelos bebês, inicialmente nos momentos de sono, como auxílio no manejo da ansiedade. Acrescenta-se ainda que, pode não haver a escolha de um objeto, permanecendo, então, a relação com a própria mãe. Significa pensar que uma das funções do objeto transicional é manter um elo entre o bebê e a mãe para auxiliá-lo em seu processo de desenvolvimento.

Destaca-se que o que está em jogo não é tanto o valor simbólico do objeto, mas essencialmente sua realidade. Isto porque, a função do objeto transicional é auxiliar o bebê no trânsito do mundo subjetivo para o mundo objetivo ou realidade externa. Portanto, a existência concreta, real do objeto se faz importante para que o bebê a partir do relacionamento com ele (seja a mãe ou o seio) possa realizar a construção de símbolos que possam representar as relações que o bebê estabelecer.

Dias (2003) acrescenta que a realidade e o caráter simbólico do objeto transicional estão intimamente ligados a vivacidade e confiabilidade do objeto subjetivo e, este, por sua vez, depende da permanência e vitalidade do objeto externo, ou seja, a mãe-ambiente.

Assim, "não é o objeto, naturalmente, que é transicional. Ele representa a transição do bebê de um estado em que este está fundido com a mãe para um estado em que está em relação com ela como algo externo e separado" (WINNICOTT, 1975, p. 30). 
Com isso, nota-se que a dimensão da transicionalidade, inicialmente, se constitui em importante espaço para a construção do desenvolvimento psíquico de bebês, uma vez que esta dimensão permite experimentações no mundo tal como o conhecemos, facilitando a construção de uma espécie de ponte entre a realidade pessoal e criativa com a realidade do mundo externo, objetivo.

\footnotetext{
Experimentamos a vida na área dos fenômenos transicionais, no excitante entrelaçamento da subjetividade e da observação objetiva, e numa área intermediária entre a realidade interna do indivíduo e a realidade compartilhada do mundo externo aos indivíduos (WINNICOTT, 1975, p.93).
}

Essa área de transição entre as relações de objeto subjetivo e as relações com objetos externos é um modo de relacionamento que opera na fronteira daquilo que é, ao mesmo tempo, criado pelo bebê e percebido ou aceito no mundo. Esse último, a realidade compartilhada que é alcançada pelo bebê em seu desenvolvimento. Dessa forma, a relação com objetos transicionais não se caracteriza somente pelas relações com objetos concretos ou com a mãe, mas se revela mais como um modo de relacionamento, um modo de estar, que permite idas e vindas entre o mundo interno e o externo. Um modo de relacionamento que permite a ponte ou a aquisição do sentido de realidade para o bebê.

Esse crescimento do bebê vai conferindo a capacidade de fazer pequenas diferenciações de objetos, de forma lenta e gradual o bebê desenvolve a capacidade de transitar entre diferentes formas de contato com os objetos, o subjetivo, o transicional e o objetivamente percebido. É o começo da evolução e aquisição de uma posição de contato onde já percebe um objeto diferente dele, um objeto "não-eu".

A este objeto que é percebido como diferente dele, o bebê pode oferecer um tratamento impiedoso, desdenhoso, iniciando o processo que pode favorecer a conquista da capacidade de usar objetos.

No momento em que já existe um início de relação de objeto, o bebê já consegue se relacionar com objetos não-eu, diferenciados dele, mas observa-se que relacionamento de objetos e o uso de objetos são comportamentos diferentes.

O relacionamento de objeto pode ser entendido também como um acontecimento sem o contato com o ambiente, um tipo de relacionamento mais elementar onde o bebê se relaciona com os objetos subjetivos, com objetos que ele criou. 
Agora, o uso do objeto significa dizer que o bebê se relaciona com objetos reais, objetos que pertencem a realidade compartilhada, não mais apenas objetos da criação pessoal do bebê. Eles são percebidos como estando fora, são percebidos como externos ao mundo subjetivo do bebê.

Nas palavras de Winnicott, "o uso não pode ser descrito, a não ser em função da aceitação da existência independente do objeto, a sua propriedade de estar sempre ali" (WINNICOTT, 1975, p.124). Ressalta-se, porém, que entre o relacionamento e o uso do objeto existe um movimento do bebê, que auxiliado pelo ambiente vai permitir que ele perceba o caráter de externalidade do objeto. Esse movimento consiste na colocação pelo bebê do objeto fora de sua área de onipotência pessoal.

Estamos diante da outra construção: o objeto objetivamente percebido ou compartilhado. Como ele se torna um objeto que é reconhecido como diferente do bebê? Como ganha existência própria?

\footnotetext{
$\mathrm{Na}$ perspectiva winnicottiana, a agressividade desempenha papel fundamental no estabelecimento do contato com a realidade externa, tanto na distinção entre o eu e o não eu, quanto no reconhecimento do outro como diferente de mim. O amor, assim, é indissociável da agressividade, não só porque é sempre ambivalente, mas também porque a condição para amar é a capacidade de reconhecer a alteridade do objeto do amor" (LEJARRAGA, 2012, p. 45).
}

O que o autor mostra é que a agressividade presente desde o momento inicial de vida do bebê é um fator constituinte do amor, encontra-se face a face com esse, mas também é o elemento que promove a separação entre bebê e objeto, uma vez que, ao bebê a tarefa de diferenciar-se está em ação e, afastar os objetos não-eu é que possibilita ao bebê o reconhecimento da externalidade dos objetos do mundo e do objeto de amor.

Como na origem o objeto é subjetivamente percebido, ou melhor, ele é criação do bebê e ao mesmo tempo é o bebê, ao começar transitar e perceber que o objeto é encontrado, é independente, este objeto pode começar a ser percebido como não-eu e pode ser repudiado, evitado, afastado pelo bebê.

Esse movimento de afastamento se relaciona com movimento agressivo do bebê. Importante esclarecer que estamos falando em agressividade, mas Winnicott, distingue destrutividade e agressividade, pois esta última seria resultante das experiências destrutivas, ou 
seja, agressividade estaria no âmbito das relações com objeto externo estabelecido, assim, um momento mais avançado do desenvolvimento emocional.

Nesse contexto, agressividade é entendida como destrutividade, necessária nesse processo de aquisição do sentido de realidade e, ao mesmo tempo, aquela que é raiz da agressividade.

Retornamos ao ponto em que a relação com objeto, se refere ao relacionamento com objetos subjetivos e o termo uso de objetos está ligado ao relacionamento com objetos que são objetivamente percebidos, reconhecidos com existência própria. O objeto subjetivo precisa também ser objetivo, precisa ganhar o reconhecimento de sua externalidade.

É relevante a maneira como se dá este processo, pois o bebê inicialmente adquire a capacidade de relacionar-se com objetos e, a partir disso precisa destruir o objeto subjetivo. Esse movimento de colocação do objeto fora da área subjetiva do bebê é importante para que ele possa ser reconhecido como externo ao eu e ao mesmo tempo, consolidar a existência do bebê como um ser diferenciado, independente.

A aquisição desse sentido de realidade é auxiliada pelo impulso do bebê em destruir o objeto na fantasia e o objeto continuar ali para receber esta comunicação, ou seja, o objeto precisa sobreviver a destruição.

O sujeito diz ao objeto: "Eu te destruí,, e o objeto ali está, recebendo a comunicação. Daí por diante, o sujeito diz: "Eu te destruí. Eu te amo. Tua sobrevivência à destruição que te fiz sofrer, confere valor a tua existência, para mim. Enquanto estou te amando, estou permanentemente te destruindo na fantasia" (inconsciente) (WINNICOTT, 1975, p.126).

Esse é o papel importante do ambiente, a sobrevivência. Por sobrevivência se entende a capacidade do ambiente em permanecer o mesmo, mantendo-se presente para receber a comunicação, manter-se confiável e previsível, sem ações de retaliação. Com a sobrevivência do ambiente, o bebê confere valor a existência do objeto, pode amá-lo e iniciar um processo de destruição do objeto na fantasia. Pode, assim, fazer uso do objeto que sobrevive a destruição.

Deste processo, pode-se apreender que a destruição ocorre não apenas porque o objeto se encontra fora da área de onipotência do bebê, mas também, que é pela ação de destruição do objeto que o bebê o coloca fora da área da subjetividade. Somente a partir disso, o objeto adquire vida e autonomia própria. 
Winnicott esclarece dizendo que é apenas "através da sobrevivência real de objetos catexizados, que se encontram, na ocasião, em processo de serem destruídos por serem reais, de se tornarem reais por serem destruídos", que o bebê inicia uma vida no mundo dos objetos (WINNICOTT, 1975, p.126).

Em outras palavras, quer dizer que o objeto só pode ser destruído se ele for real (estiver sendo percebido como externo) e estiver presente para receber este impulso do bebê.

\begin{abstract}
A conquista dessa capacidade situa-se no estágio da dependência relativa, quando o bebê já começou a distinguir entre o eu e o mundo não eu, e atingiu certo status de unidade. Embora o lactente tenha iniciado o processo de desilusão e esteja começando a fazer uso de objetos transicionais, percebendo que estes não são totalmente subjetivos - nem objetivos - a mãe permanece sendo para ele um objeto subjetivo por mais tempo. O bebê deve, então, destruir a mãe como objeto subjetivo, criação sua, e reconhecer sua existência como parte da realidade externa, compartilhada (LEJARRAGA, 2012, p.59).
\end{abstract}

Aos poucos, o bebê vai adquirindo a capacidade de reconhecer a existência do mundo e a alteridade da mãe. Ele não perde seu objeto subjetivamente criado, mas destrói a ilusão de criação do mundo, descobrindo que o mundo lá estava desde o início. E o bebê concebe a existência da mãe como pessoa separada, independente dele. Embora algo como um sentimento de que o mundo foi criado e continuará a ser criado de forma pessoal se mantém.

Assim, o que o bebê destrói é uma ilusão, ou seja, expulsa da realidade subjetiva, mas o objeto real, a mãe, continua viva e presente. Como o objeto se mantém, permanece lá, então pode ser usado, porque está lá para ser usado pelo bebê. "Essa qualidade de 'estar sempre sendo destruído', torna a realidade do objeto sobrevivente sentida como tal, fortalece o tom de sentimento e contribui para a constância objetal. O objeto, agora, pode ser usado" (WINNICOTT, 1975, p.130).

Com a sobrevivência da mãe, o bebê adquire o sentido de realidade, que é reforçado pelo contato com o objeto-ambiente que sobreviveu, que se manteve sem mudança de atitude. Isto contribui para que o bebê reassegure seu amor pelo objeto e reforce a permanência do objeto, que então, pode ser usado e amado.

Ousamos transformar nossa epígrafe, para dizer que, tornar o amor real é expulsá-lo de você para que ele possa ser alguém e, então, ser compartilhado com esse outro alguém! 


\subsubsection{Algumas considerações sobre o brincar}

O brincar é uma experiência constituinte do desenvolvimento humano. Como vimos, ela aparece de forma rudimentar nos gestos do bebê e integra o próprio amadurecimento, sendo assim, finalizaremos esse capítulo com algumas considerações sobre a experiência do brincar.

Winnicott estudou com afinco a questão do brincar em crianças e adultos, desenvolvendo, inclusive, a compreensão de que a capacidade para brincar é uma conquista dentro do processo de amadurecimento pessoal.

Em seu pensamento, concebe a ideia de que o brincar é uma experiência que pertence ao estar vivo. É uma experiência que pertence ao âmbito da saúde, a capacidade de brincar revela não apenas o brincar como uma experiência em si, mas, sobretudo, que esta capacidade está fundamentada na experiência de estar vivo e criar o mundo, o que se deu no contato com um ambiente favoreceu ao processo de amadurecimento.

Intimamente ligada ao brincar, destaca-se a ideia do fazer para mostrar que "brincar é fazer" (WINNICOTT, 1971, p.63). Afirmar que brincar é fazer alia-se a noção de que ao relacionar-se com o mundo o ser humano precisa fazer coisas, não é suficiente apenas pensar ou desejar, é preciso uma ação, um movimento em direção aos objetos do mundo, o que também leva tempo.

Em $O$ brincar e a realidade, o autor reconhece que o brincar é algo natural e que a psicanálise e outras formas de psicoterapia se apoiam neste fenômeno para aperfeiçoar seus métodos e a compreensão de seus fundamentos. E diz:

\footnotetext{
é a brincadeira que é universal e que é própria da saúde: o brincar facilita o crescimento e, portanto, a saúde; o brincar conduz aos relacionamentos grupais; o brincar pode ser uma forma de comunicação na psicoterapia; finalmente, a psicanálise foi desenvolvida como forma altamente especializada do brincar, a serviço da comunicação consigo mesmo e com os outros. (WINNICOTT, 1971, p.63)
}

Ressalta-se que brincar é experiência, uma experiência que revela que muitas outras experiências foram vividas e integradas ao longo do processo de amadurecimento, resultando nessa capacidade que pertence ao viver e ao sentido de ser e estar vivo. 
Winnicott diz: "a característica essencial que desejo comunicar refere-se ao brincar como uma experiência, sempre uma experiência criativa, uma experiência na continuidade espaço-tempo, uma forma básica de viver”. (WINNICOTT, 1971, p.75)

A importância do brincar se revela em uma experiência criativa, espontânea e uma experiência de revelação do si mesmo. No brincar entra em jogo a liberdade de criação, a criança ou adulto podem ter a experiência de criar algo e fazer uso da área de onipotência pessoal. Ao lançar-se espontaneamente no brincar criativo, a pessoa permite que o que há de mais pessoal em si, se expresse e aconteça no compartilhar com outro.

"É no brincar, e somente no brincar, que o indivíduo, criança ou adulto, pode ser criativo e utilizar sua personalidade integral: é somente sendo criativo que o indivíduo descobre o eu (self)" (WINNICOTT, 1971, p.80).

O brincar pode ser compreendido como oportunidade para autoconhecimento, pois através do brincar a criança ou adulto pode experimentar-se criativo, ou melhor, experimenta a ilusão de ter criado o mundo, de criar o que precisa ou sonha. É esse brincar que permite a vivência da ilusão e do sonho favorece a descoberta, ou melhor, um conhecimento sobre aquele que brinca integrando aspectos das áreas subjetiva e objetiva.

Quando Winnicott discorre sobre as experiências de conquista para o indivíduo do estado integrado como pessoa, sobre a aquisição da experiência de sentir, que possui um dentro e um fora, uma membrana limitadora, ele não entende estas duas dimensões como conclusivas da constituição psíquica das pessoas. Inclui um enunciado, propondo a existência de uma terceira área ou dimensão da experiência humana, uma área intermediária de experimentação, a transicionalidade.

Observa-se, como já vimos, a importância que Winnicott atribui as experiências do bebê com o ambiente como formas do viver, ou melhor, a partir de experiências vividas como criações pelo bebê e sustentadas no tempo e espaço pela mãe, como a possibilidade de construção do sentido de ser, do sentido de real, de estar vivo, portanto, de um sentido de vida.

Este ponto é central para a compreensão do que vem a ser o brincar no pensamento de Winnicott. Entende-se que a relação de contato e aceitação com a realidade compartilhada nunca cessa, isto significa dizer que o ser humano tem a permanente tarefa de relacionar as áreas subjetiva e objetiva e, que a tensão gerada por esta tarefa é aliviada pela terceira área de experiência que não é contestada e está em continuidade direta com a área do brincar, 
principalmente, o brincar da criança pequena, aquele que proporciona a criança perder-se na experiência do brincar.

Desta forma, afirma que "o brincar tem um lugar e um tempo" (WINNICOTT, 1971, p.62). Não é dentro e tampouco é fora. O lugar do brincar é a área intermediária: a transicionalidade ou espaço potencial.

Podemos pensar que o espaço potencial se caracteriza por um "entre", se refere a uma experiência que acontece em um espaço entre o indivíduo e o ambiente, está relacionado aos aspectos que de início, une e separa o bebê e a mãe, nos momentos onde o amor é manifesto como fidedignidade humana, como sentimento de confiança do bebê na relação com a mãeambiente.

É possível dizer que a característica principal refere-se ao brincar como uma experiência que tem início na confiabilidade entre o bebê e sua mãe e, posteriormente, se estende em direção ao ambiente. Essas experiências permitirão que o bebê possa em pequenas doses conhecer o mundo e a medida de sua crescente capacidade relacionar-se com ele.

Retoma-se o que já se enunciou a pouco, enfatizando o brincar como experiência. Esta é a comunicação essencial do pensamento deste autor quando analisa o brincar. O brincar como experiência que retoma a criação, a capacidade de criar formas de viver, modos pelo qual a criança se experimenta, modos de experimentar objetos e se relacionar com pessoas e com o mundo. Tudo acontecendo ao longo do tempo e no mundo de objetos reais, uma experimentação do viver e da vida.

Assim, pensando a brincadeira como experiência, uma experiência em si mesma, ressalta-se que:

O conteúdo não importa. O que importa é o estado de quase alheamento, aparentado à concentração das crianças mais velhas e dos adultos. A criança que brinca habita uma área que não pode ser facilmente abandonada, nem tampouco admite facilmente intrusões. (WINNICOTT, 1971, p 76)

Aponta-se para o brincar em si mesmo, sem que o significado ou sentido do brincar assumam lugar central em detrimento da experiência. Considera-se como relevante o modo de estar, um modo de ser no brincar que promove o "estado de quase alheamento", ou seja, um modo de estar que não é interno, nem externo, mas intermediário, marcado por um tipo de concentração, uma possibilidade da criança "perder-se", ficar mergulhada nesse modo de ser. 
Este estado nos mostra como a criança é capaz de realizar movimentos de ida e vinda, de entrada e saída deste estado, no entanto, revelando ainda, como este trânsito também possui suas particularidades. Isto quer dizer que, ao brincar, a criança estabelece um tipo de relacionamento que a lança na experimentação das três dimensões conjuntamente, o que se expressa em uma certa luta da criança em deixar a brincadeira ou permitir que algo que não configura o espaço de experiência seja introduzido no brincar.

Aspecto importante a ser destacado se refere à questão da instintualidade. Segundo Winnicott (1971), o elemento instintual durante o brincar permanece ausente, no entanto, se ao brincar a criança experimenta excitação física instintual o brincar fica impedido, se estraga ou pode se tornar assustador.

Compreende que "o brincar é excitante nele mesmo e, sobretudo, pela precariedade que lhe é inerente. Seu território é o interjogo entre a realidade psíquica pessoal e a experiência de controle de objetos reais". (DIAS, 2003, p.243)

O brincar envolve a espontaneidade, aquilo que não tem forma determinada, caracterizase pela ausência de regras, o que o diferencia do jogar. Sendo assim, a emergência na brincadeira de algo amedrontador se deve mais ao caráter imprevisível que constitui o próprio brincar.

Como se pode ver, o brincar ocupa um lugar central no pensamento de Winnicott, entendido como uma experiência essencial do viver "o brincar e a experiência cultural; são coisas que vinculam o passado, presente e futuro, e que ocupam tempo e espaço" (WINNICOTT, 1971, p. 151). Desse modo, a capacidade de brincar fica compreendida como uma conquista do processo de constituição psíquica, indicativo de saúde que integra as bases do viver e da possibilidade de compartilhar e contribuir com a cultura, tecendo a construção da história do indivíduo no tempo e no espaço. 


\title{
1.5 Notas sobre Educação e Cuidados
}

\author{
"O que poderia reunir uma professora, uma mãe e um médico? \\ [...] A resposta, é claro, é que em algum lugar deste cenário existe uma criança. \\ A criança é o cimento que une estas pedras, e também é o terremoto que as separa ${ }^{12}$ ",
}

Chegamos até aqui e o leitor deve estar se perguntando: Por que uma pesquisa que se apresenta com objetivo de tratar da relação de cuidados de bebês em creches discorreu sobre cuidados maternos? E mais, o que isso tem com o campo da educação? Educação e cuidados se encontram?

Primeiramente, não pretendemos nos alargar nessa discussão, antes, propomos levar alguns pontos sobre o tema em consideração, partindo do mais simples para tentar mostrar possíveis aproximações e distanciamentos entre os temas.

Para tanto, partiremos dos significados que o dicionário oferta sobre essas palavras e suas origens, para, posteriormente, dialogar com outros modos de pensar e discorrer.

\begin{abstract}
Educação [do latim educatione]. S.f. 1) ato ou efeito de educar (-se); 2) processo de desenvolvimento da capacidade física, intelectual e moral da criança e do ser humano em geral, visando à sua melhor integração individual e social; 3) os conhecimentos ou as aptidões resultantes de tal processo; preparo; 4) o cabedal científico e os métodos empregados na obtenção de tais resultados; instrução, ensino; 5) nível ou tipo de ensino; 6) aperfeiçoamento integral de todas as faculdades humanas; 7) conhecimento e prática dos usos de sociedade; civilidade, delicadeza, polidez, cortesia; 8) arte de ensinar e adestrar animais; adestramento; 9) arte de cultivar as plantas e de as fazer reproduzir nas melhores condições possíveis para se auferirem bons resultados (FERREIRA, 1999, p.718).
\end{abstract}

Nota-se que nessa primeira aproximação com o termo educação, logo se destaca que se refere ao ato ou efeito de educar e, na sequência aponta para educação no sentido de um caminho através do qual pode-se desenvolver capacidades humanas. A partir disso, passa a ser descrita como conhecimentos ou habilidades adquiridas nesse processo, também como ciência e seus métodos para ensinar ou instruir etc.

12 (Winnicott, 1997, p. 89). 
Olhando também o significado da palavra educar, obtemos:

\begin{abstract}
Do latim "educare", que significa "educar, instruir" e também "criar". Essa palavra era composta por "ex", fora, e "ducere", guiar, conduzir, liderar. Há a ideia de que introduzir alguém ao mundo por meio da instrução era como "levar uma pessoa para fora de si mesma, mostrar o que mais existe além dela"13
\end{abstract}

Assim, acompanhando essa definição de educar vemos que remete a pensar que, além de instruir, educar também atinge o sentido de criar (dar existência a; amamentar, sustentar, imaginar etc.). Além da compreensão de inserção de alguém no mundo por meio de instrução, um ato de acompanhamento que conduz a pessoa para algo além dela mesma, apresenta algo além da própria pessoa.

Vejamos também o que se entende por professor, uma vez que, é assim que aquele que educa ou ensina também é conhecido. Então, tem origem no latim, professore, e refere-se: “1) aquele que professa ou ensina uma ciência, uma arte, uma técnica, uma disciplina; mestre; 2) homem perito ou adestrado; 3 ) aquele que professa publicamente as verdades religiosas" (FERREIRA, 1999, p.1644).

Interessante notar como duas nomeações tão correntes dentro da educação, não raramente tratadas como sinônimos, assumem sentidos tão diferentes quando vistas de suas raízes.

Enveredamos para outros pensamentos para ampliar um pouco mais essas ideias e continuar pensando, dessa vez, com educadores sobre a educação!

Iniciamos com questionamento: "Pode ser que educadores sejam confundidos com professores, da mesma forma como se pode dizer: jequitibás e eucaliptus, não é tudo árvore, madeira? No final, não dá tudo no mesmo?” (ALVES, 1982, p.17).

O autor nos esclarece que não. Não dá tudo no mesmo, pois segundo ele, o educador é aquele que tem uma face, um nome e uma história e, para quem o que se põe em jogo é a relação, um tipo de relação em que há ligação com os alunos, considerando que cada um é um, visto em sua especificidade, em seu caráter único, singular, com direito a nome e história. E completa, "a educação é algo para acontecer neste espaço invisível e denso, que se estabelece a dois" (ALVES, 1982, p. 18).

\footnotetext{
${ }^{13}$ Extraído de https://pt.wiktionary.org/wiki/educar em 19/02/2016.
} 
Ao falar em educador, afirma ainda o educador se define por vocação, tomado por algo que nasce de um amor e de uma esperança e, delimita para dizer que o educador se pauta pela pessoa, por uma identidade.

Em contraponto, afirma que "professor é profissão" e que, ao tratar educadores como professores, salta-se da pessoa para a função. Vamos esclarecer o que ele quer dizer com isso.

Alves (1982) comenta que há uma mudança trazida com a chegada do utilitarismo e dos modos de produção. Com essas mudanças, as pessoas passaram a ser pautadas por quanto produzem e, nesse processo a identidade sucumbiria a função. Exemplifica isso, dizendo que as pessoas ao serem indagadas sobre quem são, comumente respondem dizendo o que fazem. Segundo ele, essas mudanças abririam caminho para um tipo de gerenciamento e administração da personalidade das pessoas, uma vez que, aquilo que é feito e produzido, a função, pode ser medido, controlado, racionalizado. Assim, a pessoa desaparece e se restringe a um ponto imaginário em que várias funções permanecem presas.

Desse ponto de vista, afirma que o professor "é funcionário de um mundo dominado pelo Estado e pelas empresas. É uma entidade gerenciada, administrada segundo a sua excelência funcional, excelência esta que é sempre julgada a partir dos interesses do sistema" (ALVES, 1982, p. 19).

No ideal do autor, o educador seria aquele que resiste em abandonar suas visões, suas paixões e esperanças, o que ele chama de interioridade. Seu trabalho é regido principalmente por palavras e seu ato se conduziria "lá, quando a criança, com seus olhos virgens, olha para o todo amorfo e inominável ao seu redor, e a desordem gira em torno dela, até que a palavra lhe é dirigida, dando nomes, impondo ordem, fazendo nascer um mundo" (ALVES, 1982, p.28).

Depreende-se até aqui que educador seria aquele que privilegiando a relação com o outro em sua singularidade (tanto a própria como a do aluno) por seu ato-palavra apresentaria o mundo àquele que precisa estender-se além de si mesmo e encontrar o mundo.

Marilena Chauí (1982), discutindo o avanço da ciência e do que chama progresso tecnológico, aponta para a fragmentação do trabalho e a subtração cada vez mais ampla dos sentidos deste, onde as pessoas cada vez mais reduzidas a condições de objetos sócioeconômicos, manobrados pela política e pela estrutura burocrática-administativa, teriam impedidas a identidade pessoal, a responsabilidade social, a direção política e o direito à produção da cultura. 
A autora aponta para a transformação da pedagogia em ciência, principalmente a partir das reformas do ensino brasileiro após o ano de 1968, analisando as implicações em termos curriculares, considerando a criação de cursos profissionalizantes de ensino médio, os programas de licenciatura curto ou pleno em diversas áreas do conhecimento e os convênios entre empresas e escolas.

Nesse raciocínio, aponta que essa cara de progresso científico trouxe um elemento intimidador ao introduzir a noção de competência, que esclarece dizendo "não é qualquer um que pode dizer qualquer coisa a qualquer outro em qualquer lugar e sob qualquer circunstância" (CHAUÍ, 1982, p. 58).

Com isso, a autora quer chamar atenção para o fato que essa intimidação trazida pelo advento científico pedagógico se insere como um instrumento de dominação. Inserido nesse rol de instrumentação científica vamos chegar a figura do especialista, que passa a se interpor entre a experiência real de cada um e sua vida, ditando discursos de como se deve ser e viver.

Alerta ainda para o fato que essa intimidação não cessa por aí. Aquilo que é veiculado em forma de saber, não é o saber em si, mas a informação que chega banalizada e rasa pelo desconhecimento tanto ao nível de sua produção quanto de seu consumo.

De um modo diferente, ainda que pelos mesmos caminhos, Carlos Brandão (1982) nos brinda com a história do educador grego extraídas de pequenas estatuetas gregas de terracota. Conta ele, velhos escravos acompanhavam meninos e meninas a caminho da escola. Esse era conhecido como o educador que caminhava com as crianças para escola. Era o educador que levava a criança para o mestre de contas-e-letras, o fiscal do ensino.

O educador era o escravo, o substituto dos pais nobres na educação dos filhos. E aos seus cuidados não estava apenas a tarefa de conduzir as crianças à escola, bem como, guiá-las "pelos caminhos que havia na educação que dava a ela, à criança, com a vida e a sabedoria" (BRANDÃO, 1982, p. 75).

Ele, o educador, era o guia do saber que tornaria a criança grega em um cidadão adulto, educado, que significava ser capaz de compartilhar a vida em sua cidade, sua cultura e sociedade.

Vê-se então, que o educador era aquele que ensinava a criança a "tornar-se pessoa" em oposição ao mestre-escola que era responsável pela instrução formal (ler, escrever e contar). As esferas do saber sobre a vida, o mundo, o relacionamento social e o viver era dado pelo 
educador, portanto, “educava com o saber de sua pessoa, o mestre-escola instruía com o saber de sua técnica" (BRANDÃO, 1982, p. 76).

Estamos apontando para aspectos do educador que tratam de esferas relacionais. Com isso, queremos dizer que, o educador nas visões apontadas nos remete a pensar: a) a relação que estabelece com ele mesmo e suas "paixões"; b) a relação que ele estabelece com seus educandos; c) a relação que se estabelece entre o educador e o conhecimento e, d) a partir de si e da relação com o outro o educador transmite a educação.

Outro ponto que merece destaque na descrição de educador trazida por Brandão (1982) é a dimensão do cuidado. O educador era responsável em cuidar para que a criança chegasse à escola, era preciso zelar para que a criança se tornasse um cidadão, era preciso cuidar para que a criança aprendesse a viver.

Ora, mas o que significa cuidado?

Recorreremos novamente ao mais simples, cuidado, do latim cogitatu, significa pensado, pensamento, reflexão, ou mais especificamente, “1) atenção; 2) precaução, cautela; 3) diligência, desvelo, zelo; 4) encargo, responsabilidade, conta; 5) inquietação de espírito; 6) pessoa ou coisa que é objeto de desvelo. Adj. 7) pensado, imaginado, meditado; 8) previsto, calculado, suposto" (FERREIRA, 1999, p.589).

Cuidar é pensar! Como podemos notar, portanto, cuidado está diretamente relacionado com reflexão sobre algo, estar atento, dedicado. Inclui imaginar, meditar, supor, todas atividades ou ações ligadas ao pensamento sobre algo ou alguém.

Vamos misturar um pouco as coisas. E pensar que, educação é um exercício de cuidados, ao mesmo passo que ao realizar o cuidado à uma criança estamos oferecendo educação...

Do que foi dito até aqui, podemos apresentar algumas diferenças entre o educador e o professor. O primeiro, compreendido mais como alguém que acompanha, conduz e apresenta o mundo mediado pelo estabelecimento de uma relação com o outro e com o saber. O professor é aquele que é visto mais pelo exercício de uma função de transmissão do conhecimento em forma de informação, não indicando necessariamente a dimensão do cuidado em fazer surgir o mundo para a criança.

Que tal continuarmos nosso caminho? 
Como estamos vendo, ao pensar sobre o ato de educar ou sobre o que se pode compreender sobre educação, o fato importante parece se voltar para a pessoa do educador, entendido como aquele que possuiu uma identidade em seu fazer, tangenciando a relação com o outro apoiada em uma vocação, em que o amor e a crença no ato educativo o move.

O conhecimento que o educador possa ter e transmitir importa, mas, este, precisa estar alinhado com sua identificação com um fazer que considera as dimensões pessoais em jogo.

Nessa linha, ao pensar o âmbito da educação no desenvolvimento da criança, Winnicott alerta para as disposições presentes naqueles que trilham os caminhos da educação infantil.

[...] o treinamento não produz o bom cuidador de crianças. Não há esperança para o profissional que trabalha numa escola maternal que é sentimental, ou impaciente, ou insensível, ou desconfiado ou "superior". "Somente se candidatem aqueles capazes de amar" (WINNICOTT, 1997, p.80).

Alguma semelhança com o que dissemos durante nosso texto?

Há muito já se sabe sobre a centralidade da mãe na relação com seus filhos, especialmente em se tratando de bebês. Pois bem, ao falar sobre desenvolvimento infantil na perspectiva da relação da mãe com seu bebê, não quisemos mostrar apenas a importância da relação dessa dupla, mas apontar para os acontecimentos que constituem essa relação e parecem merecedores de igual destaque.

Pensando nisso, os cuidados maternos se inserem nessa discussão, não para reafirmar a presença e o papel da mãe como cuidadora única e insubstituível e, sim, no sentido de discutir a importância da continuidade de algumas formas de cuidados com os bebês, independentemente de quem os realiza.

Relevante é a relação de cuidados que se estabelece entre um adulto e um bebê. Uma relação marcada pela desigualdade de amadurecimento e pela dependência do bebê em relação ao adulto para manter-se vivo, em tudo que estar vivo implica, ou seja, além da sobrevivência biológica.

Nesse sentido, a relação de cuidados da mãe com seu bebê nos indica os caminhos de cuidados necessários e possíveis de serem realizados no âmbito da educação. Claro, considerando as diferenças entre o adulto-mãe e o adulto-educador, especialmente, pensando na ligação amorosa e íntima que pode ser intensa na primeira dupla e ausente na segunda. 
Pretende-se fazer notar, como discutimos ao longo dos capítulos anteriores, que importa a relação de cuidado que pode se estabelecer entre um adulto e um bebê, muito mais do que o tipo de cuidado e as técnicas de cuidar. Assim como, fundamentalmente, o que é necessário ser mantido é a continuidade dos cuidados, que serão diferentes dos cuidados maternos, mas que mesmo assim, podem preservar um sentido de regularidade, previsibilidade, tão caros para o estabelecimento da confiança, mantendo dessa forma, o amadurecimento dos bebês em curso.

Assinala-se que "não é necessário nenhum entendimento psicológico especial para este trabalho, mas é necessária uma grande tolerância, o que não é fácil encontrar nas pessoas" (WINNICOTT, 1997, p.81-82).

Novamente, não é tanto de técnicas, teorias ou métodos que se trata, mas sim, fundamentalmente de um tipo de relação que se estabelece ou não, o que recai sobre os modos de ser da pessoa que cuida, tudo isso, para facilitar que através dos cuidados o bebê se torne uma pessoa capaz de viver e se relacionar.

\footnotetext{
Nossa preocupação é a de proporcionar um ambiente adequado às crianças de colo, às que estão começando a andar e às mais velhas - ambiente este que dará a cada indivíduo a oportunidade de, aos poucos e a seu modo, tornar-se uma pessoa que tem um lugar na comunidade sem por isso perder sua individualidade (WINNICOTT, 2005, p.30).
}

Por outro lado, é de conhecimento que nem sempre é possível à criança encontrar um ambiente de cuidados adequados e, quando o ambiente que não facilita o desenvolvimento, é o próprio lar da criança o cenário pode se complicar.

Um desses complicadores pode estar relacionado a uma necessidade de adaptação ativa que não se realizou no começo de vida da criança, fazendo com que ela arraste solicitações a outras pessoas que cuidam delas, que não os pais. Em nosso caso, essas pessoas podem ser os educadores ou professores.

Mais conhecida como "mimo", essa adaptação ativa tardia dos que cuidam da criança nesses moldes pode ser alvo de muitas críticas e, apesar disso, como o "mimo" chega muito tarde, nem sempre a criança consegue se beneficiar ou, se conseguir, a solicitação poderá se dar em grau elevado e prolongado no tempo. Se esse tipo de cuidado for alcançado e oferecido à criança, pode gerar uma situação difícil, pois a criança mostrará uma condição de dependência que pode gerar temor do rompimento naquele que cuida. Ainda, assim, podem ser alternativas para essas crianças. 
Sendo assim, para aqueles que se veem envolvidos na tarefa de educar ou cuidar de crianças pequenas, essas considerações devem ser pensadas, tendo em vista que podem ser encontradas crianças em diferentes momentos de desenvolvimento. Segundo Winnicott, elas se apresentariam como:

a) crianças capazes de enriquecer-se a partir do que lhes é oferecido, e prontas a contribuir e tirar proveito do fato de estarem contribuindo;

b) crianças que requerem dos professores aquilo que o lar não foi capaz de proporcionar;

c) intermediárias ${ }^{14}$.

Diante disso, observamos que a educação de crianças pequenas, especialmente de bebês precisa levar em consideração que o conhecimento do mundo é realizado de uma forma específica em bebês e, que a realidade dos bebês também diverge da realidade de outras pessoas, principalmente de crianças maiores e adultos (GOMES, 2009).

Portanto, com a compreensão de que a construção da realidade tal como a conhecemos está em andamento no bebê e que o modo como ele se relaciona e consegue conhecer o mundo também é diferente, nos parece que ao educador a tarefa de continuar apresentando o mundo ao bebê se coloca como educação.

Educador poderia ser pensado como aquele que apresenta as relações com o mundo, aquele que começa apresentando a si mesmo, se mantendo presente, regular, contínuo nas relações de cuidados com os bebês. Aquele que se faz presente para a criança.

Como? Conduzindo, acompanhando, cuidando, amando... enfim, se relacionando com o bebê como pessoa que é!

Pensar o cuidado nessas bases, implica reconhecer a raiz comum entre educar e cuidar. Compreender que cuidar e educar são importantes em igual medida, pois ambos dizem respeito a formação de uma pessoa. Sendo que, o cuidar, favorece a formação da criança em seu desenvolvimento psíquico, ou seja, a formação de sua personalidade. O educar é ação que dá continuidade ao cuidado, formando a criança em seu desenvolvimento para a integração individual e social, enfim, capacitando a criança a se tornar um cidadão.

Agora, para formar uma pessoa em cidadão, antes, é preciso que haja uma pessoa a ser formada, nesse sentido, aqueles que cuidam dos bebês, estão contribuindo para a formação de

\footnotetext{
${ }^{14}$ (WINNICOTT, 2005, p.35).
} 
uma pessoa. Isso é uma tarefa delicada e de fundamental valor, tanto para a criança como para aquele que cuida.

Não é curioso notar que há reflexão no cuidado e também na educação? E que há relação e amor na educação e no cuidado? Será que apenas semanticamente? Pensamos que não! Talvez, seja necessário pensar na aproximação das fronteiras entre educação e cuidados... 


\section{Sobre o Método}

Duas creches foram acompanhadas durante esta pesquisa. Uma creche teve seu acompanhamento de maio de 2012 a março de 2013 e outra de maio de 2013 a dezembro 2013.

Antes do início das visitas, foram realizadas reuniões com as profissionais em conjunto com a equipe de coordenação para esclarecer o que era a pesquisa e o que seria feito.

Até que as profissionais e equipe técnica pudessem conhecer a pesquisadora, entenderem a natureza da pesquisa e do acompanhamento e, assim, criar um espaço para liberdade e confiança, algumas conversas de esclarecimento sobre a pesquisa foram realizadas.

A fim de facilitar a inserção da pesquisadora e tornar as visitas algo menos perturbador à rotina das creches, foram combinados os dias e horários em que as visitas aconteceriam. Desta forma, as creches receberam visitas semanais da pesquisadora por um período de 2 a 3 horas, que aconteceram regularmente sempre nos mesmos dias e horários em acordo com a creche.

Durante as visitas às creches, foram observados e acompanhados 24 bebês e as profissionais que cuidavam deles. Os bebês eram acompanhados até que completassem 18 meses ou até que findasse o período do ano letivo.

No decorrer das visitas, foram acompanhadas as diferentes rotinas das creches como: o momento de chegada e saída dos bebês, os momentos de trocas, brincadeiras, alimentação, cuidados de saúde; as interações entre os bebês e profissionais etc.

Além disso, para criar uma aproximação e uma relação de confiança com as profissionais diretamente envolvidas nos cuidados das crianças e com os bebês, buscou-se aprender algumas das tarefas exercidas nos cuidados com os bebês e, quando havia espaço, estas tarefas eram com eles compartilhadas.

Sendo assim, a pesquisadora ajudava a alimentar os bebês, levá-los ao espaço reservado para brincadeiras, colocava-os para dormir, acolhia os choros, limpava os narizes, brincava com os bebês, ajudava a receber e entregar as crianças aos pais etc.

Eram nesses momentos que as observações dos cuidados das profissionais com os bebês aconteciam e se notava como se estabeleciam essas relações entre eles (profissionais e bebês). 
Essas estratégias foram pensadas para facilitar o relacionamento com as profissionais e manejar a presença da pesquisadora no contexto. Levou-se em consideração que estas profissionais teriam suas tarefas acompanhadas e observadas, o que poderia gerar ansiedades e dúvidas se estariam sendo avaliadas, assim como levantar desconfianças e hostilidades.

Importante mencionar que para se abrir a possibilidade de falar sobre os bebês e os cuidados a eles dispensados, bem como, conhecer as histórias dessas crianças, a partir do que lhes acontecia no espaço da creche, as conversas não se iniciavam focadas nas crianças, mas em temas apresentados pelas profissionais.

Nessas conversas, buscava-se compreender também as dificuldades, as dúvidas, expectativas e afetos implicados nessas relações. Essas interlocuções com as profissionais tinham como objetivo provocar algumas reflexões sobre os cuidados com as crianças, as práticas e as relações.

Para realização da análise dos dados levantados neste estudo utilizaremos conceitos do referencial psicanalítico abordado nesse estudo. Elegendo para análise e discussão dos dados os operadores presentes nesse referencial, especialmente, os operadores que tratam das relações de cuidados: identificação, holding e handling. 


\section{RESULTADOS}

\subsection{O Contexto das Creches}

A pesquisa foi desenvolvida em duas creches da cidade de São Paulo, durante os anos de 2012 e 2013. Para efeitos de não identificação das creches acompanhadas, nesse texto denominaremos de creche A e creche B.

As creches com as quais trabalhamos faziam parte do rol de creches da Pesquisa "Metodologia IRDI - uma intervenção com educadoras de creche a partir da psicanálise".

A realização da Pesquisa IRDI nas creches contou com a participação de outras pesquisadoras. Como a creche $\boldsymbol{A}$ era maior e possuía número elevado de bebês foram convocadas cinco pesquisadoras, sendo três delas para o Berçário I e duas para o Berçário II, divididas em períodos diferentes e dias da semana intercalados.

Esta pesquisadora realizou acompanhamento dos bebês a partir do berçário I e os manteve em todo período da pesquisa. Destaca-se que o acompanhamento da creche $\boldsymbol{B}$, no período mencionado, foi realizado apenas por esta pesquisadora.

Embora este trabalho tenha sido desenvolvido a partir das observações desta pesquisadora, parece importante ressaltar essas informações, uma vez que a presença da pesquisadora para acompanhamento dos bebês com as professoras configura o campo da pesquisa e pareceu ter efeitos sobre os funcionários das creches, principalmente as educadoras/professoras.

Há diferenças importantes entre as creches, uma delas, que agora enfatizamos, se refere ao modo como as funcionárias das creches eram nomeadas. Na creche $A$ eram chamadas de educadoras e na creche $B$ as funcionárias eram tratadas por professoras. Assim, nosso texto vai acompanhar as diferentes nomeações para cada creche, preservando a singularidade das instituições. 


\section{A creche A}

O acompanhamento da creche $\boldsymbol{A}$ aconteceu no período de março de 2012 à março de 2013, período extenso, pois houve férias das crianças e das educadoras, momentos que não foram possíveis de acompanhar a dupla educadora-bebê.

A creche $\boldsymbol{A}$ situa-se dentro de uma instituição e se caracteriza como benefício aos funcionários. Esta creche funciona como um Centro de Desenvolvimento de Educação Infantil (CEDEI) e conta com a Coordenadoria de Educação da região para homologação do planejamento escolar, uma vez que, essa creche não possui credenciamento com a Secretaria Municipal de Educação de São Paulo.

A creche possui capacidade para atender aproximadamente 200 crianças a partir dos três meses de idade que permanecem até completarem quatro anos. As matrículas têm início no mês de janeiro, prolongadas para qualquer época do ano para o Berçário. Para crianças acima de 12 meses de idade, a creche segue critérios de inserção socioeconômicos devido à capacidade de atendimento.

Uma particularidade dessa creche era não funcionar com um número determinado de vagas para crianças dos berçários. Dessa forma, o ingresso de novos bebês acontecia o ano todo. A cada semana podia-se ver um ou dois bebês novos no berçário.

Notava-se que esta falta de período delimitado para entrada de novos bebês gerava tensão entre as educadoras que se sentiam sobrecarregadas e temiam não poder cuidar de tantos bebês. As educadoras mencionaram que ao final do ano de 2011 alcançaram o número de 50 bebês no berçário I.

\section{O espaço}

O espaço físico da creche era formado por um bloco de salas divididas por um corredor longo. Quando se entrava na creche, ao lado direito ficavam as salas dos berçários, pré-mini, 
mini-grupo e maternal. Ao lado esquerdo, situavam-se todas as salas que compunham a estrutura administrativa da creche e a enfermagem.

Notava-se que as salas da ala administrativa não possuíam janelas, pois elas faziam divisa com a parte interna do andar térreo da instituição. Esta organização física não favorecia a iluminação e a circulação de ar no espaço da creche, o que permitia sentir diversos odores ao entrar no prédio, além da sensação de confinamento.

As salas dos berçários e outros grupos de crianças eram todas muito amplas e faziam divisa com a parte externa do prédio, possuíam grandes janelas e uma área externa que era possível acessar das salas. Esta área externa se constituía de um longo corredor que acompanhava a extensão da creche. Apesar de longo o corredor era estreito e possuía uma pequena área de lazer para as crianças. Havia também um pequeno pátio externo com alguns brinquedos para balançar (espécie de cavalinhos) e alguns triciclos, uma área onde o sol incidia.

Todas as salas possuíam aspecto de aquário, com vidros de observação fixados nas paredes como se fossem berçários de maternidade, porém de menores dimensões. Em algumas salas, esses aquários eram fechados com papel colorido que impediam a visualização da parte interna da sala, algumas continham um aviso alertando sobre a proibição de ficar olhando pelo vidro.

No corredor era possível ver diversos murais com informações sobre a creche, sobre aspectos relativos à nutrição e educação, além de motivos decorativos.

$\mathrm{Na}$ entrada da creche, havia uma pequena recepção que não apresentava bom estado de conservação. Contava com um pequeno portão de madeira entre a porta da recepção e o acesso ao corredor da creche. Nesta recepção havia uma espécie de porteiro, uma funcionária que permanecia em muitas ocasiões conversando com as pessoas ou vendendo roupas infantis para as mães.

O espaço geral da creche apresentava aspectos de sujeira e certa desorganização. O tratamento dispensado pelos funcionários da creche aos visitantes era descuidado e pouco acolhedor.

A sala onde ficavam as crianças do Berçário I (BI) era ampla, possuía alguns colchonetes no chão, que ficavam dispostos no centro da sala ou em um dos lados. Eram cobertos por lençóis e contornados por grandes almofadas que eram utilizadas como aparadores dos bebês ou mesmo como apoio ou colchão para os pequeninos. 
Havia um quadro na parede onde ficavam penduradas as chupetas dos bebês e outro quadro com os nomes das crianças e marcações sobre a rotina diária de cuidados físicos das crianças na creche, como alimentação, banhos e trocas.

O berçário dispunha de algumas cadeirinhas de balanço, cadeiras do tipo bebê conforto com forros já muito usados e desbotados. Havia uma pequena instante com alguns brinquedos gastos e outros produzidos com material reciclado, alguns móbiles e uma bola de tamanho grande pendurada do teto a pequena distância do chão. E um espelho fixado em toda a extensão de uma das paredes da sala.

A sala possuía vários berços, alguns com brinquedos pendurados nas laterais ou pequenos móbiles, muitos que já não funcionavam. Tanto no início da sala como no fim havia uma pequena cerca de madeira que limitava a área de troca e a área de alimentação do restante da sala.

O berçário II (BII) também era uma sala ampla, com o mesmo formato do berçário I. No entanto, a sala era mais escura e fria, parecia receber menos sol. Também havia o cercado de madeira para dividir os espaços de troca e alimentação. Contava com berços, alguns bebêsconforto e também cadeirões para o período das refeições.

Havia alguns brinquedos de espuma em formato de rampas para as crianças subirem, dois bichinhos de borracha do tipo cavalinho para crianças sentarem e pularem. Algumas bolas de diferentes tamanhos e alguns poucos brinquedos e materiais diversos (potes plásticos, latas, colheres, cestos etc.). A sala dispunha de alguns colchonetes ao centro ou aos cantos da sala e também um espelho na extensão de uma das paredes.

A sala do pré-mini ficava localizada em um espaço que agrupava duas salas separadas por um pequeno corredor que dava acesso à área externa da creche. Na sala do pré-mini, havia uma divisória que a separava em dois espaços, um que contava com colchonetes e outro que contava com mesinhas e cadeirinhas para as refeições. Essa sala era bem pequena e quase não havia brinquedos à disposição das crianças.

A sala do maternal situava-se no outro extremo do corredor. Esta sala permitia acesso ao espaço do refeitório e do pátio externo. A sala contava com uma mesa lateral com alguns brinquedos gastos e alguns quebrados, também possuía alguns colchonetes ao centro. Essas salas não dispunham das cercas de madeira como divisórias do espaço interno da sala.

Todas as salas da creche, desde berçários até o maternal dispunham de um televisor e um aparelho de DVD. A televisão, costumeiramente exibindo vídeos infantis (com desenhos e 
músicas - galinha pintadinha, por exemplo) era um recurso bastante utilizado em todos os ambientes para entreter bebês e crianças. Mesmo no berçário I, os pequeninos de quatro meses eram expostos à televisão.

As malas e mochilas dos bebês e crianças permaneciam dentro das salas, sendo que nos berçários I e II e mini-grupo, o espaço reservado eram pequenos armários abaixo dos balcões de trocas dos bebês. E no grupo maternal os pertences das crianças ficavam em cabides dispostos na parede fora do alcance das crianças.

Havia grande investimento em ações higiênicas, perpassadas por cuidados de enfermagem, assepsia, uso de álcool em gel para limpeza das mãos (utilizado em diversas situações pelas educadoras, principalmente nos momentos de trocas), luvas plásticas e propés. Procedimentos que contrastavam com pequenos resíduos de biscoitos pelo chão, que as crianças pegavam e ingeriam.

Existia solicitação de uso de propé para entrada na sala dos berçários I e II, no entanto, verificava-se que as educadoras utilizavam o propé por cima dos sapatos, caminhando inclusive em cima dos colchonetes onde ficavam as crianças. Curiosa era regra para troca dos propés para ir de um berçário a outro com a alegação de que as bactérias entre os berçários eram diferentes.

Toda a alimentação das crianças era preparada no setor de Nutrição da instituição, e as mamadeiras entregues embaladas e etiquetadas com os nomes das crianças, especificando o tipo de leite. A alimentação salgada era colocada em pequenos potes descartáveis. O transporte era feito em carrinhos por funcionários do setor de nutrição, que entregavam a alimentação pelas janelas das salas.

\section{A rotina da creche}

Essa creche funcionava com atendimento as crianças de segunda à sexta-feira das $6 \mathrm{~h}$ às 19h00. A permanência das crianças ocorria em diferentes turnos, de acordo com os períodos de trabalhos dos pais. As crianças eram acompanhadas por suas mães ou pais no momento da chegada ou saída da creche. E todas as crianças eram recebidas ou entregues pelas educadoras na porta das salas dos berçários. 
Algumas crianças frequentavam a creche somente no período da manhã ou da tarde (6 horas), havia aquelas que permaneciam em período integral ( 8 horas) e algumas que chegavam a ficar 12 horas (o que podia ocorrer em dias alternados).

Assim, viam-se crianças que entravam na creche a partir das 6 horas da manhã e as chegadas aconteciam ao longo do período da manhã. Nesse período, havia um pequeno lanche antes do intervalo de almoço, este acontecia entre $11 \mathrm{~h} 00$ e $13 \mathrm{~h} 00$.

Após o almoço seguia-se o período de descanso, momento em que as crianças eram colocadas para dormirem, isso acontecia entre $12 \mathrm{~h}$ e $14 \mathrm{~h} 00$. Terminado o período de descanso ocorria a partir das $14 \mathrm{~h} 00$ o horário das mamadeiras para os bebês mais novos e um lanchinho com biscoitos e sucos para os mais velhos. O jantar era servido a partir das $17 \mathrm{~h} 00$.

Nos horários de almoço e jantar as educadoras dos berçários recebiam reforços de outras funcionárias, tendo em vista que o número de crianças era grande no momento do almoço e, o número de educadoras era menor no período do jantar.

O Berçário I funcionava com os cuidados de quatro educadoras, variando de acordo com os horários. Em horários de almoço e trocas para saída de algumas crianças podia-se acompanhar quatro educadoras. Mas, ao final da tarde, o berçário permanecia com duas educadoras e contavam com a ajuda de uma terceira nos horários de janta.

O cenário do berçário II era diferente, contavam com um número um pouco menor de crianças, aproximadamente 20 crianças com duas educadoras cotidianamente, às vezes, contavam com três educadoras, pois esta última incorria em afastamentos do trabalho.

Observamos que era comum a troca de profissionais nos berçários, havia vários rodízios de educadoras no berçário I. As educadoras trabalhavam em turnos de 6 horas, o que gerava três mudanças de profissionais durante o dia. Manter uma presença sempre constante entre as educadoras como referência para os bebês não era possível nos cuidados dessa creche.

Mencionamos que a chegada de novos bebês ao berçário I era constante e a qualquer época do ano. Como o número de bebês crescia ao longo dos meses, aqueles que apresentavam maior desenvolvimento sensório-motor, eram transferidos de turma, desdobrando em mudança de educadoras.

Além disso, havia rotatividade de pessoal, por demissão ou por adoecimento. Acompanhamos algumas educadoras que se demitiram e outras que tiveram afastamento por motivos de saúde. Assim, outras funcionárias eram admitidas para substituí-las. 
Esse contexto que encontramos permitiu que tivéssemos contato com diferentes educadoras. No entanto, o trabalho de acompanhamento dos bebês com elas parecia sempre um recomeço.

\section{As educadoras e os bebês nos berçários}

A sala do berçário I era composta por quatro educadoras que se ocupavam de 36 bebês de três aos nove meses de idade no momento em que essa pesquisa se iniciou na creche.

Logo de início, chamava muita atenção o choro dos bebês. O que se observava era que choravam sem parar e as educadoras passavam por eles sem verificar o que estava ocorrendo. Havia bebês de diferentes idades. Verificava-se que os mais novos (alguns chegavam à creche aos três ou quatro meses de idade) choravam até exaustão. Não observamos nenhum tipo de adaptação dos bebês aos primeiros dias de creche, eles bebês ficavam aos cuidados da creche de forma imediata e por períodos inteiros sem que as mães permanecessem com seus bebês, sem dosagem inicial do tempo de permanência na creche.

As educadoras, na grande maioria das vezes, percebiam o choro dos bebês como algo necessário, porque precisavam aprender que estavam na creche e não teriam colo como em casa. Isto era verbalizado como: "A mãe disse que ele gosta de um colinho!" ou "Em casa ele está acostumado ficar o tempo todo no colo".

Verificava-se que muitas crianças eram colocadas de bruços e quando choravam estavam com o rosto colado ao chão, colchonetes ou colchões dos berços e, frequentemente, se observavam pequenas "pocinhas" como vestígios do choro, o que parecia indicativo do tempo que passavam chorando.

Outra maneira, talvez, a mais frequente era ignorar o choro ou reclamar do barulho que o choro coletivo alcançava no berçário. Certa vez, a pesquisadora conversando sobre o choro dos bebês e perguntando por que um garotinho chorava, ouviu: "eles choram, um chora, mas logo tem outro que chora mais do que ele, então não adianta chorar”. Parecia que o choro dos bebês não era algo a se ocupar ou não havia o que ser feito. 
Também era algo comum ver, crianças nos berços, sentadas nas cadeiras bebê conforto ou presas em cadeiras de balanço. Isso acontecia tanto com os bebês bem novos como com aqueles que já se locomoviam. Especialmente com esses últimos, impedia que ficassem circulando pela sala. Parecia uma forma de diminuir a circulação das crianças sem ter que dispensar muita atenção às dificuldades que resultavam da locomoção dos bebês.

Notava-se que de forma geral, as educadoras estabeleciam pouco contato corporal com os bebês, sendo que alguns deles pareciam invisíveis porque suas presenças não chegavam a ser levadas em consideração, mesmo que estivessem aos prantos. Outros pareciam não ser dignos de nota porque eram "bonzinhos", esses bebês que não davam trabalho e raramente choravam.

Devido à baixa frequência de interação entre as educadoras e os bebês, algumas vezes era possível observar a relação somente no momento da troca, essa era realizada de forma rápida, mecânica e pouco espontânea, talvez devido acompanhamento pela pesquisadora.

As trocas de fraldas aconteciam durante quase todo o tempo, mas principalmente próximo ao horário de saída de algumas crianças. Os cuidados eram mais voltados para higienização e troca de roupa dos bebês e pouco contato pessoal se estabelecia. Os momentos de conversa, as trocas de olhares e brincadeiras com os bebês eram raros e breves.

Dessa forma, o contato corporal com as crianças era pouco frequente e não estimulado. Inicialmente, observamos que, quando os bebês entravam em ritmo de choro, as educadoras buscavam recursos de bastante intensidade, como palmas, músicas, batiam bola e colocavam músicas infantis, o que chamava atenção deles momentaneamente. Raras vezes elas pegavam, falavam, brincavam ou ofereciam brinquedos como alternativa.

De maneira geral, o manejo dos bebês era realizado de forma muito automática e rápida. Não havia preocupação com a maneira de segurar os bebês ou movimentá-los, eles eram pegos de forma muito abrupta e mantidos ao colo de forma muito insegura, sem sustentação da cabeça nos casos dos mais novos e um tipo de sustentação lateral ao corpo no caso dos maiores (eram seguros como pacotes de arroz). Esta forma de segurar mantinha os bebês suspensos no ar e sem contato corporal e visual com as educadoras.

Verificava-se preocupação com cuidados de higiene e alimentação, embora se observasse que, algumas vezes, havia bebês que ficavam sem alimentação, eram esquecidos, talvez pelo número grande de bebês, ou ainda porque estavam dormindo ou porque permaneciam invisíveis. 
A hora da alimentação dos bebês acontecia de forma coletiva, as educadoras agrupavam as crianças para dar as mamadeiras. Para a maioria das crianças as educadoras entregavam as mamadeiras na mão para que os próprios bebês segurassem. Este procedimento acontecia mesmo com os menores, aos cinco ou seis meses e, como a maior parte dos bebês não eram seguros ao colo, recebiam uma espécie de apoio com um rolinho de pano para as mamadeiras em suas próprias mãos.

Poucas ocasiões acompanhou-se a hora do jantar dos bebês, porém os cuidados nesta hora eram realizados com muitas crianças ao mesmo tempo, era um fazer mecânico e automático.

Ainda em relação à alimentação, para os bebês com até um ano de vida, que se encontravam nos berçários I e II havia períodos de amamentação materna. As visitas das mães aconteciam duas vezes ao dia, nos períodos da manhã e da tarde.

Outro aspecto demonstrado pelas educadoras era a crítica feita às mães, a maior parte delas insinuava falta de cuidados das mães relativos à higiene, alimentação e saúde dos bebês. As mães também eram criticadas por mimarem seus filhos.

Curiosamente se observava visitas das mães fora de horário. Elas apareciam em intervalos para almoço ou descanso do trabalho. Isto acontecia com as mães que estavam amamentando e com aquelas cujos bebês que já não eram amamentados. Este fato irritava as educadoras que se queixavam desse comportamento das mães.

Isso era possibilitado pelo fato da creche estar inserida no ambiente de trabalho das mães o que facilitava o acesso delas à creche.

Algo que acontecia, mas que a primeira vista não era verbalizado pelas educadoras se referia a predileção por algumas crianças, esta preferência revelava-se nas observações e conversas sobre as crianças. Vimos que os bebês também tinham suas preferências e mostrávamos isso a elas.

No B II, estas dificuldades se acentuavam porque o contato com os bebês era ainda menos frequente, as educadoras permaneciam mais distantes da cena, deixando os bebês circulando sozinhos pela sala ou incentivando que eles brincassem. Uma relação mais próxima com os bebês não era verificada, excetuando o momento de troca, que se assemelhava com o movimento automático do B I. 


\section{As relações na creche $A$ : educadoras, equipe da creche e pesquisadora.}

Logo no início, precisamente, após nossa primeira visita para acertar aspectos formais da pesquisa, chamou nossa atenção uma recomendação da psicóloga da creche. Foi solicitado às pesquisadoras que tivessem cuidado com a forma de comunicação com as educadoras. A comunicação deveria ser feita de forma simples e adequada a compreensão das educadoras, com recomendação de que não fossem utilizadas postura e linguagem psicanalítica na interação com as educadoras.

As visitas de acompanhamento despertaram diferentes reações nas educadoras e equipe técnica, entre elas, receptividade de algumas, curiosidades, desconfiança, medos e hostilidades de outras. No começo da pesquisa, as educadoras se mostraram pouco disponíveis para o contato, evitavam conversas, faziam alguns comentários sobre o comportamento de observação das pesquisadoras, chamando-nos de "árvores".

Outras diante das tentativas iniciais de conversar com elas sobre os bebês e o desenvolvimento deles, faziam comentários de oposição, como por exemplo, que não se podia falar com bebês de forma melódica, era preciso ensiná-los a falar corretamente etc.

Como o choro era algo pronunciado na creche, em todas as visitas, logo ao chegar a pesquisadora abordava os bebês que estavam chorando sem assistência e verificava com as educadoras o que poderia estar acontecendo. Quando era necessidade de cuidados de alimentação ou troca, as educadoras pegavam a criança. Os que permaneciam, a pesquisadora pegava ao colo, posicionava de forma que pudessem olhar o ambiente.

Com os bebês que já sentavam, a pesquisadora colocava todos sentados em volta dela, conversa, brincava, oferecia brinquedos e aos poucos eles paravam de chorar. Os que estavam chorando sozinhos nos berços eram pegos e trazidos para a "roda".

Somente depois dessas ações a pesquisadora começava as observações, conversas e intervenções, contando que essas eram as prioritárias, digamos assim.

Com relação aos procedimentos éticos e formais da pesquisa, a equipe técnica da creche preferiu administrar o levantamento dos Termos de Consentimento junto às educadoras.

No processo de coleta dos Termos de Consentimento com as educadoras, uma mostrouse muito contrária ao preenchimento completo do termo, sendo necessária devolução do 
documento a creche por duas vezes, pois os dados pessoais foram preenchidos por etapa. Foi entregue, inicialmente, apenas com o primeiro nome e a assinatura, somente depois foi sendo preenchido com outras informações.

A Coordenadora da creche explicou que a educadora estava preocupada com os dados. Foi esclarecido o motivo do preenchimento do termo e a possibilidade de conversa com a educadora para dirimir as dúvidas e tranquilizar quanto à utilização do documento.

$\mathrm{Na}$ época, houve solicitação para que a pesquisadora conversasse com a educadora. Em conversa, constatamos que a educadora já havia preenchido o documento e conversado com outra pesquisadora sobre o assunto. Entregou o documento, porém demonstrou hostilidade na ocasião.

Ao retomar a conversa com a Coordenadora, essa esclareceu que solicitou à pesquisadora que conversasse com a educadora para evitar a hostilidade dela, o que era bastante frequente e não estava suportando.

Notamos a existência de conflitos entre a equipe, onde os problemas não eram resolvidos. Evitava-se abordar, falar ou enfrentar as situações ou problemas. Apesar de conhecidos, parecia que não se podia tocá-los.

A formação das educadoras desta creche também é outro dado que chama atenção. $O$ quadro de educadoras da creche contava com uma diversidade de formações e não formações, pois havia profissionais da área de enfermagem (auxiliares ou técnicos de enfermagem), psicóloga, pedagogas e auxiliares de serviço, estas últimas sem formação técnica.

Além do quadro de educadoras, esta creche contava com outros profissionais que compunham a equipe da creche. A equipe técnica da creche era constituída pela Diretora (Assistente Social) e uma Vice-diretora, uma Coordenadora Pedagógica, uma Assistente de Coordenação (Pedagoga), uma Psicóloga e uma Assistente Social.

Também havia um médico pediatra e uma equipe de enfermagem, esta composta por uma Enfermeira e duas técnicas de enfermagem. As crianças eram acompanhadas pelo pediatra que fazia exames de rotina e a equipe de enfermagem era responsável por administrar medicações e cuidados de enfermagem em casos de adoecimento e acidentes (quedas, mordidas etc.). 


\section{Sobre as mudanças na creche $A$}

Aspecto que nos chamou muita atenção era que ocorriam mudanças dos bebês de uma turma para outra. Verificamos que os bebês eram transferidos do berçário I para o berçário II, a cada quatro meses aproximadamente. E essas mudanças ocorriam assim do berçário II para o pré-mini, deste para o maternal. Todas essas mudanças de ciclo dentro da creche implicavam em mudança de espaço físico e educadoras.

Conversando com as educadoras e observando a dinâmica da creche, pudemos compreender que o critério de transferência dos bebês era pautado no desenvolvimento sensório-motor. Isto porque, a partir do momento que os bebês adquiriam maior capacidade de controle corporal, como sentar, agarrar objetos, engatinhar, ficar em pé e andar, enfim locomoverem-se, começava-se a pensar na transferência.

No berçário II, os critérios eram os mesmos, os bebês eram transferidos para o ciclo do pré-mini e maternal de acordo com a conquista da capacidade de andar, bebês que alcançavam esse desenvolvimento ou andavam bem eram transferidos para o pré-mini e os demais para o grupo maternal.

Com as capacidades de locomoção adquiridas, era o momento onde víamos os bebês buscarem as educadoras preferidas, quando elas, deles se afastavam. Eles engatinhavam na direção delas, se seguram e apoiavam nas cercas de madeiras. Os bebês ficavam olhando para elas, chamavam e, às vezes, agarravam e se enroscavam nas pernas delas.

Em dado momento, a creche acordava uma data para a transferência dos bebês e, então, os escolhidos passavam por um período de adaptação, na semana anterior ou na própria semana da mudança.

$\mathrm{Na}$ adaptação, os bebês eram levados por uma das educadoras do B I para o berçário II. Lá permaneciam um pequeno tempo, algumas horas, em companhia da educadora conhecida e das novas educadoras e crianças do B II. Essa era a adaptação que a creche promovia para a transferência dos bebês de uma turma para outra. Adaptação, nesse contexto, era entendida como algumas horas espaçadas em poucos dias de contato dos bebês com outro espaço e outras pessoas. 
Com as mudanças, percebemos que, logo no começo, os bebês transferidos choravam muito. Era comum chegar à sala e encontrá-los, chorando e sozinhos. Às vezes, estavam brincando, mas, se uma das educadoras conhecidas entrasse na sala e fosse vista por eles, viase imediatamente um sorriso seguido de choro. Os que já engatinhavam ou andavam se dirigiam para perto das cercas de madeira, o mais perto que conseguiam chegar das educadoras.

Quando os bebês transferidos encontravam a pesquisadora nas visitas semanais de acompanhamento, eles rapidamente se aproximavam e buscavam contato, traziam brinquedos, propunham brincadeiras, choravam, procuravam colo...

Durante o tempo de acompanhamento, vimos essas mudanças acontecerem quatro vezes, a cada três ou quatro meses, aproximadamente, essas mudanças chegavam para todos... (bebês, educadoras e pesquisadora).

Salvo algumas exceções, era assim que aconteciam as transferências. Dizemos exceções porque com o tempo percebemos que, alguns bebês (os preferidos), às vezes, escapavam ao crivo dos critérios e permaneciam por mais tempo no berçário I.

Na outra via, as educadoras também demonstravam seu apego aos bebês e o sofrimento pela separação. Antes das mudanças, elas buscavam mais contato com os bebês prediletos, faziam brincadeiras, trocavam carícias, faziam fotos!

Com a crescente confiança na pesquisadora, as educadoras contavam um pouco sobre os bebês, o que sabiam deles e como se sentiam com a separação. Revelavam que era difícil separar-se deles e, mesmo tão perto deles, não poderiam ir visitá-los, pegá-los ao colo, porque isso era visto como problema pelas educadoras do BII, pois alegavam que os bebês choravam mais, eles davam mais trabalho, o que atrapalhava a rotina de trabalho delas.

Esta proibição funcionava como regra na creche, pois os conflitos entre as educadoras e as reclamações em reuniões na creche, instituíra um rompimento de relações que era, segundo o que diziam, ordens da direção. Entretanto, os "dribles" à ordem se faziam e os encontros aconteciam, fossem em furtivas visitas ou em encontros promovidos pelas mães das crianças.

Outra situação que vimos ao longo do tempo era o "sequestro" de alguns bebês. Quando as educadoras ficavam com muitas saudades, elas buscavam os bebês e os levavam para o berçário I e passavam algum tempo juntos. Elas se divertiam quando eram flagradas pela pesquisadora nessas ações. E, diga-se de passagem, a pesquisadora também! 
Saber que éramos vistas como "árvores" foi possível em um momento de maior intimidade e confiança entre as educadoras e a pesquisadora. Elas puderam explicar que algumas pesquisadoras do grupo não conversavam e ficavam plantadas como se fossem “árvores”, principalmente no início do acompanhamento, onde elas só observavam.

Outro ponto interessante, foi o apontamento da possibilidade de haver preferências, notava-se maior espontaneidade das educadoras no cuidado com as crianças, desdobrando contatos e relações mais próximas e pessoais com os bebês.

Parecia que as educadoras apresentavam temor em revelar suas preferências, fazendo com que mantivessem essas relações em segredo, pois raramente eram flagradas em demonstrações de afeto como beijos, abraços, palavras amorosas, brincadeiras etc. O que parece ter se alterado, pois a afeição começou a aparecer na creche.

Na reunião de encerramento, as professoras puderam falar sobre diversos aspectos do acompanhamento. Inicialmente, elas falaram de como se sentiam preocupadas que a pesquisadora fosse apontar erros no trabalho delas, achavam que estava lá para corrigir algo, mesmo quando esclarecidas de que não se tratava disso.

Reconheceram que permaneceram distantes e desconfiadas da pesquisadora no início, mas, que passaram a gostar do acompanhamento e das conversas sobre as crianças.

Uma das educadoras mencionou que achava interessante, quando a pesquisadora chegava e, colocava os bebês que estavam chorando em volta de si e ficava brincado e conversando com eles. Percebia que eles se acalmavam e o choro diminuía. O que com o tempo elas passaram a fazer, pois quando a pesquisadora passava pela porta do berçário I, via uma delas sentadas com os bebês em volta.

Rosa emocionou-se ao perceber que ela cuidava mais e melhor dos bebês preferidos e que não se percebia capaz de cuidar de tanto bebês, o que a deixava triste.

Vânia mencionou que o acompanhamento a tinha feito perceber que ela não se relacionava com as crianças, que fazia os cuidados como se estivesse numa linha de produção, pois, muitas vezes, ela olhava para os bebês na sala e não sabia quem ela havia trocado, pois ela só olhava para o bumbum das crianças. Ela mencionou que com o acompanhamento passou a olhar os bebês nos olhos, conversar com eles enquanto realizava as trocas.

As educadoras também falaram sobre o momento de separação com os bebês. Diziam que o momento de transferência dos bebês de ciclo era muito difícil para elas. Pois não poderiam 
manter contato com as crianças, isso acarretava dificuldades de relacionamento entre elas. As educadoras achavam que atrapalhava a formação de vínculo dos bebês com as novas educadoras. Na ocasião, discutimos outras formas de fazer a transição e a importância da transferência dos vínculos para as novas educadoras, tendo em vista que, as antigas poderiam ajudar as novas, com informações sobre as crianças, mostrando o que sabiam e como eram as crianças, que havia espaço de relação para todas elas com os bebês.

As educadoras também revelaram que gostariam que o acompanhamento continuasse, que a pesquisadora continuasse auxiliando nas relações delas com os bebês e, também, nas relações entre elas mesmas e delas com a equipe técnica, pois sentiam que não tinham um acompanhamento e apoio ao trabalho por parte da instituição.

Essas colocações se encaminharam como propostas das educadoras para a equipe técnica da creche.

\section{A creche B}

A creche B foi acompanhada de maio à dezembro de 2013. Esta creche funciona como um Centro de Educação Infantil (CEI) em parceria com a Prefeitura Municipal de São Paulo, portanto conta com a supervisão da Secretaria Municipal de Educação. A creche possui capacidade para atender 133 crianças a partir do mês zero e podem permanecer até completarem três anos e onze meses de idade.

As matrículas podem ser efetuadas durante o ano todo, com maior incidência no mês de Dezembro. E o ingresso das crianças na creche ocorre sempre no mês de Fevereiro de cada ano. 


\section{O espaço}

Esta creche funciona em uma casa adaptada com salas para as crianças, refeitório, área externa e pátio e salas para administração da creche. Por ser uma casa, o espaço da creche é menor, as salas das diferentes turmas possuem um tamanho reduzido, sendo que as maiores salas são ocupadas pelas crianças em idade mais avançada.

Por ser uma casa em desnível em relação a rua, a casa possui um piso ao nível da rua (parte superior) e outros dois níveis inferiores acessados por escadas. A parte superior, fica distribuída entre a área administrativa da creche e as salas dos berçários e grupos de crianças menores, bem como, conta com um espaço amplo para atividades livres e TV. Nesse piso, há ainda uma pequena área aberta, chamada de solário, para onde as professoras levam os bebês para brincar e tomar sol.

Na parte inferior, localizam-se a sala da enfermagem, o refeitório, a cozinha o pátio externo e, um segundo nível inferior com outras salas para crianças de turmas maternais.

O refeitório era bem distribuído e comportava as crianças das diversas turmas para as refeições. Havia uma área com mesinhas e cadeirinhas para as crianças maiores e uma área com diversos cadeirões para os bebês.

O pátio externo contava com um espaço grande, com área verde e algumas árvores e canteiros de terra lateral. Havia alguns brinquedos disponíveis, como cavalinhos, triciclos, gangorras pequenas, balanços, gira-gira e escorredores, todos adaptados para os diferentes tamanhos e idades.

A sala do berçário era pequena e possuía um balcão para trocas dos bebês, um colchonete para acomodar as crianças, algumas cadeiras de balanço e um brinquedo pula-pula. Em uma das paredes, à altura e alcance das crianças havia um extenso cabide onde ficavam penduradas as bolsas e mochilas dos bebês. Também disponível havia duas caixas com diversos brinquedos à disposição das crianças, além de vários pequenos colchonetes individuais para o período de descanso. 


\section{A rotina da creche}

A creche funcionava com atendimento as crianças de segunda à sexta-feira, no período das $7 \mathrm{~h} 30$ às $17 \mathrm{~h} 15$. O grupo de crianças participantes da pesquisa, berçário, permanecia na creche em período integral.

As crianças eram acompanhadas por suas mães ou pais no momento de entrada e saída da creche. E as crianças eram recebidas na recepção ou portão da creche por funcionárias. Estas encaminhavam as crianças às respectivas salas.

O café da manhã era oferecido nas salas, por volta das $8 \mathrm{~h} 30$. Vinha servido em bandejas, com canecas plásticas com leite acompanhadas por pão, biscoito ou torradas. Havia também um intervalo para servir suco de frutas no meio da manhã.

As canecas eram entregues as crianças que sabiam tomar sozinhas, assim como os pães, biscoitos ou torradas. E, para aquelas que eram muito pequenas ou ainda não conseguiam segurar as professoras auxiliavam.

Na hora do almoço, as professoras auxiliadas por funcionárias volantes levavam os bebês para o refeitório. Os bebês eram acomodados nos cadeirões e recebiam os pratos de comida na mesinha dos mesmos. Alguns ensaiavam comer sozinhos, colocavam as mãos na comida, colocavam na boca, mas todos eram acompanhados e ajudados pelas professoras. Enquanto os menores eram alimentados pelas professoras, outras professoras e auxiliares também ajudavam nos cuidados com os bebês.

Depois do almoço havia o horário de descanso que acontecia entre as $12 \mathrm{~h} 00$ e $14 \mathrm{~h} 00$. Nesse período, as professoras pegavam os pequenos colchões no cantinho da sala, encapavam com lençóis e acomodavam os pequenos. Alguns dormiam e outros permaneciam acordados sob supervisão das professoras.

Na sala do berçário, próximo ao balcão de troca ficava um grande cesto de lixo com tampa de pedal. Alguns bebês ficavam curiosos e abriam com frequência a tampa do lixo e pegavam fraldas, lencinhos ou papéis sujos que eram descartados pelas educadoras.

Assim, nos momentos de troca, as educadoras precisavam estar atentas para os bebês que circulavam em torno delas, pois alguns além de mexer nos objetos do lixo, também os colocavam na boca. 
Observamos que para além do comportamento das crianças de mexerem no lixo, orientações sobre como realizar a higienização dos bebês e os descartes das fraldas eram com frequência mencionados pela técnica de enfermagem. Com o tempo, descobrimos, durante uma visita dos profissionais da vigilância sanitária à creche, que esses procedimentos eram recomendações e eram fiscalizados pelos agentes sanitários e o descumprimento motivo de notificação para a creche.

As visitas dos agentes sanitários eram preocupantes para as professoras, por ocasião da visita, elas ficavam tensas e pouco espontâneas. E, quando a visita acabava, elas riam e faziam piadas de si mesmas ao lembrarem do modo como se comportavam no decorrer da fiscalização.

Um desses procedimentos era envolver as fraldas usadas nas luvas plásticas descartáveis usadas pelas educadoras durante as trocas, o uso do álcool em gel, propés para entrar nas salas, nessa creche sem os calçados.

Nessa creche não soubemos dados sobre o período de adaptação porque as crianças ingressaram em fevereiro e não chegamos a acompanhar o momento de chegada dos bebês.

\section{As professoras e os bebês no berçário}

A turma do berçário era composta por 13 bebês e duas professoras fixas, além de contarem com a auxiliar volante para alguns momentos. Havia também uma voluntária que comparecia à creche todas as terças-feiras. Os bebês estavam em idade que variavam de sete meses a um ano e dez meses de idade no período que iniciamos a pesquisa na creche.

Logo na chegada à creche, chamou atenção como às professoras apresentaram as crianças. Elas foram chamando as crianças pelos nomes e contando algo de particular de cada uma delas. Algo assim, "este aqui é o Bruno é o mais simpático da turma e também nosso mordedor" ou "olha, esse é o Ivan nosso menino sorriso".

Elisa ao apresentar Carlos deixou evidente seu amor por ele, falando que o mesmo era seu xodó... Ao terminar de dizer, o abraçou e beijou! 
As crianças permaneciam a maior parte do tempo brincando e interagindo umas com as outras ou com as professoras. Apenas um garotinho chorava um pouco mais, pois havia ingressado há poucos dias na creche e, segundo as professoras, estava em fase de adaptação. Entretanto, nos momentos que ele chorava, as professoras o pegavam no colo ou traziam para perto delas e de outras crianças o que fazia cessar o choro.

Além dele, as professoras referiram que outra menina chorava como ele, mas que já estava mais adaptada e só chorava na hora da entrada na creche. As duas professoras demonstravam disponibilidade para estar com as crianças e, embora elas atendessem igualmente as solicitações de todas as crianças, logo ficou claro quais eram as preferências delas e das crianças.

Nessa creche havia uma programação pedagógica para desenvolver com as crianças. Dessa forma, era possível ver toda a semana alguma atividade em curso, seja para eventos da creche ou para aproximar as crianças de materiais gráficos como tintas, lápis de cor e papel e outros objetos.

Também aconteciam momentos de brincadeira com bolas, piscina de bolinhas, arcos, massagens etc., mas, os momentos que as crianças mais demonstravam interesse eram quando as professoras cantavam ou contavam histórias.

Toda a semana era possível ver as professoras cantando uma canção ${ }^{15}$ onde diziam os nomes deles, um a um, as professoras sentadas no chão ou colchonete, rodeadas pelos bebês, com alguns sentados ao lado, outros subindo no colo delas e disputando corpo a corpo, o corpo da professora, um lugar no colo ou mesmo a atenção mais particularizada, que aparecia em um abraço, em um beijo ou no "se jogar" dos bebês aos colos das professoras.

A hora da canção e da "contação" de histórias era sempre um momento onde os bebês ficavam reunidos com as professoras, todos atentos e prestando atenção ao que acontecia, pareciam mesmo gostar e relaxar nessas atividades, pois alguns chegavam a dormir.

Outra atividade que era mantida pelas professoras com as crianças era a música, as professoras colocavam músicas infantis e dançavam com as crianças. As crianças dançavam sozinhas, mas com o tempo, algumas delas formavam pares e dançavam juntas.

\footnotetext{
15 "Se eu fosse um peixinho

E soubesse nadar

Tirava o Marcos

Lá do fundo "do mar...".
} 
Nessa turma, as professoras conversavam bastante com as crianças, além de chamá-las pelos nomes, às vezes, colocavam apelidos carinhosos, chamando pela sílaba inicial do nome ou abreviando, por exemplo, Juliana, virava "Jú ou "Juju”. Nas crianças que estavam desenvolvendo a fala, essa forma de tratamento facilitava aprendizagem pelos próprios bebês, que passavam a chamar ou apontar uns aos outros pelos nomes. O mesmo se dava com os nomes das professoras, quando abreviados os bebês aprendiam e chamavam pelas professoras.

No entanto, algo que chamava atenção era a forma abrupta como as professoras acordavam os bebês, não havia nenhum tipo de preparação ou transição do sono para a vigília. As professoras pegavam os bebês que dormiam nas cadeirinhas ou ao colchonete no chão de forma inesperada para os bebês, elas pegavam e retiravam sem chamar, os bebês acordavam em sobressalto e sempre choravam muito.

Acordar os bebês para alguma necessidade da creche era algo comum, via-se isso em relação as trocas, aos períodos de brincadeiras no pátio, para o almoço etc. Às vezes, elas também acordavam os bebês para trocar as fraldas, desse mesmo modo abrupto, eles choravam durante toda a troca ou outras atividades.

Quando chegava a hora do almoço, as professoras desciam os bebês para o refeitório e todos sentavam em cadeirões, um ao lado do outro e à frente um do outro. As professoras colocavam os pratos diante de cada criança, os maiores eram incentivados a comerem sozinhos, sendo acompanhados e auxiliados quando necessário.

As trocas dos bebês aconteciam na própria sala do berçário. Durante as trocas, uma das professoras costumava conversar e brincar com as crianças, chamava os bebês pelos nomes, cantava pra eles, com alguns ela tinha brincadeiras particularizadas. Exemplo disso, era a troca de uma garotinha que a professora cantava uma musiquinha de um carrinho que vinha buscar a criança e buzinava para chamar, no momento do som da buzina, a professora enfatizava e esperava que a bebê completasse a música com o "bi-bi , bi-bi” da buzina. Uma graça!

Observava-se, no entanto, mesmo sendo a troca um momento de contato individualizado com as crianças, e este parecer agradável para ambos os parceiros, viu-se ao longo do tempo, que as trocas se tornavam automáticas e mecânicas, algumas vezes, era apenas mais uma das tarefas do dia-a-dia das professoras. 


\section{As relações na creche: professoras, equipe da creche e pesquisadora.}

A presente creche contou com o acompanhamento apenas dessa pesquisadora que foi recebida com disponibilidade pela equipe da creche e também pelas professoras. Como essa creche já havia participado da pesquisa no ano anterior, a equipe técnica da creche e as professoras estavam familiarizadas com o acompanhamento e demonstravam gostar das visitas semanais.

A equipe da creche era composta pela Diretora, uma coordenadora que prestava assistência à Diretora, uma assistente pedagógica, uma técnica de enfermagem, as professoras, cozinheiras e pessoal da limpeza.

Embora a dupla inicial de professoras que acompanhamos não tenha participado do acompanhamento anterior, elas demonstravam saber sobre a pesquisa e, após os esclarecimentos sobre as visitas de acompanhamento e os objetivos, se mostraram muito colaborativas.

Durante as visitas semanais nessa creche a pesquisadora abordava os bebês para brincar com eles, conhecê-los, observar a rotina de cuidados e conversar com as professoras sobre eles.

As professoras demonstravam gostar de conversar sobre as crianças, algumas vezes, contavam situações que envolviam o cotidiano dos bebês, outras vezes, elas falavam sobre aspectos que eram motivos de preocupação com eles, isso mostrava que as professoras sabiam sobre os bebês e pareciam interessadas neles.

Havia a técnica de enfermagem, pessoa chave na creche, pois ela sabia bastante sobre a creche e sua rotina, bem como, conhecia todas as crianças e oferecia muitas informações sobre elas. Além disso, era a pessoa responsável por organizar as reuniões da pesquisadora com as professoras, quando era necessário.

Era uma pessoa que prestava muita atenção às crianças e, às vezes, solicitava o acompanhamento de outras crianças da creche que despertavam preocupação ou apresentavamse mais difíceis de cuidar.

No que diz respeito à formação profissional das professoras, verificamos que a dupla inicial de professoras possuía formação universitária em Pedagogia. As professoras que vieram a substituí-las estavam em processo de formação, incentivadas pela creche como requisito para 
a continuidade na função de professor. Explicaram que a formação é uma exigência da secretaria municipal de educação.

\section{Sobre as mudanças na creche $B$}

Durante o período de observação acompanhamos sempre duas professoras cuidando dos bebês. No início do acompanhamento a dupla de professoras eram Elisa e Márcia ${ }^{16}$ e mantevese essa configuração até a metade do ano, porém a partir do segundo semestre, Márcia assumiu outro cargo disponível na creche e foi substituída por outra professora, Val que auxiliava o berçário como volante em alguns momentos.

Entretanto, no primeiro trimestre do segundo semestre, Elisa teve um problema de saúde e precisou ser afastada do trabalho com os bebês do berçário. Permaneceu trabalhando na creche e foi substituída por Val, que já havia substituído as professoras em Julho, período de férias.

Um fato que chamou nossa atenção a partir da troca de professoras foi o comportamento de morder dos bebês. Com a primeira dupla de professoras, a questão das mordidas figurava como problema a ser resolvido pelas professoras, uma vez que, as mordidas nos bebês causavam dificuldades diretas com os pais das crianças que se queixavam e reivindicavam providências da creche.

Elisa, a professora que se apresentava disponível no contato com os bebês era também a mais preocupada com a questão das mordidas. Bruno era, inicialmente, a criança identificada como mordedor, no entanto, com o tempo, outras crianças passaram a morder, multiplicando as situações e exigindo maior atenção das professoras.

Quando Elisa foi substituída por Val e assumiu a parceira com Márcia, a "epidemia" das mordidas cedeu. Observamos que Márcia não ficava tão aflita com as mordidas entre as crianças, embora, em todas as ocasiões, ela buscasse intervir.

\footnotetext{
${ }^{16}$ Os nomes são fictícios para não identificar as professoras e os bebês.
} 
Verificamos também que as crianças que mordiam (Bruno e Karina) eram crianças que gostavam muito de Elisa, assim como Carlos (bebê preferido de Elisa), que às vezes mordia, era um bebê que empurrava e batia nos demais, especialmente quando se aproximavam de Elisa.

Desta forma, a dupla de professoras foi totalmente substituída antes que o ano finalizasse, as professoras que assumiram o grupo de bebês pertenciam à creche e já eram em certa medida familiares as crianças.

Apesar das mudanças das professoras, o grupo de bebês permaneceu o mesmo do início ao fim do ano. A transição de professoras parece ter transcorrido sem provocar rupturas no comportamento dos bebês, pois observamos que as crianças não mostraram diferenças em seu modo de estar na creche ou efeitos que indicassem sofrimento.

$\mathrm{Na}$ reunião de encerramento com as professoras, elas falaram de todos os bebês, destacaram o que percebiam deles, as mudanças, os progressos e algumas preocupações que se mantinham com três crianças.

Uma garotinha que se mantinha sempre muito quietinha e de pouca interação com elas e com outras crianças e entendiam que elas precisavam continuar buscando por ela, facilitando as relações.

Outro bebê que tinha um acentuado entrave de domínio do corpo, o que nunca conseguimos saber o que era, pois a mãe dizia que os exames estavam sempre dentro da normalidade. Esse bebê chegou na creche aos 8 meses sem nenhum tônus muscular, era todo molinho e permanecia deitado o tempo todo. As profissionais foram acompanhando, pegando ao colo, ajudando a sentar, estimulando sempre o contato corporal e visual com ele. No final do acompanhamento, Murilo já se locomovia pela creche, não engatinhava, mas se arrastava e estavam ajudando ele a firmar-se em pé, o que com ajuda ele já conseguia.

Outro que preocupava as professoras era André. Um menino que as professoras diziam que a mãe negligenciava porque mandava para creche sempre sujo, sem banho, sem trocar as fraldas, com as roupas que a creche havia colocado no dia anterior. Isso gerava muita inquietação nas professoras. Especialmente em Maria, que dizia ter adotado André e falava: "ele é meu filho", dizia ficar muito sensibilizada com o abandono dele pela mãe.

Notaram que Bruno estava solicitando mais colo, estavam pensando que algo pudesse estar acontecendo na casa dele, pois ele estava mais sensível, chorava mais. 
Joana, a outra professora, falou sobre ser avó e como isso contribuía na relação com as crianças e falou sobre as conversas que realizamos sobre os bebês que a auxiliaram no cotidiano com eles.

\section{Os personagens das creches}

Participaram dessa pesquisa 24 (vinte e quatro) bebês de diferentes faixas etárias. Durante o acompanhamento, o bebê mais novo na creche contava com três meses de idade e os bebês com mais idade estavam com um ano e dois meses no momento inicial da pesquisa. A tabela abaixo mostra a distribuição dos bebês por faixa etária.

\section{Distribuição dos bebês por faixa etária}

\begin{tabular}{|c|c|}
\hline Faixa Etária & Quantidade \\
\hline 3 meses & 01 \\
\hline 4 meses & 02 \\
\hline 5 meses & 01 \\
\hline 6 meses & 03 \\
\hline 7 meses & 02 \\
\hline 8 meses & 01 \\
\hline 9 meses & 03 \\
\hline 10 meses & 04 \\
\hline 11 meses & 01 \\
\hline 1 ano & 02 \\
\hline 1 ano e 1 mês & 02 \\
\hline 1 ano e 2 meses & 02 \\
\hline
\end{tabular}

Notamos que a distribuição dos bebês por sexo se apresentou de forma uniforme, de maneira que acompanhamos igualmente o número de bebês meninas e meninos, mesmo não sendo essa uma preocupação de nosso estudo. 
Distribuição dos bebês por sexo

\begin{tabular}{|c|c|c|}
\hline Meninas & Meninos & Total \\
\hline 12 & 12 & 24 \\
\hline
\end{tabular}

O período de permanência das crianças na creche também se apresentou diferentes entre as creches $\mathrm{A}$ e $\mathrm{B}$, sendo que a creche $\mathrm{A}$ continha variações de horários internas.

Período de permanência dos bebês nas creches

\begin{tabular}{|c|c|c|}
\hline Horário & Número de horas por dia & Número de bebês \\
\hline $7 \mathrm{~h} 00$ às $16 \mathrm{~h} 00$ & $8 \mathrm{~h}$ & 05 \\
\hline $7 \mathrm{~h} 30$ às $17 \mathrm{~h} 15$ & $7 \mathrm{~h} 45 \mathrm{minutos}$ & 13 \\
\hline $8 \mathrm{~h} 00$ às $17 \mathrm{~h} 00$ & $8 \mathrm{~h}$ & 03 \\
\hline $12 \mathrm{~h} 00$ às $18 \mathrm{~h} 00$ & $6 \mathrm{~h}$ & 01 \\
\hline $13 \mathrm{~h} 00$ às $19 \mathrm{~h} 00$ & $6 \mathrm{~h}$ & 02 \\
\hline
\end{tabular}

Verificamos que havia diferenças em relação ao número de horas em que os bebês permaneciam nas creches. Mais uma vez, a creche A apresentou variações entre o número de horas em que as crianças permaneciam em seus cuidados.

Número de bebês e número de horas diárias na creche

\begin{tabular}{|c|c|}
\hline Número de horas diárias & Número de bebês \\
\hline 6 horas & 03 \\
\hline 8 horas & 21 \\
\hline
\end{tabular}

Importante dizer que dos 24 bebês, o acompanhamento diferiu para três bebês, sendo que um não foi possível acompanhar, pois permaneceu apenas duas semanas na creche, devido 
a problemas de saúde, a criança ficou afastada durante o período desta pesquisa. Outros dois bebês foram acompanhados um de março a setembro e outro de março a novembro de 2012.

Acompanhamos oito profissionais diretamente envolvidas nos cuidados dos bebês, todas do sexo feminino e com diferentes níveis de escolaridade e área de formação. Verificamos que uma das profissionais possuía Ensino Fundamental, três delas possuíam Ensino Médio, sendo uma com formação em Magistério e outra com formação Técnica em Enfermagem.

Encontramos quatro profissionais com Ensino Superior, sendo que três tinham formação na área da Pedagogia e uma em Psicologia.

Distribuição de profissionais por escolarização e área de formação

\begin{tabular}{|c|c|c|c|}
\hline Profissional & Idade & Grau de escolarização & Área de Formação \\
\hline A & 53 & Ensino Fundamental & Não possui \\
\hline B & 36 & Ensino Superior & Psicologia \\
\hline C & 40 & Ensino Médio & Magistério \\
\hline D & 33 & Ensino Superior & Pedagogia \\
\hline E & 58 & Ensino Médio & Técnica de Enfermagem \\
\hline F & 53 & Ensino Médio & Não possui \\
\hline G & 29 & Ensino Superior & Pedagogia \\
\hline H & 29 & Ensino Superior & Pedagogia \\
\hline
\end{tabular}

Com as profissionais o período de acompanhamento também mostrou variações. As profissionais $\mathrm{A}, \mathrm{B}, \mathrm{C}, \mathrm{D}, \mathrm{E}$ e $\mathrm{F}$ pertencem à creche $\mathrm{A}$ e as profissionais $\mathrm{G}$ e $\mathrm{H}$ pertencem à creche $B$.

As profissionais A, B, C e D foram acompanhadas durante o período que os bebês permaneceram no Berçário I, correspondendo ao período de março a novembro/2012. No momento da transferência dos bebês para o Berçário II as funcionárias E e F passaram a receber nosso acompanhamento, no período de junho de 2012 a março de 2013.

Em relação às profissionais $\mathrm{G}$ e $\mathrm{H}$, elas foram acompanhadas de maio a julho e de maio a setembro de 2013, respectivamente, sendo substituídas por outras funcionárias após esse período. 


\section{ANÁLISES}

\subsection{Os cenários de cuidados com os bebês nas creches}

A partir de agora, iremos descrever pequenos fragmentos de situações do cotidiano das creches envolvendo as profissionais e os bebês, que para efeito desse texto estamos chamando de cena.

Destacaremos algumas cenas para ilustração do modo como as relações de cuidados dos profissionais com os bebês foram se apresentando no contexto da creche e capturaram nosso olhar de diferentes modos, ora pela forma delicada e cuidadosa como se desenvolveram, ora pelo estranhamento que causaram a pesquisadora.

Pretendemos mostrar nas situações destacadas, especialmente, aquelas que causaram estranhamento algumas intervenções e como foram possíveis de serem realizadas pela pesquisadora.

Ainda, procuraremos mostrar que algumas dessas cenas foram se desdobrando no tempo e com o acompanhamento foram construindo pequenas histórias sobre os bebês e seus cuidados.

Apresentaremos as cenas e na sequência faremos a análise de cada uma delas, de modo, a manter o fluxo do texto e a compreensão de cada uma das cenas. Destacamos que todos os nomes e apelidos utilizados em nosso texto são fictícios, escolhidos aleatoriamente com objetivo de garantir a não-identificação dos sujeitos da pesquisa. 


\section{Cena 1: Camila e Paula}

Camila era educadora nova na creche, entrou no mês de junho substituindo uma educadora que solicitou demissão. Camila tinha uma filha com sete meses de idade que também estava na creche, porém, a bebê ficava no BII como norma da creche, que não permitia que as mães trabalhassem cuidando de seus bebês.

Paula ingressou na creche no mês de maio e contava com 5 meses e sua entrada contabilizava o número de 34 bebês no berçário I. Permanecia 8 horas diárias na creche e era acompanhada a maior parte do tempo por quatro educadoras.

Esta cena se dá aos seis meses de Paula. Ela estava em período de adaptação, portanto, a creche era novidade para bebê e educadora.

Paula chorava muito e parava apenas quando era atendida. Era um bebê que se acalmava ao colo. Seu choro era forte e alto, distinto entre os demais choros e identificado pelas educadoras, pois era tido por elas como irritante. O choro de Paula também vinha acompanhado de todo o corpo, pois ela esperneava e agitava os bracinhos também.

Minha impressão era de que, talvez, por irritar as educadoras, elas buscavam atender Paula quando o choro se estendia por um período longo.

Certa tarde, Paula dormia no bebê conforto quando sua mãe chegou para buscá-la. Camila aproximou-se dela e, em tom baixinho, chamou-a pelo nome. Depois foi tocando em seu corpo de forma delicada para que Paula despertasse aos poucos, sem pressa e sem susto.

Paula foi acordando devagar, em um ritmo de abrir e fechar os olhos, entre o dormir e o despertar. E, Camila permaneceu junto a bebê, aguardando que ela respondesse ao seu chamado. Somente depois deste pequeno ritual é que Paula fixou o olhar na educadora. 
Camila esperou pelo despertar de Paula, somente então, delicadamente, começou a realizar a transição de Paula do bebê conforto para seu colo. Iniciou a sustentação pelas costas dela, apoiando sua cabeça e trazendo todo o corpo apoiado e relaxado em direção ao seu colo.

E quando ao colo, a educadora envolveu-a e a aconchegou em seus braços. Para trocar a criança, deitou Paula cuidadosamente sobre o trocador, passou a verificar a fralda e todos os movimentos foram realizados de maneira suave, de forma a não perturbar o ritmo do bebê ao ser despertado de seu sono, proporcionando a transição entre o estado de sono e vigília. Paula permaneceu calma e parecia satisfeita.

Vejamos...

Começamos por traçar quem são os personagens de nossa cena. Primeiramente, a educadora, funcionária nova na creche, mãe de "primeira viagem" de um bebê que estava com 7 meses no momento que registramos essa cena.

A criança, um bebê que estava a quase um mês na creche, assim, em período de adaptação. Paula era um bebê que chorava muito, tinha um choro forte e alto que se destacava entre os demais choros na creche. Ela somente parava de chorar quando era atendida por uma das educadoras ou mantida ao colo. A ação de Paula era chorar forte e de corpo inteiro para ser atendida, ela parecia saber como chamar os cuidados que precisava.

Nessa cena, vemos Camila se aproximar de Paula no momento em que ela dormia. Camila começou a despertá-la mencionando seu nome em tom baixo e calmo, aos poucos e, de forma suave, tocando o corpo da criança. Nota-se que Camila mantém o som suave do chamado que desliza para o toque, também suave, ao corpo de Paula, mantendo um ritmo único entre sua fala e seu gesto.

Camila parece perceber a importância de estabelecer o contato com Paula de forma respeitosa, evitando uma quebra abrupta do sono da criança. Ela também se mostrava delicada ao propor um contato com a bebê, realizando gestos delicados, ritmados e que seguem respeitando o ritmo de Paula para transitar entre o sono e a vigília. 
A educadora se mantém chamando pelo nome e tocando delicadamente o corpo de Paula, aguardando os gestos de abrir e fechar os olhos do bebê. Camila permanece ali, junto com Paula entre o dormir e o acordar, até que a transição se complete e, Paula fixe os olhos na educadora.

Nota-se que a ação de pegar o bebê somente começa a ser realizada quando Paula se mostra em contato, quando ela se apresenta na situação fitando a educadora com seu olhar. Ela oferece os sinais para educadora com esse gesto, é a ação de Paula que direciona as próximas ações da educadora.

Camila parece ter esperado por este sinal antes de começar a retirar Paula do bebê conforto. A partir dessa comunicação entre elas, que a educadora vai apoiando o corpinho do bebê para sustentá-la ao colo. Aqui, vemos outro aspecto de Camila, a capacidade de esperar pelo sinal do bebê, a paciência e o respeito, ela aguarda pelo gesto do bebê. Há comunicação entre elas.

E ao colo, Camila envolve o corpo todo de Paula e aconchega em seus braços, mostrando que o segurar envolvente e firme sustenta a continuidade e o ritmo do bebê em seu despertar.

Camila continua com gestos delicados e ritmados ao apoiar o bebê no trocador. Todos os movimentos da educadora são suaves, o que permite que o ritmo de Paula se mantenha, o que parece atender as necessidades da criança, pois ela permanece tranquila, olhando fixamente a educadora enquanto ela limpa, troca a fralda, coloca as roupas.

Nota-se que todos esses cuidados foram realizados de forma envolvida e disponível, acolhendo o ritmo de transição do sono para o despertar do bebê. A educadora, que além de oferecer cuidados que respeitasse o ritmo da criança, os fez de forma delicada, atenta aos gestos do bebê e, principalmente, preservando o bebê de uma perturbação abrupta de seu descanso e relaxamento. Que pela resposta de Paula, ao continuar relaxada, calma e aparentando satisfação, nos indica que a educadora cuidou... 


\section{Cena 2: Mel, Roberto e Rosa}

Outra questão que fisgou meu olhar na creche foi o momento em que os bebês eram alimentados. Na hora das mamadeiras, os bebês eram acomodados nas cadeirinhas tipo bebê conforto, um ao lado do outro.

O que se via para a maioria das crianças, era a entrega, pelas educadoras, das mamadeiras nas mãos dos bebês. Os próprios bebês seguravam e tomavam suas mamadeiras sem auxílio das educadoras. Este procedimento acontecia mesmo com os bebês mais novos (quatro ou cinco meses) que não contavam com condições de sustentar suas próprias mamadeiras.

Nessas horas, às vezes, o grupo de educadoras ganhava reforço para auxiliar na alimentação dos bebês. Nessa época, novos bebês entraram no grupo e este somava agora 29 bebês.

Assim, nesse dia, outra educadora (Mel) se juntou ao grupo para ajudar. Mel alimentava Geovane (8 meses) e, às vezes, se dirigia à ele em tom de "bronca", pedindo que ele se comportasse.

Junto ao grupo, estava Roberto que iria completar 5 meses naquela semana. Esse bebê ingressou na creche em fevereiro aos 3 meses de idade e ficava um período de 8 horas diárias na creche. Era um menino muito sorridente e atento, a maior parte do tempo ele permanecia tranquilo, fazia parte do grupo dos bebês bonzinhos ${ }^{17}$.

Na sequência, Mel entregou uma mamadeira nas mãos de Roberto, que era induzido a tomar sua mamadeira sem auxílio da educadora, como outros bebês.

Mel falava com Roberto sobre sua preocupação com o mesmo tomar a mamadeira sozinho. Então, a educadora se dirigiu à criança e apoiou as duas mãos do bebê na mamadeira, de maneira a conduzir

\footnotetext{
${ }^{17}$ A esse respeito, ver o Capítulo O contexto das creches, item "Relações entre educadoras e bebês" - creche A.
} 
Roberto a segurar e levá-la à boca. Enquanto realizava essa ação, Mel conversava com ele e pedia que ele segurasse a mamadeira.

Como Roberto era pequeno e não conseguia segurar a mamadeira, a educadora decidiu então, fazer um pequeno rolinho com um forro de pano para revestimento das cadeirinhas bebê conforto e colocou-o sobre a barriga do bebê, abaixo da mamadeira, de forma a mantê-la suspensa e inclinada na posição possível para que Roberto pudesse sugá-la. E assim Roberto se alimentou...

Diante desse cenário, passei a participar da hora da alimentação dos bebês, auxiliando as educadoras na oferta das mamadeiras para os bebês. Procurava sentar ao lado das educadoras, escolhia e pegava os bebês menores ao colo e oferecia a mamadeira.

Enquanto essa tarefa era realizada, eu conversava com as educadoras sobre vários assuntos, elas falavam de acontecimentos pessoais, situações em família e, às vezes, falavam sobre os bebês.

Quando conversar sobre os bebês era possivel, procurava compreender o que elas sabiam sobre os bebês, como se chamavam, qual era o jeito de cada um etc. Com o tempo, as educadoras ajudavam a pesquisadora a alimentar os bebês, mostrando como eles gostavam de serem seguros ao colo, qual o bico de mamadeira mais gostavam, como poderiam ser acomodados após as mamadeiras, entre outras.

Ao longo do ano, notei que as educadoras passaram a pegar mais os bebês ao colo, principalmente, os bebês menores na hora da alimentação com as mamadeiras. Além disso, elas passaram a conversar também com os bebês e prestar atenção aos gestos em direção a elas.

Exemplar dessa novidade foi uma tarde em que fui chamada por Rosa ${ }^{18}$, na hora da mamadeira, para vê-la com uma menininha. E

\footnotetext{
${ }^{18}$ Rosa pertencia ao grupo de educadoras do berçário I. Era uma educadora que se apresentou bastante difícil no começo da pesquisa. Ela evitava o contato com a pesquisadora e, algumas vezes, posicionava-se de forma contrária às falas ou ações da pesquisadora. Uma ocasião, expressou-se para pesquisadora se referindo ao modo como conversava com os bebês durante o acompanhamento. Rosa disse que se irritava quando percebia que as pessoas mudavam o jeito de falar com as crianças, falando de um jeito infantilizado. Comentou que não gostava quando a neta mudava o tom de voz para solicitar algo à ela. E que não falava desse modo com as crianças. No momento
} 
educadora se dirigindo a mim, disse: "Quer ver uma coisa?" E se voltando para a bebê que estava à sua frente enunciou: "Fala: titia!" Soletrando "titia" de forma melódica e pausada. A bebê sorria e a educadora insistia repetindo o pedido. Então a bebê olhando para a Rosa disse: "titi"! Pronto! O rosto da educadora se iluminou de satisfação. Imaginem o meu!

Vemos alguns bebês em cena que ao chegar a hora da alimentação, são dispostos em cadeirinhas e recebem as mamadeiras em suas próprias mãos e os próprios as seguram e tomam suas mamadeiras sem auxílio de adultos, em sua maioria, esses bebês já eram capazes de fazer essa ação. Nota-se que não há contato corporal com os bebês durante a alimentação.

Porém, vimos Roberto, um bebê pequeno, sorridente e tranquilo, que pertencia ao grupo dos bebês "bonzinhos", por não solicitar muito os adultos ao seu redor, assim como, não ser de chorar e reclamar. E este menino não conseguia segurar sua própria mamadeira...

$\mathrm{Na}$ outra via, temos outra personagem, a educadora, que se apresenta disciplinadora, parece não demonstrar capacidade de esperar e acompanhar o ritmo dos bebês, aparentando revelar impaciência, irritação e hostilidade no contato com os bebês, especialmente, no caso de Geovane.

Mel, ao se dirigir à Roberto, mostra diferentes ações: a) entrega a mamadeira nas mãos de Roberto; b) fala com ele sobre sua preocupação em deixar que ele tome a mamadeira sozinho e c) induz Roberto a tomar a mamadeira.

Veja que a educadora fala de um estado de preocupação e, na sequência, ela busca a emancipação do bebê ao colocar a mamadeira nas mãos dele e direcionar para que ele levasse à própria boca.

Enquanto ela realizava essa ação, continuava conversando com Roberto para que ele segurasse a mamadeira. Sem sucesso, porque o bebê não conseguia segurar e derrubava a mamadeira. A ação de Mel, então, foi providenciar um tipo de apoio, que sustentado pelo corpo

em que esta cena acontece a pesquisadora já não se encontrava em acompanhamento no berçário I, foi apenas convidada a estar com a educadora, que mencionou sentir falta do acompanhamento pela pesquisadora. 
do bebê (barriga) permitisse que ele se alimentasse sozinho. Novamente, sem contato corporal com a educadora.

Assim, vemos um bebê sem recursos para suster uma mamadeira e alimentar-se sozinho, porque era pequeno para tal realização. E, junto a ele, um adulto que visa a emancipação do bebê, propondo ações e artifícios para que ele conquiste essa capacidade sem sua ajuda, não considerando o tempo, ritmo e a capacidade do bebê.

A educadora parece ver a não capacidade do bebê em segurar sua mamadeira e verbaliza sua preocupação, que ainda assim, não se revela suficiente para promover uma ação de ajuda à criança. A solução encontrada pela educadora é mantê-lo em sua incapacidade de se alimentar sozinho, a ação dela o mantém em desamparo.

O que acontece?

A educadora providencia um apoio para a mamadeira, emancipa o bebê e desconsidera as capacidades do bebê para segurar a mamadeira e se alimentar sozinho.

A situação parece apontar para o não reconhecimento da dependência em que se encontra esse bebê na relação com o adulto.

Tendo à frente esse cenário, a pesquisadora passa a fazer junto. Procurou a inserção na atividade de alimentação e, ao lado das educadoras, escolhia e segurava ao colo os bebês pequenos como Roberto para alimentá-los, segurando as mamadeiras para os bebês.

Essa intervenção, que não teve origem em palavras e, sim em gestos, foi sendo realizada em meio a várias conversas com as educadoras. Se poderia pensar em uma espécie de "drible". Enquanto fazíamos algo pelos bebês, falamos delas para chegar à eles.

Ao longo das conversas, que cada vez mais, se estendiam para os bebês, a ação das educadoras era ensinar à pesquisadora sobre os bebês, contar como era cada um deles, como aconchegar cada um, o jeito que cada um preferia ser alimentado, o tipo de mamadeira etc.

A posição da pesquisadora "no fazer junto" foi se deslocando daquela que mostrava ao fazer com elas, para aquela que passou a ser ensinada por elas. Portanto, vê-se que as ações da pesquisadora se pautaram no fazer junto e no conversar com elas sobre os bebês.

Como desdobramentos no tempo, notamos que os bebês pequenos, mas não só eles, passaram a receber mais colo. Ouvia-se mais conversas entre as educadoras e os bebês, elas notavam mais os gestos dos bebês direcionados à elas. E a tarefa de alimentação parecia mais leve e espontânea. 
Observamos isso em Rosa que fez o convite para ser acompanhada, alimentando e conversando com uma das crianças. Ela pareceu querer ser vista naquilo que fazia e via com a bebê.

A hora da alimentação pareceu se tornar um espaço para brincadeiras e trocas entre educadora e bebê. A dupla aparentava desfrutar uma da companhia da outra, ainda, notava-se em curso uma comunicação direta na brincadeira de Rosa com a bebê. Era clara a satisfação de Rosa ao ouvir o "titi" enunciado pela criança.

\section{Cena 3: Elisa e Márcio}

Márcio ingressou na creche em fevereiro, aos dez meses de idade, seu período diário de permanência na creche era de 8 horas. Ele compunha o grupo de 13 bebês do berçário e era acompanhado por duas professoras.

Essa cena se passou quando ele estava com um ano e um mês. Márcio era um garoto muito quieto, não solicitava as professoras, permanecia a maior parte do tempo sozinho e longe das outras crianças. Gostava de brincar com um carrinho específico, parecia o carrinho preferido por ele, brincava sempre sozinho, mas às vezes, olhava para as crianças para ver o que estavam fazendo. Márcio não se aproximava das crianças. Ele era silencioso, quase não falava, não chorava e não solicitava as professoras, mas sempre atendia a todas as orientações das mesmas, como sentar-se para tomar o suco, por exemplo.

Além disso, Márcio costumava ficar pelos cantinhos da sala. Havia um pula-pula que ficava em um dos cantos, ao fundo da sala, o lugar que Márcio gostava de ficar. Ele procurava esse espaço e parecia se esconder atrás do pula-pula. 
Em algumas visitas à creche, notei que Márcio repetia esse gesto. Então, um dia, professora e pesquisadora conversavam sobre as crianças e Márcio se pôs em seu cantinho. Diante disso, comentei com a professora que percebia que Márcio sempre procurava os cantinhos e que ficava sempre sozinho e mais distante dos outros bebês.

Elisa comentou que os bebês dessa idade não costumavam brincar juntos e que ela entendia que Márcio preferia crianças maiores, pois tinha um irmão mais velho e, além disso, notava que ele gostava de ficar na outra sala com as crianças mais velhas.

Na semana seguinte, Elisa e eu conversávamos sentadas ao chão, ao lado esquerdo da sala. Márcio estava a nossa frente e se espremia entre as cadeirinhas de balanço e a parede, mantendo apenas os olhinhos acima das cadeirinhas e nos mirava timidamente.

Comentei com Elisa que Márcio estava escondido atrás das cadeirinhas e nos olhava. A professora observou a criança e resolveu chamá-la para se juntar a nós. Márcio não atendeu à solicitação da professora. Assim, Elisa se levantou e foi até ele, pegou-o no colo e trouxe para perto de nós duas.

Elisa iniciou um jogo entre ela, Márcio e eu, aproximando-o e afastando-o de mim, até que o colocou em meu colo. Márcio sorriu durante a brincadeira, quando foi colocado ao colo, rapidamente procurou descer e se afastou. Terminada essa brincadeira e vendo a reação dele, a professora comentou que notava que Márcio estava triste e que algo poderia estar acontecendo com ele.

Aproximadamente duas visitas depois, algo interessante aconteceu. Nesse dia, o grupo de bebês estava completo e as crianças estavam brincando com as professoras. A técnica de enfermagem se juntou ao grupo, brincou com as crianças, conversou com as professoras e se retirou da sala. Passou algum tempo e Elisa notou a ausência de Márcio.

Diante disso, as duas professoras ficaram muito preocupadas com o desaparecimento do bebê. Assim, Elisa saiu apressadamente da 
sala à procura de Márcio. Alguns minutos depois, Elisa retornou com Márcio nos braços, apertando-o em abraços, beijando e fazendo cócegas na barriga dele. Márcio pareceu gostar muito da brincadeira.

Elisa descobriu que a técnica de enfermagem saiu com Márcio da sala e a professora da turma maternal (Maria), que gostava muito dele, ficou com ele em sua sala. Nas semanas seguintes, ouvia-se mais o nome de Márcio na sala e a criança passou a solicitar mais das professoras, chorava quando algo o incomodava, ele ficava mais perto das outras crianças, às vezes, até disputava brinquedos com elas. Márcio não foi mais visto pelos cantinhos...

Márcio era silêncio, quietude, ficava sozinho, brincava sozinho e ficava pelos cantinhos. Era uma criança já adaptada à creche, parecia conhecer a rotina da creche e atendia às orientações das professoras.

Ele não solicitava ajuda, estava no grupo e distante das demais crianças. Ele gostava de um único brinquedo, um carrinho, seu brinquedo preferido. Márcio também se mostrava atento e curioso à sua volta, ele olhava o que os outros faziam, mas parecia se esconder...

Elisa, a professora, era disponível e atenta ao grupo de bebês. Ela parecia saber falar sobre Márcio e demonstrava conhecer um pouco da história dele e de seu jeito.

Quando a pesquisadora realizou a primeira conversa sobre Márcio com Elisa e apontou que ele ficava pelos cantinhos, ela pareceu não ter percebido que isso acontecia. E, ofereceu à primeira vista, uma explicação que se direcionou mais para o âmbito técnico-científico (teorias pedagógicas, de desenvolvimento infantil etc.), pois: "crianças dessa idade não brincam juntas". Inicialmente, não falou sobre Márcio...

Ao mesmo tempo, se Elisa, mesmo que ligeiramente tivesse notado que, Márcio ficava pelos cantinhos, ela por sua vez, ainda não havia esboçado nenhuma ação na direção desse ato de Márcio.

Porém, ressalta-se que ao continuar a conversa, Elisa completou com os conhecimentos que ela tinha de Márcio. Quais? Que ele preferia crianças maiores, que ele tinha um irmão mais 
velho e isso parecia influenciar nessa escolha, ela notava que ele gostava de ficar na turma de crianças mais velhas e coisa e tal. Aqui, começa a falar sobre a criança.

Embora Elisa parecesse não ter visto que Márcio ficava pelos cantinhos e também não soubesse dizer mais sobre o fato, ela mostrou que tinha os olhos voltados para Márcio, que ela conhecia aspectos da história e do jeito de ser dele e, acima de tudo, Elisa se apresentou disponível para a criança e para nossas conversas sobre ele.

A cena avança ao ponto que a professora e pesquisadora conversavam sobre as crianças e a pesquisadora nota Márcio escondido atrás das cadeirinhas, olhando para as duas. A pesquisadora comenta com Elisa sobre Márcio e ela o vê no cantinho e parecendo se esconder.

Márcio realiza a ação de olhar para os dois adultos, ele mostrava se manter em contato com elas...

É nesse ponto que, Elisa passa a chamar por Márcio, primeiro o chamou pelo nome, depois fez um gesto para que ele se aproximasse. Ele não atendeu. Elisa foi até ele, pegou-o no colo e o trouxe para perto. Propôs uma brincadeira entre ela, ele e a pesquisadora. Um jogo de aproximar e afastar Márcio dela e da pesquisadora. Note-se que o jogo é aproximar e afastar ele.... Ora, de uma, ora de outra!

Pode-se levantar a hipótese de que Márcio ao parecer esconder-se fazia tentativas de atrair a professora e a pesquisadora, talvez, uma forma de brincar. O que se deu pela ação da professora e o jogo entre ela e a pesquisadora com Márcio!

A brincadeira termina quando a professora coloca Márcio no colo da pesquisadora, ao que ele, rapidamente desce e se afasta. É nessa hora que Elisa comenta que notava que Márcio poderia estar triste, algo poderia estar acontecendo. Novamente, Elisa fala de Márcio, agora, após brincar com ele, ela estava com ele.

Parece que depois do contato com Márcio, dos instantes de acompanhamento dele, o olhar de Elisa para Márcio começa a se alterar...

Vem então, o "sequestro de Márcio" pela técnica de enfermagem. Nessa hora, as duas professoras estavam brincando com as crianças e não notaram a retirada de Márcio. Elisa nota a ausência de Márcio e demonstra preocupação. A ação dela é sair à procura dele e voltar com ele nos braços. Ela volta brincando com ele, apertando-o em abraços, beijos e cócegas. E Márcio? Pareceu se divertir com a brincadeira. 
Márcio ganhou um espaço de visibilidade, sua existência agora estava contemplada pela professora, seu nome era agora dito, evocado! A ação de Márcio se ampliou, ele passou também solicitar as professoras, chorava quando algo o incomodava, ele passou a sentar mais perto das outras crianças, também podia disputar brinquedos e criar atritos.

As ações de Márcio passaram a ser solicitar mais os adultos, chorar, ficar mais próximo das crianças, disputar e brigar com elas por brinquedos.

Poderia se olhar para a busca pelos cantinhos e o brincar sozinho desse menino como sinal de isolamento, no entanto, ao notar que ele olhava ao seu redor, ele respondia as solicitações das professoras, compreendeu-se que o olhar dele para o que acontecia a sua volta o situava no grupo, mostrava que ele estava no grupo, mesmo quando nos cantinhos, seu olhar se dirigia para as pessoas que ali estavam com ele. Esse também é o Márcio.

O jogo de Márcio era esconder e aparecer... pelos cantinhos! Ao que parece, ele foi resgatado dos cantinhos, foi de lá retirado.

\section{Cena 4: Vânia, Amanda e Raimunda}

Amanda ingressou na creche aos 4 meses de idade. Conheci-a no mês de março, quando ela estava com 5 meses, ficava diariamente por 8 horas na creche. Fazia parte de um grupo com 30 bebês no berçário $I$.

Amanda era um bebê muito quieto e chorava muito baixinho, seu choro era fraco e lembrava mais um chiado. Ela era pouco notada na creche e pertencia ao grupo dos bebês invisíveis ${ }^{19}$. E as educadoras pareciam não contar com a presença dela, diversas vezes ela permanecia chorando no berço ou no colchonete sem nenhum auxílio de adultos.

\footnotetext{
${ }^{19}$ Sobre isso, ver Capítulo $\mathbf{O}$ contexto das creches, item "Relações entre educadoras e bebês" - creche A.
} 
Em algumas ocasiões encontrei-a deitada de bruços com o rosto colado ao colchão ou colchonete, aparentemente, sem conseguir sair dessa posição, notava pequenas pocinhas de choro que se formavam...

Nesses momentos, eu a trocava de posição, conversava com ela, inseria alguns brinquedos. Quando ela estava chorando, acariciava-a e comecei a notar que ela olhava para minha mão, para meu relógio, ora tentava segurá-lo. Ela não me olhava ${ }^{20}$. Era preciso insistir durante um tempo até que uma pequena troca de olhar acontecesse, algo que logo desvanecia.

Amanda também não costumava reagir quando chamava por seu nome ${ }^{21}$, parecia não ouvir e, também notava que ela chupava dois dedinhos (indicador e médio) e parecia entrar em um estado de completo desligamento, nenhum contato com ela se estabelecia, ela parecia isolada em si mesmo. Em outros momentos, ela realizava uma espécie de balanço, ficava em posição de gatinho e se balançava para frente e para trás, incansável.

Comecei a conversar sobre Amanda com uma das educadoras, além de procurar um contato com a criança em todas as visitas. Nas semanas seguintes, observei que Amanda pareceu estabelecer um pouquinho mais de contato, passou a olhar quando eu chamava. Chorava menos e estava mais interessada em brinquedos, em uma

\footnotetext{
${ }^{20}$ Nesse ponto, fazemos um destaque para mostrar como os estudos e referências dos aportes teóricos podem instrumentar o olhar do pesquisador. Aqui, a pesquisadora enfatiza a questão do olhar do bebê, pois como participante da pesquisa IRDI, naquele momento estava atenta a leitura dos indicadores que poderiam sinalizar para risco precoce de autismo, o que marcou o olhar para esta cena. O não olhar ou evitamento do olhar em bebês e crianças pequenas pode ser um indicador precoce para sinais de autismo. Para saber mais sobre os indicadores (IRDIs) e sobre essa pesquisa, ver (KUPFER et al., 2003), (KUPFER; BERNARDINO; MARIOTTO, 2012) e (KUPFER; BERNARDINO; MARIOTTO, 2014).

${ }^{21}$ Destacamos dois estudos que tratam do reconhecimento do próprio nome por bebês. Em um estudo intitulado "Desenvolvimento de bebês nascidos pré-termo no primeiro ano de vida", os pesquisadores apresentam uma escala brasileira utilizada para avaliar o Desenvolvimento do Comportamento da Criança - o primeiro ano de vida (EDCC), nessa escala consta como item esperado para bebês aos 6 meses de idade "virar-se quando chamado pelo nome" (LINHARES, 2003).

E, há também um estudo piloto realizado por fonoaudiólogos brasileiros com 16 bebês de quatro a cinco meses de idade que aponta, embora a maior parte da literatura existente indique que o reconhecimento do próprio nome por bebês possa ocorrer entre 6 a 9 meses, discutem que nenhuma delas mostra estudos empíricos que suportem os indicadores. Este estudo brasileiro revelou que bebês aos quatro e cinco meses de idade podem reconhecer o próprio nome. Como critérios deste estudo, os pesquisadores consideraram o deslocamento da cabeça e do olhar em direção à fonte sonora, o tempo de permanência do olhar e a atenção às evocações (MACHADO et al., 2013).
} 
ocasião consegui ver um sorriso dela quando a mãe chegou para buscá-la.

Essa criança apresentava um acentuado estrabismo em um dos olhos. E em uma das conversas com Vânia (educadora), esta contou que havia conversado com a mãe da criança por ocasião de um vídeo feito para o dia das mães. Nesse vídeo, havia um close de Amanda recebendo massagem de uma das educadoras em que ela aparecia frontalmente, olhando para o vídeo. Vânia relata que a mãe ficou muito emocionada e agradecida. Na ocasião também conversaram sobre o problema visual de Amanda, pois a mãe tinha dúvidas se a filha enxergava bem. A educadora disse à mãe que notava que Amanda enxergava sim, o que a tranquilizou, segundo Vânia.

Após essas conversas com a Vânia, notei que Amanda passou a receber mais atenção, em diferentes momentos, a educadora procurava atender a criança, especialmente quando chorava. Também foi possível ver a educadora ninando Amanda para dormir.

Falei com a educadora sobre a percepção de que Amanda era uma criança que sorria pouco e que não olhava muito para as pessoas. Vânia contou que no ingresso da criança na creche notava isso e se preocupava, mas que naquele momento via que Amanda já sorria para elas quando chegava à creche com a mãe e, que a criança olhava mais para ela e uma outra educadora, porém ela não observava o mesmo com as demais educadoras.

Numa das visitas, Vânia estava com Amanda ao colo, notei Amanda olhando para Vânia. Fiz uma aproximação das duas e Amanda resmungou quando tentei conversar com Vânia. A criança pareceu demonstrar não lhe ter agradado a minha aproximação, no momento em que Vânia a ninava.

Depois disso, Amanda dormiu um sono curto e acordou chorando. Ela voltou para o chão e os brinquedos, mas continuou chorando por algum tempo. Aproximei-me e, depois de algumas 
tentativas, encontramos uma posição em meu colo em que ela ficou mais tranquila e dormiu novamente.

Minha impressão era de que Amanda parecia querer algo, ela chorava e não era fácil compreender o que precisava e se ressentia quando não acontecia.

Ao conversar com Vânia sobre sono na creche, porém, a educadora mencionou que Amanda gostava de silêncio para dormir e ficava atenta quando havia muito barulho ao seu redor. Também contou que o sono dela era leve e sempre curto, mas que antes a criança não dormia na creche, o sono era algo novo no repertório de Amanda na creche.

Passei a ver Amanda explorando a sala, se locomovendo e ficando próxima a grade de entrada onde ficavam as educadoras. Até aqui parecia que algo estava acontecendo...

Notei que os balanceios de Amanda estavam cessando, colocava menos os dedinhos na boca e passou a chorar com mais força!

Em Junho, houve uma mudança. Alguns bebês foram transferidos do Berçário I para o Berçário II, o que implicou em troca de educadoras. Amanda estava entra elas e contava com 7 meses de idade.

Houve um pequeno período de recesso entre junho e julho. Em uma tarde quando voltei a creche para a vista, fiquei sabendo da mudança. Sendo assim, fui conhecer a nova sala $e$ as novas educadoras. Ao chegar, apenas uma delas se encontrava na sala, era uma substituta. Estava com as crianças no centro da sala, tentei aproximação, uma conversa falando sobre alguns bebês, ficamos juntas e brincamos com os bebês.

Algumas crianças se aproximaram com brinquedos e brincamos juntos por algum tempo. Enquanto isso, procurava localizar Amanda entre elas, então a vi engatinhando em minha direção. Ao perceber que eu a tinha visto, Amanda esboçou um sorriso. Como eu estava ao chão, ela "apressou o passo" e vocalizou com ar de alegria, subiu no meu 
colo com um grande sorriso. Brinquei com ela, segurando e apertandoa no colo e ela dava gargalhadas. Foi a primeira vez que um contato dessa ordem aconteceu.

Na semana seguinte, conheci a educadora que estava ausente, Raimunda. Ela estava sentada no centro da sala com os bebês, sentei ao chão junto com elas. Raimunda não se mostrou receptiva a minha presença. Tentei conversar com ela, nas vezes que ela respondeu foi quase monossilábica (respondia sim ou não), não mantinha a conversa e, outras vezes ignorava minha fala. Tentei falar sobre os bebês, também não foi possível.

Aos poucos a educadora se distanciou e deixou os bebês, estes se aproximaram de onde eu estava. Ela somente retornou para o centro da sala, quando ocorreu uma "disputa de fraldas" entre dois deles. Tentei mediar a situação entre os bebês, indo ao encontro deles, mas rapidamente a educadora retirou e isolou Mariana (a bebê envolvida na disputa) que chorava por ter tido a fralda arrancada por Gustavo. Raimunda pegou Mariana e a colocou sozinha em uma cadeirinha do outro lado da sala e a criança permaneceu chorando com a educadora falando em tom alto e enérgico com ela.

Permaneci observando a cena, assustada com o que estava vendo. Nesse intervalo, Amanda me avistou sentada junto às crianças, engatinhou e subiu no meu colo. Tentei fazer com se interessasse pelos brinquedos, mas não funcionou. Colocou os dedinhos na boca e entrou em seu desligamento de contato. Fiz algumas brincadeiras com ela, percorrendo o corpinho dela com meus dedos, indo dos pés à barriga, chegando nas mãozinhas dela ao que ela tirou os dedos da boca e começou uma interação.

Ao tentar tirá-la do colo, recomeçou a chorar. Eu temendo que ocorresse o mesmo com ela permiti que ficasse um pouco mais em meu colo. No entanto, quando foi necessário tirá-la, porque era hora que eu iria embora, Amanda chorou muito. Fui conversando e tentando oferecer alternativas (brinquedos) para que ela se acalmasse, porém, a educadora não permitiu que eu continuasse e retirou Amanda, 
colocando-a no berço, repetindo o mesmo tom alto, áspero e enérgico com ela.

Amanda chorou por um longo tempo e olhava do berço em minha direção. Ela parou de chorar e começou o balanço engatinhada no berço, de modo que o berço se movia para frente e para trás. Ela continuava me olhando do berço. Exausta pelo balanço, ela adormeceu... (Nessa época, Amanda estava com 8 meses).

Não consegui me mexer, fiquei sem saber o que fazer, diante da maneira como Raimunda conduziu a situação, saí da visita pensando...

\section{Quem era Amanda?}

Uma menina aos 5 meses de idade, quieta, que chorava baixinho. A ação de Amanda era chorar baixinho, chiar. Parecia frágil, corporalmente se mostrava frágil, sem condições aparentes de se mover, parecia não ter forças para isso. Permanecia na posição que a colocassem.

Amanda fazia parte de um contexto de creche em que ela permanecia, diariamente por 8 horas. Nesse cenário, Amanda era pouco notada, as educadoras pareciam não contar com a presença dela, diversas vezes, ela permanecia chorando no berço ou nos colchonetes ao chão sem nenhum auxílio de adultos.

Quem eram as educadoras?

Adultos que não viam, aparentavam não notar a presença de Amanda, não auxiliavam. O adulto vai aparecendo pela ausência...

Nesse cenário, víamos se desenhar por um lado, Amanda, como uma espécie de traços de sons fracos e, educadoras que não ouviam, não notavam a presença e não auxiliavam.

O que víamos?

Amanda em sua ação. Ela continuava chorando no berço ou no colchonete, chorando quietinha, baixinho, fraquinho e formando pocinhas de choro, sem se mover... 
Parecia que os sons fracos de Amanda se estendiam para o corpo, essa fraqueza de sons era vista também na falta de força corporal para se mover, sair da posição em que estava não parecia possível.

Amanda chorava com lágrimas! Lágrimas nesse cenário diziam muito, elas diziam dos recursos de Amanda, para além do sofrimento que expressavam, elas comunicavam que algo estava acontecendo, ela parecia precisar de algo, as lágrimas eram, também, sinal de que Amanda estava viva e tinha esperança.

As lágrimas mostravam que Amanda estava imersa no desamparo, além disso, essas mesmas lágrimas que formavam "pocinhas" indicavam o tempo que passava e, principalmente, denunciavam a ausência do adulto.

Verificava-se que Amanda parecia não reagir aos chamados. Era comum ela colocar dois dedinhos na boca e chupar, ficava em uma espécie de desligamento do ambiente, o que parecia distanciá-la ainda mais do contato. Em outros momentos, ela ficava em posição de "gatinho", apoiada sobre os bracinhos e perninhas e se balançava para frente e para trás por longos períodos.

Esses comportamentos autoestimulatórios pareciam sinalizar a ausência de contato com essa criança. Esses gestos nos levam a pensar que, Amanda, através deles, procurava manter um contato com o próprio corpo, talvez ela quisesse proporcionar a si mesma algo que lhe faltava nesse ambiente. Como se fosse uma espécie de tentativa de resgatar ou manter algo que ela precisava.

Lembrando que Amanda era um bebê com apenas um mês na creche, um período considerado de adaptação e, o que se via era uma criança que não parecia ser ajudada em sua adaptação. Ela estava sozinha e parecia apenas contar com seus próprios recursos, que evidentemente, não eram muitos e se apresentavam mais frágeis.

Nesse momento que entra outro personagem, outro adulto, no caso a pesquisadora que se aproxima de Amanda. Ao se aproximar trocava ela de posição, conversava com ela, a acariciava, trazia alguns brinquedos.

E o que foi acontecendo?

Amanda começou a responder à aproximação desse outro adulto. Ela fazia gestos que indicavam que ela estava estabelecendo um contato com a pesquisadora. Pois, Amanda olhava para a mão que a acariciava, olhava o relógio que brilhava à frente dela, fazia tentativas de 
agarrá-lo. Ela estava mostrando interesse no ambiente, ela estava se direcionando em busca de algo. Ela estava lá e viva!

As trocas de posição realizadas para Amanda, também poderiam ser experienciadas como alívio, pois a impressão era de que ela ficava muito tempo na mesma posição, ainda, a mudança de posição e o toque da pesquisadora facilitariam o contato dela com o próprio corpo e com o ambiente.

Ao buscar o contato com Amanda em todas as visitas e oferecer esses mesmos cuidados, criou-se uma regularidade no contato, pois sempre a mesma pessoa, com o mesmo jeito, mesmo ritmo, os mesmos gestos, atendendo as necessidades que Amanda pudesse expressar. Essas regularidades e continuidades ao longo das semanas foram possibilitando que entre ela e a pesquisadora, se formasse uma relação, que primeiramente, se deu em forma de contato.

Nota-se que nessa relação de continuidade pelas visitas, Amanda foi formando alguns sinais desse contato, que fossem sensações e/ou imagens, ela estava registrando uma memória da presença da pesquisadora, que passava pelo corpo dela, pelo corpo da pesquisadora e pelas sensações que eram experimentadas nesse contato.

A partir disso, podemos sinalizar que uma relação de cuidados começou a se formar, pois a criança passou a dar sinais de reconhecimento da pesquisadora, fez gestos na direção dela. E mais, Amanda foi conservando a presença da pesquisadora em si mesma, pois era capaz de lembrar-se da pesquisadora no intervalo de uma semana.

Destaca-se que os contatos com Amanda e a pesquisadora se diferenciavam do contato com as educadoras, pois esses eram marcados por trocas de fraldas, alimentação e outros cuidados. Um contato que não fosse desse tipo, parecia bastante raro nesse cenário.

E as ações da pesquisadora nesse cenário?

A primeira ação foi a aproximação com uma das educadoras, para construir um espaço com ela para a realização de muitas conversas sobre Amanda. E, a partir dessas conversas a pesquisadora procurava conhecer e saber de Amanda junto à educadora.

A partir daí, pareceu começar se abrir um espaço para conversas sobre a criança entre a pesquisadora e a educadora. Além disso, apareceram conversas entre a educadora e a mãe da criança, os diálogos sobre Amanda se multiplicaram, se expandiram. Amanda foi virando assunto... Ela foi sendo identificada! 
Amanda passou a ser mais falada na creche, foi sendo mais vista, apareceu o vídeo da massagem com um close dela, as pessoas comentavam o fato, a mãe da criança deu sinais de gratidão. A professora pareceu satisfeita.

Começa o desmonte da invisibilidade de Amanda na creche.

Ressalta-se que com o avanço das conversas com a educadora, a pesquisadora passou a apontar aspectos que não observava em Amanda, olhando e mostrando o que faltava. Pode-se pensar que esse modo de abordagem da pesquisadora estava falando em detrimento da criança, talvez, um outro observador ressaltaria o que Amanda apresentava.

E, o interessante é, que frente à isso, Vânia foi mostrando seu conhecimento de Amanda, ao mesmo tempo que, cada vez mais, voltava o olhar para a criança. Ao destacar o que a criança possuía, a educadora também apresentava elementos que apontavam outros aspectos da criança e também ampliaram a compreensão da pesquisadora sobre Amanda.

Vejamos...

Ao apontar que Amanda "sorria pouco e não olhava muito para as pessoas". A educadora completou que notava isso no começo e destacou que: "naquele momento via que Amanda já sorria para elas quando chegava à creche com a mãe e, que a criança olhava mais para ela e uma outra educadora. Porém, ela não observava o mesmo com as demais educadoras".

Aqui, a educadora chamou atenção para o olhar diferenciado que Amanda apresentava, provavelmente, para as pessoas que lhe dirigiam um olhar e maior cuidado. Amanda parecia olhar para quem a olhava. Era um olhar discriminado da criança para os adultos que dela cuidavam.

Vânia apresentou um olhar diferenciado da pesquisadora, ampliando a percepção desta da criança. No mesmo golpe, mostrou-se ligada à criança, estava mostrando que sabia algo sobre Amanda, que a notava, a olhava, a acompanhava e guardava a história de Amanda na creche.

Com as conversas entre pesquisadora e educadora e os contatos semanais da pesquisadora com a criança, notou-se que algo foi acontecendo com Amanda. Ela passou a olhar quando a pesquisadora chamava, chorava menos e estava se interessando por brinquedos, também apareceu sorrindo. Amanda estava mais presente. 
Observou-se movimentos na educadora e desta na direção da criança. Vânia passou a buscar mais o choro de Amanda, sim, porque lembramos que o choro dela era um conjunto de sons fracos, chiados... Vânia passou a ouvir mais, olhar mais para Amanda.

Viu-se que Vânia passou a ninar Amanda para dormir, que entre elas havia trocas, lá estavam os olhares de Amanda para Vânia, olhares entre elas. Havia mais do que olhares em jogo, uma comunicação se instalou, parecia que uma relação de cuidados estava em curso. Evidência disso, era a expressão de desagrado da criança com aproximação da pesquisadora, no momento de intimidade entre elas.

Nas conversas sobre o sono de Amanda, novamente Vânia mostrava como, cada dia mais, conhecia a criança e oferecia notícias de como era o sono, como ela gostava de ser ninada, que era de silêncio que Amanda precisava etc.

As conversas continuavam circulando entre educadora e a pesquisadora. As atenções da Vânia pareciam se dirigir para a criança. Amanda virou o centro das conversações e das ações!

Uma transição do olhar e dos cuidados da pesquisadora que, na circulação das conversas e na relação que se constituiu entre os adultos em questão, foi desenvolvida e incorporada pela educadora, que passou a olhar mais e a cuidar de Amanda.

\section{E Amanda?}

Amanda estava mais presente no espaço, podia fazer mais uso dos objetos e pessoas. Ela explorava a sala, se movimentava, buscava pela educadora na grade que dividia o berçário. Seus gestos autoestimulatórios diminuíram e seu choro aumentou, ou melhor, ganhou força, se tornou forte e audível na sala. Amanda estava se comunicando, parecia outra criança.

O que Amanda conquistou?

Corpo! Ela ganhou corporeidade. Os cuidados com o corpo, ser trocada de posição, ser tocada, segurada ao colo, ninada, receber conversas e olhares direcionados pessoalmente para ela, configuravam a presença de Amanda.

Ser vista e ver as pessoas, ser tocada e tocar as pessoas, ser ouvida e ouvir as pessoas são gestos e ações que compuseram o ambiente dela, proporcionaram a existência corporal da criança na creche.

A reunião dos traços de sons fracos e baixinhos com o corpinho frágil, molinho, aparentemente desprovido de força e condições de se articular para criar movimento, teve início com o amparo oferecido, primeiramente pela pesquisadora, que ao ser ampliado e encampado 
pela educadora obteve continuidade, ganhando a circularidade dos braços de Vânia, bem como sua sustentação.

Por essas conversas e ações abriu-se um espaço para a introdução da criança. Inaugurouse um espaço de visibilidade para Amanda na creche, criou-se um espaço para a existência de Amanda nesse cenário.

Vimos se abrir um espaço de existência para Amanda e juntamente com ele vieram cuidados que pareciam corresponder as necessidades da criança. Diante disso, pudemos notar o desabrochar de Amanda... A bebê estava substituindo os comportamentos autoestimulatórios por relações de troca e comunicação com outras pessoas.

Nesse caminho, o entrelaçamento de relações entre Amanda, Vânia e a pesquisadora, proporcionaram a tessitura de um quadro de cuidados, pois as três personagens mostraram seus gestos e suas ações em diferentes direções. Esses gestos encontraram ressonância e alcançaram como resultado a construção de cuidados simples, básicos e fundamentais para o desenvolvimento psíquico de Amanda.

Agora, o cenário que se desenhou sofreu alterações com a mudança de Amanda para a sala do berçário II onde a criança passou aos "cuidados" de outra educadora, um momento de ruptura nas relações de cuidados recém estabelecidas entre Amanda e Vânia.

Logo na primeira visita de acompanhamento da pesquisadora ao BII, a ação da pesquisadora foi aproximar-se da educadora substituta, conversar com ela, saber sobre as crianças, parecia haver a possibilidade de estabelecer uma relação e um trabalho em conjunto.

Amanda demonstrou reconhecer a pesquisadora, revelando sua memória afetiva, mostrando que ela mantinha os registros de uma relação com a pesquisadora. Ela se aproximou, vocalizou e fez um apelo para ir ao colo. Então, peguei, apertei-a no colo, ela ria, brincamos juntas e ela parecia satisfeita. Ela revelava continuar podendo usufruir da presença e relação com um adulto.

Contudo, na semana que se seguiu, Raimunda, a educadora da sala que estava ausente na primeira visita, retornou a seu posto.

Quem era Raimunda?

Era dureza, ira, hostilidade.

As ações da pesquisadora continuaram as mesmas, tentativa de aproximação e colocação de um diálogo em curso, nenhum sucesso foi obtido, uma vez que, não houve 
receptividade à presença da pesquisadora. A educadora não manteve a conversa e, sim, recusava, ignorava e se distanciava da pesquisadora e dos bebês.

O momento do retorno é por ocasião da "disputa de fraldas" entre os bebês. Quando Raimunda, pegou, retirou e isolou Mariana em uma cadeirinha do outro lado da sala e deu "broncas" na garotinha. E qual ação de Mariana? Chorou e chorou, sozinha do outro lado da sala.

Em continuação, já entra em jogo o susto da pesquisadora com todas essas ações de Raimunda. Se a pesquisadora se assustou, imaginem como estariam todos aqueles bebês?

Nesse intervalo, Amanda avistou a pesquisadora sentada ao chão, como da outra vez! Ela engatinhou, subiu ao colo da pesquisadora. Esta apresentou alguns brinquedos, tentou algumas brincadeiras para que ela se interessasse, mas não aconteceu.

Amanda sensível como era, parecia ter sofrido com os efeitos da ação da educadora e buscou refúgio no colo da pesquisadora. Acontece que a pesquisadora estava tão assustada que não sentia segurança em poder sustentar Amanda naquela situação. Além disso, temia que ao tirar a criança do colo, ela começasse a chorar e fosse retirada e isolada por Raimunda.

Amanda colocou os dois dedinhos na boca e adentrou em seu estado de desligamento. Para auxiliar Amanda naquele momento, a pesquisadora brincou com ela, percorrendo o corpinho dela com seus dedos, indo dos pés à barriga até chegar as mãozinhas dela. Repetiu a brincadeira algumas vezes, até que ela pareceu relaxar, tirou os dedinhos da boca e voltou a trocar e a se comunicar com a pesquisadora.

Quando a pesquisadora tentou colocar Amanda no colchonete junto com as demais crianças, ela começou a chorar. Consentiu que ela ficasse um pouquinho mais no colo, mas quando chegou a hora da pesquisadora de ir embora, o choro de Amanda começou. A pesquisadora tentou buscar alternativas para que ela se acalmasse, iniciando uma brincadeira com alguns brinquedos, mas não deu tempo... Raimunda não permitiu, retirou Amanda e a colocou no berço, gritando e dando broncas nela...

A cena continuou com o choro e os olhares de apelo de Amanda para a pesquisadora que não conseguiu agir e sair da posição inerte em amparo dela. Como ela não recebeu o que precisava, continuou olhando para pesquisadora e retomou seu balanceio até cair exausta no sono. Esse era o sinal de desistência de Amanda diante do efeito de paralisação da pesquisadora pela ação de Raimunda. 
Então, vejamos quais eram as ações da educadora com as crianças e com a pesquisadora? Pegar, retirar, isolar e gritar com as crianças! Recusar, ignorar, distanciar e não permitir ações da pesquisadora em direção à ela ou aos bebês!

Observamos que as ações de Raimunda geravam efeitos de detenção, impedimento e paralisação das ações de outros.

\section{Cena 5: Rosa, Heloísa e Vânia}

Essa cena aconteceu no período de alimentação das crianças, às 14 horas era tempo das mamadeiras na creche. O número de crianças no berçário I, era naquele momento, de 32 bebês.

As educadoras costumavam colocar os bebês sentados em cadeirinhas tipo bebê conforto e, diga-se que, de conforto não ofereciam muito.

Heloísa ingressou na creche em fevereiro aos 4 meses de idade e permanecia por um período de 6 horas diárias. No momento desse fragmento, ela contava com 7 meses. Heloísa era um bebê que observava muito as pessoas a sua volta e parecia desconfiada. Séria, sorria seletivamente e também não estabelecia um contato à primeira vista, era preciso um tempo de convivência para que ela se deixasse pegar ao colo, brincar e sorrir.

Vânia demonstrava uma relação de maior proximidade $e$ cuidados com Heloísa. Quando a criança demonstrava querer algo, sempre acompanhava a educadora com olhares, a chamava, levantava os bracinhos na direção dela ou chorava olhando para ela. Na hora das mamadeiras, Vânia colocava a bebê próxima a ela e costumava alimentar e conversar com ela. Havia mesmo uma conversa entre elas, pois Heloísa olhava fixamente para Vânia e respondia vocalizando e sorrindo. Vânia e Heloísa pareciam gostar muito uma da outra. 
Nesse dia, Rosa estava sentada em uma pequena cadeira em frente alguns bebês que, sentados em suas cadeirinhas aguardavam suas mamadeiras. Ela estava alimentando Heloísa que estava na cadeirinha ao chão. Enquanto Rosa a alimentava, Heloísa chorava muito e olhava na direção de Vânia, que estava com outro bebê ao colo, alimentando-o.

Rosa segurando apenas a mamadeira, exercia esta ação de forma forçadamente insistente contra a boca de Heloísa, esta parecia não querer a mamadeira e era alimentada entre lágrimas. Em dado momento, Heloísa engasgou. Ao que a pesquisadora assustou-se! Nesse instante, Rosa interrompe a oferta da mamadeira para Heloísa que continuava chorando em seu bebê conforto.

Diante do choro forte de Heloísa, a educadora decidiu colocála para dormir, afirmando que Heloísa estava com sono e iria dormir. Rosa levanta-se rapidamente da cadeira e se volta para Heloísa. A educadora levanta-a bruscamente da cadeirinha em direção ao colo, com impulso do próprio corpo, de forma que todo o corpo de Heloísa foi arremessado em direção à educadora, gerando uma espécie de tranco.

Enquanto tomava esta ação, Rosa se dirigiu para Vânia e afirmou que daquele modo estava resolvendo a questão com Heloísa. Vânia não disse uma palavra, olhou a ação de Rosa e continuou alimentando a outra criança.

Durante a colocação no berço, o gesto de Rosa também foi realizado de forma brusca, despejando Heloísa no berço e arremessando um cobertor por cima da criança, o que sófez aumentar o choro... Isso continuou por cerca de 30 a 40 minutos até que Heloísa adormeceu por exaustão.

Quem era Heloísa? 
Um bebê de 7 meses bastante observadora e atenta, parecia desconfiada, sorria seletivamente, pois sorria mais para Vânia e não estabelecia contato de forma imediata com pessoas que ela não convivia com frequência.

Em suas ações, era uma criança que olhava os adultos no ambiente, os acompanhava com o olhar, especialmente Vânia, a educadora por quem Heloísa parecia ter preferência. Solicitava chamando, esticando os bracinhos na direção dela ou chorava quando precisava de algo.

Vânia é educadora conhecida nossa (já a citamos em cena anterior), costumava acompanhar, conhecer sobre as crianças e oferecer cuidados. Nesse caso, ela olhava, conversava, colocava perto, pegava e atendia aos apelos de Heloísa, havia comunicação e troca entre elas.

Logo de início, vemos que Heloísa apresenta capacidade de discriminar entre os adultos que lhe são conhecidos e lhe oferecem cuidados. As demonstrações de relacionamento com Vânia aparecem nas ações da criança, assim como, sua relação amorosa e de preferência por ela. Interessante como Heloísa revela outra forma de contato (desconfia, não sorri, não brinca) com as pessoas que ela não conhece ou não possui contato estabelecido.

Na cena, Rosa é quem decide alimentar Heloísa. E o que se vê?

Rosa sentada de frente para os bebês, que sentados em cadeirinhas aguardavam suas mamadeiras. Não há contato corporal com nenhum dos bebês. Ela alimentava Heloísa na cadeirinha enquanto a criança chorava.

O que estava acontecendo?

Heloísa chorava e olhava Vânia que alimentava um bebê ao colo...

Se, por um lado, em suas ações Rosa forçava e insistia com a mamadeira, por outro, Heloísa, chorava, recusava e engasgava... Todas ações da criança na cena!

E Rosa?

Não oferece contato corporal para a criança, insiste com o alimento, depois pega ao colo de forma brusca para retirar a criança do grupo a ser alimentado. Informa Vânia que está resolvendo a questão e despeja Heloísa no berço para dormir, arremessando o cobertor sobre ela e deixando-a sozinha e chorando.

E Vânia? Permanece em silêncio e alimentando outro bebê. 
E a pesquisadora? Se assusta, observa, também aparece imóvel nessa cena.

E Heloísa? Ela permanece em sua ação, chorando e olhando para Vânia do berço. Continuou chorando por um longo tempo até ser vencida pelo cansaço. Ela desistiu...

Nessa cena não há atendimento da necessidade de Heloísa por nenhum dos adultos presentes. Como isso acontece?

Rosa parecia não estar disponível para o contato com Heloísa, ofereceu a mamadeira à distância, aparentou perceber que Heloísa (re)clamou por Vânia, mas não há movimento na direção de acolher o pedido da criança. Ela resolveu o "problema" retirando a criança e impondo aquilo que ela chamou de sono, levando-a para o isolamento no berço.

Vânia permaneceu em silêncio e continuou o que está fazendo. E a pesquisadora observou e não se movimentou.

$\mathrm{O}$ adulto que se mostra mais em cena é também aquele que aparece pela força, aquele que insiste, força, retira bruscamente, despeja ao berço, arremessa a coberta e, deixa sozinho o bebê. Outros dois adultos aparecem pelo silêncio, no entanto, um se mostra pelo aparente consentimento diante da situação e o outro (pesquisadora) aparece pela inação.

Contudo, a criança em seu movimento continuou chorando ao longo do tempo e, em consequência do não-atendimento, chegou a desistência, mostrou a ausência do adulto e dos cuidados.

\section{Cena 6: Raimunda e Lucas}

Lucas entrou na creche em abril, com 3 meses de idade, ficava 6 horas por dia na creche, fazia parte do grupo de bebês do berçário I e foi transferido para o berçário II em novembro, quando contava com 10 meses.

No momento em que acompanhava essa cena, Lucas estava com um ano e um mês de idade e fazia parte do grupo do pré-mini que tinha, aproximadamente, 20 crianças. Esse grupo continuou sobre os 
cuidados da mesma educadora do berçário II e mais uma educadora nova para o grupo de crianças.

Lucas era um bebê que chorava pouco, enquanto esteve no berçário I era acompanhado bem de perto por uma educadora que gostava muito dele. Era um bebê quieto e solicitava pouca atenção de adultos. Com a aquisição da capacidade de locomoção, as solicitações eram ainda mais esparsas, pois Lucas buscava objetos pela sala e permanecia bastante entretido com eles.

Ao passar para o berçário II seu comportamento quieto e menos dependente das educadoras se manteve, embora, fosse mais notado quando disputava brinquedos e objetos com outras crianças. Isso o fazia ser mais procurado pelas educadoras, pois nas disputas, às vezes, Lucas empurrava ou batia em outros bebês.

Um final de tarde, na sala do pré-mini, acompanhava o período de jantar dos bebês. E Lucas não se alimentava, chorava, espalhava a comida no prato com as mãos, às vezes se recusava receber a colher de comida dada pelas educadoras, na ocasião eram duas que se revezavam alimentando todos os bebês presentes.

Raimunda já irritada com a criança, no momento de oferecer o alimento ao bebê, fez um gesto brusco e forçou a colher contra a boca dele. Lucas para se livrar do gesto da educadora, jogou o corpo para traz com ajuda dos pezinhos que estavam apoiados na ponta da mesa e caiu da cadeirinha, bateu com a cabeça no chão.

Em cena se nota o movimento dos personagens envolvidos, o bebê, as duas educadoras e a pesquisadora. A segunda educadora e eu nos assustamos e partiramos em direção ao bebê. A educadora o pegou ao colo, olhou para ver se estava tudo bem com ele e depois o recolocou na cadeirinha. Raimunda ficou olhando a situação.

Raimunda que o alimentava, verbalizou que ele estava com sono porque não dormira a tarde. Ela se mostrava preocupada com a segunda educadora e comigo. Raimunda deixou de alimentar os bebês 
e começou a organizar as sobremesas e a sala, deixando o término do jantar para outra educadora.

Permaneci auxiliando a segunda educadora a terminar de alimentar os bebês. Quando terminamos, era hora de ir embora. Ao me despedir das educadoras, Raimunda se desculpou sem mencionar a situação. Optei em não falar com ela sobre ocorrido naquele momento.

Na semana seguinte, na hora da troca, observei a relação entre Raimunda e Lucas. A educadora conversava com ele, Lucas olhava para ela. Depois, aconteceu uma brincadeira entre eles em que Lucas esticava as pernas e tocava com o pezinho o rosto de Raimunda e, ela tirava o pezinho com um tapinha. Eles se olhavam durante toda a brincadeira e pareciam se divertir um com o outro.

Perguntei à educadora como Lucas havia ficado na semana anterior. Inicialmente, Raimunda procurou tratar a questão como um problema do próprio bebê que estava com sono, se referindo à ele como "sem vergonha", de modo carinhoso. Minha impressão era que Raimunda estava demonstrando estar ligada em Lucas. Pegou o bebê no colo, apertou-o em um abraço, ao que ele riu e o colocou no chão.

A partir daí, seguiu-se uma longa conversa entre nós duas. Raimunda contou de sua insatisfação com a mudança de sala, pois estava trabalhando com uma faixa etária que ela não gostava, preferia a faixa etária anterior, o grupo do berçário II. Contou o quanto não se sentia ouvida pela coordenação da creche, que não considerava sua preferência pelo outro grupo.

Mencionou as dificuldades de relacionamento entre ela $e$ a coordenadora, entre as educadoras e a equipe técnica da creche etc. A conversa se desenrolou até chegar ao momento em que Raimunda se remeteu aos momentos iniciais da pesquisa na creche. Começou a falar sobre a entrada das pesquisadoras na creche e como o modo de tratamento das educadoras com as pesquisadoras tinha sido hostil. 
Raimunda mostrou-se disponível para falar sobre a nossa relação. Acolhi a conversa e reconheci a hostilidade das educadoras e também apontei a mesma posição hostil de Raimunda.

A educadora relatou que não queria ser hostil como as outras e se desculpou. Nesse ponto, esclareci que apesar de receber a hostilidade direcionada a mim, compreendia que não era um problema, pois era capaz de lidar com um relacionamento nessas bases.

E continuei discorrendo que a hostilidade era percebida não somente direcionada a mim, mas que essa hostilidade deslizava e transbordava para a relação com o grupo de bebês, isso sim, motivo de preocupação, uma vez que, os bebês não tinham como lidar com situações de hostilidade e violência. Frente ao estabelecimento dessa relação, tecida por essas palavras a educadora pareceu se deixar tocar. Lágrimas brotaram de seus olhos...

Nas três semanas seguintes a essa conversa, o que se notou foram aspectos diferentes na relação entre Raimunda e Lucas, assim como com os outros bebês do grupo. Foi possível ver, pela primeira vez, a educadora conversando mais com as crianças. Vi Raimunda pedindo que Lucas nomeasse figuras que estavam coladas na parede, também vi, Lucas enroscado no corpo de Raimunda, mastigando o cordão de sua blusa e com as duas mãos apoiadas sobre os peitos dela. Observei Raimunda brincando e cantando com as crianças.

Pela primeira vez, a Raimunda parecia permeada por leveza e satisfação que aparentava desdobrar-se em uma espécie de divertimento com os bebês!

Destacamos de partida que Lucas estava experimentando a terceira transição de grupo na creche. Ele era um menino quieto, raramente chorava e não solicitava os adultos. Ele demonstrava maior autonomia, explorava a sala e buscava objetos mais do que os adultos presentes. Com a transição para o BII, ele era notado mais pelas "encrencas" que arrumava com 
outras crianças pelos brinquedos, ocasião que as educadoras o chamavam pelo nome ou se dirigiam até ele para apartar as disputas.

Vê-se que Lucas se mantém silencioso e dirige poucas solicitações para os adultos. Ele é visto e mais procurado pelos adultos por suas travessuras.

Nessa cena, vemos Lucas no horário de jantar. Ele não se alimentava, chorava, espalhava a comida com as mãos pelo prato e recusava as colheradas de comida dadas pelas educadoras. Essas eram as ações dele nesse momento.

As duas educadoras se revezavam para alimentar os bebês, elas ajudavam oferecendo colheres com comida na boca dos bebês, mas eles também comiam sozinhos.

As impressões eram de que Lucas estava agitado, inquieto e não parecia querer jantar. Raimunda mostrava irritação com a criança. E, no momento de ajudá-lo, de forma brusca, forçou a colher contra a boca de Lucas.

A ação de Raimunda é forçar a colher de comida na boca de Lucas, é insistir para que ele se alimente. E, complementar a ação dela, a ação de Lucas é jogar o corpo para trás com ajuda e impulso dos pezinhos apoiados na mesa. Ele faz ação para livrar-se do gesto de Raimunda, ele recusa...e cai!

A segunda educadora e a pesquisadora se assustaram com a queda de Lucas e se dirigiram à ele para recolhê-lo do chão. A educadora o segurou no colo, observou se ele estava bem e o recolocou na cadeirinha. Raimunda permaneceu olhando...

Educadora e pesquisadora se assustam e partem na direção de Lucas, para pegar e verificar se ele estava bem, se não havia se machucado na queda. Aqui, o susto não impediu a ação de ambas as personagens na cena. O interessante é que Raimunda aparece imóvel, pois ela permaneceu olhando... Ela mantém essa ação!

Raimunda ficou imóvel e não parecia preocupada com a queda de Lucas. A ação seguinte dela foi dizer que ele estava com sono porque não havia dormido à tarde. E deixou a atividade de alimentar os bebês para arrumar as sobremesas e a sala.

Vemos que as ações seguintes de Raimunda são deixar a atividade, se retirar para organizar as sobremesas, que podemos inferir, fariam o fechamento do jantar dos bebês. Ela procurou deixar, sair da situação. 
Contudo, antes de se retirar, Raimunda revelou seu entendimento da agitação de Lucas durante o jantar, ela disse que ele estava com sono. Ela demonstrou saber o que acontecia com ele e, no mesmo gesto, revelou o que não sabia... Como cuidar de Lucas com sono?

Em sua ação marcada pela força e irritação, vimos também a outra face, a imobilidade de Raimunda para cuidar.

Nesse dia, Raimunda que manteve-se à distância após ter se retirado da cena, na hora da despedida se desculpou com a pesquisadora. Esta, como estratégia, optou por abordar a educadora em outro momento, após transcorrido o período de irritação em que Raimunda se encontrava. A ação da pesquisadora foi adiar e aguardar...

Na semana seguinte, a pesquisadora viu outra cena entre Raimunda e Lucas. Ao chegar para visita encontrou a educadora trocando o bebê e em uma relação marcadamente diferente, pois ela conversava com ele, ambos brincavam e se olhavam durante essa relação de cuidado. Pareciam demonstrar interesse um pelo outro e usufruir da presença um do outro, acontecia uma troca entre eles.

A pesquisadora abordou a educadora para retomar a ocorrência da semana anterior. De primeiro, Raimunda atribuiu à Lucas e seu sono os possíveis motivos da situação toda, o chamou de "sem vergonha", talvez na tentativa de ratificar que a queda foi provocada por ele e que ela não tinha implicação com a situação. É aí, que ela se entregou, pois, ao chamar Lucas de "sem vergonha", o fez de forma amorosa, ao contrário do que se poderia pensar, Raimunda deixou escapar sua ligação com Lucas. E as ações seguintes dela nos indicam essa direção, pois ela pegou ao colo, apertou e abraçou Lucas. E Lucas riu, indicando satisfação com o gesto dela.

Isso para mostrar que Raimunda fez tentativas de se retirar da cena, mas ao fazer atribuição à Lucas e, especialmente ao chamá-lo de "sem vergonha" se implicou na situação, revelou seu envolvimento com Lucas e com a situação toda. Vejamos como continuou...

A primeira intervenção da pesquisadora foi a instalação de uma conversa sobre Lucas e a situação da queda dele na semana anterior. O que seguiu-se a essa conversa foi a abertura para uma oura conversa que muda de rumo. A conversa desliza da relação de Raimunda com o bebê e aterrissa nas paragens da relação de Raimunda com a instituição.

E, nessa conversa, Raimunda falou de sua insatisfação com a mudança no trabalho, pois não gostava de trabalhar com a faixa etária atual, preferia continuar com a turma do BII. Mencionou não se sentir ouvida pela coordenação da creche, pois não considerou sua preferência pelo trabalho com o outro grupo. 
O que está acontecendo?

Raimunda está falando de si! E falou de sua insatisfação, falou dos aspectos que não gosta, falou do sentimento de não ser ouvida e que na creche, as pessoas não levam em consideração o que é dito por ela.

Ela seguiu dizendo. Havia dificuldades de relacionamento entre ela e a coordenadora ${ }^{22}$, entre as educadoras e a equipe técnica da creche, enfim, ela foi dizendo das dificuldades que encontrava no contexto de relações do trabalho naquela instituição, estava falando, também, da instituição e suas relações.

Raimunda foi adentrando as relações que ela vivencia e as dificuldades que apareciam nessas relações e, novamente, fez outro deslizamento, desta vez para a relação com as pesquisadoras na creche.

A educadora chegou ao ponto em que enunciou a hostilidade que o grupo de educadoras dirigia ao grupo de pesquisadoras. De fato! É fato, também, que Raimunda expunha esses atos e se retirava deles, falando sempre de outros, suas falas eram sempre em terceira pessoa do singular ou do plural: ela ou elas. Pois era a coordenadora, a equipe, as educadoras, as pesquisadoras...

Ao mesmo tempo e ato, Raimunda falou sobre os atos e falou sobre si, parecendo disponível para falar sobre a hostilidade e sobre a relação com a pesquisadora. É nesse ponto que a pesquisadora acolheu as falas e o gesto de Raimunda. Reconheceu a hostilidade das educadoras para as pesquisadoras e, apontou a mesma hostilidade presente em Raimunda nas relações com as pesquisadoras, trazendo Raimunda para dentro da cena.

A ação de Raimunda foi se desculpar, nova tentativa de recuar, de se retirar, talvez. (Ela estaria repetindo a mesma ação do jantar, após ter se retirado da cena? Desculpar-se?). A pesquisadora insistiu na conversa, acrescentando que recebia a hostilidade de Raimunda e pode se relacionar com ela nesses termos durante a pesquisa. E, percebia que essa mesma hostilidade era dirigida para o grupo de bebês, esclarecendo que estes sim, não podiam lidar com relações carregadas de hostilidades, pois eram muito pequenos e sem recursos para tal.

\footnotetext{
${ }^{22}$ Raimunda era a educadora que a coordenadora da creche mencionou dificuldades de relacionamento devido a hostilidade e solicitou a pesquisadora que conversasse com ela sobre o Termo de consentimento da pesquisa. Este dado vai na mesma direção dos apontamentos de Raimunda nessa conversa. (Para recuperar essa informação, ver item “As relações na creche A: educadoras, equipe da creche e pesquisadora” - capítulo o Contexto das creches).
} 
Nota-se que há, em Raimunda, um movimento para falar sobre a hostilidade, ao mesmo tempo que faz tentativa de retirar-se como protagonista, buscando a posição de coadjuvante em cena. No entanto, a pesquisadora, recoloca Raimunda em cena tanto em relação com a pesquisadora, quanto em relação com os bebês, na tentativa de mostrar para educadora de que estávamos todos envolvidos: educadoras, bebês e pesquisadoras.

Essa conversa que se seguiu: Educadora e Pesquisadora juntas, pareceu ter exercido efeito, pois Raimunda se emocionou, suas lágrimas vieram e o silêncio tomou conta do momento, parece que Raimunda se deixou tocar.

A ação da pesquisadora com Raimunda foi construída por movimentos de avanços e recuos, entre observar e aguardar, até que a oportunidade de ser ouvida pela educadora se apresentasse.

E o interessante é que a oportunidade se abriu também na oferta de um espaço para Raimunda, entre educadora e pesquisadora criou-se um campo possível para Raimunda falar de suas relações com Lucas, das relações com as pessoas da instituição e da própria instituição, da relação com o grupo de pesquisadoras e, finalmente com esta pesquisadora. E falar sobre o quê? Sobre a hostilidade que caracterizava as ações de Raimunda nas diversas relações que ela travava em seu cotidiano de trabalho. Sim, travava, porque Raimunda tanto freava, impedia como também se ligava, se unia as pessoas.

Observamos que um espaço se instalou para Raimunda falar de si em sua singularidade nessas relações. E pudemos acompanhar os atos que se desdobraram a partir dessas intervenções com a educadora.

Raimunda também ganhou visibilidade....

Nas semanas seguintes, verificamos diferenças na relação de Raimunda e Lucas, entre Raimunda e os demais bebês. Raimunda conversava mais com os bebês, ela pedia que Lucas nomeasse as figuras expostas na sala, ela brincava e cantava com as crianças.

E Lucas? Ele se enroscava no corpo dela, mastigava o cordão da blusa da educadora, apoiava as mãozinhas nos peitos de Raimunda. Existia ali, proximidade entre eles, uma relação de cuidado e intimidade com Lucas. Ela apresentava objetos para ele, solicitava que Lucas nomeasse, incentivava a comunicação com ele, de fato, eles agora pareciam se comunicar. 
Raimunda, pela primeira vez, parecia livre da ira, da fúria que a acompanhava, a impressão era de que ela estava leve, satisfeita e podia aproveitar da relação com os bebês, trocar com eles, se divertir, pois ela demonstrava conseguir brincar e cantar com eles.

Parece que Lucas e as crianças ganharam espaço de visibilidade para Raimunda, elas passaram a ter existência na relação com ela, talvez, se possa dizer, que a própria Raimunda ganhou espaço de existência na creche, ao ser vista em suas ações e (re)ações...

\section{Cena 7: Rosa, Juliana e Laura}

Rosa sentou-se com as crianças no chão, nesse período de acompanhamento haviam 34 bebês no grupo do berçário I. A educadora permaneceu perto de Juliana (9 meses) e Laura (6 meses e meio), ambas permaneciam 8 horas na creche. Aproximei-me e sentei ao chão com elas. Iniciamos uma conversa sobre Juliana - “docinho” (apelido derivado do sobrenome da criança), como era chamada pela educadora.

Juliana era uma criança de fácil contato. Era sorridente, tentava conversas, procurava os adultos para interagir, solicitava colo, abraçava, gostava de brincar e trazer brinquedos, estava sempre em busca de uma parceria.

Laura era um bebê atento a sua volta, gostava de pessoas por perto, também buscava o contato e esticava os bracinhos para ser pega ao colo. Seu modo de alcançar que precisava era chorando, também era um bebê de fácil contato.

Rosa brincava de cantar parabéns para “docinho” que não apenas correspondia batendo palmas, bem como dava gargalhadas. Comentei com Rosa que percebia que “docinho” demonstrava gostar muito dela, ao que educadora respondeu que era porque ela também gostava muito de Juliana. Eu disse que notava que Juliana era o bebê 
preferido dela, então Rosa começou a contar que tinha alguns bebês preferidos, como João, por exemplo.

Diante disso, Rosa se entregou a uma brincadeira gostosa de ver. Deitou-se no chão e colocou "docinho" em sua barriga. Continuou cantando parabéns e, vez por outra, abraçava Juliana. Laura, que também gostava de Rosa, vendo o que acontecia se aproximou e foi incluída na brincadeira pela educadora.

Rosa aconchegou Laura, envolvendo-a com o braço $e$ aproximando-a em seu peito, cantava, olhava para Juliana, olhava para Laura, abraçava ambas as meninas, sorria com elas.

Um tempo depois, Rosa observando João que chorava, tentou dar-lhe a chupeta e ele não pegava. Rosa procurou uma mamadeira, aqueceu e deu para o bebê. $O$ interessante foi que ela se refugiou em um cantinho com o bebê. E, enquanto o alimentava parecia tentar ninálo com uma fraldinha no rosto.

Passado algum tempo, enquanto acompanhava as trocas de outras crianças, Rosa comentou que iria dar um banho em "docinho" e convidou-me para ver.

Durante o banho, Rosa conversava com a criança e parecia satisfeita em fazê-lo, sem a obrigação com que demonstrava fazer os cuidados de forma geral.

Nesse momento, Rosa contou-me que para algumas crianças ela gostava de fazer um agrado, assim como para “docinho”. Falou das lembranças que guardava de outras crianças de quem cuidou. E que houve um bebê que ela gostava de dar banho e que mesmo depois de crescida e, estando em outra turma, vez por outra, a menininha voltava para que Rosa desse um banho nela. E que a criança ainda hoje se lembrava deste cuidado, o que a deixava muito feliz. 
Lembramos que Rosa era uma das educadoras destacadas em nosso estudo como pertencendo ao grupo mais distante e pouco disponível para o contato com a pesquisadora. As aproximações e conversas se faziam necessárias não apenas para facilitar a abertura de espaços para falar sobre os bebês e seus cuidados, mas, também, para inserir a pesquisadora no contexto de relações das educadoras.

A pesquisadora se aproximou de Rosa, sentou com ela ao chão e iniciou uma conversa sobre Juliana. Já era de conhecimento da pesquisadora que Juliana era carinhosamente, chamada por Rosa de "docinho".

Juliana era um bebê fácil e era vista a maior parte do tempo sorrindo. Ela buscava os adultos para interagir, abraçava e esticava os bracinhos para solicitar colo, gostava de brincar, trazia brinquedos como convites para as brincadeiras, enfim, era uma criança que buscava o contato e parceria com as pessoas.

Vê-se que as ações de Juliana são abraçar, esticar os braços, brincar e trazer brinquedos; são ações que mostram como essa criança abordava o outro. Ela cercava, segurava e envolvia o outro, ela se esticava, se encompridava para alcançar alguém e ofertar objetos para compartilhar em brincadeiras. Juliana se lançava em direção do contato, da parceira.

Laura era um bebê sempre atento ao seu redor e parecia gostar de pessoas por perto. Ao se ver com adultos esticava os bracinhos para ser pega ao colo ou chorava para ser atendida ou vista pelos adultos, também era um bebê de fácil contato. Do mesmo modo, vemos que Laura se esticava para estar com o outro, ela chorava para ser ouvida, ser atendida por alguém.

As duas crianças estavam bem próximas de Rosa quando se inicia uma brincadeira de cantar parabéns entre Rosa e "docinho". Rosa cantava e "docinho" batia palmas, as duas sorriam!

Elas demonstravam interesse uma pela outra e pareciam gostar muito uma da outra, além de se divertirem juntas. E, é diante desse cenário que a pesquisadora comentou com Rosa que percebia que "docinho" gostava muito dela, o que a educadora não apenas confirmou e, acrescentou que era porque ela gostava muito de Juliana!

Nota-se que a ação da pesquisadora foi ressaltar um aspecto presente em Juliana na relação com a educadora, ou seja, o afeto por Rosa, ao que a educadora revelou sua preferência pela criança. E, a partir disso, a pesquisadora afirmou que notava que Juliana era o bebê preferido de Rosa. 
O que se seguiu foi Rosa dizer que tinha outros bebês preferidos e citou João como exemplo. E o que aconteceu?

Rosa se entregou a uma brincadeira muito gostosa com Juliana, pois deitou-se no chão, colocou “docinho" em sua barriga e cantou parabéns, às vezes, abraçava Juliana. Aliás, a brincadeira de Rosa com Juliana, pareceu despertar o interesse de Laura que se aproximou e foi incluída na brincadeira.

Quais são as ações de Rosa?

Deitar-se ao chão, colocar "docinho" em sua barriga, cantar para ela, abraçar a criança e incluir e aconchegar Laura junto ao peito durante a brincadeira. Essas ações indicavam a entrega, a disponibilidade, o envolvimento e a liberdade de Rosa para estar com as crianças e oferecer outros tipos de cuidados.

Observa-se ainda que o tipo de relação que se estabelece inclui a educadora e as crianças de corpo inteiro, pois são brincadeiras que envolvem os corpos da educadora e das meninas, pois há Juliana na barriga da educadora, palmas, risos, o canto da educadora, os abraços dela em “docinho" e a inclusão de Laura no jogo, que também bate palmas e ganha olhares e abraços da educadora.

O movimento continua com o amparo de Rosa a João que chorava e não pegava a chupeta. Ela procurou uma mamadeira, aqueceu e alimentou João, se refugiando em um cantinho com ele. Aconchegou ele em seus braços e parecia niná-lo com uma fraldinha no rosto.

Nessas ações, a educadora mostrou que conhecia os bebês com quem ela admitiu um afeto especial, uma preferência. Com João ficou claro como ela soube o que se passava com ele, parece que ela identificou que o bebê tinha fome e se dispôs a atender as necessidades dele, encontrando uma mamadeira e ninando João, enquanto o alimentava pelos cantinhos, preservando um momento de pequena intimidade entre eles.

E o desfecho da cena chega com Rosa comentando e convidando a pesquisadora para ver o banho de "docinho". Aqui, a ação da educadora é comentar sobre o banho e convidar a pesquisadora para ver.

O que aconteceu?

A pesquisadora acompanhou o banho de "docinho" e viu como Rosa conversava com a criança durante o banho, viu também como Rosa parecia satisfeita em dar aquele banho. Não 
se tratava de uma atividade exercida de forma mecânica e automática, como tantas outras da rotina, havia prazer e satisfação envolvidos naquele ato.

A cena continuou com Rosa contando à pesquisadora que para algumas crianças ela gostava de fazer um agrado, assim como para "docinho". Talvez, ela estivesse dizendo que para as crianças que ela gostava, fazer "agrados" ou proporcionar cuidados era possível e satisfatório.

E, Rosa passou a contar sobre as lembranças que guardava de outras crianças de quem ela cuidou. Falou particularmente de um bebê que ela gostava de dar banho. E, mesmo crescendo e não estando mais em sua turma, ela continuou dando banhos. E, uma vez ou outra, a menininha voltava para que Rosa desse um banho nela. E que a criança, nos dias de hoje, ainda se lembrava desse cuidado, o que a deixava feliz...

Quantos desdobramentos aconteceram, vejamos, o primeiro deles aparece no comentário sobre o banho de "docinho" e o convite para a pesquisadora acompanhar essa ação.

Rosa é quem se aproxima da pesquisadora, inicia uma conversa e faz um convite. Que convite? Para acompanhá-la em um banho ao bebê. Rosa agora convida a pesquisadora para vêla fazendo algo. E vemos Rosa exercendo um cuidado espontâneo e demonstrando satisfação em fazê-lo.

Outro deslizamento aparece nessa ação, pois Rosa revelou que gostava de fazer agrados a algumas crianças. Aqui, parece que a educadora retoma a conversa inicial com a pesquisadora, ao falar de suas preferências e, amplia a conversa na medida que traz lembranças de outras crianças e de outros agrados. Lembranças de outros tempos...

Rosa desliza novamente, desta vez, para suas memórias e brinda a conversa com o que guardava em seu "coração", a lembrança de uma menininha que ela viu crescer, enquanto dava banhos e agrados. E no mesmo ato, desnudou como se sentia feliz ao ser lembrada pela pequena criança.

Rosa é a protagonista dessa cena, é ela quem conta sobre as crianças que ela agradava, ela é quem relembra outros tempos e outras crianças, ela é quem desnuda sua lembrança mais remota e se diz feliz ao ser lembrada.

E a pesquisadora? Viu e ouviu, aceitando o convite! Viu Rosa se abrir para uma comunicação com a pesquisadora, desabrochar em cuidados a "docinho" e narrar, aos ouvidos não menos atentos da pesquisadora, histórias vividas e (re)lembradas... 
Ao ser vista em suas ações e ouvidas em suas recordações, Rosa também ganhou visibilidade e mostrou, como em sua existência, pode cuidar e já cuidou, ao trazer, de outros tempos, memórias de cuidados que a fizeram feliz.

O brilho dessa história regada a água morna é que a narrativa nasce ao banhar uma menininha em cuidados que se (re)fazem a cada ato-palavra (re)vividos!

\section{Cena 8: Vânia, Heloísa ${ }^{23}$ e Bianca}

Ao meio da tarde, alguns bebês dormiam e estavam apenas as educadoras Vânia e Camila no berçário que comportava o total de 36 crianças.

Heloísa (8 meses) estava no colchonete no chão e começou a reclamar a atenção de Vânia, resmungando e gritando.

A educadora estava na bancada de trocas e ao perceber o chamado de Heloísa passou a conversar com ela à distância. A criança parava de gritar para ouvir o que Vânia dizia e recomeçava sua solicitação assim que a educadora silenciava.

Vânia, então, dirigiu-se a ela, pegou Heloísa ao colo e a convidou para ajudá-la, dizendo: "Heloísa, você quer me ajudar? Preciso escrever algumas coisas". Colocou Heloísa sentada na bancada à sua frente e continuou conversando com a criança.

Vânia explicava que estava pegando o papel para algumas anotações e que ela poderia ficar ali, deixou que Heloísa pegasse um objeto na bancada de troca e ficaram conversando.

Heloísa fazia algumas vocalizações na interlocução com a educadora. Vânia respondia, vez por outra, elas trocavam olhares. As

\footnotetext{
${ }^{23}$ Essa dupla já foi mencionada em cena anterior.
} 
duas ficaram juntas durante um bom período de tempo. Isto pareceu acalmar e atender Heloísa.

Ao terminar as anotações, Vânia retornou com a pequena ao centro da sala e colocou Heloísa no chão com Bianca (6 meses). Como esta última ainda não sentava sozinha, a educadora sentou-se atrás de Bianca, apoiando-a em seu colo e colocou Heloísa à frente dela e de Bianca. A educadora disponibilizou alguns brinquedos, Heloísa preferiu o crachá de Vânia com algumas chaves penduradas, a educadora tirou o crachá do pescoço e deu para Heloísa e permaneceu brincando com as duas meninas.

Durante a brincadeira, Vânia incentivou o contato entre as meninas. Isto favoreceu que Heloísa ficasse tranquila e aproveitasse da presença de outra criança.

Heloísa e Bianca permaneceram se olhando e interagindo e, quando a educadora precisou se retirar para atender outro bebê, Heloísa deixou Vânia ir e se manteve tranquila com o afastamento dela e a presença de Bianca.

Relembramos que Heloísa foi mencionada na cena 5, vamos apenas recordar um pouquinho sobre ela... Era uma criança bastante observadora e atenta, parecia um pouco desconfiada, sorria seletivamente, pois sorria mais para Vânia e não estabelecia contato de forma imediata com pessoas que ela não convivia com frequência. Ela acompanhava Vânia com o olhar e a solicitava, chamando, esticando os bracinhos na direção dela ou chorando.

Nesse momento, Heloísa estava com 8 meses de idade e para chamar a atenção de Vânia, a criança estava resmungando e gritando. Observamos que as ações e a comunicação de Heloísa estavam se ampliando, pois ela aprendeu a gritar para chamar!

Vânia não estava perto da criança, mas percebeu que era um chamado de Heloísa para ela e passou a conversar com a criança, respondendo ao chamado. Heloísa que estava gritando, diante da resposta da educadora parava de gritar para ouvir o que Vânia dizia e, recomeçava logo que o silêncio de Vânia aparecia. Acontecia uma comunicação entre elas, no intervalo 
entre o chamado da criança, a resposta da educadora e uma pausa de comunicação que permitia continuidade da conversa entre elas.

Então, vemos que Vânia percebe e responde ao chamado, conversando com Heloísa. A criança grita e cessa de gritar para ouvir o que diz a educadora, recomeça quando o silêncio se instala entre elas.

O que acontece?

Vânia foi ao encontro de Heloísa, ela pega a criança e leva com ela para o balcão de trocas. A educadora continua a conversa, convidando Heloísa para ajudá-la em suas tarefas e permite que Heloísa fique sentada à sua frente. A conversa segue com a educadora explicando o que precisava fazer e consentindo que Heloísa brinque com um objeto do trocador, nesse acontecer, uma comunicação vai existindo entre elas.

A criança realiza algumas vocalizações para Vânia, a educadora responde e as duas se olham, vez por outra, enquanto conversam. Permaneceram juntas por um período de tempo nessa comunicação, isso pareceu acalmar e atender Heloísa.

Vânia se mostrou disponível a estar com Heloísa, a permitir que elas estabelecessem um contato mais próximo e uma comunicação diante dos chamados da criança, o que se mostrou como um cuidado, pois Heloísa parecia (re)clamar a presença de alguém por perto.

O desfecho da cena se dá com Vânia levando Heloísa para o centro da sala e a aproximando de Bianca, uma menina menor que ela, mas uma criança para dar continuidade a um contato com Heloísa.

E o que Vânia faz?

Ela auxilia Bianca a sentar-se, oferecendo apoio à criança a partir de seu corpo. Posiciona Heloísa sentada à sua frente e, também, a frente de Bianca, oferta brinquedos as duas e Heloísa escolhe o crachá da educadora com as chaves. Vânia permite que Heloísa brinque com o crachá e continua brincando com as duas meninas.

Nessa passagem, notamos Vânia aproximando as duas crianças, facilitando o contato entre elas, de forma que uma pudesse aproveitar da presença da outra. A educadora faz isso, criando um espaço de convivência entre as duas meninas, levando brinquedos e brincando junto com elas. Também oferece à Heloísa um objeto pessoal, atendendo novamente uma solicitação da criança, parecendo compreender a importância do contato que se estabelece entre ela e Heloísa. Ela permite que Heloísa fique com algo seu. 
Além disso, ao aproximar Heloísa e Bianca e facilitar a convivência das duas, Vânia criou a possibilidade de afastar-se de Heloísa, sem que o distanciamento para atender outro bebê, perturbasse a tranquilidade e aparente segurança que Heloísa parecia sentir. 


\section{DISCUSSÃO}

\subsection{Entre Ações e "Conversações": delineando as relações de cuidados com os bebês nas creches}

Nossa discussão das análises das cenas dos cuidados com os bebês nas creches, apresenta o que observamos nas relações entre as profissionais e os bebês e como se desenham as relações de cuidados nas creches.

Para mostrar esse desenho das relações de cuidados apresentaremos nossa discussão, partindo de dados que guardam semelhanças e também daqueles que despontam pelas diferenças no decorrer das análises.

Ressaltaremos, primeiramente, o que depreendemos na análise dos personagens envolvidos nesses cenários, destacando o que aparece sobre os bebês, as profissionais e a pesquisadora no entrecruzamento da pesquisa.

Apresentaremos aspectos que se relacionam com as creches como instituições e outros que chamaremos de aberturas possíveis, espaço que discutiremos as relações de cuidados, demonstrando ao mesmo tempo, como foram feitas as intervenções e quais efeitos observamos, de forma a verificar a contribuição das relações de cuidados em creches para o desenvolvimento psíquicos dos bebês. 


\subsubsection{Os bebês}

\section{Comunicação e o Corpo}

Partimos do princípio que bebês choram. Chorar para o bebê, no início, se constitui como uma forma de comunicação privilegiada e com o avanço do desenvolvimento as formas de comunicação se ampliam até alcançarem a linguagem. Como trabalhamos com bebês muito pequenos e ainda sem a conquista da possibilidade de uso da palavra, o choro e os gestos foram tratados como modos de comunicação.

Começamos destacando que em algumas situações os bebês choravam sem receber assistência de adultos, como vimos com Amanda, Heloísa e Lucas. Nesses casos, o choro parecia não ser levado em conta pelas profissionais, não era algo que recebesse o olhar e/ou atendimento do adulto.

Verificamos que havia diferentes tipos de choros. Havia o bebê de choro baixinho, expresso por sons fracos, um chiado, que quase não se ouvia, mas havia o bebê de choro alto, forte e de longo alcance, havia quem, além chorar, podia resmungar e gritar. E também os bebês que choravam raramente ou não choravam.

Observamos que corporalmente os bebês apresentaram diferenças no desenvolvimento no que tange a articulação e coordenação do corpo, o tônus muscular, domínio do corpo e ao estabelecimento da relação com o próprio corpo.

Encontramos bebês aos 5 meses de idade (Amanda e Roberto) corporalmente frágeis, aparentemente demonstravam possuir pouca força, pouco domínio sobre o corpo, com menor articulação e coordenação das partes do corpo e dos movimentos. Em contrapartida, vimos outro, aos mesmos 5 meses que demonstrava maior força e vitalidade, o que aparecia na motilidade do bebê, especialmente quando ela chorava (Paula). 


\section{Pelos cantinhos: ocupação do espaço ou invisibilidade?}

Em nossas análises, apreendemos indicadores com relação a ocupação do espaço da creche e ao modo de estar dos bebês nesse ambiente.

Observamos que os bebês em que o domínio do corpo e a locomoção não eram presentes, permaneciam em berços ou colchonetes ao chão, em cadeirinhas de balanço e cadeirinhas tipo bebê conforto. Aqueles que já possuíam domínio do corpo a ponto de sentar ou se locomover permaneciam ao chão.

Com relação ao modo de estar na creche, verificamos que seis dos bebês se mantinham a maior parte do tempo quietos e silenciosos ou não chegavam a ser ouvidos, esses eram considerados como bebês "bonzinhos" pelas profissionais (Márcio, Lucas, Roberto, Amanda, Juliana e Laura). Esses bebês não pareciam ter suas presenças consideradas na creche, pois choravam baixo e pouco e outros deles não choravam e não reclamavam.

Verificamos também que os bebês ficavam sozinhos, alguns pelos cantinhos a olhar em volta (Márcio e Roberto), outro pelo cantinho porque seu choro não se mostrava potente o suficiente para chamar o adulto (Amanda), outros que demostravam alguma autonomia e buscavam menos os adultos (Márcio, Lucas).

Dos bebês que ficavam pelos cantinhos e possuíam alguma autonomia, eles mostravam mais adaptados à creche, seguiam as rotinas, não procuravam muito contato com adultos e nem os solicitavam, como era o caso de Márcio e Lucas, por exemplo.

Já, com Amanda, vimos que também ficava pelos cantinhos da creche, por sua vez, porque parecia não ser notada pelos adultos. E em seu desamparo apresentava comportamentos autoestimulatórios. Esses comportamentos pareciam fazer parte dos momentos em que Amanda não era atendida em suas necessidades, o que findava em desistência. Esses bebês apareciam na creche como parte do grupo dos bebês invisíveis, muito embora estivessem presentes, suas presenças não eram notadas pelos adultos.

Encontramos também os bebês que para além de permanecerem silenciosos, também se mostraram atentos, eles olhavam e observavam as demais pessoas no ambiente, eram aqueles que também se revelavam curiosos em saber o que se passava ao redor deles (Márcio, Heloísa, Laura, Juliana). Porém, vimos que entre os bebês quietinhos, havia aqueles que olhavam o 
ambiente ao seu redor e permaneciam desamparados (Roberto, Amanda). Eles eram deixados a seus próprios e frágeis recursos.

Em menor número, os bebês que conseguiam fazer suas presenças serem notadas na creche eram aqueles que conseguiam atrair para si os adultos, através, especialmente, de seus choros fortes ou gritos, como eram com Paula e Heloísa.

Heloísa conseguia atrair para si o acompanhamento de Vânia. Nos momentos em que Vânia não podia ou falhava em atendê-la e, outra profissional assumia os cuidados sem compreender e atender as solicitações de Heloísa, o que se apresentava era desistência, como resposta após longo período de choro.

Havia o bebê que conseguia se locomover e ir em busca das profissionais, nesse aspecto, Juliana não só "corria" atrás da educadora, como abraçava, sorria, levava brinquedos, ela demonstrava saber como trazer o adulto para si, ou melhor, se levar até o adulto, o que outros bebês ainda não conseguiam fazer.

De modo geral, os bebês permaneciam soltos no espaço da creche, pareciam entregues aos seus próprios recursos e sem a presença de adultos que os acompanhasse. Com isso, via-se que os bebês, especialmente os menores, choravam e acabavam adormecendo de exaustão, o que parecia indicar o sinal de desistência dessas crianças em serem vistas e atendidas em suas necessidades.

Fato que corrobora essa observação é a ausência de contato corporal com os bebês, como observamos, eles ficavam em berços, cadeirinhas de balanço, cadeirinha bebê conforto ou ao colchonete no chão. Eles não eram seguros ao colo, não eram aconchegados, ninados, nem mesmo em situação de alimentação, como pudemos mostrar.

Ainda, o que verificamos em relação aos bebês e o uso do espaço era a diferença existente no modo de abordagem, pois enquanto alguns não conseguiam nem mesmo mudar de posição, outros esticavam seus bracinhos em direção ao adulto ou o acompanhava com olhos atentos e, havia os que podiam se locomover e ir atrás dos adultos, conseguiam buscá-los com seus próprios corpos e recursos mais desenvolvidos.

Enquanto alguns choravam fraquinho e baixinho, outros podiam chorar forte e alto e havia aqueles que, além de chorar podiam gritar. E havia aqueles que, o modo de abordar o espaço era pelo silêncio, pela observação ou pelo desinteresse pelo contato com os adultos. 
Nesse sentido, o modo como os bebês ocupavam o espaço da creche, como era possível a eles estar e abordar tanto o espaço concreto, como os objetos ou as pessoas do ambiente era diferente entre eles, o que também marcava o acesso aos cuidados, uma vez que, fica evidente o desequilíbrio nos cuidados quando vemos os bebês em suas singularidades e diferentes etapas de desenvolvimento.

De modo geral, nota-se que esse grupo de bebês era pouco atendido em suas expressões de necessidades, permanecendo inicialmente em situação de falta de assistência de adultos, talvez, possamos dizer, que alguns permaneciam em desamparo.

Isso nos parece plausível, pois os bebês que ocupavam os cantinhos ou eram neles deixados, quando abordados pela pesquisadora nas visitas iniciais pareciam não responder aos chamados ou contatos, mas, aos poucos, foram puxados para fora desses cantinhos.

\section{Os primeiros contatos: (des)cobrindo os bebês}

Frente ao cenário que se apresentava, a pesquisadora inicialmente se aproximou dos bebês e procurou estabelecer um contato semanalmente com os bebês. Durante as visitas, procurava ver o que acontecia quando choravam, pegava ao colo, mudava de posição no berço ou colchonete, conversava, brincava e colocava brinquedos à disposição deles. E, principalmente, buscava conhecer cada bebê, observando, procurando compreender o jeito de cada um, quais gestos eles faziam na direção da pesquisadora e como respondiam aos gestos da pesquisadora no contato com eles. Observando o que acontecia nesses contatos.

Seguindo o que se notava e conhecia dos bebês iniciou-se uma maior aproximação com as profissionais no sentido de abordar o que conheciam sobre os bebês e, conversar sobre o que elas sabiam e o que a pesquisadora notava. Essas aproximações tinham como objetivo criar espaço para conversar sobre os bebês.

Com Márcio, a pesquisadora sempre o acompanhava em seu "brincar de esconder-se pelos cantinhos", além de chamar, mantinha contato visual com ele em todas as ocasiões em que ele se escondia em seus cantinhos. $\mathrm{O}$ interessante era que ele acompanhava a pesquisadora 
e o movimento do grupo e das profissionais, embora nos cantinhos, ele estava no grupo, mas sua presença silenciosa e distanciada parecia não favorecer sua existência naquele grupo.

A partir das conversas com a professora e de uma inicial amostra de como Márcio estava na creche, a professora passou a olhar e também ver Márcio pelos cantinhos. As conversas sobre a criança parecem ter feito a professora não apenas notar a presença do bebê, mas também a buscá-lo, uma vez que, com o "rapto" dele a professora demonstrou que estava mais ligada e disponível para um contato com ele. Ela parecia notar mais a presença dele no grupo, afinal, ela se deu conta da ausência...

Descobrimos que alguns bebês demonstraram estar em relação com alguns adultos da creche, além de mostrarem uma capacidade de discriminar as relações de cuidado. Verificouse que os bebês olhavam e sorriam para as pessoas que cuidavam, alguns eram seletivos, desconfiados, o que poderia, talvez, indicar um certo estranhamento, em relação as pessoas que eles não conheciam ou tinham pouco contato. O que novamente indica que eles pareciam capazes de discriminar as relações de cuidados das demais relações (Amanda, Márcio, Heloísa).

Com outros bebês, notamos a ausência de contatos com os adultos. E essa ausência se apresentava de forma diferente entre os bebês. Em Amanda, observamos que a falta de contato parecia se relacionar com a ausência de cuidados por parte das profissionais, ela necessitava de cuidados diferentes do que lhe estava sendo oferecido, isso pode ser pensado pelo choro não atendido e os comportamentos autoestimulatórios, uma tentativa de oferecer a si mesma os cuidados que parecia necessitar.

Lucas e Márcio eram crianças com menor nível de solicitação dos adultos, eles ficavam a maior parte do tempo, se deslocando pela sala ou entretidos com algum brinquedo, talvez se pudesse pensar que demonstravam certa passividade em buscar pelo contato, talvez, uma certa inibição. Mesmo entre eles, havia diferenças, porque Márcio se mantinha em contato pelo olhar curioso e atento para o ambiente, enquanto Lucas parecia mais desligado do ambiente.

Roberto (5 meses) era um bebê bastante novo e ainda sem condições de domínio do próprio corpo, nem para segurar sua mamadeira, nem para se locomover em busca de contato. Também era um bebê que solicitava pouco, passava boa parte do tempo sentando em cadeirinhas ou deitado no colchonete, olhando o que acontecia em sua volta, poucas vezes chorava. O que poderia ser pensado como passividade, nos parece parte de seu amadurecimento, tendo em vista que era um bebê com poucos recursos desenvolvidos, necessitando que as profissionais viessem ao encontro dele, o auxiliasse em suas necessidades de cuidado. 
As meninas Paula, Heloísa, Juliana e Laura se mostravam mais ativas no contato com os adultos, demonstravam utilizar dos recursos que dispunham para receberem o atendimento de que precisavam. Paula se colocava em ação chorando e esperneando até que uma das profissionais fosse ao encontro dela para ver o que acontecia. Heloísa também demonstrava saber chamar a atenção para si, esticando os bracinhos na direção dos adultos, chorando e gritando, assim como Laura, que também chorava. Juliana sabia o que queria e como obter, procurando as profissionais, especialmente a preferida para atendê-la.

É possível ver que encontramos muitas diferenças entre as crianças, desde seus modos de existir, pensando suas formas de comunicação, apropriação e uso do próprio corpo, as formas de ocupar o espaço e estar em relação tanto com as pessoas quanto com o ambiente, o que nos possibilitou conhecer as singularidades dos bebês e identificar algumas das necessidades nas relações de cuidados entre eles e as profissionais.

Voltaremos a isso, mas, antes, pousaremos nosso olhar nas discussões sobre as profissionais.

\subsubsection{As Educadoras e Professoras: as relações de cuidados com os bebês}

No cenário das creches encontramos profissionais mais disponíveis para o contato com a pesquisadora (Elisa, Vânia e Camila). Logo elas mostraram que acompanhavam os bebês, pareciam saber sobre eles, conheciam as histórias dos bebês e quem eram eles. Essas profissionais também deixavam aparecer afeição pelas crianças e se mostravam ligadas a elas mais facilmente do que as demais.

Além disso, parece que as profissionais que eram mais disponíveis para conversar, também mostravam mais disponibilidade com as crianças.

Outras profissionais se mostraram mais difíceis no início, apresentando-se menos disponíveis para o contato com a pesquisadora, menos acessíveis para conversarem, revelando maior desconfiança e hostilidade. Estas também demonstravam menor disponibilidade com as crianças, pelo menos a princípio.... 
Iniciamos mostrando que aparecem três tipos de relações entre preocupação e ação na direção de resolver a situação ou problema em curso.

A relação do primeiro tipo se referia a identificação pela profissional de um problema a ser resolvido. A preocupação era verbalizada em relação à criança e uma ação era realizada para atender a necessidade da criança ou a situação relativa a ela. Um segundo tipo, as profissionais verbalizavam a preocupação em relação a criança ou situação e não realizavam ação em direção à criança para resolver. Era apenas uma fala desprovida de ação....

E o último tipo se referia a um estado de não preocupação com a criança e a situação dela e sim, com a pesquisadora e sua presença na cena. Essas diferenças marcavam de forma significativa as relações de cuidados que aconteciam na creche.

De forma geral, constatamos que havia pouco contato corporal com os bebês por parte das profissionais, elas não costumavam pegar ao colo quando eles choravam ou apresentavam outras necessidades, como a alimentação, por exemplo.

Por contato corporal estamos denominando todos os gestos direcionados a criança e seu corpo, sendo assim, tocar, acariciar, beijar, abraçar, pegar ao colo, olhar, conversar, brincar, ninar, aconchegar, consolar, ou seja, ações que promovam o contato do bebê com o seu próprio corpo e com o corpo de outro. Realizações que proponham um tipo de contato entre duas pessoas, uma interação entre dois corpos vivos.

Além disso, compreendiam que segurar os bebês ao colo era algo que parecia ser uma ação feita pela família e, talvez, deveria ser desestimulada na creche. Ouvia-se em seus discursos: "A mãe disse que ele gosta de um colinho!" ou "Em casa ele está acostumado ficar o tempo todo no colo". Assim, o choro também era visto como algo que pertencia ao estar na creche, algo necessário para que os bebês percebessem que eles não estavam em casa, parecia ser um divisor de águas, um modo de diferenciar a creche e a família, os cuidados maternos e os cuidados das profissionais.

Ao mesmo tempo, permitir que os bebês chorassem por longos períodos de tempo sem atendimento também parecia ser algo insuportável para as educadoras. Elas pareciam perceber o choro como algo que elas precisavam se afastar, como algo insalubre. Em outro texto que produzimos sobre as creches dissemos que o choro parecia para elas causa de sofrimento. 


\begin{abstract}
"Quando as crianças estavam chorando muito, as professoras queriam sair da sala para tomar café, descansar, falavam que os choros constantes eram, para elas, más condições de trabalho. As condições pareciam mesmo penosas para as professoras, porém quem gritava eram os bebês" (MENEZES; MORATTI, 2014, p.178).
\end{abstract}

Ainda, nesse mesmo sentido, havia indícios que as profissionais não dispunham de recursos pessoais para fazer parar aqueles choros, parecia que elas tinham desistido. Nota-se o reaparecimento da desistência, agora com as profissionais.

Se voltarmos as questões dos tipos de preocupações que apareceram em análise, podemos pensar que o choro dos bebês era algo identificado como um problema para elas, não para os bebês. As profissionais percebiam que o choro dos bebês poderia dizer de alguma necessidade, como ser seguro ao colo, como elas retratavam que parecia acontecer na casa dos bebês.

Vê-se que as profissionais identificavam a situação, mas, não demonstravam ações na direção de resolver aqueles choros, elas os deixavam chorando e fugiam do ambiente... Essa era a ação, deixar chorando e evitar ou sair!

Dessa forma, os contatos corporais com os bebês ficavam restritos aos momentos de cuidados com alimentação e trocas, contudo, esses cuidados eram pouco espontâneos, sobretudo, no início, que observamos contatos de cuidados mecânicos e automáticos, sem relação com os bebês.

Também parece somar-se a isso a percepção de que algumas profissionais demonstravam pouca disponibilidade para acompanhar o ritmo dos bebês, as ações se voltavam a desenvolver autonomia neles, queriam emancipar os bebês dos cuidados, o que parecia revelar o não reconhecimento das reais capacidades dos bebês, bem como o caráter imprescindível das relações de cuidados por um adulto.

Com isso, verificamos que em um primeiro momento as profissionais não atendiam as necessidades dos bebês de forma a oferecem a possibilidade de alívio, conforto, relaxamento, enfim, ir ao encontro das necessidades que poderiam gerar bem-estar físico e psíquico. De início, as profissionais estavam mais voltadas para o atendimento das necessidades apenas de ordem física ou fisiológica. Elas não pareciam olhar para os bebês como pessoas...

Nessa direção, notamos que não apenas os contatos corporais com os bebês eram escassos, as profissionais também demonstravam conhecer pouco os bebês, principalmente no 
início do acompanhamento. Aos poucos, foram revelando que conheciam as crianças e mostrando que podiam se ligar ou estavam ligadas a elas, conforme tentaremos mostrar mais adiante.

\section{“O ambiente e suas temperaturas..."}

Encontramos algumas diferenças das profissionais no modo de estar na creche e, sobretudo, no modo como estabeleciam as relações de cuidados com os bebês.

Observamos que havia profissionais com um modo de contato que predominava a disciplina, a impaciência e a irritabilidade na relação de cuidados com os bebês. E, algumas, chegavam a hostilidade no contato com os bebês, como vimos, gritavam, propagavam "broncas", isolavam ou repreendiam as ações dos bebês.

Essas profissionais apresentavam pouca disponibilidade para estar com os bebês. E ações do tipo retirar, isolar, insistir, enfim, que envolviam o uso de força, geravam imposições aos bebês e restrições a seus gestos e suas necessidades, essas ações parecem corroborar com essa hipótese.

Havia quem, embora pudesse assumir uma posição mais disciplinadora, a realizasse para buscar emancipar os bebês, desestimular a dependência com a qual se defrontava diariamente.

Contrastando com esse ambiente em que a dureza se apresenta como marca inicial, verificamos outras formas de contatos existentes nesse ambiente, algumas relações de cuidados que se destacaram pela delicadeza e dedicação com que se estabeleceram.

Observamos que algumas profissionais demonstraram suavidade, delicadeza, paciência e ritmo ao oferecem cuidados aos bebês. Encontramos educadoras que olhavam para os bebês e suas próprias necessidades, buscando ir ao encontro do bebê.

Essas profissionais se mostravam disponíveis para se relacionarem com os bebês de maneira a se adaptarem a eles em suas possibilidades e expressões. Note-se que elas não procuravam adaptar os bebês às necessidades do ambiente, elas pareciam reconhecer a condição de dependência do bebê. 
Retomamos a cena de Camila e Paula (cena 1), despertar o bebê de seu sono é uma necessidade da profissional, uma necessidade de sua função na creche, tendo em vista o horário de saída do bebê. E vimos que ela o faz olhando Paula como uma pessoa, respeitando o ritmo ao acordá-la, tocando o corpo com suavidade, ela vai comunicando a criança sobre suas ações, ela se apresenta para Paula e aguarda os sinais da criança para avançar em suas ações. Vê-se nessa ocasião que a profissional procura estabelecer uma comunicação com a criança e, somente a partir disso, ela completa a ação de despertar e pegar a criança ao colo.

Algumas das profissionais revelaram disponibilidade para estar com as crianças de modo a estabelecer relações de cuidados que consideravam os recursos existentes nos bebês, levando em conta a capacidade deles para assimilar os acontecimentos, as situações, buscando facilitar que o bebê acompanhasse as rotinas da creche, mas gradativamente.

Essas profissionais também demostraram a capacidade de acompanhar os bebês e conhecê-los, oferecer atenção as necessidades, acolher os bebês nos momentos em que precisassem de conforto, alívio, aconchego, brincadeiras etc.

\section{Como as profissionais apareciam no exercício da função?}

Inicialmente, verificamos que elas não apareciam. As profissionais ofereciam apenas os cuidados básicos aos bebês, particularmente os cuidados de alimentação e higiene. Notamos que elas não acompanham os bebês, não olhavam, não percebiam, não notavam a presença, não notavam os gestos. Nesse sentido, as profissionais apareciam pela ausência nas relações com os bebês.

Isso complementa o que discutimos em relação ao não atendimento as comunicações dos bebês (choros, gestos, gritos, solicitações etc.) e os escassos momentos de estabelecimento de contato corporal com os bebês.

As profissionais, algumas vezes, demonstravam saber o que acontecia com os bebês, principalmente, quando eles choravam, se recusavam a comer etc., mas não ofereciam nenhuma solução alternativa ao que estava acontecendo com eles, bem como algumas não se apresentavam disponíveis a essas tarefas. 
Elas não revelavam compreender a natureza da dependência dos bebês, o que também se colocava como um obstáculo a extensão de ações ao acolhimento e os cuidados com eles. Não bastava, ou melhor, não se tratava apenas identificar as necessidades dos bebês, mas, sobretudo, apresentar a disposição para alterar a situação, para propor alternativas que auxiliasse as crianças.

Ao refletir com nossos pressupostos, pensávamos que apenas diante da disponibilidade a estar com os bebês, ou melhor dizendo, de uma possibilidade de se identificar com o bebê, seria possível reconhecer as necessidades. No entanto, o que vimos, é que mesmo diante da indisponibilidade para a relação com os bebês, havia quem identificasse as necessidades, mas isso não garantia o atendimento. Como estamos percebendo, parece necessário estar, sobretudo, disponível para cuidar, para construir uma relação de cuidados.

\subsubsection{Entre observações, imprevistos e conversas: a pesquisadora}

A primeira ação da pesquisadora ao chegar nas creches foi observar. E ao que estamos mostrando, nossas observações iniciais diziam respeito ao choro dos bebês. $\mathrm{O}$ ambiente da creche era barulhento, marcado pela intensidade e quantidade de bebês chorando. Nossas observações avançaram e percebemos que esses choros faziam sentido dentro do contexto da creche, eles eram (re)clamações, pedidos que vinham de todos os lados e de diferentes formas.

Notamos que os bebês choravam de fazer "pocinhas", o que se revelou uma medida do tempo na creche, do tempo que passavam os bebês sem auxílio dos adultos, no mesmo gesto, também circunscrevia como o adulto aparecia por sua ausência, o que denunciava a falta de cuidados a que se encontravam os bebês. Mostravam o desamparo que existia naquele ambiente.

Diante desse cenário, a pesquisadora passou a buscar pelas profissionais. Realizou aproximações com objetivo de estabelecer relações com elas, conhecer mais a rotina da creche e seu funcionamento e, principalmente, conhecer as educadoras e os bebês.

A aproximação aconteceu de diferentes maneiras, algumas profissionais permitiam a aproximação, se dispunham a conversar, a explicar sobre a creche, a falar das rotinas, a falar de 
si e sobre os bebês. Outras, aproximar-se requereu mais tempo e mais investimento, era preciso fazer movimentos de avanços e recuos até que uma relação de maior confiança se firmasse.

Estabelecidas as devidas aproximações e relações com as educadoras, começamos um trabalho conjunto. Isso consistia em acompanhar algumas atividades da rotina da creche, com o tempo, a pesquisadora passou a auxiliar nessas tarefas com objetivo de conversar com as profissionais sobre os bebês.

Desse modo, enquanto a pesquisadora fazia junto com as profissionais as atividades diárias, havia conversas sobre os bebês, nessas ocasiões, a pesquisadora perguntava pelos bebês, queria saber como eram, por que choravam, como era o sono, como se alimentavam, se havia comunicação entre eles e as educadoras, se brincavam etc.

Além disso, a pesquisadora também comentava com as profissionais o que observava e reparava na relação com os bebês, o que sentia falta, o que notava que faziam, suas preferências por uma ou outra profissional.

Verificou-se que, conforme as conversas avançavam e se tornavam parte das visitas de acompanhamento nas creches, algumas profissionais passaram a sentir-se mais à vontade, seguras, aguardavam a presença da pesquisadora e contavam com as conversas.

Destacamos que ao mostrar as profissionais o que a pesquisadora notava ou não na relação com os bebês, as profissionais passaram a revelar o que conheciam sobre as crianças, elas relatavam para a pesquisadora como os bebês gostavam de ser cuidados.

Isso pareceu ter algum efeito sobre a atenção que as profissionais mantinham com os bebês, elas passaram a olhar na direção deles, pareciam cada vez mais, conhecer os bebês, saber sobre eles. E, nas conversas, diante do apontamento da pesquisadora para aspectos que não observava nos bebês, elas acrescentavam elementos que a pesquisadora não conhecia, ressaltavam as particularidades dos bebês.

Dessa forma, elas ampliavam o conhecimento da pesquisadora sobre os bebês e se voltavam na direção deles, pouco a pouco, ampliando as relações de cuidados com os bebês.

Verificamos que as conversas nas creches, durante todo o acompanhamento, continuaram circulando entre a pesquisadora e as profissionais, também circulavam entre as profissionais e as mães das crianças e entre as próprias profissionais. Parece que se introduziu um espaço para conversar sobre os bebês nas creches. Houve multiplicação das conversas nas 
diferentes direções, inclusive na direção dos bebês, pois as educadoras passaram a conversar com as crianças durante os cuidados com elas.

Quando a pesquisadora, durante as conversas, fez apontamentos sobre o que via nas crianças em relação às profissionais, sobretudo, destacando a relação de afeto da criança na direção delas, parece ter aberto um espaço para o campo das relações amorosas entre elas e os bebês.

Contudo, nem tudo era amor, havia também o ódio.

Nas relações mais difíceis entre a pesquisadora e as profissionais e entre estas e os bebês, houve muita tensão. Nas cenas em que a relação das profissionais com os bebês foi marcada pela falta de cuidados e pelas ações pautadas na força, ou seja, em ações agressivas, houve muito susto. Haja visto que a pesquisadora se assustou em três ocasiões, sendo que, em duas delas, ficou paralisada por efeito das ações das profissionais com os bebês.

Essas situações que despertaram medo na pesquisadora, talvez, pudessem assustar ou causar medo também aos bebês, a menos que eles estivessem "acostumados" a essas situações, o que de qualquer modo não seria um indicativo saudável. O que poderia sinalizar a instalação de algumas detenções ao processo de desenvolvimento psíquico dos bebês.

Lembramos uma dessas ocasiões que a pesquisadora, como efeito da ação da profissional, permaneceu paralisada, a ação da criança foi buscar refúgio no colo desta e iniciar seu gesto autoestimulatório de desligamento em direção ao ambiente. O que talvez indicasse os efeitos da agressividade sobre os bebês, isso, claro, sem contar a criança que sofreu a ação.

Novas ações de intervenção no acompanhamento se fizeram necessárias, pensar sobre as observações e as intervenções realizadas junto as profissionais e os bebês foi importante para o desenvolvimento delas. Assim, pensou-se primeiramente em intensificar o acompanhamento com as essas profissionais, isso significava, observar como elas se apresentavam a cada visita e compartilhar das tarefas com elas, estar e fazer junto.

Desse modo, procurou-se fazer uma adaptação ao modo de estar nas relações das profissionais, isso exigiu ações de adiamento, de espera, pois quando se identificava grande tensionamento nas relações com os bebês ou com a pesquisadora, esta intervia ajudando com as tarefas e conversando com as profissionais sobre as mesmas e sobre as dificuldades que apareciam, que elas identificavam etc. Quando a tensão se dissipava, as conversas sobre os bebês ganhavam espaço e se estabeleciam em outras bases, ou seja, menos agressivas. 
No percurso, observamos que a agressividade cedeu tanto em relação à pesquisadora quanto nas relações com os bebês.

Ressaltamos que essas intervenções se alargaram no tempo, ações de avanços e recuos se operaram até a oportunidade se abrir. Que oportunidade? A oportunidade de realizar uma intervenção que parasse as profissionais em suas ações agressivas.

Retornemos a cena com Raimunda, aquela ocasião foi a terceira situação em que a pesquisadora se deparava com o imprevisto, com acontecimentos que geravam susto... Observamos ainda que, essa cena, dada a intensidade da ocorrência, tanto pesquisadora quanto a outra educadora presente em cena direcionaram uma ação em prol da criança.

Nesse movimento de ação em direção da criança, a pesquisadora rompeu com a inércia das cenas anteriores, agiu frente a agressividade de Raimunda. Como efeito, paralisou a educadora que ficou imóvel em cena, ficou sem ação....

Temos assim, a Imobilidade da pesquisadora VERSUS a Imobilidade da profissional, vê-se que a cena se inverte. E como se inverte? Ela se inverte pelo próprio ódio. Explicamos. Como é possível parar uma ação de tamanha força? Ao apresentar a ação de cuidados com o bebê, a pesquisadora se posicionou frente a agressividade da profissional. Ter partido em socorro à criança produziu como efeito a imobilidade da profissional, ela se assustou, era imprevisto ver a pesquisadora (re)agir!

E foi através desse mesmo ódio que vimos desabrochar o amor, ou melhor, o início de uma relação de cuidados....

\subsubsection{A creche como instituição}

Considerando o acompanhamento nas creches e as análises das cenas, destacamos dois aspectos que aparecem como interface desse ambiente: a mudança de ciclos realizadas com os bebês e a mudanças de profissionais. Verificamos que aconteceram as duas modalidades de mudanças, sendo que os bebês (creche A) mudavam de ciclos periodicamente e, ao mesmo tempo, mudavam de espaço físico, mudavam de educadoras e de colegas de turma. 
Outra modalidade contemplava a mudança dos professores dentro do mesmo ciclo, as educadoras ou professoras se afastavam da creche por problemas de saúde ou por desligamento do trabalho, o que ocasionava a substituição temporária ou definitiva das profissionais.

Diante dessas mudanças, os bebês eram lançados em situações novas, na maioria das vezes, sem nenhum tipo de adaptação ou preparo. Essas mudanças constituíam para os bebês alterações muito bruscas de suas rotinas, de seu ambiente, quebra de relações com as profissionais e com outras crianças. O que implicava com que crianças tivessem que lidar com as mudanças com seus parcos recursos, como vimos nos comportamentos autoestimulatórios de Amanda ou no desligamento dos contatos com as pessoas como fazia Lucas.

Esses tipos de alterações das rotinas, favorece a quebra da regularidade nos contatos e nos cuidados os bebês, essas mudanças, geradas repetidas vezes, sem a experiência de adaptação gradual dos bebês, podem ocasionar rupturas na continuidade do desenvolvimento psíquico dos bebês, o que pode trazer entraves ou problemas.

\subsubsection{Das aberturas possíveis: os efeitos do acompanhamento nas creches}

\section{Ações e "conversações"}

As análises mostraram que uma das principais ações realizadas pela pesquisadora na creche foi estabelecer conversas com as profissionais sobre os bebês. Ao longo do acompanhamento, verificamos que introduzimos as conversas para falar sobre os bebês e constatamos que se criaram campos de conversas com as profissionais.

Nesses campos de conversas, elas passaram a falar mais sobre os bebês entre elas, com as mães e com a pesquisadora. A partir dessas ações de circulação das conversas as profissionais revelavam mais informações, situações e histórias sobre os bebês, ensinavam sobre eles, comentavam como eram, do que gostavam e não gostavam, como dormiam, como preferiam 
ser alimentados, qual mamadeira preferida, deixavam escapar quais eram os bebês amados etc., enfim, elas passaram a trazer e demonstrar mais conhecimentos sobre os bebês.

Vimos as ações da educadora Rosa, por exemplo, que convidou, por duas vezes, a pesquisadora para ser acompanhada em relação de cuidados com duas crianças, nessas ocasiões notamos que esse campo de conversas, também proporcionou espaço para as educadoras serem vistas e ouvidas, como veremos adiante.

Destacamos que ao notar a criação do campo de conversa, verificamos que as profissionais estavam trazendo mais informações direto das fontes. O que significa? Elas estavam acompanhando os bebês, estavam prestando atenção, notando, reparando, olhando para eles, estavam sabendo mais sobre os bebês. As profissionais estavam conhecendo os bebês e esse conhecimento mostrava, ao mesmo tempo, que elas estavam em contato com eles, elas estavam estabelecendo relações de cuidados com os bebês.

Parece que, ao olhar os bebês, buscar conhecê-los e mostrar interesse por eles a pesquisadora despertou a atenção das profissionais. Ao procurar introduzir as conversas sobre os bebês nas relações com as profissionais, observamos que introduzimos os bebês no horizonte das profissionais.

\section{Em busca dos bebês....}

Com a introdução dos bebês no horizonte das profissionais verificamos que elas buscavam pelas crianças. Elas notavam seus choros, procuravam as crianças pelos cantinhos, notavam suas ausências, chamavam os bebês por seus nomes.

Viu-se que as profissionais se aproximaram dos bebês, à medida que passaram a buscar por eles, o choro na creche diminuiu, as crianças estavam mais juntas, ficavam mais concentradas no centro das salas e perto uma das outras, acompanhadas da presença de uma das profissionais. 
Com um olhar mais direcionado para as crianças, as profissionais começaram a conversar com os bebês, elas falavam, cantavam, faziam pequenas brincadeiras com eles durante os cuidados.

Essa busca pelas crianças, proporcionou um melhor acompanhamento dos bebês, pois a presença deles passou a ser notada, percebida. As professoras, agora, estavam olhando para as crianças, notou-se mais entrega, envolvimento delas com os bebês, observamos que elas passaram a ir ao encontro deles e das necessidades que apresentavam.

Com isso, os bebês ganhavam mais colo quando choravam, ganhavam colo na hora das mamadeiras, o som do choro foi sendo substituído pelas conversas entre as profissionais e os bebês, sim, porque eles se olhavam, se viam, se acompanhavam e se comunicavam. Estabeleceu-se uma relação de reciprocidade entre eles, havia troca e comunicação.

A possibilidade de comunicação sempre esteve no ambiente, mas era preciso facilitar sua realização. Os bebês estavam lá, chorando e esperneando com seus corpinhos, alguns mais fortes, outros mais frágeis, alguns com mais corpo, outros com menos, alguns silenciosos, outros pelos cantinhos, mas todos se comunicando o tempo todo, na esperança de serem vistos.

A ação da pesquisadora propiciou visibilidade aos bebês, enquanto, se relacionava com as educadoras, conversava com elas, fazia junto, elas começaram a ver os bebês, eles ganharam existência na creche. Parece que as ações da pesquisadora na relação com as profissionais favoreceram a mudança na direção do olhar, pois o olhar se dirigiu para os bebês.

É em busca dos bebês que a relação de cuidados começa... Ir ao encontro dos bebês é o primeiro cuidado!

\section{A Visibilidade para os bebês na creche}

Ao alcançar a visibilidade os bebês ganharam existência na relação com as profissionais, agora eles podiam existir na creche.

A título de esclarecimento, existir, nesse contexto, pode significar ser visto, receber cuidados de acordo com as necessidades comunicadas. Ser cuidado de maneira a ter 
experiências de regularidade e continuidade dos contatos e dos cuidados, ou seja, não ser deixado em situações as quais não se tem condições de lidar ou ter interrompidos esses cuidados.

A existência dos bebês pode ser observada em várias direções, ressaltamos a entoação dos nomes das crianças nas salas, a possibilidade de serem buscados pelos adultos, a instalação da comunicação entre eles, que mostra o desenvolvimento de maior proximidade e intimidade entre as profissionais e os bebês.

Houve aproximação e desenvolvimento de maior contato entre as próprias crianças, estimuladas pelos adultos a estarem juntas, a compartilharem da presença uns dos outros. Estabeleceu-se o contato corpo a corpo de profissionais com os bebês e entre os próprios bebês.

Observamos que as profissionais estavam em contato corporal com as crianças. A creche foi ganhando corpo...

\section{Habitar a creche, habitar o corpo}

Observamos que dada a visibilidade dos bebês as relações de cuidados se alteraram de forma sensível, particularmente com o estabelecimento de uma relação entre as profissionais e os bebês que é tecida pelo corpo. O corpo de ambos compõe a relação de cuidados na creche, mantém o contato, uma vez que é o adulto com seu corpo que acolhe, reúne, segura, limpa, olha e manuseia o corpo do bebê.

Começa a nascer uma regularidade dos cuidados com o corpo dos bebês que se estendem para além dos cuidados físicos. O manuseio com corpo dos bebês durante as trocas passa a ser mais espontâneo, acompanhado de olhares, conversas, reciprocidade, pequenas brincadeiras. Há maior disponibilidade de sustentar os bebês ao colo, parece que o colo foi deixando de ser espaço somente do âmbito familiar. Pegar os bebês ao colo passa ser outro cuidado exercido pelas profissionais das creches.

E o que acontece? 
Os bebês ganham corpo na creche. Todos esses contatos de manejo com o corpo dos bebês favoreceram que aos poucos, todos os bebês desenvolvessem maior sentido de corporeidade. Esses cuidados corporais mais regulares e contínuos proporcionaram aos bebês, experiências com seus corpos, puderam vivenciar o corpo como um espaço, um espaço que é deles, que eles habitam.

Com isso, notamos que os bebês apresentaram mudanças na forma de comunicação com o ambiente, alguns alcançaram a condição de chamar pelas profissionais, outros conquistaram mais condições de movimentar seu próprio corpo, favorecendo o estabelecimento de contato, uma vez que podiam mudar de posição para localizar os adultos com o olhar, podiam chorar mais alto ou gritar e, mesmo, se locomover e ir ao encontro dos adultos.

Nessa direção, ganhar corpo é conquistar capacidade de chamar, solicitar ajuda, ampliar a capacidade de comunicação com o ambiente. É importante para favorecer que os bebês continuem o movimento de ir em busca, ir em direção a algo, contribuindo para o desenvolvimento dos bebês e pode proporcionar a ampliação das capacidades crescentes dos bebês.

Observamos que esses cuidados fortaleceram os bebês, exemplos desses cuidados foram vistos com Rosa e Vânia ao ninarem os bebês, ao reunir os bebês e seus corpos e embalar na circularidade de seus braços.

Vê-se a potência desses cuidados no desenvolvimento de Amanda na relação com Vânia. Ela passou a chorar de modo mais forte, mais audível, também ganhou força em seus movimentos, conquistou a capacidade de se mover e, posteriormente, de deslocar-se atrás de Vânia.

Como resultado, destacamos a modificação no comportamento dos bebês, particularmente, notamos a recuperação das crianças com o estabelecimento das relações de cuidados, inicialmente oferecidos pela pesquisadora e, posteriormente, totalmente encampados pelas profissionais

Assim, habitar o corpo é conquistar a possibilidade de habitar a creche, de forma que os bebês mostraram o quanto se beneficiaram da visibilidade, conquistaram também a existência no corpo e, a partir dele, se direcionaram ainda mais para o espaço. E as profissionais? Elas também ganharam corpo ao estabelecerem essa relação de cuidados, elas também passaram a existir, especialmente para os bebês! 


\section{Se eu fosse um peixinho e soubesse nadar eu buscava os bebês lá no fundo do mar...}

Os momentos para as brincadeiras era algo possível na creche B. Desde o começo do acompanhamento, observamos que brincar com as crianças integrava a relação de cuidados com os bebês. Havia tempo e os espaços para as brincadeiras, para o aconchego das crianças, para cantar com elas, para fazer massagens etc.

Todos os dias havia música para as crianças, tocadas ou cantadas pelas professoras para as crianças, eram momentos para tocar, abraçar, cantar, brincar, olhar, sentar e deitar no colo das professoras.

Já, na creche A, as brincadeiras eram "produto raro". As análises indicaram que as brincadeiras começaram a existir com a chegada dos cuidados, com estes, as profissionais foram flagradas em momentos lúdicos com os bebês.

Observou-se que as educadoras não só começaram a brincar com os bebês, bem como, passaram a propor brincadeiras, oferecer brinquedos, apoiar e facilitar que as crianças brincassem juntas.

O brincar se configurou como outro cuidado que ganhou existência na creche, além de proporcionarem experiências prazerosas no contato com os bebês, auxiliaram na ampliação das vivências e do desenvolvimento dos bebês. O brincar auxiliou no estabelecimento de outras formas de contato.

O mais imediato: o brincar trouxe para os bebês possibilidade de experiências com objetos diferentes, fossem eles brinquedos ou não, o que enriqueceu o uso do espaço pelos bebês nas creches. Outro dado, o que parece mais importante: o brincar aproximou as crianças entre si, criou espaço de convivência entre os bebês.

Notamos ainda, que o uso de brinquedos e a facilitação da convivência entre os bebês, também inaugurou um modo de estar na creche, que permitiu as profissionais realizarem alguns afastamentos dos bebês. Criou-se a possibilidade de distanciamento entre os bebês e as profissionais dentro do espaço, as crianças suportavam ficar sozinhas com brinquedos ou próximas a outras crianças, por um intervalo de tempo, enquanto as profissionais cuidavam de outras crianças, por exemplo. 
Podemos pensar como as possibilidades de brincar permitiram o alargamento das relações entre as profissionais e os bebês, particularmente no que diz respeito as relações amorosas.

\section{O Segredo: o lugar do afeto}

Não por acaso, o amor ficou para o final. As relações entre os bebês e as profissionais era marcada por afetos. Visível era a direção dos afetos dos bebês, não havia dúvidas para que lado eles se encaminhavam, bastava acompanhar os gestos ou os olhinhos atentos a fitar o alvo.

Sim, deles sabia-se a direção! Não tão fácil assim a identificação, ou melhor, a manifestação dos afetos e da direção deles nos adultos.

Verificamos que, aos poucos a entrega, a disponibilidade, o envolvimento e a liberdade com os bebês, principalmente, entre as profissionais que se mostraram mais resistentes e distantes ao contato, mais hostis, enfim tiveram algum espaço.

Inicialmente, o amor pareceu tímido, desconfiado, aparecia pelos cantos. É só lembrar de Rosa se escondendo num cantinho para ninar João, um dos seus bebês preferidos. A mesma Rosa, sequestrando Laura do berçário II ${ }^{24}$ para ter um tempinho com ela, ou, ainda, Vânia, que fotografava os bebês antes das mudanças de ciclos.

Interessante pensar que esse tema venha logo após o brincar, pois a relação amorosa de algumas das profissionais com os bebês ganhou destaque nos momentos de brincadeira. Nessa hora, vimos como elas ficavam a vontade com as crianças, como a satisfação e a afeição apareciam juntas, tornando o ato de brincar um divertimento para a dupla.

Nossas análises permitiram perceber que mostrar afeição pelos bebês vinha depois de longo percurso de acompanhamento, vinha quase no final, e as conversas sobre esse amor, apareceu de modo secreto, era o mais bem guardado. Eles também moravam nas lembranças...

\footnotetext{
${ }^{24}$ Sobre isso, ver o capítulo "O contexto das creches" - creche A.
} 
Recuperamos as conversas com Rosa e Raimunda tão diferentes entre si e tão próximas em seus movimentos de guardar seus afetos. Vejamos...

Rosa ao convidar a pesquisadora para ver o banho de Juliana (“docinho”) começa mostrando o banho, comentando esse cuidado e falando de sua satisfação, no mesmo ato que realizava o cuidado. Diante das relações de cuidado com Juliana, uma criança amada por ela e da relação com a pesquisadora que nessa altura já havia alçado a confiabilidade, revela-se a ligação amorosa com algumas crianças e as marcas dessas relações em suas lembranças.

Até esse momento, as lembranças pareciam ser o lugar do amor, só lá poderia existir! A afeição pelos bebês era algo secreto, mantido em silêncio...

Às vezes, aparecia como algo proibido, que precisava ser feito às escondidas, como era nos momentos de "sequestros amorosos" das crianças de outras salas.

Com Raimunda, era diferente, faz lembrar a poesia "Segredo",25.

"A poesia é incomunicável.

Fique quieto no seu canto.

Não ame".

Raimunda em suas ações parecia recitar esses versos incansavelmente, pois sua hostilidade e resistência ao estabelecimento de uma relação com a pesquisadora e com as crianças que não fosse pautada por agressividade, não parecia possível.

A afeição não era comunicada, as ações de Raimunda se direcionavam ao afastamento das pessoas, elas se destinavam a criar distâncias. Caminho longo até o estabelecimento de uma relação de liberdade e confiança entre educadora e pesquisadora. Quando se abriu, o campo da relação e a comunicação trouxe a oportunidade de falar sobre o que acontecia nas relações com a pesquisadora e com os bebês, a possibilidade de aproximação de Raimunda com os bebês e a demonstração de afeição apareceu.

Vimos, o estabelecimento de relações de cuidado com as crianças surgirem e, principalmente, elas estavam livres da hostilidade, havia frestas para o amor e para os cuidados.

\footnotetext{
${ }^{25}$ Poesia "Segredo" de Carlos Drummomd de Andrade.
} 


\section{A Visibilidade para as profissionais na creche}

O acompanhamento das relações de cuidados entre as profissionais e os bebês teve como efeito das ações da pesquisadora a criação de um espaço de visibilidade para os bebês e suas existências nas creches. Contudo, as análises apontaram que a criação da visibilidade para os bebês, também abriu um campo de visibilidade para as profissionais. Inicialmente, a própria inserção da pesquisadora no contexto da creche abriu a possibilidade para tal, o que, também, gerou algumas (re)ações nas profissionais, como medo, insegurança, distanciamentos e hostilidades.

Porém, a visibilidade que se mostrou mais importante veio com o estabelecimento das relações de cuidados com os bebês, pois é no momento que elas notam e levam em consideração a existência dos bebês, as profissionais também assumem visibilidade e existência.

As profissionais podiam, então, ser vistas com os bebês, elas estavam em relação com eles. E ser acompanhada e vista pela pesquisadora foi incorporado também pelas educadoras, que contavam com a presença e o olhar da pesquisadora.

A expressão dessa visibilidade pode ser demonstrada nos convites das educadoras para que a pesquisadora acompanhasse suas ações. Rosa aparece em dois momentos diferentes, exercitando o campo de visibilidade a pedido dela.

Embora, todas as profissionais ocupassem esse espaço de visibilidade com as crianças e a pesquisadora, é Raimunda, novamente, quem ganha visibilidade pela diferença.

A visibilidade e existência de Raimunda se deu pela força. É principalmente pelas ações de agressividade que ela configurou o campo de visibilidade. E o uso desse campo pela ira, precisou ser realizado pela pesquisadora para que a profissional não só alcançasse a visibilidade e a existência, mas, fundamentalmente, que ela pudesse reconhecer o modo como essa existência era vivida na creche. Particularmente, como essa forma de existência furiosa era vivida na relação com os bebês, inviabilizando as relações de cuidados.

Observamos que ao ser vista e ouvida em suas (re)clamações, bem como ao poder conversar sobre essas relações, a profissional parece ter alcançado a possibilidade de ouvir e refletir, o que alterou as relações com os bebês, permitindo que ela começasse a estabelecer relações de cuidados mais saudáveis com eles. Nasceu uma possiblidade de criar novas relações 
e nelas, incluir os cuidados. Essa novidade parece não ter sido aproveitada apenas pelos bebês, como mostramos em nossas análises (cena 6), mas, principalmente, pela própria profissional que demonstrava que cuidar parecia ter se tornado uma relação mais leve, mais simples! Acima de tudo, parecia possível. 


\section{CONSIDERAÇÕES FINAIS}

Estar na creche como pesquisadora promoveu uma experiência que foi apreendida pelos diversos os sentidos: visão, tato, olfato, audição e, até, o paladar. Sim, às vezes, chegavam até a pesquisadora algumas comidinhas.

Começamos essa conclusão brincando para dizer como essa experiência impactou na pesquisadora, muitas inquietações existiram nesse percurso que experimentadas pelos sentidos, fizeram a pesquisadora sentir. Há a expectativa de termos aproximado o leitor de nossas experiências e ter compartilhado como sentimos e quais sentidos encontramos.

Duas creches, várias professoras e muitos bebês, experiências recolhidas com o acompanhamento nas creches. Mostramos, nos resultados, como cada uma das creches, como instituição, possuía sua singularidade, com organização e modo de funcionamento específicos.

O elemento comum das duas instituições estava na oportunidade que ambas ofereceram para que realizássemos essa pesquisa, ambas abriram suas portas e nos receberam. As instituições demonstraram interesse em que o acompanhamento em serviço acontecesse, no entanto, como as creches tinham suas singularidades, nosso acompanhamento foi adaptado a cada uma delas, em seus diferentes modos de funcionamento e nas diferentes necessidades.

As dimensões de cuidados higiênicos nas creches e algumas situações de desamparo em que foram vistos os bebês, além de pontos comuns entre as creches, fizeram pensar a relação com o próprio histórico de nascimento das creches. E como, ainda hoje, podemos encontrar traços dessa história remontados sobre bases aperfeiçoadas, mas que arrastam os mesmos traços.

Destacaremos, então, algumas diferenças entre as creches, a primeira se refere ao modo de funcionamento. Na creche $\mathrm{A}$, não havia período de matrícula para início dos bebês nos berçários, eles eram inseridos a qualquer tempo, ao longo de todo o ano. A implicação desse procedimento era que o número de crianças variava constantemente, sempre em elevação, conforme mostramos nas análises.

Sendo assim, as profissionais recebiam bebês novos o tempo todo e precisavam conhecer, saber os nomes, seus jeitos etc. Além disso, as condições de trabalho delas eram atravessadas por muitas dificuldades, a começar pelo número de bebês para cada profissional. 
Com a creche B, o cenário era outro, havia matrícula para os bebês e o ingresso acontecia somente no mês de fevereiro de cada ano. Também havia um limite para o número de admissões dos bebês, na ocasião o grupo era composto por 13 bebês, acompanhados por 2 professoras mais o apoio de um profissional volante. Sendo assim, havia momentos que encontravam-se as três profissionais no acompanhamento das crianças.

Esse modo de organização e funcionamento favorecia o desenvolvimento de relações de cuidados com os bebês. Havia tempo e espaço para os cuidados de alimentação e higiene, para as brincadeiras, para massagens, para dançar e cantar com os bebês ou, simplesmente, ficar à disposição deles para o que surgisse no contato entre adultos e crianças.

Ressaltamos que as expressões das ligações amorosas com as crianças também apresentavam-se diferente entre as instituições. Na creche $B$, as relações afetivas pareciam mais livres, elas fruíam entre adultos e crianças, eram visíveis e audíveis. Na creche $A$, em um primeiro momento não eram visíveis e, quando surgiram, se mostravam mais restritas, parecia haver um confinamento da afeição a lugares de segredo, a lugares de lembranças.

O interessante é que descobrimos "sequestros amorosos" dos bebês por profissionais em ambas as creches. Esses "sequestros" eram criação de pequenos espaços de relações particularizadas com os bebês. Vistos como brincadeiras pelas profissionais de ambas as creches, porém na creche $B$, o amor circulava abertamente e, na creche $A$, secretamente.

Trataremos agora das semelhanças entre as creches, ambas apresentaram mudanças de profissionais. Nas duas creches, os bebês tiveram suas professoras trocadas ao longo do ano e, os bebês demostraram não apenas perceber as mudanças como, também, mostraram que eram sensíveis as mesmas, apresentando alterações em seus desenvolvimentos. Não se observou nas creches alternativas de transição das profissionais, as mudanças aconteceram de forma repentina, gerando quebra nas relações entre os bebês e as profissionais.

Pensamos que seria interessante que as instituições criassem algumas alternativas para prevenir essas quebras de contato, uma delas, seria manter sempre um profissional de referência para os bebês, o que proporcionaria a apresentação das novidades e facilitaria a inserção dos novos profissionais aos bebês. $\mathrm{O}$ mesmo, para a transição dos bebês para novos ambientes, a possibilidade de junto com os bebês, manejar um profissional conhecido, de forma, a auxiliar a adaptação ao ambiente novo e o contato com outras pessoas.

Outra semelhança entre as creches diz respeito ao estabelecimento de uma relação de cuidados que era marcada por cuidados técnicos e mecânicos, muito carregados de 
automatismo. Com isso, as profissionais perdiam o contato com os bebês, assim sendo, ambas as creches apresentavam necessidades de terem as relações de cuidados entre as profissionais e as crianças facilitadas e apoiadas pelo acompanhamento.

Como isso foi possível?

Pensamos que isso somente se realizou pelo desenvolvimento das relações nas creches. Partimos, a princípio, da aproximação e criação de relações com as profissionais e com os bebês, essa construção facilitou o direcionamento do olhar das profissionais para os bebês e, com isso, vieram as relações de cuidados que se estenderam no percurso.

Tendo em vistas nossos pressupostos, o bebê, ao nascer, não está pronto. Ele tem um longo caminho a percorrer para que as relações pessoais existam como a conhecemos. Como vimos, o bebê começa de uma não diferenciação, de uma condição em que ele ainda não é, ele não existe como alguém discriminado do ambiente de cuidados. Portanto, não é capaz de estabelecer relações com outra pessoa. Para que o bebê alcance essa condição, alcance a possibilidade de existir como alguém diferenciado, em relação com si mesmo e com outros, são necessários cuidados adaptados as necessidades, cuidados que são oferecidos pela mãe, que é o ambiente inicial do bebê.

Através desse ambiente que se adapta e oferece cuidados, aos poucos estabelece-se uma relação, inicialmente com os próprios cuidados que conferem sentido as experiências do bebê em seu próprio corpo. Aos poucos, o bebê vai se estendendo na direção de algo, ele vai em busca de algo ainda não definido. Se esta relação de cuidados se estabelece em uma linha contínua, com regularidade dos cuidados, previsibilidade, uma relação começa se estabelecer pela confiabilidade no ambiente.

As capacidades do bebê se ampliam e os registros das experiências acumuladas capacitam o bebê a guardar algumas memórias e imagens da pessoa que oferece os cuidados, não demora muito, essa pessoa passa ser buscada, ela se tornar alvo do amor do bebê. Temos a constituição de uma ligação com um outro, diferente do bebê, sim, porque, ao mesmo passo que o bebê vai se ligando, ele também vai se diferenciando. Nesse movimento, estão lançadas as bases para o estabelecimento de relações com o outro.

Observamos a construção de relações de cuidados nas creches que se tornaram facilitadoras da continuidade desse processo de desenvolvimento psíquico para os bebês. E essa construção se deu a partir dos mesmos elementos, ou seja, o favorecimento da criação de relações com base na oferta de uma relação de cuidados, que se traduzem pela realização de 
visitas semanais nas creches, a manutenção de contato com as profissionais e os bebês, a propositura de conversas sobre os bebês, o fazer junto, todos esses aspectos realizados com base na regularidade, na continuidade, na manutenção das mesmas formas de relação conforme as capacidades, as alterações dessas relações se davam à medida que as relações na creche também se modificavam e, fundamental, todas realizadas pela mesma pessoa: a pesquisadora.

Podemos dizer que além desses aspectos que constituíram as relações de cuidados nas creches, também houve o apoio às profissionais para que ocupassem a posição de cuidados com os bebês, para isso, também foram necessários manejos de situações nas relações com as profissionais, como pudemos demonstrar. Nesse sentido, podemos pensar que a pesquisadora sustentou as profissionais na criação ou no aperfeiçoamento das relações de cuidados com os bebês.

Desta forma, enfatizamos que os cuidados nascem de uma relação. Os cuidados são entremeados por uma relação à medida que são direcionados a alguém. O cuidado não é passível de ser visto isoladamente, pois acontece, a partir de uma relação com outras pessoas.

Isso adquire importância, na medida que esse tipo de trabalho, feito a partir do acompanhamento em serviço, proporciona um aprimoramento das profissionais e pode ser pensado como um trabalho de formação complementar.

Vimos, que os estudos no campo da educação e cuidados apontam para a importância da formação dos professores para o exercício dos cuidados na creche. Esses estudos entendem, que a superação da dualidade ou dicotomia entre cuidar e educar pode ter sua solução na inserção nos currículos dos cursos de formação acadêmica e em serviço, de conteúdos que tratem da questão dos cuidados nas creches.

Tendo em vista que, o exercício dos cuidados pelas profissionais de educação infantil é tido como algo desprivilegiado, que desvaloriza a condição do professor, é algo que traz demérito profissional. $\mathrm{O}$ que poderia ser alterado por melhor capacitação profissional.

Refletindo sobre esses apontamentos, consideramos importante a inserção de disciplinas e conhecimentos que aprimorem a formação dos profissionais para o exercício da profissão. No entanto, compreendemos, também, que somente o investimento em informações e conteúdos formais não garantem que os cuidados possam ser incorporados e aperfeiçoados no cotidiano do trabalho nas creches.

Entendemos que a realização dos cuidados aos bebês pelos profissionais precisa ser favorecida, nessa direção, pensamos que a formação em acompanhamento em serviço parece 
nos indicar um caminho. Não era objetivo de nossa pesquisa realizar uma formação para os cuidados, no entanto, observamos que nosso acompanhamento favoreceu a realização dos cuidados aos bebês, partindo do desenvolvimento e aperfeiçoamento das relações nas creches.

Somente a formação e realização dos cuidados de forma técnica, não garante uma modificação no modo de olhar para os cuidados. Parece importante, promover o estabelecimento de relações de cuidados. Vimos, que quando as profissionais mudaram a direção do olhar para as crianças, iniciou-se a instalação das relações de cuidados, pois os cuidados deixaram de existir como uma tarefa obrigatória e se tornaram momentos de contato com as crianças, espaço para o relacionamento, trocas, brincadeiras e afeição.

Essas alterações fazem pensar que os cuidados ganharam sentido para as profissionais, a partir do desenvolvimento de relações particularizadas com os bebês. Quando esses cuidados são realizados dentro de uma relação, as profissionais parecem atribuir sentido às tarefas, os cuidados com os bebês parecem ganhar valor.

No contraponto, vimos, que quando os cuidados são realizados somente de forma técnica, instrumental ou, somente do ponto de vista da formação, não se pode afirmar que ele exista. Lembrando que em nossa pesquisa, quatro profissionais possuíam formação superior, sendo três em pedagogia e um em psicologia, elas demonstraram ter conhecimento, saber sobre os cuidados e sobre as crianças, identificavam as necessidades, mas, ainda assim, os cuidados eram frágeis.

O acompanhamento mostrou que esses conhecimentos estavam presentes, ainda assim, os cuidados eram frágeis e se efetivavam em bases de cuidados mecânicos, automáticos, desprovidos de sentido. Dessa forma, os cuidados não tinham valor para as profissionais e nem para os bebês, tendo em vista, que não facilitavam o desenvolvimento deles.

Levando em consideração os resultados desses estudos e nossas reflexões, sugerimos a título de contribuição, que os serviços de educação infantil, especialmente aqueles que cuidam da primeira infância, possam ter um profissional que não pertença ao quadro de funcionários, para realizar o acompanhamento e a formação em serviço com as profissionais, tendo como objetivo, apoiar a posição das profissionais no exercício de suas funções e também promover as relações de cuidados e o desenvolvimento saudável das crianças.

Destacamos, que o profissional não faça parte da estrutura organizacional da instituição, pois esse trabalho requer um distanciamento da imersão que a rotina de trabalho em instituição proporciona. 
Além disso, a condição de não estar imerso no contexto da instituição favorece a independência do profissional e o manejo das situações necessárias (BLEGER, 1984).

Ressaltamos, que nosso acompanhamento em serviço não foi marcado por ações educativas ou pedagógicas, não utilizamos de recursos didáticos como palestras ou cursos, tão pouco, disseminamos conhecimentos técnicos ou teóricos. O leitor não se engane, eles estavam presentes todo o tempo, mas, em nossas relações e ações. Optamos, como apostamos ter mostrado, por outra proposta...

Considerando todos esses pontos, vimos, como esse percurso se construiu no próprio exercício de acompanhamento, como foi sendo pensando, revisado, redirecionado no fazer e no desenvolvimento das relações no ambiente da creche. Seria muita ousadia pensarmos nesse percurso como traços iniciais de um método? Não sabemos, mas, deixamos a questão em aberto.

Pensar em método se fez presente, pois, ao desenvolvermos essa pesquisa, nosso objetivo era analisar as relações de cuidados que existiam nas creches e como elas podem contribuir para o desenvolvimento psíquico dos bebês. No entanto, ao realizar essas ações de pesquisa, pensadas e repensadas como dissemos, vimos a construção de relações entre adultos e crianças e, dessas relações, nasceram relações de cuidados com os bebês.

Nesse sentido, nosso trabalho parece apontar para a criação de relações de cuidados nas creches, elemento que não fazia parte de nossos objetivos, mas que surgiu em nossas análises e resultou como um produto deste trabalho. Verificamos que o cuidar ficou mais leve, divertido e mais simples! E acima de tudo, possível! Observamos a criação de cuidados possíveis...

Por fim, o leitor pode estar se perguntando e quais as contribuições desses cuidados?

Vamos responder essa questão, retomando uma cena interrompida abruptamente...

Amanda continuou no berçário II após a mudança de ciclo. Raimunda continuou sendo educadora daquela sala. No entanto, outras duas educadoras apareceram para compor o quadro de profissionais. Uma que estava de férias e outra que voltou de licença médica.

É importante lembrar que Amanda apresentou como vimos, momentos de retorno aos comportamentos autoestimulatórios, mas destacamos que ela também possuía naquele momento alguns recursos mais desenvolvidos. 
Vimos, que ela estava conseguindo chamar, se locomover, chorava mais alto, assim, também estava Amanda.

Na semana seguinte, a chegada das educadoras "novas", quando cheguei vi as três educadoras e os bebês. Procurei Amanda pela sala e não encontrei...

Reparei que uma das educadoras estava sentada num "puff", próxima a um dos berços, era um cantinho... Ela estava colada e enrolada a um bebê, cantarolando e embalando o bebê. Adivinhem? Sim, era Amanda.

Depois que ela dormiu, conversei com a educadora que contou que ela só dormia assim, e que ela, quem a fazia dormir todos os dias.

Nas semanas seguintes, observei que a educadora que estava de férias, era quem cuidava de Amanda, ela quem trocava, alimentava e brincava com Amanda. Ela demonstrava gostar muito dela.

Em uma tarde, ela trocou Amanda e colocou um vestido curto com uma calcinha toda com rendinha, fofa mesmo, aparecendo. Divertiu-se enfeitando a criança daquele jeito. Também comentou, que achava que a mãe não iria gostar, mas que ela achava uma graça, Amanda com aquela roupinha!

O acompanhamento foi seguindo e em uma tarde, estava brincado com as crianças na sala, quando ouvi um grito muito alto e forte, me assustei e não sabia de quem era. Perguntei à educadora, ela rindo, disse que era Amanda que estava a chamando.

Ela agora conseguia gritar! Uma surpresa!

Amanda foi crescendo e suas capacidades também. Ela começou a andar e junto passou a ir atrás do que queria, fosse a educadora que ela gostava, fosse de brinquedos ou objetos, assim, vieram as disputas com outras crianças, Amanda pegava os brinquedos das mãos de outras crianças. Ela também passou a usar um tampão no olho para corrigir o estrabismo, o que estava melhorando rápido. Quantas diferenças, nem parecia a mesma criança dos inícios.

Ela havia encontrado apoio e cuidados em duas outras educadoras. Uma, que a embalava para dormir e contribuía para ganhar mais corpo, outra que estabelecia uma relação amorosa, o que deslanchou o desenvolvimento dela.

Amanda estava se tornando uma criança ativa, atenta ao que acontecia ao seu redor, ela se mostrava em relação com as educadoras, com a pesquisadora e com as demais crianças. 
Em outubro, quando Amanda completou um ano, em uma conversa com a mãe, esta contou que iriam se mudar para outro país, ainda, não sabia a data correta, mas estavam resolvendo alguns detalhes.

Em novembro, em uma das visitas, estava trabalhando em conjunto com Raimunda, uma tarde em que o clima entre ela e as crianças, estava muito tenso, pois ela estava trabalhando sozinha, porque as duas educadoras haviam faltado.

Eu estava ao lado de fora da cerca de madeira que dividia o berçário da área de troca, Amanda e outras crianças estavam na cerca brincando comigo, elas traziam alguns brinquedos para mim ou jogavam para que eu pegasse e devolvesse, aquele jogo que criança gosta...

Amanda gostava de brincar com as panelinhas, então, ela trouxe algumas e me deu, fiquei brincando com ela pela da cerca. Em um dado momento, Amanda pegou na minha mão e me pихои em direção ao portão. Entendi que era para entrar. Entrei, ela continuou me levando pela mão, até um cantinho da sala onde havia panelinhas, olhou para mim, sorriu, sentou no chão, sentei com ela e brincamos por algum tempo juntas. Na hora de ir embora, expliquei para ela que precisava ir, dei um beijo e sai rumo a cerca, antes de deixar a sala, acenei dando "tchau”, Amanda me olhando, também acenou! Foi a última vez que vi Amanda na creche... 


\section{REFERÊNCIAS}

ALVES, R. O preparo do educador. In: Brandão, C.R. (org.) O Educador: vida e morte. Rio de Janeiro: Edições Graal, 1982.

BECKER, S.M da S., BERNARDI, D.; MARTINS, G.D.F. Práticas e crenças de educadoras de berçário sobre cuidado. Psicologia em Estudo, Maringá, v.18, n.3, p. 551-560, jul./set. 2013.

BLEGER, J. Psico-Higiene e Psicologia Institucional. São Paulo: Ed. ARTMED, 2003.

BÓGUS, M.C, et al. Cuidados oferecidos pelas creches: percepções de mães e educadoras. Revista de Nutrição, Campinas, v. 20, n.5, p. 499-514, set/out, 2007.

BRANDÃO, C.R. REFLETIR, DISCUTIR, PROPOR: As dimensões de militância intelectual que há no Educador. In: Brandão, C.R. (org.) O Educador: vida e morte. Rio de Janeiro: Edições Graal, 1982.

CERISARA, A.B. Educar e cuidar: por onde anda a educação infantil? PERSPECTIVA. Florianópolis, v.17, n. Especial, p.11-21, jul./dez.1999.

CORRÊA, B.C. Considerações sobre qualidade na educação infantil. Cadernos de Pesquisa, n.119, p.85-112, julho/2003.

CHAUÍ, M.S. O que é ser educador hoje? Da arte à ciência: a morte do educador. In: Brandão, C.R. (org.) O Educador: vida e morte. Rio de Janeiro: Edições Graal, 1982.

CRUZ, S.H.V. Reflexões acerca da formação do educador infantil. Cad. Pesq., São Paulo, n.97, p.79-89, maio 1996.

DETHIVILlE, L. Donald W. Winnicott uma nova abordagem. Campinas, São Paulo: Armazém do Ipê, 2011.

DIAS, E. O. A teoria do Amadurecimento de D.W.Winnicott. Rio de Janeiro, Imago, 2003.

DIAS, E. O. Sobre a confiabilidade e outros estudos. São Paulo, DWW Editorial, 2011. 
Etimologia de Educar. Disponível em: <:https://pt.wiktionary.org/wiki/educar->. Acesso em: 19 fev. 2016.

FARIAS, M. Infância e educação no Brasil nascente. In: Vasconcellos, V.M.R de (Org.). Educação da infância: história e política. $2^{\text {a }}$.edicão, Niterói: Editora da UFF, 2013.

FERREIRA, A.B.H. Novo Aurélio Século XXI: o dicionário da língua portuguesa. 3.ed. Rio de Janeiro: Nova Fronteira, 1999.

FREUD, S. (1914) Sobre o Narcisismo: uma introdução. Trad. sob a direção de Jayme Salomão. Rio de Janeiro: Imago,1996. (Edição Standard Brasileira das Obras Completas de Sigmund Freud, Vol. XIV. p.77-108).

FREUD, S. (1915) Os instintos e suas vicissitudes. Trad. sob a direção de Jayme Salomão. Rio de Janeiro: Imago,1996. (Edição Standard Brasileira das Obras Completas de Sigmund Freud, Vol. XIV, p. 123-144).

GEIS, R. M. Criar ou educar crianças? Estudo das representações de mães e educadoras sobre o papel da creche. Tese de Doutorado em Psicologia Escolar e do Desenvolvimento Humano - Instituto de Psicologia, Universidade de São Paulo, São Paulo, 1994

GOMES, K. Um novo paradigma da psicologia para pensar a educação infantil. Revista Múltiplas Leituras, v.2, n.1, p.153-166, jan./jun. 2009

GUIRADO, M. (1980). A criança e a FEBEM. São Paulo: Editora Perspectiva S.A.

GUIRADO, M. A análise institucional do discurso como analítica da subjetividade. São Paulo: Annablume, 2010.

HAMMOUD, T.C. Sobre uma concepção de manejo na clínica winnicottiana. In: Winnicott eprints, vol.7, n. 2, p.1-14, São Paulo, 2012.

JUNIOR, Carlos A. P. Sobre a importância do corpo para a continuidade do ser. Revista MalEstar e Subjetividade. Fortaleza, Vol. VIII - N. 4, p. 927-958, 2008.

KRAMER, S. A política do pré-escolar no Brasil: a arte do disfarce. Rio de Janeiro: Achiamé, 1984. 
KUHLMANN JUNIOR, M. Infância e Educação Infantil: uma abordagem histórica. Porto Alegre: Mediação, 1998.

KUPFER, M.C.M. et al. Apresentação e debate em torno da Pesquisa Multicêntrica de Indicadores Clínicos de Risco para o Desenvolvimento Infantil. In: LERNER, R.; KUPFER, M.C.M.(Orgs.) Psicanálise com crianças: clínica e pesquisa. São Paulo: Escuta, 2008.

KUPFER, M.C.M.; BERNARDINO, L.M.F.; MARIOTTO, R.M.M., (Orgs.) Metodologia IRDI: uma ação de prevenção na primeira infância. In: Psicanálise e ações de prevenção na primeira infância. São Paulo: Escuta/Fapesp, 2012.

KUPFER, M.C.M.; BERNARDINO, L.M.F.; MARIOTTO, R.M.M. (Orgs.) De bebê a sujeito: A metodologia IRDI nas creches. São Paulo: Escuta/Fapesp, 2014.

LEJARRAGA, A.L. O amor em Winnicott. Rio de Janeiro: Garamond, 2012.

LESCOVAR, G.Z. As consultas terapêuticas e a psicanálise de D.W.Winnicott. Revista Estudos de Psicologia, PUC Campinas, v.21, n. 2, p.43-61, mai/agosto, 2004.

LINHARES, M.B.M. Desenvolvimento de bebês pré-termo no primeiro ano de vida. Paidéia, v.13, n. 25, p. 59-72, 2003

LINS, M.I.A. Consultas terapêuticas. São Paulo: Casa do Psicólogo, 2006.

MACHADO, N.P. et al. Investigação do reconhecimento do próprio nome de bebês de 4 a 5 meses: estudo piloto. Rev. CEFAC., v.15, n. 5, p.1080-1087, Set/Out, 2013

MARCÍLIO, M.L. A roda dos expostos e a criança abandonada na História do Brasil -17261950. In: FREITAS, M.C. História social da infância no Brasil. São Paulo: Cortez, 2006.

MARCÍLIO, M.L. A história social da criança abandonada. São Paulo: Hucitec, 2006.

MARIOTTO, R. M. M. Atender, cuidar e prevenir: a creche, a educação e a psicanálise. Estilos da Clínica, São Paulo, v.8 n.15, jun, 2003.

MARIOTTO, R. M. M. Cuidar, Educar e Prevenir: as funções da creche na subjetividade de bebês. São Paulo: Escuta, 2009. 
MENEZES, J.C.P.; MORATTI, P. Metodologia IRDI e a sustentação da relação professorbebê: holding do holding. In: Kupfer, M.C.M, Bernardino, L.M.F., Mariotto, R.M.M. (Orgs.). De bebê a sujeito: A Metodologia IRDI nas creches. São Paulo, Escuta/Fapesp, 2014.

MERISSE, A. A infância e seus lugares: um estudo sobre as concepções de mães e funcionárias de creche. Tese de Doutorado em Psicologia Escolar e do Desenvolvimento Humano - Instituto de Psicologia, Universidade de São Paulo, São Paulo, 1996.

MERISSE, A. Origens das instituições de atendimento à criança: o caso das creches. In: MERISSE, A., JUSTO, J.S., ROCHA, L.C.; VASCONCELOS, M.S. (Orgs.) Lugares da infância: reflexões sobre a história da criança na fábrica, creche e orfanato. São Paulo: Arte \& Ciência, 1997.

MORATTI, P.; LIMA, K. M. A integração psicossomática na constituição psíquica de bebês: os cuidados na creche. In: KUPFER, M.C.M; BERNARDINO, L.M.F.; MARIOTTO, R.R.M. (Orgs.) De bebê a sujeito: a Metodologia IRDI nas creches. São Paulo: Editora Escuta/Fapesp, 2014.

PARDAL, M.V.C. O cuidado com as crianças pequenas no Brasil escravista. In: Vasconcellos, V.M.R de (Org.). Educação da infância: história e política. $2^{a}$.edicão, Niterói: Editora da UFF, 2013.

RAPOPORT, A.; PICCININI, César A. A escolha do cuidado alternativo para o bebê e a criança pequena. Estudos de Psicologia. Universidade Federal do Rio Grande do Sul, v.9, n.3, p. 497 503, 2004.

REIS, A.C. A institucionalização da infância no Brasil republicano. In: Vasconcellos, V.M.R de (Org.). Educação da infância: história e política. $2^{a}$.edicão, Niterói: Editora da UFF, 2013.

RIZZINI, I; RIZZINI, I. A institucionalização de crianças no Brasil: percurso histórico e desafios do presente. Rio de Janeiro: Ed. PUC-Rio; São Paulo: Loyola, 2004.

RIZZINI, I. O século perdido: raízes históricas das políticas públicas para infância no Brasil. 2 ${ }^{\text {a }}$.ed.; São Paulo: Cortez, 2008.

RIZZO, G. Creche: organização, currículo, montagem e funcionamento. Rio de Janeiro: Bertrand Brasil, 2000.

ROSEMBERG, F. A LBA, o Projeto Casulo e a Doutrina de Segurança Nacional. In: FREITAS, M.C. História Social da Infância no Brasil. São Paulo: Cortez, 2006. 
SANTOS, F.M.S.; MOURA, M.L.S. A relação mãe-bebê e o processo de entrada na creche: esboços de uma perspectiva sociocultural. Psicol. cienc. prof., Brasília, v. 22, n. 2, jun, 2002. Disponível em <http://pepsic.bvsalud.org/scielo.php?script=sci_arttext\&pid=S141498932002000200011\&lng=pt\&nrm=iso >. Acesso em: 06 out. 2010.

SILVA, L.B.M. A produção do conceito de narcisismo em Freud: uma análise institucional do discurso. Dissertação de Mestrado em Psicologia Escolar e do Desenvolvimento Humano Instituto de Psicologia, Universidade de São Paulo, São Paulo, 2014.

SILVA, M.G. Testemunho sobre João Paulo. In: Jerusalinsky, A. (org). Dossiê Autismo. São Paulo: Instituto Langage, 2015.

SPITZ, R.A. O desenvolvimento emocional do recém-nascido. Rio de Janeiro: Livraria Pioneira Editora, 1960.

SPITZ, R.A. O não e o sim: a gênese da comunicação humana. São Paulo: Martins Fontes, 1978.

SPITZ, R.A. A formação do ego: uma teoria genética e de campo. São Paulo: Martins Fontes, 1979.

SPITZ, R.A. O primeiro ano de vida: um estudo psicanalítico do desenvolvimento normal e anômalo das relações objetais. $3^{a}$ edição. São Paulo: Martins Fontes, 1983.

VASCONCELLOS, V.M.R de (Org.). Educação da infância: história e política. $2^{\mathrm{a}}$.edicão, Niterói: Editora da UFF, 2013.

VERÍSSIMO, M.D.L.Ó.R.; FONSECA, R.M.G.S. Funções da creche segundo suas trabalhadoras: situando o cuidado da criança no contexto educativo. Rev. Esc. Enferm USP, v. 37, n.2, p. 25-34, 2003.

VITTA, F.C.; EMMEL, M.L.G. A dualidade cuidado x educação no cotidiano do berçário. Paidéia, v.14, n.28, p. 177-189, 2004.

WINNICOTT, D.W. A criança e seu mundo. $2^{\text {a }}$.ed. Rio de Janeiro: Zahar Editores, 1971. mundo. $2^{\text {a }}$.ed. Rio de Janeiro: Zahar Editores, 1971. 
Conheça o seu Filhinho. In: Winnicott, D.W. A Criança e seu mundo. 2a.ed. Rio de Janeiro: Zahar Editores, 1971.

Amamentação. In: Winnicott, D.W. A Criança e seu mundo. $2^{a}$.ed. Rio de Janeiro: Zahar Editores, 1971.

O Bebê como Organização em Marcha. In: Winnicott, D.W. A Criança e seu mundo. $2^{\text {a }}$.ed. Rio de Janeiro: Zahar Editores, 1971.

Mais Ideias Sobre Bebês como Pessoas. In: Winnicott, D.W. A Criança e seu mundo. $2^{\text {a }}$.ed. Rio de Janeiro: Zahar Editores, 1971.

(1975). O brincar e a Realidade. Rio de Janeiro: Imago, 1975.

(1969). O uso de um objeto e relacionamento através de identificações.

In: Winnicott, D.W. O brincar e a Realidade. Rio de Janeiro: Imago, 1975.

(1969). A localização da experiência cultural. In: Winnicott, D.W O brincar e a Realidade. Rio de Janeiro: Imago, 1975.

(1960). Teoria do relacionamento paterno-infantil. In: Winnicott, D.W. O ambiente e os processos de maturação. Porto Alegre: Artmed, 1983.

(1962). A integração do ego no desenvolvimento da criança. In: Winnicott, D.W O ambiente e os processos de maturação. Porto Alegre: Artmed, 1983.

(1962) Provisão para a criança na saúde e na crise. In: Winnicott, D.W O ambiente e os processos de maturação. Porto Alegre: Artmed, 1983.

(1959-1964) Classificação: existe uma contribuição psicanalítica à classificação psiquiátrica? In: Winnicott, D.W. O ambiente e os processos de maturação. Porto Alegre: Artmed, 1983.

(1963) Distúrbios psiquiátricos e processos de maturação infantil. In: Winnicott, D.W. O ambiente e os processos de maturação. Porto Alegre: Artmed, 1983.

Natureza Humana. Rio de Janeiro, Imago, 1990. 
(1961) Observações Adicionais sobre a Teoria do Relacionamento

Parento-Filial. In: Winnicott, D.W. Explorações Psicanalíticas: D. W. Winnicott. Porto Alegre: Artmed Editora, 1994.

(1969) A Experiência Mãe-Bebê de Mutualidade. In: Winnicott, D.W.

Explorações Psicanalíticas: D. W. Winnicott. Porto Alegre: Artmed Editora, 1994.

(1969) Fisioterapia e Relações Humanas. In: Winnicott, D.W.

Explorações Psicanalíticas: D. W. Winnicott. Porto Alegre: Artmed Editora, 1994.

. (1970) Sobre as Bases para o self no Corpo. In: Winnicott, D.W.

Explorações Psicanalíticas: D. W. Winnicott. Porto Alegre: Artmed Editora, 1994.

(1936) Higiene mental da criança pré-escolar. In: Shepherd, R., Johns, J.,

Robinson, H.T. Pensando sobre crianças. Porto Alegre: Artes Médicas, 1997.

(1936) A professora, os pais e o médico. In: Shepherd, R., Johns, J., Robinson, H.T. Pensando sobre crianças. Porto Alegre: Artes Médicas, 1997.

(1969) A construção da confiança. In: Winnicott, D.W. Conversando com os Pais. São Paulo: Martins Fontes, 1999.

(1949) Desenvolvimento Emocional Primitivo. In: Winnicott, D.W. Da

Pediatria à Psicanálise: Obras Escolhidas. Rio de Janeiro: Imago, 2000.

(1949) A Mente e sua Relação com o Psicossoma. In: Winnicott, D.W.

In: Pediatria à Psicanálise: Obras Escolhidas. Rio de Janeiro: Imago, 2000.

(1950) A Agressividade em Relação ao Desenvolvimento Emocional. In:

Winnicott, D.W. In: Pediatria à Psicanálise: Obras Escolhidas. Rio de Janeiro: Imago, 2000.

(1952) Ansiedade Associada à Insegurança. In: Winnicott, D.W. In:

Pediatria à Psicanálise: Obras Escolhidas. Rio de Janeiro: Imago, 2000.

. (1952) Psicoses e Cuidados Maternos. In: Winnicott, D.W. Da Pediatria

à Psicanálise: Obras Escolhidas. Rio de Janeiro: Imago, 2000. 
(1956) A Preocupação Materna Primária. In: Winnicott, D.W. In: Da Pediatria à Psicanálise: Obras Escolhidas. Rio de Janeiro: Imago, 2000.

O primeiro ano de vida. Concepções modernas do desenvolvimento emocional. In: Winnicott, D.W. A família e o desenvolvimento individual. $3^{\mathrm{a}}$ ed. São Paulo: Martins Fontes, 2005.

O relacionamento inicial entre uma mãe e seu bebê. In: Winnicott, D.W.

A família e o desenvolvimento individual. $3^{\text {a }}$ ed. São Paulo: Martins Fontes, 2005.

Influências de grupo e a criança desajustada. In: Winnicott, D.W. A família e o desenvolvimento individual. $3^{\mathrm{a}}$ ed. São Paulo: Martins Fontes, 2005.

Crescimento e desenvolvimento na fase imatura. In: Winnicott, D.W. A família e o desenvolvimento individual. $3^{a}$.ed. São Paulo: Martins Fontes, 2005.

Os bebês e suas mães. $3^{\text {a }}$.ed. São Paulo: Martins Fontes, 2006. 